CAMILA FERNANDA DE PAULA OLIVEIRA

\title{
OBTENÇÃO E CARACTERIZAÇÃO DE AMIDO TERMOPLÁSTICO E DE SUAS MISTURAS COM POLIPROPILENO
}

Tese apresentada à Escola Politécnica da Universidade de São Paulo para obtenção do título de Doutor em Engenharia.

SÃO PAULO

2015 
CAMILA FERNANDA DE PAULA OLIVEIRA

\section{OBTENÇÃO E CARACTERIZAÇÃO DE AMIDO TERMOPLÁSTICO E DE SUAS MISTURAS COM POLIPROPILENO}

Tese apresentada à Escola Politécnica da Universidade de São Paulo para obtenção do título de Doutor em Engenharia.

Área de Concentração:

Engenharia de Materiais

Orientadora:

Prof. Dra. Nicole Raymonde Demarquette

Co-Orientadora:

Prof. Dra. Ticiane Sanches Valera

\section{SÃO PAULO}

2015 
Este exemplar foi revisado e corrigido em relação à versão original, sob

responsabilidade única do autor e com a anuência de seu orientador.

Assinatura do autor:

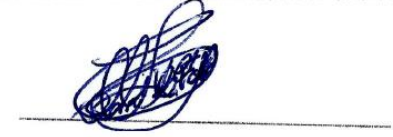

Assinatura do orientador:

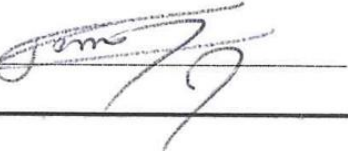

Catalogação-na-publicação

Oliveira, Camila Fernanda de Paula

OBTENÇÃO E CARACTERIZAÇÃO DE AMIDO TERMOPLÁSTICO E DE SUAS MISTURAS COM POLIPROPILENO / C. F. P. Oliveira -- versão corr. -São Paulo, 2015.

$197 \mathrm{p}$.

Tese (Doutorado) - Escola Politécnica da Universidade de São Paulo. Departamento de Engenharia Metalúrgica e de Materiais. 
"De alguma forma, eu não posso acreditar que existam alturas que não podem ser escaladas por um homem que conhece os segredos de fazer sonhos se tornarem realidade. Este segredo especial, parece-me, pode ser resumido em quatro "c"s. Eles são: curiosidade, confiança, coragem e constância ."

Harriet Beecher Stowe 
Aos meus pais, que me ensinaram valores essenciais para a vida.

As minhas irmãs que me apoiaram em todos os momentos, não me deixando desistir.

Muito obrigada por fazerem parte da minha vida. 


\section{AGRADECIMENTOS}

Este trabalho durou alguns anos, nestes anos eu realmente vivi essa pesquisa e passei por todos os tipos de sentimentos: tristeza, alegria, desânimo, empolgação. Confesso até que pensei em desistir várias vezes. Mas, chegar ao final me traz uma emoção única, pois é um sonho sendo realizado. No entanto, apesar de no trabalho constar apenas o meu nome, ele jamais teria acontecido sem a ajuda, auxílio, colo, broncas, "brigas", conversas de diversas pessoas as quais eu gostaria e preciso agradecer.

Em primeiro lugar a Deus, que soube em sua infinita sabedoria me conduzir em cada passo, estando ao meu lado e muitas vezes até me carregando no colo. Obrigada por me conceder força, sabedoria, coragem, equilíbrio e discernimento em tudo que vivencio. Agradeço pela vida e todas as bênçãos que me tem concedido. Obrigada Pai por estar perto de mim!!!

Aos meus pais, Edgard e Ângela que sempre me apoiaram, auxiliaram e me incentivaram a nunca desistir. As minhas irmãs Carla e Carina pelo amor, carinho e compreensão, por me divertirem e claro me irritarem também. Sem eles nada disso seria possível. Obrigada por compreenderem minha falta de tempo pra tudo. Algumas pessoas dizem que nós não escolhemos nossa família, mas eu escolheria cada um de vocês. Vocês são minha base, meu alicerce, meus amores.

Ao Bruno Luiz por aturar meu "bom humor", pelos finais de semana no laboratório, pelas noites e pelos domingos em frente ao computador. Obrigada por estar ao meu lado nos momentos mais difíceis e por NUNCA ter me deixado desistir.

À minha filha linda Sushi, meu bebe que me diverte e me alegra todos os dias. Ela me dá carinho e o amor mais puro sem exigir nada em troca.

Aos meus cunhados Edson e Gustavo por me aguentarem, o que eu confesso que não foi nada fácil.

Aos meus avós Edward e Odete, que tenho certeza que olham e intercedem por mim junto ao Pai. Amo vocês e a saudade é imensa.

A Profa. Dra. Nicole Raymonde Demarquette, que me orientou ao longo desses anos, no mestrado e nesta pesquisa. Obrigada pela confiança, pelas broncas, pelas ideias, discussões, pelos auxílios e puxões de orelha, e claro, por todos os 
ensinamentos, afinal eles foram muito além do mundo da pesquisa. Muito Obrigada por tudo!!!

A Profa. Dra. Ticiane Sanches Valera que me co-orientou, que esteve sempre perto para me auxiliar, ajudar e por nunca ter me deixado na mão. Obrigada pela confiança, pelas conversas, pela paciência imensa, pelas ideias, discussões de resultados e por me acalmar no meio das turbulências que ocorreram. Obrigada pelos ensinamentos sobre como fazer uma pesquisa e também pelos ensinamentos sobre a vida. Me faltam palavras para agradecer a senhora por tudo!!!!

Ao Prof. Guilhermino Fechine por ter me ensinado e ainda me ensinar muito, pela paciência, por ter me dado base e por ser o "culpado" por eu amar fazer pesquisa e em especial trabalhar com polímeros.

Aos meus amigos do Laboratório de Processamento e Reologia de Polímeros, digo amigos pois eles não são apenas meus colegas de "trabalho", são meus amigos que me apoiam, me ouvem, me criticam, me fazem crescer e aprender cada dia mais: Douglas (obrigada por me ensinar a usar o FTIR e pelas análises), Natália Massaro (obrigada pelos ensaios térmicos), Fernanda (obrigada por ser uma flor), Carla (obrigada pela paciência), Eder (obrigada pelas discussões), Kléber (obrigada pelos ensinamentos na injetora), Suelen, Anita, Letícia (obrigada pelas “ajudinhas" e pelas discussões), Natália Nobre Fidalgo (você foi sensacional), Lucas Moura (obrigada pela ajuda e pelas conversas), Isadora Abduch.

Aos meus amigos que não estão mais no Laboratório, mas que me ajudaram muito e ainda me auxiliam sempre com ideias, cafés, conversas ou apenas um colo: Adriana, Cássia, Danilo, Fábio, Patrícia, Pedro e Marcio.

Ao pessoal dos outros laboratórios que sempre me acompanharam e se tornaram meus amigos e confidentes: Deise, Lorena, Joice, Rafael.

Aos funcionários do departamento de Engenharia Metalúrgica e de Materiais por toda a assistência prestada, em especial: Danilo (você sempre me salva, muito obrigada), Rubens (sempre resolvendo meus "probleminhas", muito obrigada), Lívio, Vera, Ivo, Patrícia, Suelen (salvadora dos alunos de pós).

Ao Verissimo por toda paciência e pela realização das análises de MEV.

Ao Dr. Flávio da geologia da USP pelos ensaios de DRX. 
Ao Luiz e ao Cabral do Mackenzie pelo auxílio na utilização da calandra e dos ensaios de impacto.

Ao Rogério e ao Arnaldo da UFABC pelo auxílio nos ensaios de tração e conformação de alguns corpos de prova.

A Ingredion pela doação do amido de milho.

A Eng Plast pela doação do resíduo de PP.

À FAPESP, à CAPES a ao CNPQ pelo apoio financeiro.

Ao João Avanzi e a Fátima Avanzi que aguentaram meu "bom humor" durante meus períodos de estresse, pelas conversas, lanchinhos, por tudo!!!!.

A todos os meus tios, tias, primos e primas (Família de Paula e Família Oliveira) pelo apoio e pela torcida. Cada um de vocês é único e especial para mim.

Aos meus amigos Camila, Leice, Marcus, Danilo, Vitor, Fê, Dani's, Joy. Sei que vocês estão vibrando tanto quanto eu, ou até mais, por essa etapa. Vocês são sensacionais!!!!!

Á todos os brasileiros que pagam seus impostos, pois graças a vocês consegui a obtenção da bolsa de doutorado e pude me dedicar a esta pesquisa.

Á todos que direta ou indiretamente contribuíram para a realização deste trabalho.

Muito obrigada a todos vocês!!!! 


\section{RESUMO}

Este trabalho está dividido em: obtenção e caracterização de amido termoplástico (TPS); estudo do envelhecimento do TPS e blendas de PP/TPS. O estudo do TPS, foi realizado utilizando amido de milho, $30 \%$ em massa de glicerol e outros componentes que variam entre as amostras. Primeiramente foi realizado um planejamento estatístico para obter a composição ótima de TPS. Foram escolhidos cinco parâmetros de entrada: 2 de composição (umidade e teor de ácido cítrico) e 3 de processamento (temperatura, velocidade dos rotores e tempo), visando obter um TPS com propriedades térmicas e mecânicas superiores. De acordo com os resultados de infravermelho, termogravimetria, microscopia ótica (MO) e microscopia eletrônica de varredura (MEV) foram escolhidas 2 composições. Estas foram calandradas e confeccionadas para obtenção dos corpos de prova de tração. Os resultados dos ensaios mecânicos mostraram que amostras com teor de ácido cítrico de aproximadamente $2 \%$ em massa apresentam os maiores valores de módulo de elasticidade e resistência à tração. Com estes resultados foram realizadas novas composições com outros ácidos carboxílicos: adípico, málico e tartárico e amostras sem ácidos. As curvas de torque indicaram que as amostras sem ácido carboxílico e com ácido adípico perdem água durante o processamento. Analisando os resultados verifica-se que o TPS com os ácidos málico e tartárico apresentam melhores propriedades mecânicas e térmicas. Também foi analisado o envelhecimento, e notou-se que com o tempo as amostras tendem a perder plastificante, modificando suas propriedades mecânicas e sua cristalinidade. Entretanto, durante o intervalo de um ano, as amostras de TPS com ácido málico e tartárico não sofreram perda significativa de plastificante. Por último, foram obtidas blendas de PP reciclado com TPS nas composições 50/50, 60/40 e 70/30 em massa, respectivamente, com e sem adição de ácidos: cítrico, málico e tartárico e anidrido maleico. As amostras foram caracterizadas por FTIR, DRX, reometria capilar, MEV e por teste de resistência à tração. Micrografias obtidas por MEV indicaram que todas as composições estudadas possuem morfologia predominantemente co-contínua. A presença dos ácidos, geralmente, reduz os valores das propriedades mecânicas da blenda de PP com TPS e a adição de PP-g-MA é mais efetiva nas blendas sem adição de ácido. Ao analisar o envelhecimento das blendas com adição de ácidos tartárico e málico, notou-se que as propriedades mecânicas não foram alteradas em função do tempo de estocagem.

Palavras-Chave: Amido termoplástico (TPS). Ácidos carboxílicos. Envelhecimento do TPS. Blendas. 


\begin{abstract}
This work is divided in four parts: obtention and characterization of thermoplastic starch (TPS), study of TPS ageing, and characterization of PP/TPS blends. This study used TPS with cornstarch, glycerol (30 wt.\%) and other components. First of all, a statistic study about thermoplastic starch preparation methods was performed in order to obtain the best TPS composition. Five parameters were evaluated: the starch water content, citric acid concentration, and three process parameters: temperature, time and rotor speed. According to infrared, thermogravimetry, optical microscopy, and scanning electron microscopy results, we have chosen two compositions to be mechanically tested. The mechanical tests required the samples to be calendered and cut with knife. The results of the mechanical tests showed that samples containing $2 \mathrm{wt} . \%$ of citric acid had the highest Young modulus and tensile strength values. Based on these results, new compositions were prepared with other carboxylic acids, such as adipic, malic and tartaric acids, as well as pure samples. The torque curves showed that the samples without carboxylic and adipic acid loose water during the processing. Analyzing the results, it is possible to see that TPS with malic and tartaric acids have better mechanical and thermal properties. Ageing was also analyzed and it was noted that the samples tend to loose plasticizer, altering their mechanical properties and crystallinity with time. However, during the one-year period, TPS samples with malic and tartaric acid suffered no significant plasticizer loss. Finally, recycled PP blends were obtained with the following compositions of PP/TPS: 50/50,60/40, and 70/30. To these blends, some acids were added, such as citric, malic and tartaric, and maleic anhydride. Their properties were compared to the ones for pure blend. The samples were characterized by FTIR, XRD, capillary rheometry, SEM, and for tensile strength. SEM micrographs showed that all studied blends have predominantely co-continuous morphology. Usually, the presence of the acid reduces the mechanical property values of the PP/TPS blends. The addition of PP-g-MA is more effective in blends without acids. By analyzing the ageing of the blends with malic and tartaric acid it was noted that the mechanical properties were not changed as a function of the storage time.
\end{abstract}

Keywords: Thermoplastic Starch. Carboxylic Acids. TPS ageing. Blends. 


\section{LISTA DE FIGURAS}

Figura 1 - Características de alguns amidos comerciais. 33

Figura 2 - Representação da Estrutura Química (a) da Amilose e (b) da Amilopectina. 35

Figura 3 - Classificação das cadeias de amilopectina em tipo A, B e C. 35

Figura 4 - Figuras esquemáticas da (a) estrutura tridimensional em dupla hélice dos segmentos lineares da amilopectina e da (b) estrutura em cachos da amilopectina. 36 Figura 5 - Estrutura cristalina da amilopectina: (a) monoclínica e (b) hexagonal. Os círculos pretos representam as moléculas de água constituintes da estrutura cristalina. 38 Figura 6 - (a) MEV e estrutura esquemática do crescimento em anéis das lamelas cristalinas e amorfas na amilopectina. (b) MET de amido de milho ceroso (alto teor de amilopectina).. 39 Figura 7 - Estrutura em grânulos do amido de (a) milho nativo, (b) trigo e (c) batata, (d) tapioca, (e) feijão e (f) arroz obtidas por MEV. 40 Figura 8 - Microscopia óptica com luz polarizada mostrando o fenômeno cruz de malta para amido com alta amilose e para amido de feijão (figura inserida no canto inferior esquerdo).

Figura 9 - Hidrólise do amido por ação enzimática da amilase.

Figura 10 - Variação típica do torque em função do tempo de mistura, em um misturador de câmara interna, para o TPS.

Figura 11 - Representação esquemática das fases de transição do amido durante o processamento térmico.

Figura 12 - Representação da estrutura química do glicerol.

Figura 13 - Representação da estrutura química do anidrido maleico.

Figura 14 - Representação da estrutura química do ácido cítrico.

Figura 15 - Reações que podem ocorrer durante o aquecimento entre o amido e o ácido cítrico. 56

Figura 16 - Reação de Hidrólise. 57

Figura 17 - Glicosidação do amido. 58

Figura 18 - Reação de Esterificação entre amido e ácido cítrico. 59

Figura 19 - Reação ácido cítrico com amido e glicerol - Hidrólise ácida ou Acidólise. 60 
Figura 20 - Representação da estrutura química do ácido adípico.

Figura 21 - Representação da estrutura química do ácido málico.

Figura 22 - Representação da estrutura química do ácido tartárico.

Figura 23 - Escolha dos parâmetros para o planejamento $3^{3-1}$ fatorial. ................................68

Figura 24 - Curva de termogravimetria do amido seco por $48 \mathrm{~h}$ a $110^{\circ} \mathrm{C}$. ............................ 71

Figura 25 - Mistura mecânica das amostras de TPS.......................................................... 71

Figura 26 - Mistura selada, pronta para ser colocada na estufa. ......................................... 72

Figura 27-Processo de calandragem e moldagem por compressão amostra após ser retirada da câmara de mistura (a), amostra após o processo de calandragem(b) e corpo de prova após ser moldado por compressão

Figura 28 - Direção das amostras quando processadas na calandra utilizdas nos ensaios de tração.

Figura 29-Curvas de torque obtidas durante o processamento das misturas em câmara fechada acoplada ao reômetro de torque (a) sem ácido cítrico e (b) com ácido cítrico. Figura 30 - Curvas de torque obtidas até 4 minutos de processamento, das misturas 2, 3, 4, 6, 7 e 8 em câmara fechada acoplada ao reômetro de torque.

Figura 31- Gráfico do torque final em função das composições de ácido e umidade normalizadas, processadas à temperatura de $150^{\circ} \mathrm{C}$, por 8 minutos e a $100 \mathrm{rpm}$. 82 Figura 32 - Espectros FTIR das amostras de amido e ácido cítrico. 83

Figura 33- Espectro FTIR das amostras de TPS preparadas. 84

Figura 34- Gráfico da relação entre os picos dos espectros de infravermelho em função das composições de ácido e umidade normalizadas, processadas à temperatura de 125드, por 8 minutos e a $100 \mathrm{rpm}$

Figura 35-Curvas de DTG para as amostras da mistura 1.

Figura 36- Gráfico da temperatura de degradação em função das composições de ácido e umidade normalizadas processadas à temperatura de $150^{\circ} \mathrm{C}$, por 8 minutos e a $100 \mathrm{rpm}$....88 Figura 37-MEV com $1000 \times$ de aumento das amostras (a) 20 (150C e 10\% umidade) e (b) 24 (125C e 20\% umidade), ambas com 4\% de ácido cítrico e processadas por 15 min a 100rpm.

Figura 38 - Curvas de Torque em função do tempo para as amostras 7, 7mod, AC2 e AC3...92 
Figura 39 - Espectros FTIR para as amostras 7, 7mod, AC2 e AC3.

Figura 40 - Curvas de (a) TG e (b) DTG para as amostras 7, 7mod, AC2 e AC3.....................94

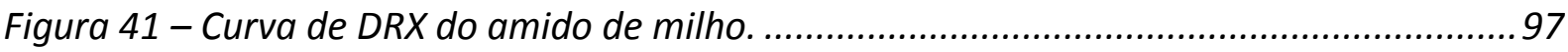

Figura 42 - Curvas de DRX para as amostras 7 e $7 \bmod (a)$ e AC2 e AC3 (b)..........................98

Figura 43 - Imagens de MEV das amostras 7(a), $7 \bmod (b), A C 2(c)$ e $A C 3(d)$....................... 101

Figura 44 - Curvas de Torque em função do tempo para as amostras com Ácido Adípico,

Ácido Cítrico, Ácido Málico e Ácido Tartárico....................................................................... 104

Figura 45 - Espectros FTIR das amostras de TPS com e sem os ácidos carboxílicos..............105

Figura 46 - Análise termogravimétrica: (a) TG e (b) DTG dos ácidos carboxílicos. ...............106

Figura 47 - Curvas DTG para as amostras de TPS sem ácido (a), com ácido adípico (b), com ácido cítrico(c), com ácido málico (d) e com ácido tartárico (e)........................................106

Figura 48 - Curvas DTG para o amido (a) e para as amostras de TPS (b)............................ 107

Figura 49 - Curvas de DRX das amostras com 20 e 30\% de água, sem ácido carboxílico (a) e com os ácidos carboxílicos: adípico (b), cítrico (c), málico(d) e tartárico(e).

Figura 50 - MEV das amostras com 2\% de diferentes ácidos e concentrações de água: TPS com ácido adípico com $20 \%$ de água (a), TPS com ácido adípico com 30\% de água (b), TPS com ácido málico com $20 \%$ de água (c), TPS com ácido málico com 30\% de água (d), TPS com ácido tartárico com $20 \%$ de água (e), TPS com ácido tartárico com 30\% de água (f),

Figura 51 - Propriedades mecânicas das amostras de TPS sem e com 2\% de ácidos

carboxílicos (adipico, cítrico, málico e tartárico) obtidas no ensaio de Tração nas direções $x$ e y de calandragem: Módulo de elasticidade (a), Resistência à tração (b) e Alongamento na ruptura (c).

Figura 52 - Origem do envelhecimento. $T_{g}$ representa a temperatura de transição vítrea, sub$T_{g}$ a temperatura de transição secundária mais baixa, e v o volume específico. 120

Figura 53 - Espectros FTIR das amostras novas e estocadas com 20\% de água: sem ácido SA2 (a) e com 2\% em massa de ácido málico - AM2 (b).

Figura 54 - Curvas DTG das amostras SA2(a), AA2(b) e AC2(c) novas e estocadas com $20 \%$ em massa de água.

Figura 55 - Curvas DTG das amostras AM2(a) e AT2(b) novas e estocadas.

Figura 56 - Curvas de raios $X$ das amostras novas e envelhecidas $7(a), 7 \bmod (b)$ e $A C 2(c) \ldots 131$ 
Figura 57 - Curvas de raios X das amostras novas e envelhecidas sem ácido(a), ácido adípico(b), ácido málico(c) e ácido tartárico(d).

Figura 58-Módulo de elasticidade, Resistência à tração e Alongamento na ruptura das amostras novas e estocadas por 12 meses: (a) amostras sem ácido, (b) amostras com 2\% de ácido adípico, (c) amostras com 4\%de ácido cítrico, (d) amostras com 2\% de ácido cítrico, (e) amostras com $2 \%$ de ácido málico, (f) amostras com 2\% de ácido tartárico. 135

Figura 59 - Fatores que contribuem para as propriedades finais de uma blenda 140

Figura 60- Princípio da mistura reativa entre dois polímeros. 145

Figura 61 - Esquema do Processamento do TPS realizado em extrusora, resfriado com ar comprimido e peletizado. 149

Figura 62 - PP doado na forma de "galhos" e após ser moído. 150

Figura 63 - Curvas de FTIR das amostras de PP reciclado e PP reciclado com anidrido maleico.

Figura 64 - Curvas de FTIR das blendas 70/30 de PP/TPS-SA e PP/TPS-AC. ......................... 153

Figura 65 - Curvas de DRX das amostras de PP. 153

Figura 66 - Curvas de DRX dos TPS puros. 154

Figura 67 - Curvas de DRX das blendas de PP/TPS sem ácido (a) e com ácido cítrico (b).....155

Figura 68-Curvas da viscosidade em função da taxa de cisalhamento à $160^{\circ} \mathrm{C}$. 156

Figura $69-M E V$ do PP reciclado (a) e do PP reciclado com anidrido maleico(b). 158

Figura 70 - MEV das blendas de PP/TPS-SA 70/30 (a), 70/30 com anidrido maleico (b), 60/40 (c), 60/40 com anidrido maleico (d), 50/50 (e) e 50/50 com anidrido maleico (f). 159

Figura 71 - MEV das blendas de PP/TPS-AC 70/30 (a), 70/30 com anidrido maleico (b), 60/40 (c), 60/40 com anidrido maleico (d), 50/50 (e) e 50/50 com anidrido maleico (f). 160

Figura 72 - MEV das blendas de PP/TPS-AM 70/30 (a), 70/30 com anidrido maleico (b), 60/40 (c), 60/40 com anidrido maleico (d), 50/50 (e) e 50/50 com anidrido maleico (f). 161

Figura 73 - MEV das blendas de PP/TPS-AT 70/30 (a), 70/30 com anidrido maleico (b), 60/40 (c), 60/40 com anidrido maleico (d), 50/50 (e) e 50/50 com anidrido maleico (f). 162 Figura 74 - MEV da blenda de PP/TPS-SA 50/50 após extração do TPS. 163

Figura 75 - MEV das blendas de PP/TPS-AC após extração do TPS 50/50 (a), 50/50 com anidrido maleico (b), 70/30 (c), 70/30 com anidrido maleico (d). 164 
Figura 76 - MEV das blendas de PP/TPS-AT após extração do TPS 50/50 (a), 50/50 com anidrido maleico (b), 70/30 (c), 70/30 com anidrido maleico (d).

Figura 77 - MEV das blendas de PP/TPS-AM após extração do TPS 50/50 com anidrido maleico (a), 70/30 com anidrido maleico (b).

Figura 78 - Propriedades Mecânicas dos TPS puros: Módulo de Elasticidade (a), Resistência a tração (b) e Alongamento na Ruptura (c). 168

Figura 79 - Propriedades Mecânicas das Blendas PP/TPS nas proporções 70/30 (a), 60/40 (b) e 50/50 (c): Resistência a tração e Módulo de Elasticidade.

Figura 80 - Propriedades Mecânicas: Módulo de Elasticidade (a), Resistência à tração (b) e Alongamento na Ruptura (c) dos TPS com e sem ácidos, novos e estocadas.

Figura 81 - Propriedades Mecânicas: Resistência à tração e Módulo de Elasticidade das Blendas PP/TPS - SA e PP/TPS - AC envelhecidas.

Figura 82 - Propriedades Mecânicas: Resistência à tração e Módulo de Elasticidade das Blendas PP/TPS - AM e PP/TPS - AT envelhecidas.

Figura 83 - Curvas de DRX da amostra PP/TPS-AC 50/50 nova e estocada 


\section{LISTA DE TABELAS}

Tabela 1 - Tabela de Planejamento $2^{2}$ com as variáveis de entrada. 67

Tabela 2-Composição e parâmetros de processamento das amostras. 69

Tabela 3 - Equações de conversão para temperatura, teor de ácido e umidade, para valores normalizados, onde $T$ é a temperatura em ${ }^{\circ} \mathrm{C}$, u é o percentual de água (umidade) e a $\mathrm{o}$ percentual de ácido.

Tabela 4 - Parâmetros normalizados para as diferentes misturas, onde T é a temperatura em

${ }^{\circ} \mathrm{C}$, u é o percentual de água (umidade) e a o percentual de ácido. 70

Tabela 5-Composição das misturas ( $m_{x}=$ massa do componente $x$ ). 72

Tabela 6 - Área relativa dos picos de éster dos espectros FTIR, para diferentes processamentos. 85

Tabela 7- Temperatura de degradação mínima e máxima para 100rpm e 8 min. 89

Tabela 8-Imagens de MEV para as amostras processadas por 8min e 100rpm. 90 Tabela 9- Tabela dos parâmetros das novas composições AC2, AC3 e 7mod e da composição 7.

Tabela 10 - Temperatura de Transição Vítrea $(\mathrm{Tg})$ e temperatura de fusão $\mathrm{Tm}$ das amostras

7, $7 \mathrm{mod}, A C 2$ e $A C 3$ 96

Tabela 11 - Propriedades mecânicas das amostras 7 e 7mod, AC2 e AC3 na direção de calandragem (y) e na direção perpendicular à de calandragem ( $x$ ). 102

Tabela 12- Resultado do Grau de substituição e do Grau de Esterificação. 103

Tabela 13 - Temperaturas de início da degradação do amido e dos TPS. 108

Tabela 14 - Análise das curvas de DSC. 109

Tabela 15 - Picos das curvas de DRX para todas as amostras. 112

Tabela 16 - Sub $T_{g}, T_{g}$ e $T_{m}$ das amostras 7, 7mod, SA2, AA2, AC2, AM2 e AT2.

Tabela 17-Micrografia com aumento de 100x das amostras novas e estocadas. 133

Tabela 22 - Picos encontrados no DRX das amostras de TPS. 154

Tabela 23 - Viscosidade dos componentes da blenda e razão de viscosidade (fase matriz: PP reciclado) para taxa de cisalhamento dos processos extrusão (1000 s-1) e injeção (10000 s-1). 
Tabela 24 - Viscosidade dos componentes da blenda e razão de viscosidade (fase matriz: PP reciclado + anidrido maleico) para taxa de cisalhamento dos processos extrusão $\left(1000 \mathrm{~s}^{-1}\right)$ e injeção $\left(10000 \mathrm{~s}^{-1}\right)$.

Tabela 25 - Comparação dos valores de módulo de elasticidade, calculados e experimentais, das blendas. 


\section{LISTA DE ABREVIATURAS E SIGLAS}

7: amostra de TPS com 4\% em massa de ácido, 30\% em massa de água, 30\% em massa de glicerol

7mod: amostra de TPS com 4\% em massa de ácido, 40\% em massa de água, 30\% em massa de glicerol processada a $100^{\circ} \mathrm{C}$

AA: ácido adípico

ABNT: Associação Brasileira de Normas Técnicas

ABRELPE: Associação Brasileira de Empresas de Limpeza Pública e Resíduos Especiais

ABS: Acrilonitrila-butadieno-estireno

AC: ácido cítrico

AC2: amostra de TPS com 2\% em massa de ácido, 20\% em massa de água, 30\% em massa de glicerol

AC3: amostra de TPS com $2 \%$ em massa de ácido, 30\% em massa de água, 30\% em massa de glicerol

AM: ácido málico

AT: ácido tartárico

ASTM: Sociedade Americana para ensaios de materiais (American Society for Testing \& Materials)

CNUDS: Conferência das Nações Unidas sobre Desenvolvimento Sustentável

DMTA: análise termodinâmico-mecânica

DRX: difração de raios-X

DSC: calorimetria exploratória diferencial

DTG: derivada da curva de termogravimetria

EAA: poli(etileno-co-ácido acrílico)

EVOH: poli(etileno-co-vinil álcool)

EPUSP: Escola Politécnica da Universidade de São Paulo 
FTIR: Espectroscopia Vibracional de Absorção no infravermelho com transformada de Fourier

GE: Grau de Esterificação

GMS: monoestearato de glicerol

GS: Grau de Substituição

ISO: International Organization for Standardization

MET: microscopia eletrônica de transmissão

MEV: microscopia eletrônica de varredura

MO: microscopia óptica

PA: poliamida

PBAT: poli (butilenoadipato-co-tereftalato)

PBSA: poli (butileno succinato - co - adipato)

PCL: poli(e-caprolactona)

PE: polietileno

PEAD: Polietileno de alta densidade

PEGMA: poli(etileno-co-metacrilato de glicidila)

PHB: poli- $\beta$-(hidroxibutirato)

PLA: poli (ácido lático)

PMMA: poli(metacrilato de metila)

PP: polipropileno

PP-g-MA: polipropileno grafitizado com anidrido maleico

PP-g-PE: polipropileno grafitizado com polietileno

PS: poliestireno

PVP: polivinilpirrolidona

SA2: amostra de TPS com $20 \%$ de água

SA3: amostra de TPS com $30 \%$ de água

TG: análise termogravimétrica

TPS: amido termoplástico 


\section{LISTA DE SÍMBOLOS}

a - percentual de ácido

$d_{n}$ - diâmetro numérico médio,

$\mathrm{d}_{\mathrm{v}}$ - diâmetro volumétrico médio

$E_{n}$ - energia de ativação

$\mathrm{K}$ - consistência

k - velocidade da reação

$\mathrm{N}$ - concentração molar

n - índice da lei de potência.

$\eta$ - viscosidade,

$\eta_{d}$ - viscosidade da fase dispersa

$\eta_{m}$ - viscosidade da matriz

$R$ - constante dos gases $(8,31 \mathrm{~J} / \mathrm{mol} . \mathrm{K})$

$\mathrm{T}$ - temperatura

$T_{c}$ - temperatura de cristalização

Tdegrad - temperatura de degradação

$\mathrm{T}_{\mathrm{g}}$ - temperatura de transição vítrea

$T_{\text {gel }}$ - temperatura de gelatinização

$T_{m}$-- temperatura de fusão

u - percentual de água

$\mathrm{V}$ - volume $(\mathrm{L})$

$\mathrm{Y}$ - tensão interfacial

$\lambda_{v}$ - razão de viscosidade

Ysup - tensão superficial

$\gamma$ - taxa de deformação

$W_{a}$ - trabalho de adesão entre as duas fases 


\section{SUMÁRIO}

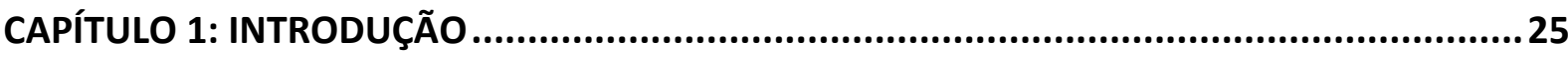

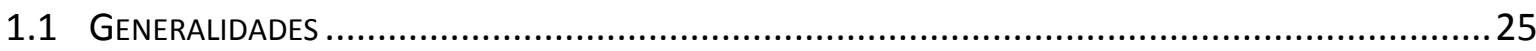

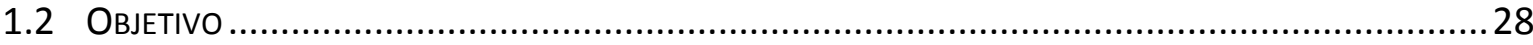

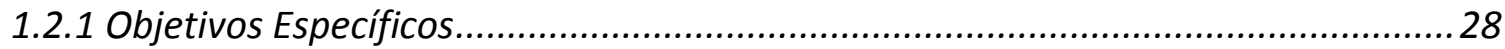

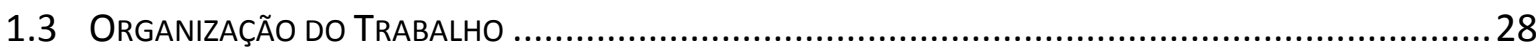

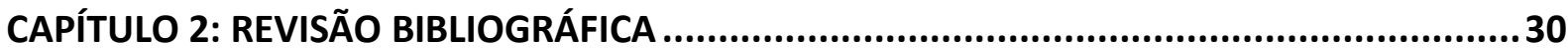

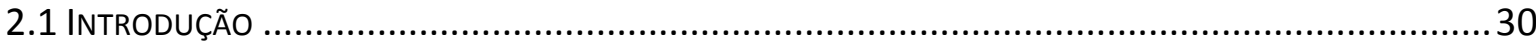

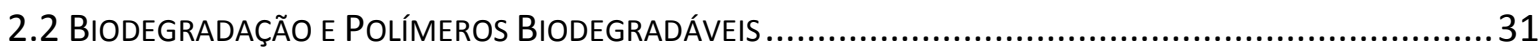

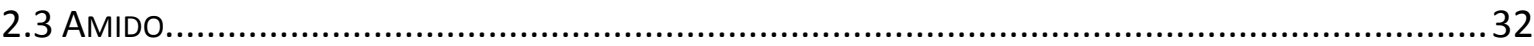

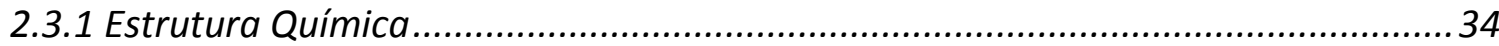

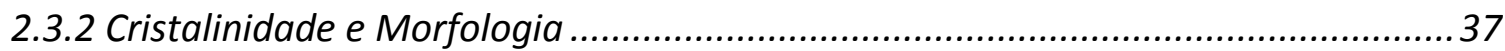

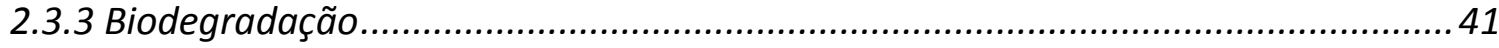

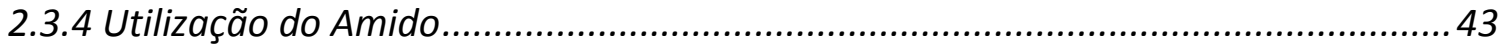

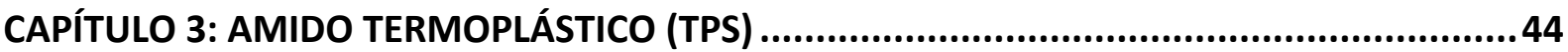

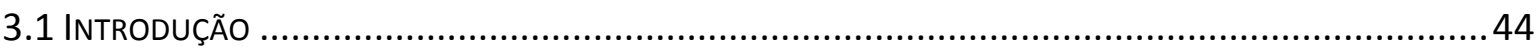

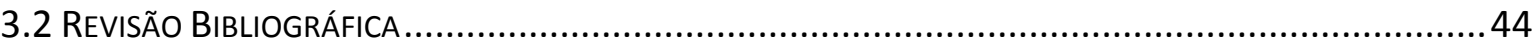

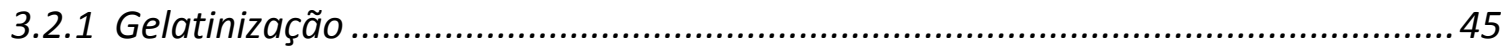

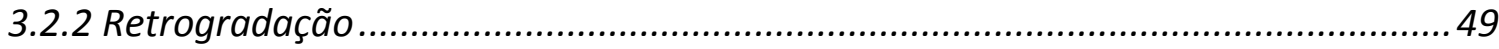

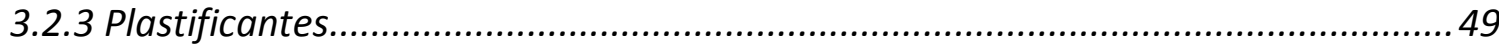

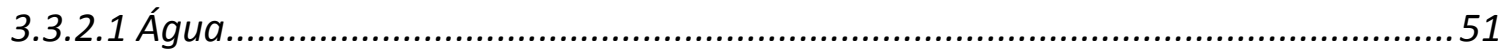

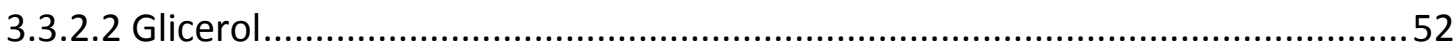

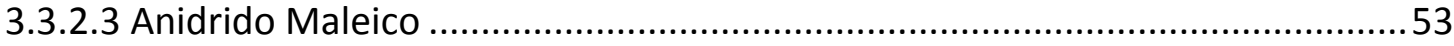

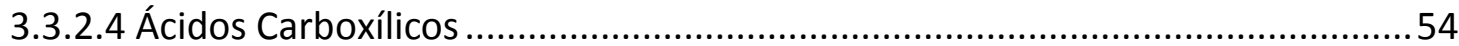

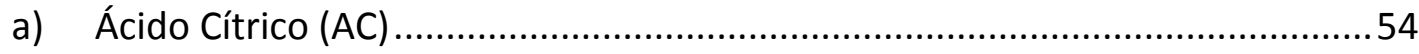

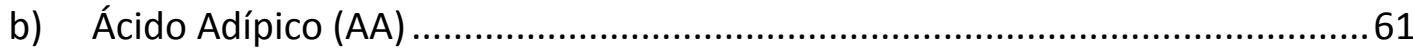

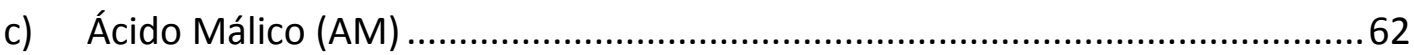

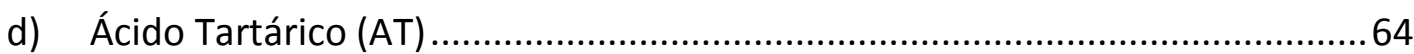

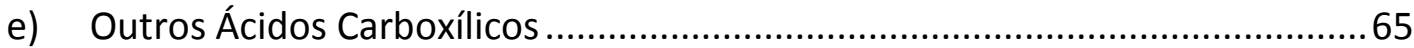




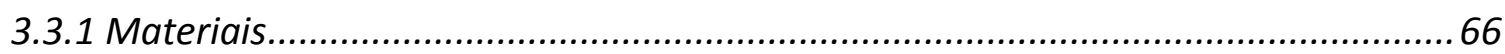

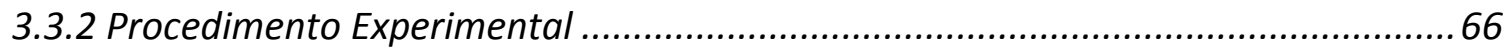

3.3.2.1 Etapa I: Otimizando a composição e a condição de processamento do TPS com ácido cítrico

3.3.2.1.1 Preparação do TPS 70

3.3.2.2 Etapa II: Otimizando a composição e a condição de processamento do TPS com ácido cítrico

3.3.2.3 Etapa III: Otimizando a composição e a condição de processamento do TPS com ácido cítrico

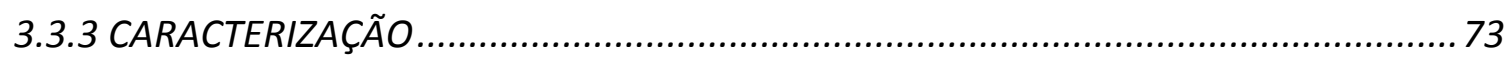

3.3.3.1 Curvas de Torque 73

3.3.3.2 Espectroscopia Vibracional de Absorção no infravermelho com transformada de Fourier (FTIR) 73

3.3.3.3 Análise Termogravimétrica 74

3.3.3.4 Calorimetria Exploratória Diferencial (DSC) …............................................. 74

3.3.3.5 Difração de Raios X (DRX) .......................................................................... 74

3.3.3.6 Microscopia Eletrônica de Varredura (MEV) ................................................... 75

3.3.3.7 Propriedades Mecânicas: Ensaio de Tração ....................................................75

3.3.3.8 Grau de Substituição (GS) e Grau de Esterificação (GE) .................................76

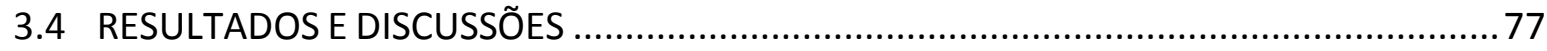

3.4.1 Etapa I: Escolha da composição do TPS, utilizando ácido cítrico ......................... 77

3.4.1.1 Análise das curvas de torque geradas durante o Processamento ....................78

3.4.1.2 Espectroscopia Vibracional de Absorção no infravermelho com transformada

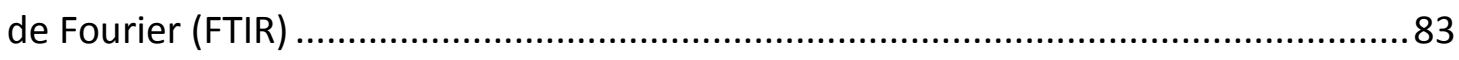

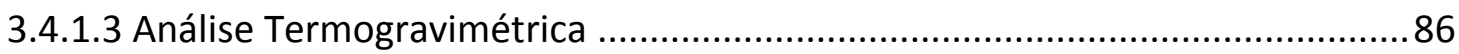

3.4.1.4 Microscopia Eletrônica de Varredura (MEV) ................................................89

3.4.2 Etapa II: Novas composições de TPS com ácido cítrico ........................................ 91

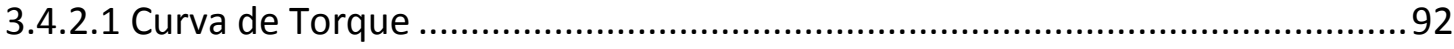


3.4.2.2 Espectroscopia Vibracional de Absorção no infravermelho com transformada

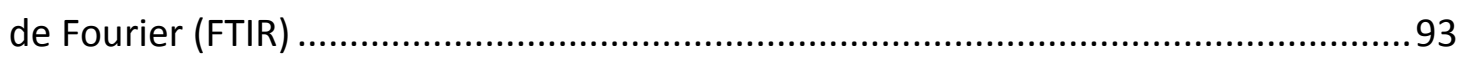

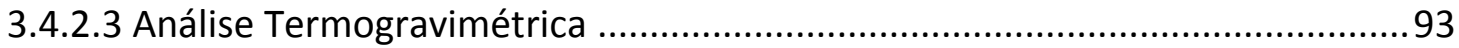

3.4.2.4 Calorimetria Exploratória Diferencial (DSC) …............................................95

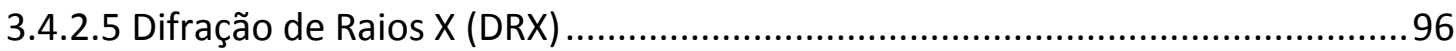

3.4.2.6 Microscopia Eletrônica de Varredura (MEV)...............................................100

3.4.2.7 Propriedades Mecânicas: Ensaio de Tração ....................................................101

3.4.2.8 Grau de Substituição (GS) e Grau de Esterificação (GE) ...............................102

3.4.3 Etapa III: Analisando o TPS utilizando outros Ácidos Carboxílicos ....................... 103

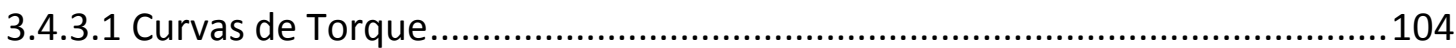

3.4.3.2 Espectroscopia Vibracional de Absorção no infravermelho com transformada

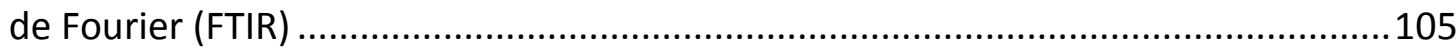

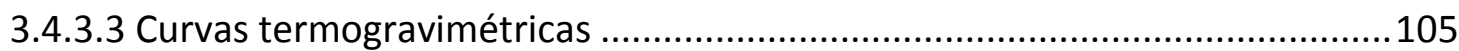

3.4.3.4 Calorimetria Exploratória Diferencial (DSC) …............................................ 109

3.4.3.5 Difração de Raios X (DRX) .........................................................................110

3.4.3.6 Microscopia Eletrônica de Varredura (MEV) ..................................................112

3.4.3.7 Propriedades Mecânicas: Ensaio de Tração .................................................114

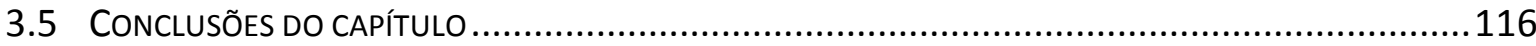

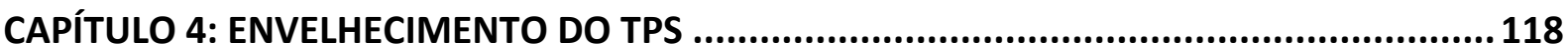

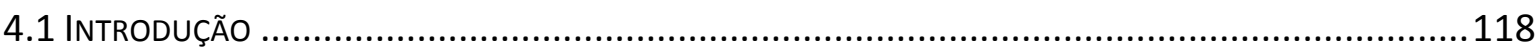

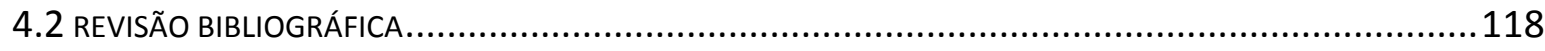

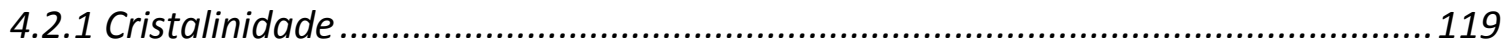

4.2.2 Temperatura de transição vítrea ......................................................................... 120

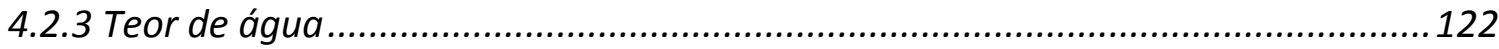

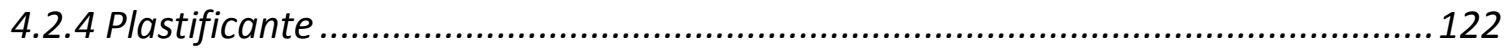

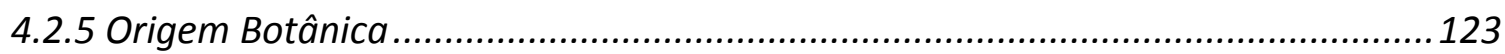

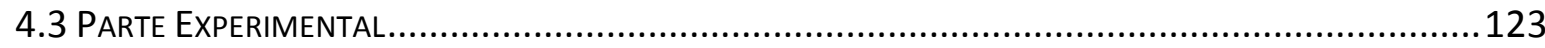

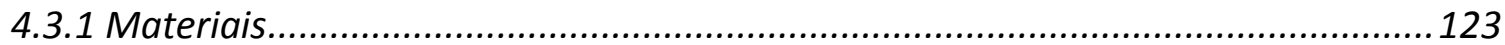

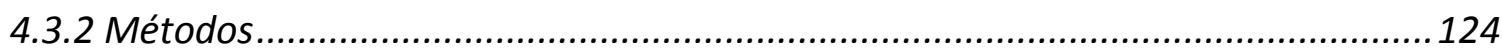


4.3.2.1 Espectroscopia Vibracional de Absorção no infravermelho com transformada

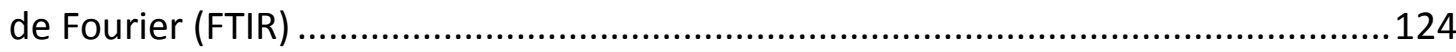

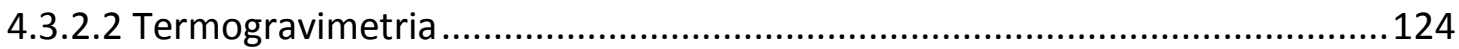

4.3.2.3 Calorimetria Exploratória Diferencial (DSC) ............................................... 124

4.3.2.4 Difração de Raios X (DRX) ...........................................................................124

4.3.2.5 Microscopia Eletrônica de Varredura (MEV) .................................................124

4.3.2.6 Propriedades Mecânicas: Ensaio de Tração ..................................................125

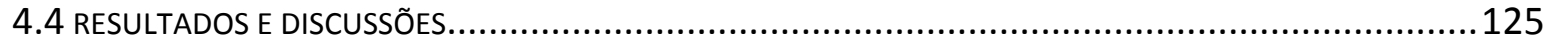

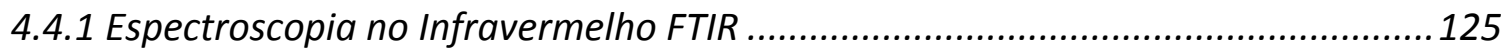

4.4.3 Calorimetria Exploratória Diferencial (DSC) ................................................... 128

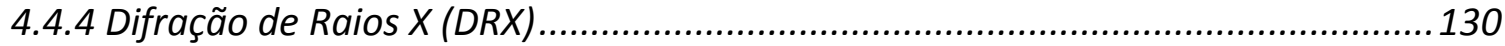

4.4.5 Propriedades Mecânicas: Ensaio de Tração .......................................................... 134

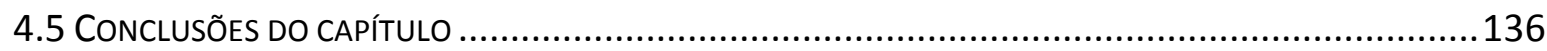

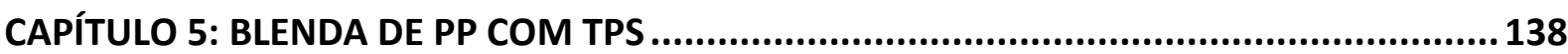

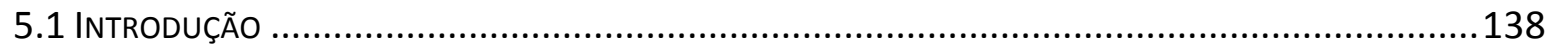

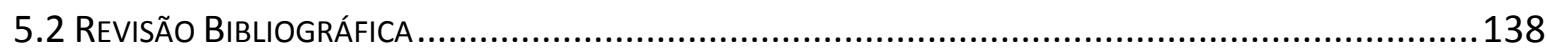

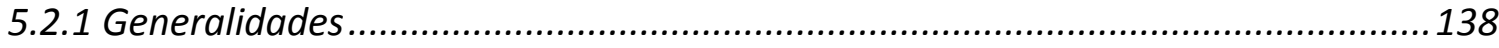

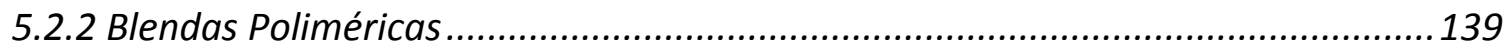

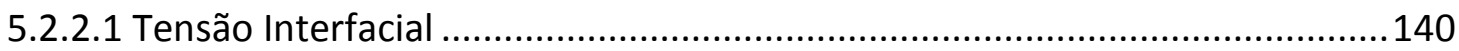

5.2.2.2 Propriedades reológicas dos polímeros formadores da blenda .................... 141

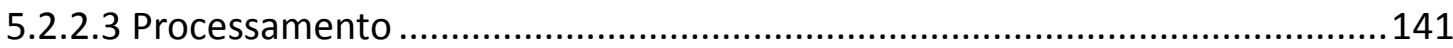

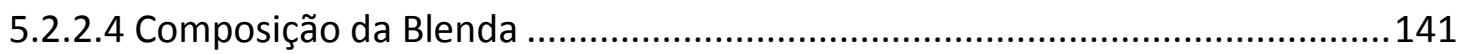

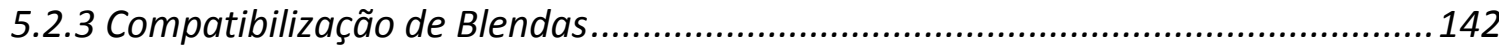

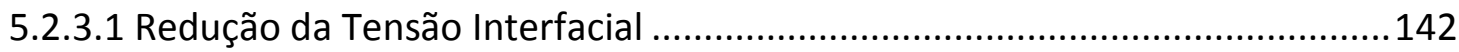

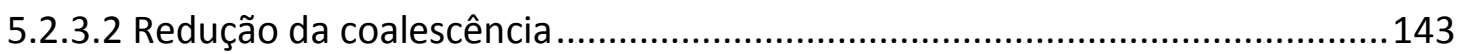

5.2.3.3 Aumento de adesão entre as fases ...........................................................143

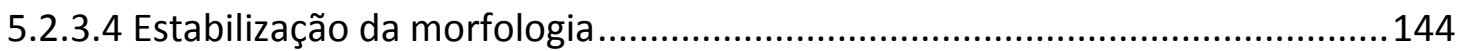

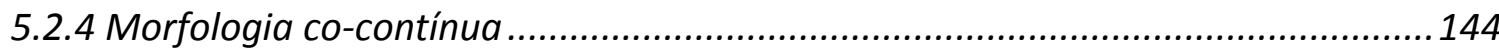




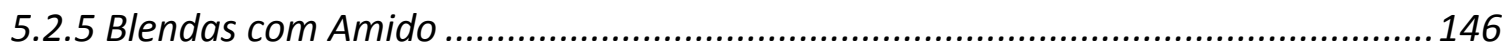

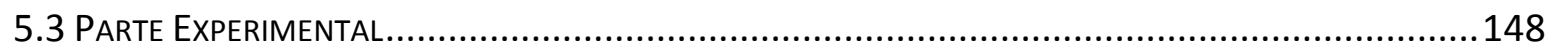

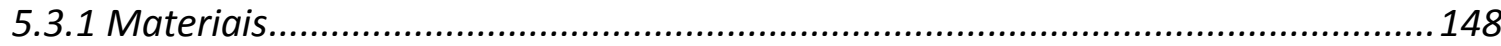

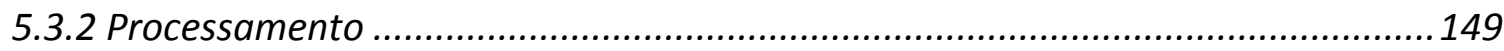

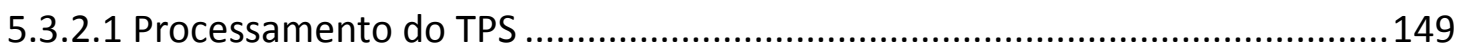

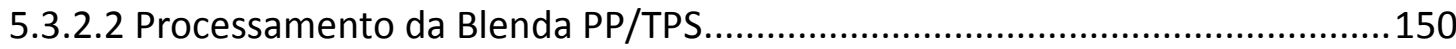

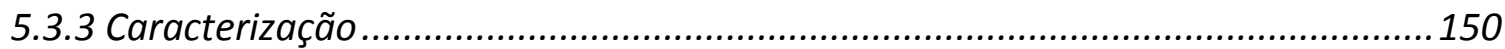

5.3.3.1 Vibracional de Absorção no infravermelho com transformada de Fourier ...150

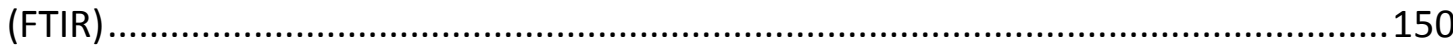

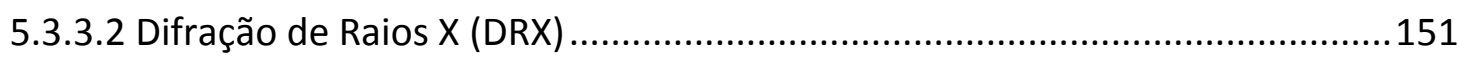

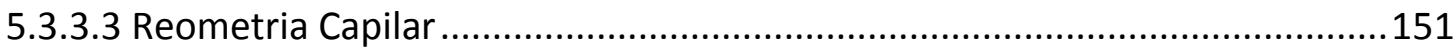

5.3.3.4 Microscopia Eletrônica de Varredura (MEV).............................................151

5.3.3.5 Propriedades Mecânicas: Ensaio de Tração .....................................................151

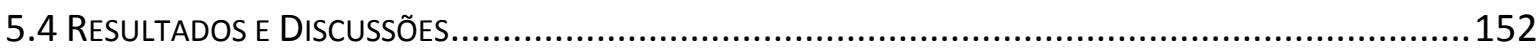

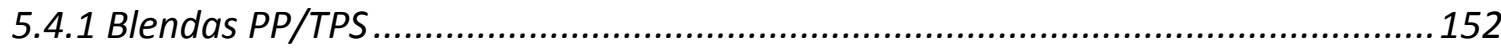

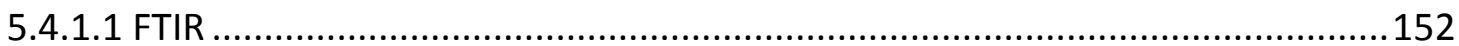

5.4.1.2 Difração de Raios X (DRX) ......................................................................... 153

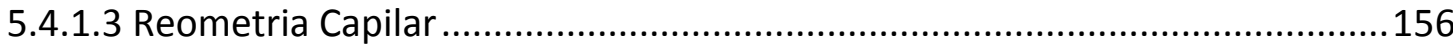

5.4.1.4 Microscopia Eletrônica de Varredura (MEV)..............................................157

5.4.1.5 Propriedades Mecânicas: Ensaio de Tração .....................................................166

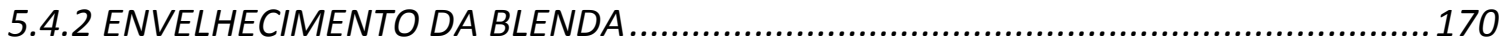

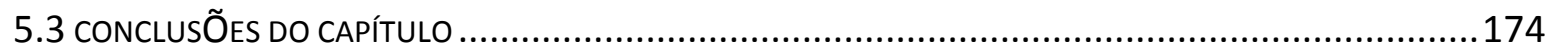

CAPÍTULO 6 - CONCLUSÕES, CONSIDERAÇÕES FINAIS E SUGESTÕES PARA TRABALHOS

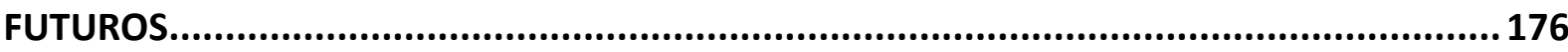

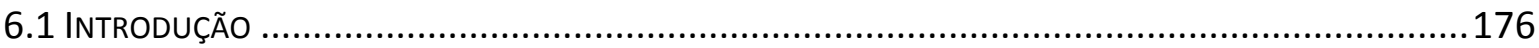

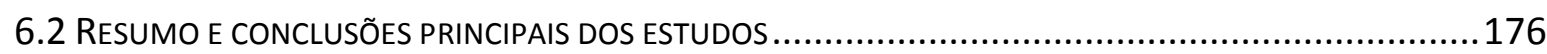

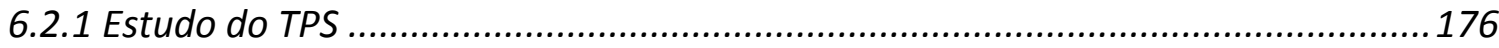

6.2.2 Estudo sobre o Envelhecimento do TPS ........................................................177

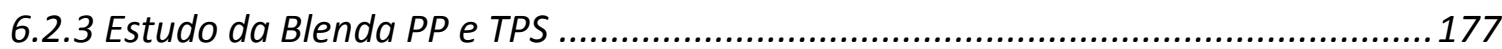




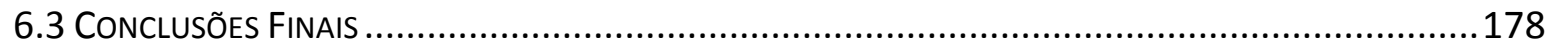

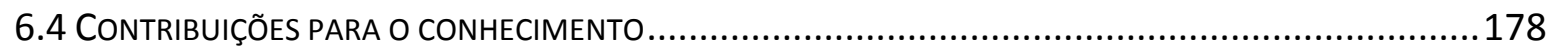

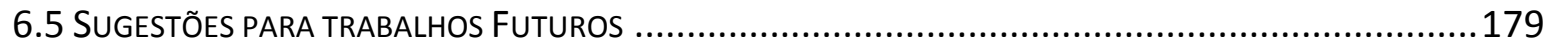

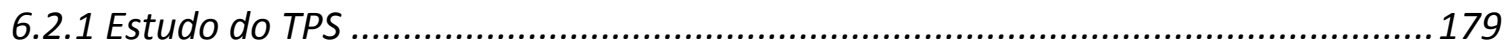

6.2.2 Estudo sobre o Envelhecimento do TPS .......................................................179

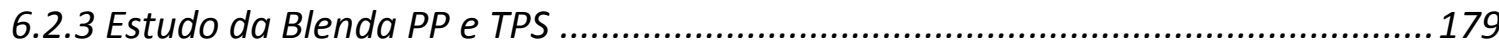

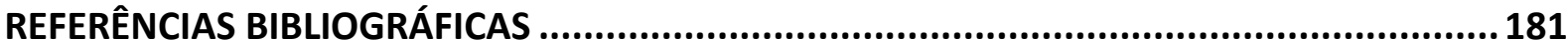




\section{CAPÍTULO 1: INTRODUÇÃO}

\subsection{GENERALIDADES}

Nas últimas décadas, os materiais poliméricos sintéticos tornaram-se um dos principais produtos utilizados pelo homem moderno, substituindo produtos metálicos e cerâmicos, em diversas aplicações [1]. Como exemplo das diversas formas de utilização temos [1]:

- As fibras de poliamidas que competem com o algodão, a seda, a lã e o couro;

- O poliestireno, o polipropileno e outros tantos que substituem a madeira e o ferro;

- O PVC, o poliéster e o policarbonato que substituem o vidro.

O setor de polímeros no Brasil tem se desenvolvido de forma acelerada. No ano de 2000 , a produção de resinas termoplásticas foi de 3,9 milhões toneladas, já no ano de 2009, a produção saltou para 5,5 milhões de toneladas [2]. Isso ocorreu devido a constante melhoria de diversas propriedades dos polímeros sintéticos (processabilidade, propriedades mecânicas, degradação, resistências), logo, conseguiu atingir um maior mercado de aplicações destes materiais. Em 2013, o consumo aparente (total produzido, acrescido do importado, menos o exportado) de plásticos no Brasil atingiu a marca de 8 milhões de toneladas [3].

No entanto, esse aumento da produção e consumo de plásticos ocasionou maiores problemas ambientais, pois esse material leva centenas de anos para se decompor. Dessa forma, precisa-se encontrar soluções para diminuir e/ou restringir seus impactos ambientais.

O governo brasileiro demonstra preocupação com o impacto ambiental. No ano de 2010 foi aprovada a Política Nacional de Resíduos Sólidos, que incentiva o retorno de produtos pós-consumo para os fabricantes e distribuidores, os quais deverão encontrar meios de reutilizar, reciclar e dispor esses produtos de uma maneira menos impactante para o meio ambiente [4]. 
Segundo a ABRELPE (Associação Brasileira de Empresas de Limpeza Pública e Resíduos Especiais), o volume de plásticos pós-consumo gerado em 2013 foi de 3.262 toneladas, sendo que apenas $21 \%$ desse resíduo foi destinado à reciclagem mecânica. Estes dados apontam que, aproximadamente $80 \%$ de todo material plástico produzido e/ou consumido, é utilizado apenas uma vez e depois descartado em aterros sanitários ou indevidamente em: lixões, ruas e cursos d'água [5] [6].

Dentre as soluções propostas para o gerenciamento dos problemas causados pelos materiais poliméricos, encontra-se o desenvolvimento sustentável. Este visa, entre outras coisas, aliar desenvolvimento econômico e tecnológico com políticas ambientais e sociais. As formas encontradas para utilizar de forma sustentável os polímeros são: a reciclagem, a incineração e o uso de polímeros biodegradáveis [7].

Atualmente, o uso de polímeros biodegradáveis vem se tornando uma alternativa muito interessante para a sociedade, uma vez que viabiliza o desenvolvimento sustentável. O tema, polímeros biodegradáveis, atrai tanto o interesse da comunidade científica, o que pode ser verificado pelos inúmeros artigos publicados sobre o tema, quanto da indústria, demonstrado pelo crescimento do mercado, que é de aproximadamente 20 a $30 \%$ por ano [8].

Polímeros biodegradáveis podem ser definidos como materiais que podem se decompor rapidamente pela ação de micro-organismos, tais como bactérias e fungos. Ao passo que os polímeros ditos não biodegradáveis, levem centenas de anos para serem bioassimilados.

É notável a melhora já obtida em propriedades mecânicas e físico-químicas dos plásticos biodegradáveis. Sua oferta vem aumentando expressivamente. Estima-se que em 2016, a produção mundial atingirá a marca de 6 milhões de toneladas. Porém este número não é expressivo se comparado à produção anual de plásticos convencionais, a qual é de 280 milhões de toneladas [6] [9].

Pode-se notar, que ainda será necessário percorrer um longo caminho para que os polímeros biodegradáveis possam apresentar competitividade direta com a maioria dos polímeros sintéticos de larga utilização. Para se tornarem competitivos, as propriedades térmicas e mecânicas ainda devem ser melhoradas. Outro ponto 
importante é a questão custo, polímeros biodegradáveis não possuem preço competitivo, principalmente quando se analisa o mercado de commoditties [6] [9].

Dentre os polímeros biodegradáveis pode-se destacar o amido termoplástico (TPS) [10]. O amido pode se tornar um material termoplástico pela adição de um plastificante, como água ou álcool, e o produto resultante é um polímero biodegradável, o amido termoplástico. Suas propriedades mecânicas dependem da concentração e do tipo de plastificante, sendo que estes podem sofrer exsudação $[4,5]$.

Neste trabalho foi estudada a obtenção e caracterização do TPS utilizando amido de milho, $30 \%$ de glicerol, água e os ácidos carboxílicos: adípico, cítrico, málico e tartárico, para analisar como estes materiais influenciam na plastificação e no envelhecimento do material. Como não existe um consenso da composição ideal de água no material, nem do processamento, foi realizado um planejamento estatístico para se obter um material com propriedades mecânicas, térmicas e de processamento superiores. Após isso, os ácidos carboxílicos foram misturados para serem utilizados como plastificantes no intuito de melhorar essas propriedades. Existem estudos avaliando apenas o ácido cítrico como um segundo plastificante, logo, torna-se interessante avaliar outros ácidos carboxílicos e seus protocolos de mistura.

Sabe-se que um dos maiores problemas do TPS, apenas com água e glicerol como plastificantes, é a perda de propriedades durante o envelhecimento, então, a adição destes ácidos também visa melhorar ou diminuir a exsudação do plastificante, mantendo a cristalinidade do material, bem como de suas propriedades mecânicas e térmicas.

Pode-se ainda melhorar as propriedades mecânicas do TPS misturando-o com outros polímeros, obtendo uma blenda polimérica. Dessa forma, tornou-se interessante estudar o TPS, que é biodegradável, com um PP reciclado. O TPS e o PP são polímeros imiscíveis devido as suas diferentes estruturas químicas. Por este motivo, a compatibilização da blenda foi estudada com o intuito de obter melhores propriedades mecânicas. No estudo da compatibilização foram utilizados os ácidos carboxílicos: cítrico, málico e tartárico. Também foi analisado o envelhecimento da 
blenda. Poucos foram os estudos até o momento sobre esta blenda, com isso, tratase de uma mistura com amplo campo de investigação.

\subsection{OBJETIVO}

Este trabalho tem como objetivo preparar e caracterizar o amido termoplástico (TPS), avaliar seu envelhecimento em condições de estocagem e estudar misturas de TPS com polipropileno (blenda).

\subsubsection{Objetivos Específicos}

- Avaliação da modificação do TPS com adição de ácido cítrico, visando obter melhores propriedades mecânicas e processabilidade, em relação ao TPS sem adição de ácido;

- Avaliar a possibilidade de utilização de ácidos carboxílicos para plastificar o TPS;

- Analisar o envelhecimento do TPS;

- Obter e caracterizar blendas de PP reciclado e TPS, com e sem adição de ácidos carboxílicos e anidrido maleico como compatibilizantes.

\subsection{ORGANIZAÇÃO DO TRABALHO}

O capítulo 2 apresenta uma breve revisão bibliográfica sobre biodegradação, polímeros biodegradáveis e sobre o amido e suas propriedades.

O capítulo 3 inicia-se com uma revisão bibliográfica sobre amido termoplástico. Posteriormente descreve-se o procedimento experimental, o qual foi dividido em três partes:

- Primeiramente foi realizado um planejamento estatístico para verificar qual a composição ótima para o amido termoplástico (TPS), preparado a partir de amido de milho, água, glicerol e ácido cítrico;

- Para complementar a etapa de otimização da composição e das condições de processamento do TPS, foram preparadas mais 4 
amostras de TPS, variando-se os teores de água e de ácido cítrico e a temperatura de processamento;

- E por fim, utilizando o que foi considerada a composição ótima para o TPS, estudou-se a substituição do ácido cítrico por outros três ácidos carboxílicos: adípico, málico e tartárico, para verificar a influência dos mesmos nas propriedades do TPS.

O capítulo 4 apresenta a análise de envelhecimento do TPS em condições de estocagem, sem e com os ácidos carboxílicos.

O capítulo 5 apresenta o estudo da blenda formada pelo copolímero PP-g-PE reciclado (resíduo industrial) com o TPS, sem e com adição dos ácidos cítrico, málico e tartárico, e com e sem a adição de anidrido maleico.

Por fim, o capítulo 6 traz as principais conclusões do presente estudo, bem como sugestões para trabalhos futuros. 


\section{CAPÍTULO 2: REVISÃO BIBLIOGRÁFICA}

\subsection{INTRODUÇÃO}

O avanço tecnológico e industrial favorece o descarte e o acúmulo de grande quantidade de resíduos sólidos e dejetos, e estes resíduos podem ter como destino: aterramento, compostagem, reciclagem ou incineração. A maioria dos resíduos tem como destino os aterros sanitários ou os chamados lixões, gerando impactos ambientais.

O agravamento do impacto ambiental faz com que cada vez mais governantes comecem a se preocupar e incentivar atividades, visando o desenvolvimento sustentável.

O conceito de desenvolvimento sustentável foi consagrado no Relatório Brundtland, publicado em 1987 pela World Commission on Environment and Development, uma comissão das Nações Unidas, e foi definido como: "desenvolvimento capaz de atender às necessidades da geração atual, sem comprometer as necessidades da geração futura" [10]. Em 2012, a Conferência das Nações Unidas sobre Desenvolvimento Sustentável (CNUDS), também conhecida como Rio+20, estabeleceu que: "Desenvolvimento sustentável é o modelo que prevê a integração entre economia, sociedade e meio ambiente. Em outras palavras, é a noção de que o crescimento econômico deve levar em consideração a inclusão social e a proteção ambiental" [12].

Este conceito vem ao encontro ao estímulo para o desenvolvimento de polímeros de fonte renovável, os quais diferem dos polímeros sintéticos, que advém do petróleo, que é uma fonte esgotável. E também estimula o desenvolvimento de polímeros biodegradáveis, pois estes, em condições ideais, irão se decompor, e assim, não afetará de maneira drástica o ambiente. Bem como a reciclagem dos materiais. 


\subsection{BIODEGRADAÇÃO E POLÍMEROS BIODEGRADÁVEIS}

De acordo com a norma ABNT NBR 15448-1 [7], a biodegradação é a degradação causada por atividade biológica de ocorrência natural, por ação enzimática. Neste processo, os micro-organismos (bactérias, fungos e suas enzimas) utilizam os compostos orgânicos como fonte de alimento, convertendo-os em compostos mais simples, e são redistribuídos através de ciclos elementares como o do carbono, do nitrogênio e do enxofre.

Os micro-organismos, quando entram em contato com os polímeros biodegradáveis, secretam enzimas que os quebram em segmentos menores, permitindo o seu consumo [8].

Há dois mecanismos de biodegradação:

- Biótico: ocorre por ação enzimática, onde as reações de biodegradação são catalisadas por enzimas produzidas pelos micro-organismos ou;

- Abiótico: ocorre por ataques físico-químicos, que ocorrem no processo de digestão, no qual normalmente são produzidos ácidos.

Os polímeros biodegradáveis são uma classe de polímeros que possuem seu processo degradativo ativado por meio de síntese bioquímica enzimática, a qual é ocasionada por micro-organismos como bactérias, fungos e algas. Estes consomem o material polimérico como alimento, transformando-o em água $\left(\mathrm{H}_{2} \mathrm{O}\right)$, dióxido de carbono $\left(\mathrm{CO}_{2}\right)$, energia e biomassa (húmus). Os polímeros biodegradáveis também são susceptíveis às degradações não enzimáticas como a hidrólise e a fotólise [9].

Nos materiais poliméricos, o termo degradação, refere-se a qualquer mecanismo que leve a danos irreversíveis em algum tipo de propriedade do material. Os polímeros podem ser degradados por diversos mecanismos como fotodegradação, termodegradação, degradação mecânica, hidrólise, biodegradação, foto-oxidação e oxidação térmica [13].

Os polímeros considerados biodegradáveis são aqueles que conseguem se decompor rapidamente (em média de poucos meses a até dois anos), enquanto a grande maioria dos polímeros (não biodegradáveis) leva centenas de anos para ser bioassimilado. 
Os polímeros naturais ou biopolímeros são aqueles que ocorrem na natureza, produzidos por plantas, animais e micro-organismos (fontes renováveis). Estes vêm despertando grande interesse acadêmico e industrial, com destaque para os polissacarídeos (amido, colóides, poliosideos, entre outros) e as proteínas (colágeno, glúten, miofibrilares de peixe, de soja, de milho, entre outros). Os biopolímeros são materiais considerados naturalmente biodegradáveis, pois, em sua maioria, apresentam uma estrutura química formada por átomos de oxigênio e nitrogênio.

Mesmo que um material seja considerado biodegradável, sua decomposição efetiva na natureza depende de uma série de fatores, por exemplo [14]:

- Forma de descarte (aterros);

- Presença de micro-organismos específicos;

- Geração de enzimas apropriadas para a decomposição de polímeros específicos;

- Temperatura e pH;

- Quantidade de oxigênio no meio;

- Nutrientes presentes, entre outros.

Sendo assim, para um polímero ser classificado como biodegradável, não significa que ele será degradado em qualquer meio.

A formação do termoplástico biodegradável de amido envolve ligações cruzadas inter e intramoleculares. O grau de coesão depende: da estrutura das moléculas, do processo de fabricação, dos parâmetros físicos (temperatura, pressão, tipo de solvente, entre outros) e da presença de plastificante.

A seguir, serão apresentadas as principais características e propriedades do polímero estudado nesse trabalho, o amido, que além de ser biodegradável é um biopolímeros.

\subsection{AMIDO}

O amido é um polissacarídeo produzido por algumas plantas para armazenar energia, ou seja, é um carboidrato. Ele é armazenado intracelularmente na forma de grânulos esféricos que medem de 2-100 $\mu \mathrm{m}$ de diâmetro. Para comercialização, os 
amidos são isolados dos grãos (arroz, batata, milho, trigo,) ou dos tubérculos (batata, mandioca, tapioca).

Devido ao cultivo intensivo de grãos e tubérculos, o amido é encontrado abundantemente na natureza, possuindo baixo custo e sendo renovável. O amido é uma fonte de carboidrato, mas também pode ser convertido quimicamente, fisicamente e biologicamente em compostos úteis para a indústria. As variações de tamanho, forma, associações e composição (glicosídeos, umidade, proteínas, lipídeos, proteínas e minerais) são dependentes de sua origem botânica [15], como mostra a Figura 1. Na Figura 1 são dados os percentuais das duas principais estruturas do amido de acordo com a origem botânica: a amilose e a amilopectina, que serão explicadas no item 2.3.1.

Figura 1 - Características de alguns amidos comerciais.

\begin{tabular}{|c|c|c|c|c|}
\hline Fonte & Forma do granulo & $\begin{array}{c}\text { Diametro } \\
(\mu \mathrm{m})\end{array}$ & $\begin{array}{c}\text { Amilose } \\
(\%)\end{array}$ & $\begin{array}{c}\text { Amilopectina } \\
(\%)\end{array}$ \\
\hline Milho & & $5-26$ & 28 & 72 \\
\hline Arroz & & $3-8$ & 30 & 70 \\
\hline Mandioca & & 5-30 & $14-18$ & $86-82$ \\
\hline Batata & & $15-100$ & $18-20$ & $82-80$ \\
\hline
\end{tabular}

Fonte: [16] 


\subsubsection{Estrutura Química}

Os grânulos dos amidos são compostos principalmente (98 a 99\%, base seca) por dois tipos de polissacarídeos, que são homopolímeros de D-glicose: a amilose e a amilopectina.

A amilose consiste em unidades de anidroglicose ligadas primariamente através de ligações glicosídicas $\alpha-D-(1 \rightarrow 4)$. É um material heterogêneo e possui uma estrutura linear de a-1,4 ligando as unidades de glicose, como mostra a Figura 2a. Dependendo da sua origem e das condições de processamento durante sua extração, a massa molar da amilose pode variar na ordem de $10^{5}$ a $10^{6} \mathrm{~g} / \mathrm{mol}$, sendo assim, cerca de 10 vezes maior que os polímeros convencionais, e, o seu grau de polimerização médio é de 320 a 4920.

A amilopectina é uma estrutura altamente ramificada de cadeias curtas de $\alpha$ 1,4 ligadas por $\alpha-1,6$, formando assim ligações cruzadas entre um grupo hidroxila de uma cadeia de glicose e o carbono 6 da glicose de outra cadeia [17], como mostra a Figura $2 \mathrm{~b}$. A amilopectina possui massa molar da ordem de $10^{6}$ a $10^{9} \mathrm{~g} / \mathrm{mol}$ e grau de polimerização em torno de $8 \times 10^{3}$ a $13 \times 10^{3}$. A amilopectina possui massa molar maior que a da amilose, essa elevada massa molar faz com que a amilopectina reduza a mobilidade das cadeias poliméricas.

As cadeias de amilopectina podem se organizar de maneiras distintas, surgindo uma classificação de cadeias do tipo A, B ou C (Figura 3). O tipo A é composto por uma cadeia não-redutora de glicoses unidas por ligações $\alpha-(1-4)$ sem ramificações, sendo unida a uma cadeia tipo $B$ através de ligações $\alpha-(1-6)$. As cadeias do tipo $B$ são compostas por glicoses ligadas em $\alpha-(1-4)$ e $\alpha-(1-6)$, contendo uma ou várias cadeias tipo $A$ e podem conter cadeias tipo $B$ unidas através de um grupo hidroxila primário. Já a cadeia $C$ é única em uma molécula de amilopectina, sendo composta por ligações $\alpha-(1-4)$ e $\alpha-(1-6)$, com grupamento terminal redutor. 
Figura 2 - Representação da Estrutura Química (a) da Amilose e (b) da Amilopectina.

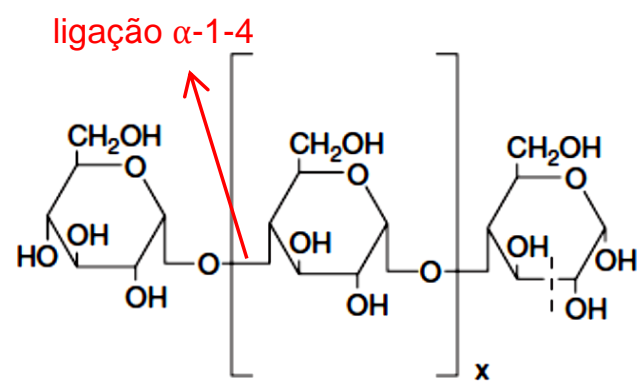

(a)

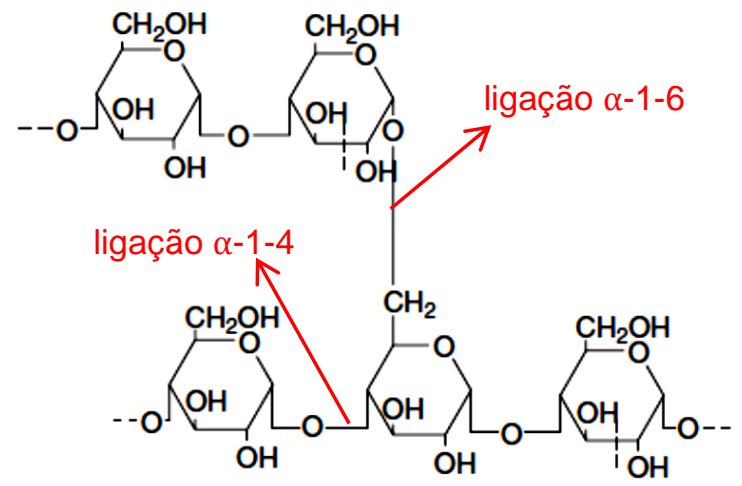

(b)

Fonte: Adaptado [15]

Figura 3 - Classificação das cadeias de amilopectina em tipo A, B e C.

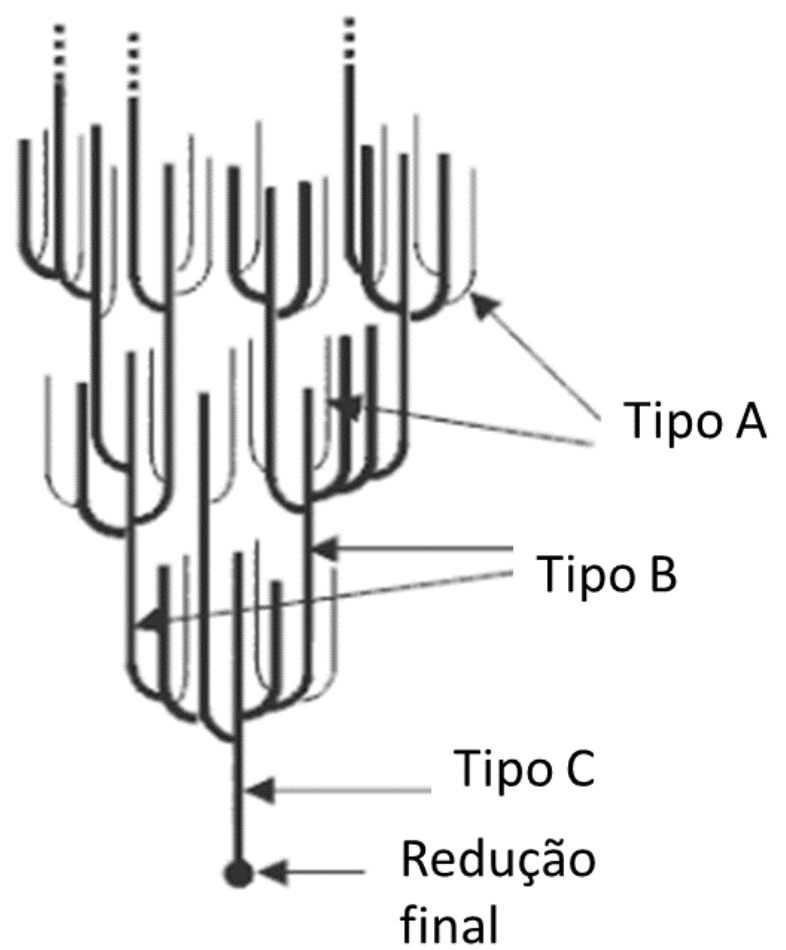

Fonte: Adaptado de [18] 
Devido às ligações do tipo $\alpha$, presentes entre as unidades de glicose, e por causa das ligações intermoleculares (principalmente ligações de hidrogênio devido às hidroxilas), pode-se observar uma estrutura em dupla hélice nas seções lineares de amilopectina, como mostra a Figura 4. Esta configuração de ligação torna o amido bem mais susceptível a ataques químicos do que, por exemplo, a celulose (polissacarídeo de glicose, como o amido, porém com ligações do tipo $\beta$ ).

As moléculas de D-glicose possuem dois importantes grupos funcionais: o grupo hidroxila $-\mathrm{OH}$, suscetível às reações de substituições e de caráter nuclefílico, e as ligações C-O-C, suscetíveis à ruptura de cadeias [19].

Podem ser obtidas modificações de várias propriedades devido as diversas reações com o grupo hidroxila. Como exemplo, a ligação cruzada e de $-\mathrm{OH}$ alteram a estrutura da cadeia, aumentam a viscosidade, reduzem a retenção de água e aumentam a resistência ao cisalhamento.

Figura 4 - Figuras esquemáticas da (a) estrutura tridimensional em dupla hélice dos segmentos lineares da amilopectina e da (b) estrutura em cachos da amilopectina.

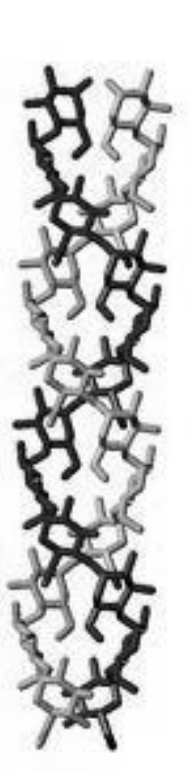

(a)

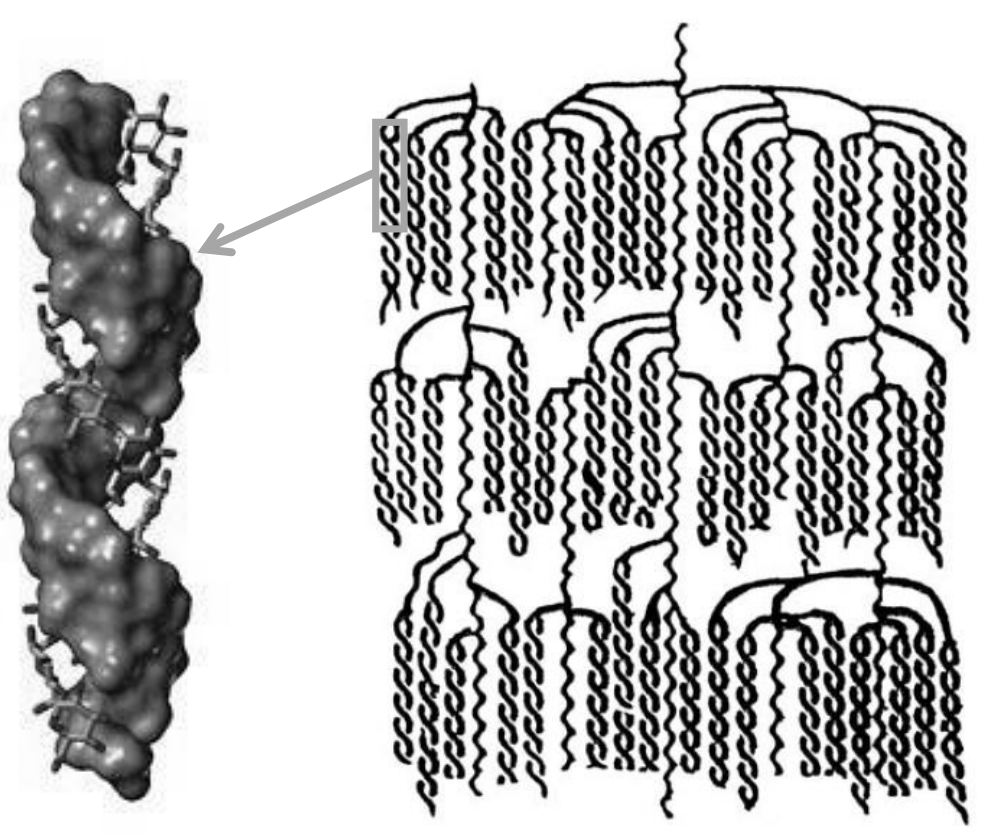

(b)

Fonte: Adaptado de [15]. 
A maioria dos amidos nativos, tais como o de milho, de trigo e de batata, contém $20-30 \%$ de amilose. Também podem ser encontradas na superfície grânulos de proteínas e lipídeos $(<0,6 \%)$. Ainda pode-se encontrar a presença de pequenas quantidades de elementos $(<0,4 \%)$ como cálcio, magnésio, potássio, fósforo e sódio.

\subsubsection{Cristalinidade e Morfologia}

Fisicamente, muitos amidos são semicristalinos, possuindo cristalinidade de 20 - 45\%. A amilose e seus pontos de ligação com a amilopectina são regiões amorfas. As pequenas ramificações da amilopectina são a parte cristalina. As regiões cristalinas estão presentes na forma de duplas hélices, com comprimento de aproximadamente $5 \mathrm{~nm}$. Os segmentos da amilopectina que formam regiões cristalinas são paralelos ao eixo da hélice grande [19].

A cristalinidade se deve principalmente às partes lineares das cadeias de amilopectina. Por causa das forças intermoleculares as partes lineares da cadeia de amilopectina (que possuem estrutura de dupla hélice) se alinham de modo a formar micelas cristalinas. Essas micelas podem se organizar em lamelas isoladas ou na forma radial formando uma estrutura de anéis.

A Figura 5 apresenta os dois tipos de estruturas cristalinas encontradas na amilopectina. Uma é monoclínica (chamada de tipo A) e é encontrada em cereais. Já a outra é hexagonal (chamada de tipo B) e é encontrada em tubérculos. Existe também um padrão encontrado em sementes e raízes chamada de tipo $\mathrm{C}$, que acredita-se ser uma mistura dos tipos A e B [20]. 
Figura 5 - Estrutura cristalina da amilopectina: (a) monoclínica e (b) hexagonal. Os círculos pretos representam as moléculas de água constituintes da estrutura cristalina.

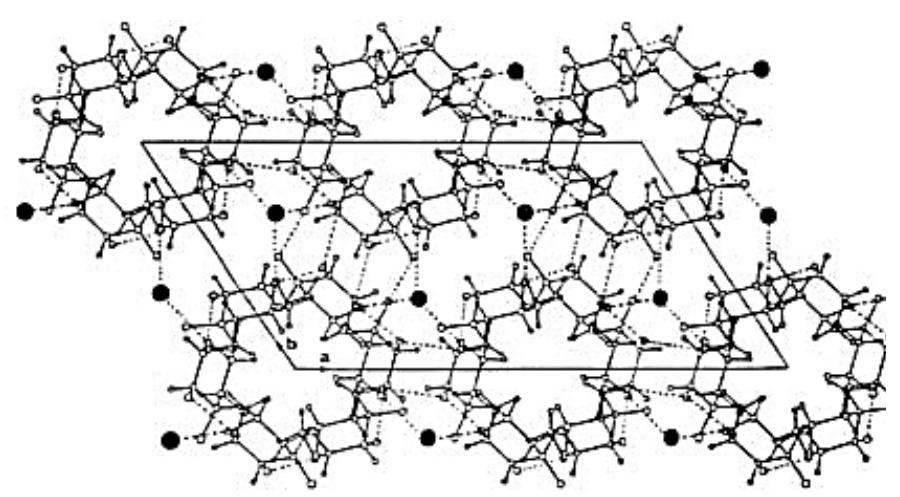

(a)

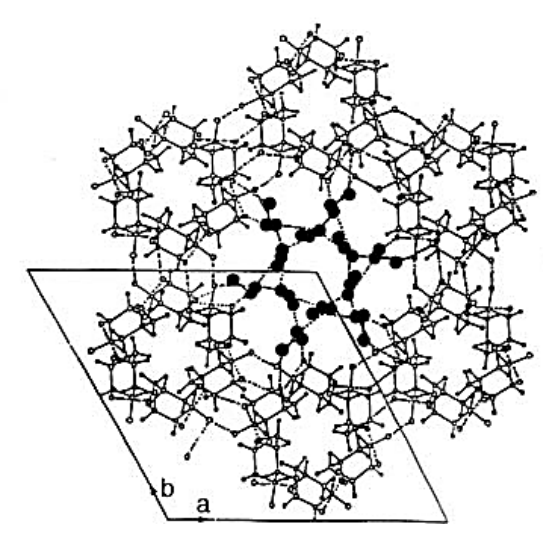

(b)

Fonte: [21]

$\mathrm{Na}$ Figura 6 (a) podem-se observar as lamelas cristalinas. Cada lamela tem o tamanho de aproximadamente $5 \mathrm{~nm}$ e o espaçamento entre os anéis observado é de 9 nm. A Figura 6 (b) mostra uma microscopia eletrônica de transmissão (MET) também evidenciando o crescimento radial das micelas cristalinas [21]. Também pode ser observada a cristalinidade na amilose. Durante o processo de gelatinização (o qual será abordado mais à frente nesse texto), com o aumento da temperatura as moléculas de amilose podem se ordenar em hélices simples formando cristais do tipo $\mathrm{V}[22]$.

Verificando a estrutura tanto da amilose quanto da amilopectina é possível notar a presença de grupos hidroxila $(-\mathrm{OH})$, com isso entende-se o porque do amido ser altamente hidrofílico. Em água fria o grânulo é insolúvel devido às fortes ligações de hidrogênio que mantêm as cadeias de amido unidas. Entretanto, na presença de água e aquecimento, a água é incorporada (absorção) na estrutura do grânulo. $O$ volume do grânulo expande de 10 a 100 vezes em volume, dependendo do tipo de amido (processo denominado de intumescimento) [23]. 
Dependendo da temperatura, a energia do sistema é suficiente para vencer as ligações de hidrogênio no interior do grânulo e ocorre perda da cristalinidade. As regiões amorfas são solvatadas e o grânulo incha rapidamente, podendo romper, e assim, muitas moléculas de amilose e amilopectina são lixiviadas para fora do grânulo, podendo se tornar completamente solúvel entre $130-150^{\circ} \mathrm{C}$.

Figura 6 - (a) MEV e estrutura esquemática do crescimento em anéis das lamelas cristalinas e amorfas na amilopectina. (b) MET de amido de milho ceroso (alto teor de amilopectina).
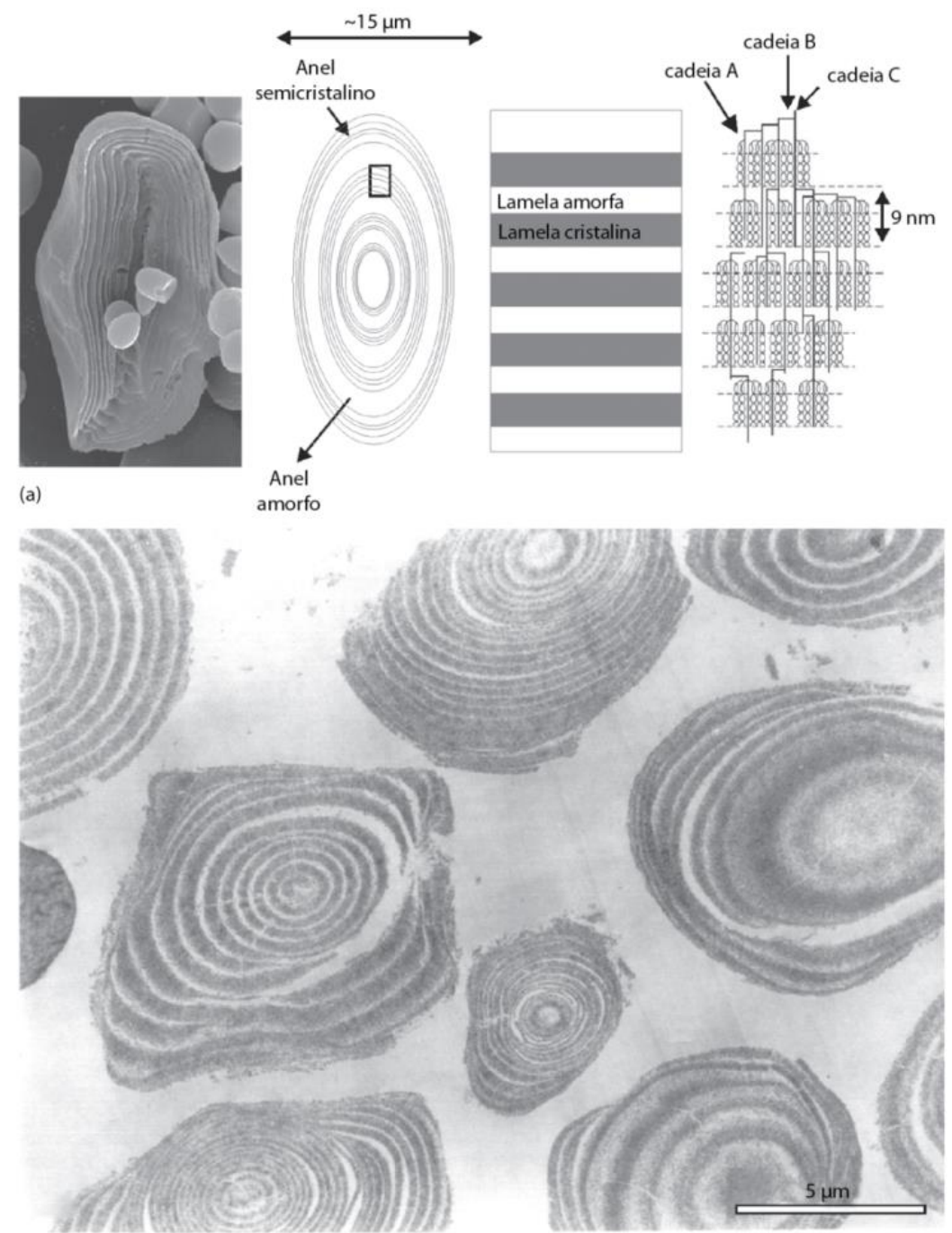

(b)

Fonte: Adaptado de [21] 
O tratamento térmico de polímeros a base de amido envolve múltiplas reações químicas e físicas, por exemplo: difusão da água, expansão dos grânulos, gelatinização, decomposição, fusão e cristalização. Estes grânulos do amido nativo possuem propriedades hidrofílicas, e, como sua temperatura de fusão está acima de sua temperatura de degradação, seu processamento é prejudicado.

A estrutura de grânulos do amido pode ser vista na Figura 7. Sabe-se que de acordo com a origem do amido tem-se grânulos com formatos e tamanhos diferentes, que variam de 2 a $100 \mu \mathrm{m}[23]$.

Figura 7 - Estrutura em grânulos do amido de (a) milho nativo, (b) trigo e (c) batata, (d) tapioca, (e) feijão e (f) arroz obtidas por MEV.

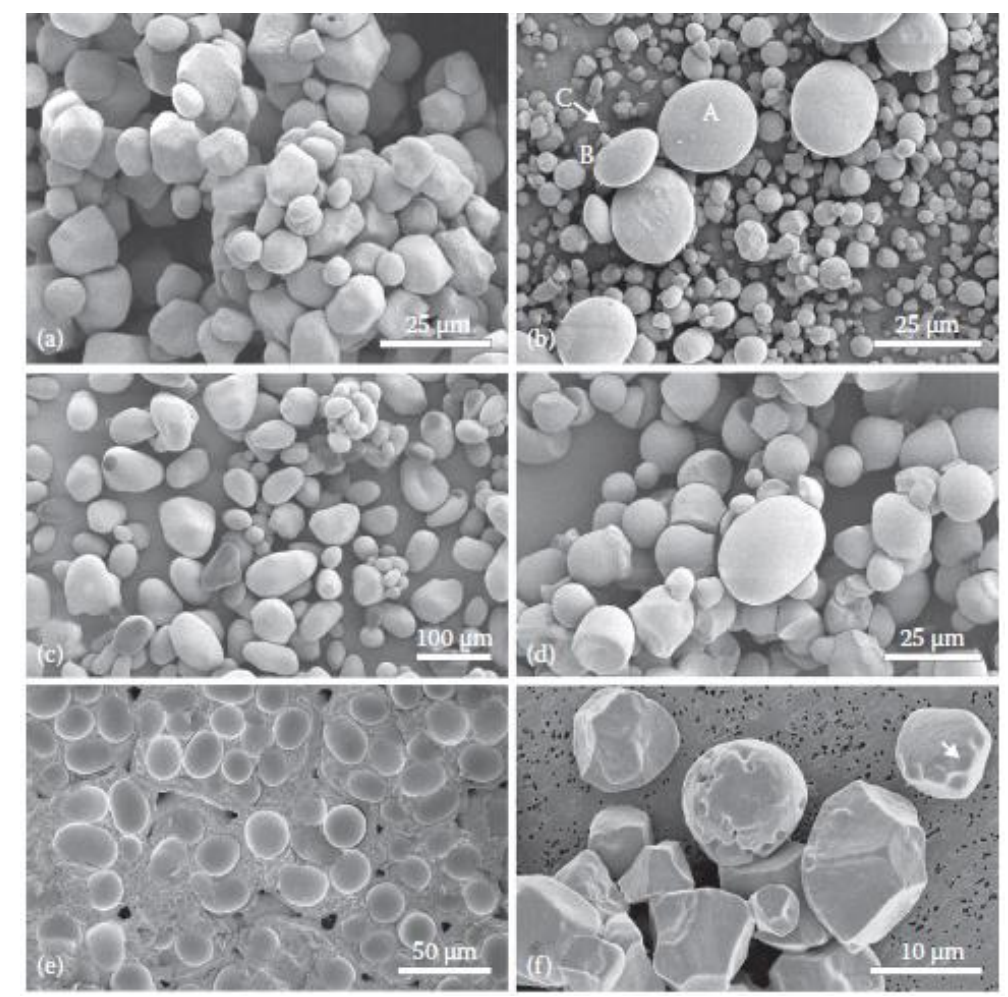

Fonte [21]

A Figura 8 apresenta a microscopia óptica com luz polarizada para um amido com alto teor de amilose e para o amido de feijão. Nota-se que sob a incidência de luz polarizada é possível observar padrões luminosos denominados cruz de malta. Isso ocorre devido à birrefringência gerada pela orientação radial das moléculas de amilose 
e amilopectina. Essas moléculas se alinham sob ação das ligações de hidrogênio, formando micelas cristalinas que crescem de forma radial, criando esferulitos. Logo, interferem na polarização da luz [23]. Na Figura 8 também é possível observar que o tamanho dos esferulitos é maior para o amido de feijão do que para um amido com alto teor de amilose. Isso evidencia que a molécula responsável pela cristalinidade do amido é a amilopectina.

Figura 8 - Microscopia óptica com luz polarizada mostrando o fenômeno cruz de malta para amido com alta amilose e para amido de feijão (figura inserida no canto inferior esquerdo).

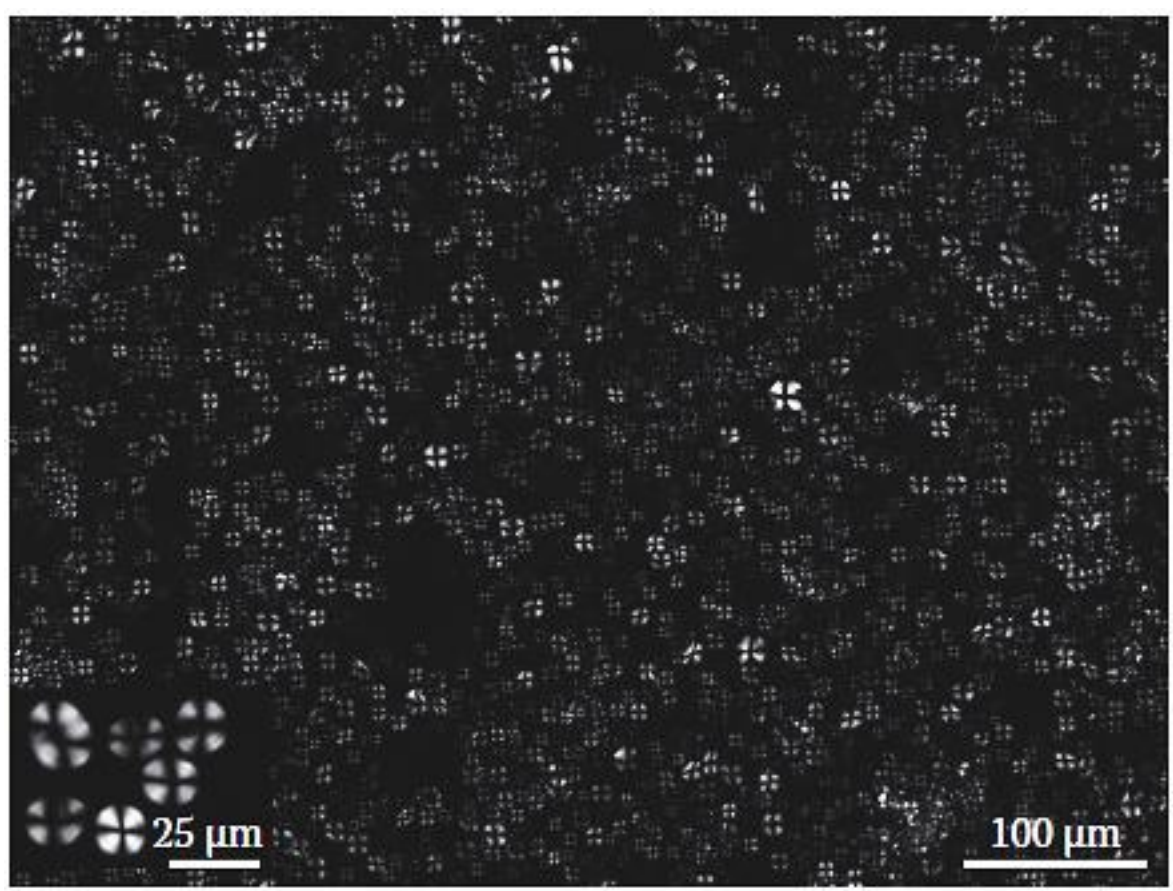

Fonte: [21]

\subsubsection{Biodegradação}

Existem diversas definições para biodegradação de polímeros. A ISO 472:2013 [24] define a biodegradação de plásticos como a perda de propriedades causada pela mudança na estrutura química. Já na norma ASTM D20.96 [25], a biodegradação em plásticos ocorre quando há quebra na cadeia polimérica. A Sociedade Japonesa de Plásticos Biodegradáveis propõe que ocorre biodegradação em plásticos somente quando há diminuição na massa molar do polímero [19]. 
Durante o processo de síntese biológica, através da respiração do microorganismo, ocorre a liberação de gás carbônico. Isto acontece tanto em microorganismos aeróbicos quanto em anaeróbicos, e os processos obedecem as reações descritas nas equações 1 e 2 , respectivamente. [9]

Biodegradação Aeróbica:

$$
\text { CPOLÍMERO }+\mathrm{O}_{2} \Rightarrow \mathrm{CO}_{2}+\mathrm{H}_{2} \mathrm{O}+\mathrm{C}_{\text {RESÍDUO }}+\mathrm{C}_{\text {BIOMASSA }}
$$

(Eq. 1)

Biodegradação Anaeróbica:

$$
\text { Cpolímero } \Rightarrow \mathrm{CO}_{2}+\mathrm{CH}_{4}+\mathrm{H}_{2} \mathrm{O}+\text { Cresíduo }_{\text {CBIomassa }}
$$

No caso específico do amido, a biodegradação ocorre pela hidrólise da cadeia polimérica, sob ação enzimática. Por ação das enzimas amilases, são quebradas as ligações $\alpha-1,4$ das cadeias de amilose e de amilopectina, como mostra a Figura 9.

Por ação das enzimas glicosídicas, são quebradas as ligações $\alpha-1,6$ presentes na amilopectina.

Figura 9 - Hidrólise do amido por ação enzimática da amilase.
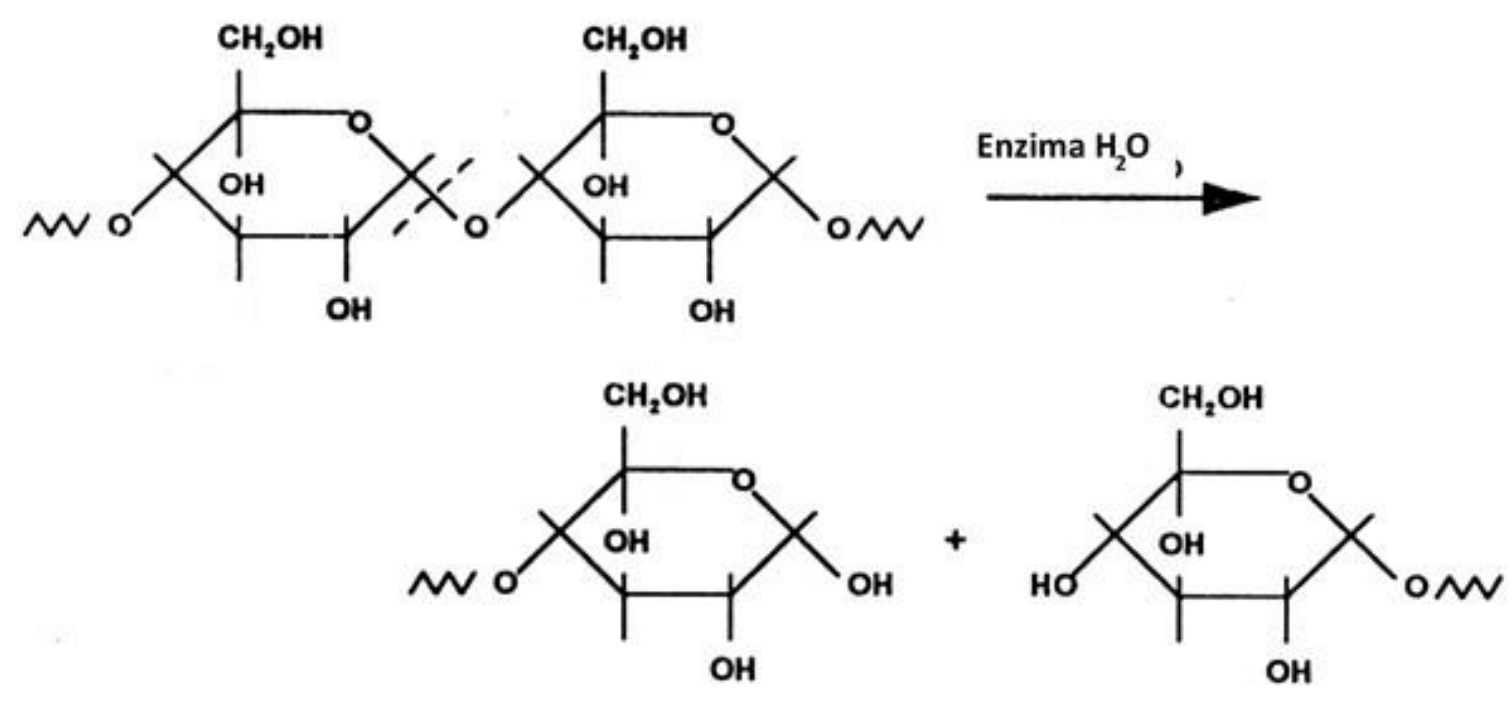

Fonte:[19] 


\subsubsection{Utilização do Amido}

Devido ao seu baixo custo e alta disponibilidade, o amido tem sido bastante estudado como matéria-prima para a indústria de plásticos. Neste contexto, o amido vem sendo modificado ou misturado com outras substâncias químicas para melhoria da sua processabilidade, formando uma família bastante versátil de bioplásticos.

Ao ser misturado com plastificantes, como água e glicerol, o amido torna-se um TPS, o qual possui propriedades de engenharia superiores ao amido e seu processamento torna-se viável, pois o amido puro possui uma temperatura de processamento acima da sua temperatura de degradação.

O amido ainda pode ser misturado ao polímero de formas distintas:

- Como carga, formando um compósito,

- Como TPS, obtendo-se uma blenda polimérica.

A mistura do amido com outros polímeros que possuam melhores propriedades de engenharia é um método mais rápido, versátil e menos custoso de se obter um produto com possibilidades de aplicação. Esta é uma alternativa conhecida, pois o estudo de blendas e de compósitos de polímeros convencionais com biopolímeros é alvo de diversas pesquisas há anos [26] [27].

Desta forma, a mistura de polímeros convencionais com biopolímeros é uma maneira de se minimizar a problemática causada pelo acúmulo de plásticos no meio ambiente, além das limitações de desempenho dos polímeros biodegradáveis.

Em alguns casos apenas o polímero biodegradável sofre decomposição, e o polímero sintético quebra-se em pedaços menores e é dissipado [28]. Em outras situações, a adição do biopolímeros pode contribuir para a quebra das moléculas do polímero não biodegradável [29].

Em blendas de polietileno (PE) com amido, foi visto que o consumo do amido pelos micro-organismos deixou buracos e poros na matriz de $\mathrm{PE}$, isso fez com que aumentasse a área superficial para a ocorrência de reações de oxidação e biodegradação [30][31]. 


\section{CAPÍTULO 3: AMIDO TERMOPLÁSTICO (TPS)}

\subsection{INTRODUÇÃO}

Este capítulo apresenta, primeiramente, uma revisão bibliográfica sobre o TPS. Em seguida descreve-se a parte experimental do estudo que teve como objetivo a obtenção e caracterização do TPS.

A parte experimental foi dividida em três etapas:

- Etapa I: Foi realizado um planejamento estatístico para otimizar a composição e a condição de processamento do TPS formado por amido de milho, água, glicerol e ácido cítrico;

- Etapa II: Baseado nos resultados da Etapa I, foram escolhidas 4 composições para se tornar possível um estudo complementar, e assim, analisar separadamente os efeitos do teor de água e de ácido cítrico, e da temperatura de processamento nas propriedades mecânicas do material;

- Etapa III: Com base nos resultados obtidos nas Etapas I e II, foi realizado o estudo do TPS com outros Ácidos Carboxílicos.

Destaca-se que alguns autores já realizaram estudos em filmes de TPS com ácido cítrico, tema central do estudo desenvolvido nas Etapas I e II. Entretanto, não se chegou a um consenso sobre qual seria a composição ótima. Além disso, há a necessidade de analisar o uso de outros ácidos carboxílicos, e assim estudar a influência da estrutura desses ácidos no TPS (tema desenvolvido na Etapa III).

\subsection{REVISÃO BIBLIOGRÁFICA}

O amido pode se tornar um material termoplástico pela adição de um plastificante, como água, álcool e glicerina. O produto resultante é o amido termoplástico (TPS), que consiste em um polímero biodegradável [22][32]. 


\subsubsection{Gelatinização}

O termo gelatinização refere-se à destruição da fase cristalina dos grãos de amilose, sendo um processo irreversível, que inclui inchaço granular, fusão cristalina nativa (perda de birrefringência) e solubilização molecular.

Quando o amido entra em contato com a água fria, os grânulos incham ligeiramente (10 a 20\%), devido à difusão e absorção de água nas regiões amorfas, e este processo é reversível. Porém quando os grânulos são aquecidos em água, eles incham irreversivelmente. Ocorrendo o fenômeno denominado gelatinização, no qual há perda da organização estrutural, com fusão dos cristais.

A medida que os grânulos continuam se expandindo, ocorre lixiviação da amilose da fase intergranular para a fase aquosa, resultando num aumento da viscosidade do sistema. Com a gelatinização há aumento da viscosidade do meio, podendo atingir seu valor máximo na Tgel (temperatura de gelatinização), na qual os grânulos são totalmente quebrados e as regiões cristalinas desaparecem.

O teor de plastificante, a temperatura de processamento, a velocidade de rotação dos rotores e a natureza do amido exercem grande influência no comportamento reológico, durante o processamento do amido.

A Figura 10 mostra a curva do torque em função do tempo em um misturador de câmara interna para o TPS, e, a Figura 11 mostra as fases de transição do amido durante o processo de plastificação em um misturador de câmara interna. A estrutura cristalina dos grânulos de amido é destruída durante o aquecimento da água (a e b). Durante a gelatinização, a amilose e a amilopectina são parcialmente separadas, mas com um menor teor de água no amido, essa separação pode ser impedida.

No entanto, a tensão de cisalhamento pode aumentar o processo de separação, a amilose pode ser parcialmente lixiviada para fora da amilopectina. Em um sistema de amido com $10 \%$ de umidade, a maioria da amilose continua na amilopectina.

A amilopectina gelatinizada inicialmente está em estado amorfo, pois a estrutura cristalina helicoidal dupla formada pelas cadeias curtas e ramificadas de amilopectina se dilaceraram durante a gelatinização. Entretanto, as cadeias 
permanecem em padrão regular. As cadeias ramificadas curtas da amilopectina se entrelaçam formando pequenos corpos esféricos, "bolas de géis" que são menores do que as cadeias lineares.

Figura 10 - Variação típica do torque em função do tempo de mistura, em um misturador de câmara interna, para o TPS.

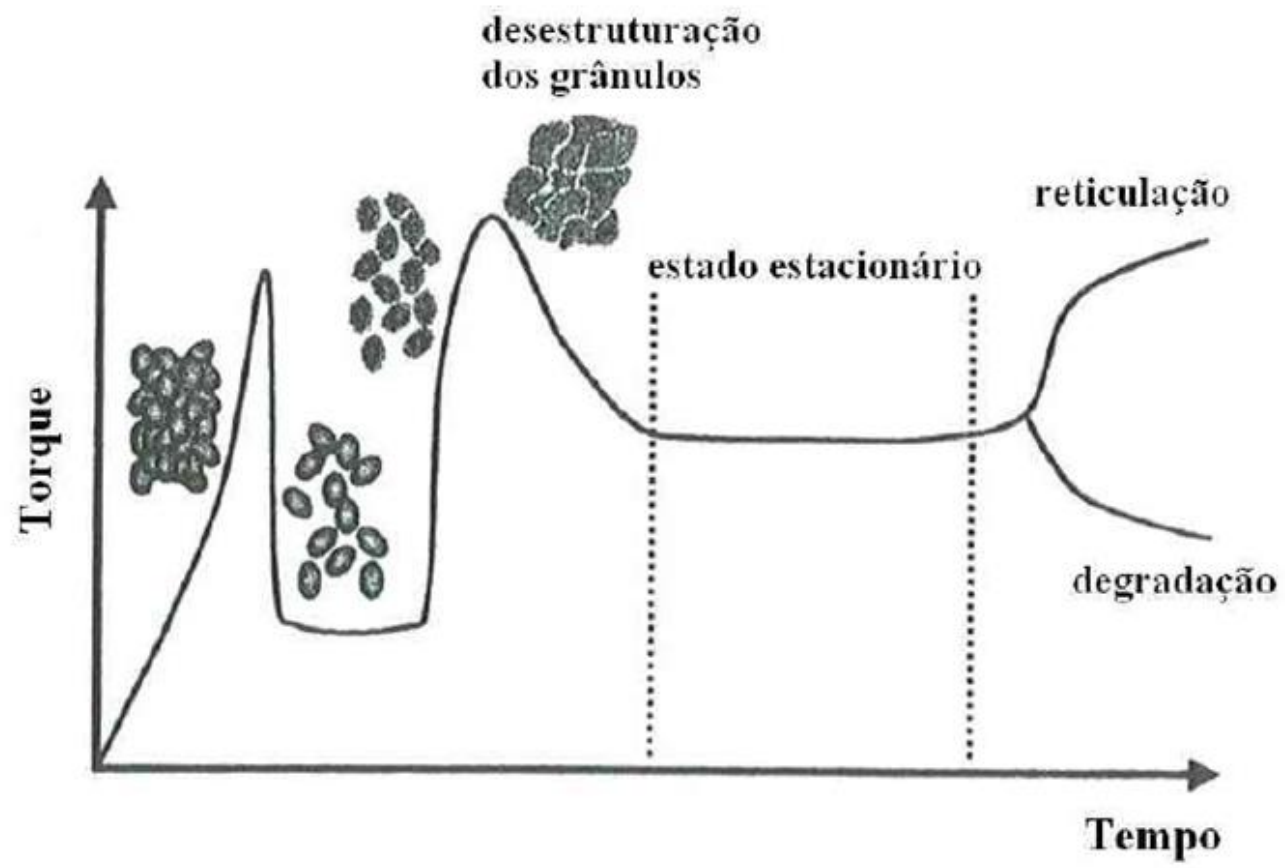

Fonte:[33]

Apesar da amilopectina imediatamente após a extrusão ser amorfa, já foram encontrados cristais de hélice simples, do tipo-V. Esta cristalinidade inicial resulta em maior módulo e limite de elasticidade para materiais ricos em amilose. A cristalinidade do tipo-V aumenta com o tempo [33] [34].

Quando não há cisalhamento, o processo de gelatinização depende principalmente do teor de água e da temperatura. Durante a fase inicial do processamento térmico, quando a temperatura aumenta de $20^{\circ} \mathrm{C}$ para $60^{\circ} \mathrm{C}$, a água penetra nas moléculas de amido. Neste momento, o amido granular ainda permanece com sua estrutura estável, e, as moléculas constituintes se mantêm em forma de esferulitos, devido às forças de Van der Waals ou ligações de hidrogênio. Desta forma, 
os grânulos ainda exibem uma birrefringência, quando observados sob luz polarizada, porque grande parte dos seus componentes cristalinos permanecerem intactos. A temperatura neste estágio é dita "temperatura inicial de gelatinização" [33] [34].

Figura 11 - Representação esquemática das fases de transição do amido durante o processamento térmico.

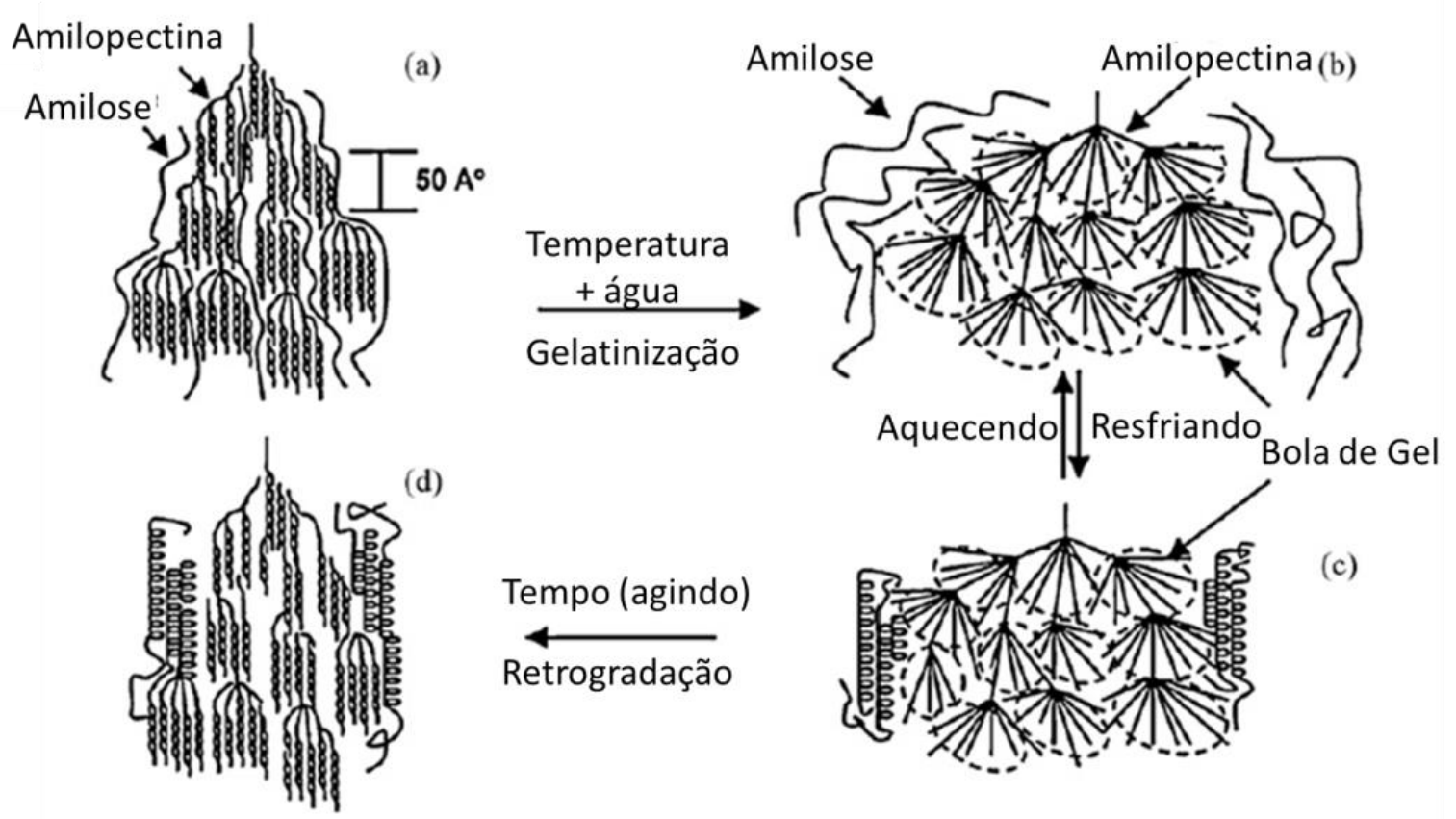

Fonte: [34]

Quando uma suspensão de amido aquosa é aquecida além da sua temperatura de gelatinização, ligações de hidrogênio são rompidas e se ligam aos grupos hidroxila das moléculas de água, resultando em maior inchaço e dissolução dos cristalitos. Durante este tempo, todas as duplas hélices de amilopectina se dissociam, mas a estrutura granular inchada, é mantida até que a suspensão seja novamente submetida a uma temperatura elevada [33] [34].

A gelatinização completa do amido sem processamento (sem cisalhamento) exige água em excesso (>67\%). No entanto, se a concentração de água for muito elevada, os cristalitos de amido podem ir além do inchaço e se romperem, logo, não irão fundir em altas temperaturas. 
Mas, se a concentração de água for limitada, o inchaço pode não ser significativo, e com isso não ocorrerá a completa gelatinização no intervalo de temperatura usual. Caso ocorra aumento da temperatura, os grânulos de amido tornam-se progressivamente mais maleáveis e podem, eventualmente, fundir. Desta forma, espera-se que o amido exiba um comportamento viscoelástico, como o de um termoplástico fundido. O processo de gelatinização em misturas com baixa umidade pode ser definida como "fusão". A pressão também pode influenciar no comportamento de gelatinização/ fusão do amido [33] [34].

Como o processamento em uma extrusora envolve alto cisalhamento e alta temperatura, a gelatinização é alcançada com baixos teores de umidade, uma vez que a força de cisalhamento fisicamente "rasga" os grânulos de amido, permitindo uma transferência de água mais rápida para as moléculas interiores. Por consequência, durante a extrusão, a perda da cristalinidade não é causada pela penetração de água, mas pelo rompimento das ligações moleculares, devido ao cisalhamento intenso no interior da extrusora [33] [34].

Durante a extrusão com baixa umidade ocorrem, simultaneamente, os seguintes eventos: pequenas quantidades de amido gelatinizado e fundido, e a fragmentação de amido (também degradação ou decomposição) [33] [34].

A energia mecânica e térmica transferida para o amido durante a extrusão afetam as quebras de ligações de valência primárias e secundárias, e as ligações de hidrogênio entre as moléculas do amido. Esta mudança na estrutura aumenta a susceptibilidade do amido à ação de enzimas, reduzindo as ligações de hidrogênio e aumentando as hidroxilas livres.

A extrusão pode afetar muito mais a amilopectina do que a amilose, sendo em ambas, a massa molar uma das propriedades mais afetadas. Os principais objetivos das técnicas de processamento são fundir e misturar, e os parâmetros devem ser ajustados para minimizar a degradação da cadeia.

Durante o processamento sob cisalhamento, a fragmentação do amido é inevitável. O grau de fragmentação depende do tipo de amido e das condições de operação, como: temperatura, velocidade da rosca e umidade. 
O grau de fragmentação da amilopectina diminui nas seguintes situações: com a redução da velocidade da rosca (80 - $120 \mathrm{rpm}$ - rotações por minuto), com o aumento da temperatura $\left(121-177^{\circ} \mathrm{C}\right)$ e com redução do teor de umidade (20 - 30 \%). Com o aumento do teor de glicerol ocorre redução da degradação do amido.

\subsubsection{Retrogradação}

Quando o amido gelatinizado é armazenado e mantido a temperatura ambiente, ele pode sofrer um fenômeno denominado retrogradação. Com o passar do tempo, as moléculas do amido vão perdendo energia e as de hidrogênio tornam-se mais fortes, assim, as cadeias começam a reassociar-se num estado mais ordenado. Esta reassociação culmina na formação de simples e duplas hélices, resultando na formação de zonas de junção entre as moléculas, formando áreas cristalinas. Como a área cristalizada, o índice de refração altera, o material vai se tornando mais opaco a medida que a retrogradação acontece [35].

A amilose que foi exudada dos grânulos inchados forma uma rede, por associação, com as cadeias que rodeiam os grânulos gelatinizados. Como consequência, a viscosidade aumenta, convertendo-se num sistema viscoelástico, com aspecto turvo, ou para concentrações de amido suficientemente altas $(>6 \%$ em massa), num gel elástico, com aspecto opaco. Em determinadas ocasiões pode ocorrer a precipitação de cristais insolúveis de amido, levando a separação de fases.

A forte interação das cadeias de amido força a saída da água do sistema. A retrogradação é um fenômeno complexo e depende de muitos fatores como: temperatura de armazenamento, tempo, $\mathrm{pH}$, fonte de amido, presença de outros componentes e condições de processamento [35].

\subsubsection{Plastificantes}

O amido natural apresenta ponto de fusão acima de sua temperatura de degradação, sendo assim, durante o processamento é necessário adicionar um 
plastificante para diminuir sua temperatura de fusão $\left(T_{m}\right)$ e para aumentar a flexibilidade do polímero.

Ao adicionar ao polímero um plastificante as moléculas deste penetram na fase polimérica, difundindo-se entre as macromoléculas do polímero e aumentando a mobilidade entre as cadeias (interação física). Esta interação pode ocorrer devido a maior liberdade do movimento das macromoléculas, e, da formação de cristalitos do material plastificado, que podem atuar como reticuladores físicos, modificando as propriedades do material (queda do alongamento e aumento do módulo de elasticidade).

Desse forma, os plastificantes alteram a temperatura de transição vítrea $\left(T_{g}\right)$, a $T_{m}$ e as propriedades mecânicas de um polímero, pois reduzem ou até neutralizam as forças de interação intermoleculares, mas não alteram a natureza química do polímero.

Dependendo da concentração empregada de plastificante no amido, pode ocorrer um efeito chamado antiplastificante, isto é, ao invés de aumentar a flexibilidade e hidrofilicidade, podem causar um efeito contrário. Geralmente isto ocorre quando são empregadas pequenas concentrações de plastificante (por exemplo, abaixo 20 g/100 amido). E então, o plastificante interage com a matriz polimérica mas não está em quantidade suficiente para aumentar a mobilidade molecular. Este fenômeno também dependente das condições de armazenamento, e, as propriedades mecânicas são deterioradas [28].

A combinação adequada de plastificantes pode melhorar as vantagens e eliminar algumas desvantagens do seu uso. Por exemplo: a mistura dos plastificantes ureia e etanolamina na formação do TPS, pode facilitar a formação de ligações de hidrogênio mais fortes e estáveis entre as moléculas de amido. Dessa forma, como as ligações são mais intensas, pode-se evitar que a ureia saia do material com o passar do tempo, evitando a deteriorização das propriedades mecânicas do material [36][37].

Alguns açúcares, como a glicose, frutose e sacarose, foram utilizados como um segundo plastificante em combinação com o glicerol e o amido para a formação do TPS, influenciando nas propriedades mecânicas e na cristalinidade. Entretanto, as 
ligações de hidrogênio formadas não foram fortes o suficiente, e, em 90 dias notou-se a mudança da cristalinidade [38].

Outros plastificantes utilizados no processamento do amido para a obtenção do TPS são: glicerol, sorbitol, ácido lático, etilenoglicol, dietilenoglicol, polietilenoglicol (PEG), diacetato, triacetato [39-41].

Alguns lubrificantes como óleos vegetais, estearato de magnésio, estearato de cálcio, elastômeros fluorados e líquidos iônicos estão sendo utilizados para melhorar as propriedades de processamento, mas ainda não foi obtido um resultado satisfatório [42][43].

Os principais plastificantes empregados em amido são água, glicerol, anidrido maleico que estão listados nos subitens a seguir. Além destes, também são descritos os ácidos carboxílicos utilizados como plastificantes secundários neste trabalho.

\subsubsection{1 Água}

A água é o plastificante mais utilizado, porém para obter propriedades mecânicas satisfatórias e minimizar a retrogradação precisa ser combinado com outros plastificantes.

No entanto, a água é de grande valia na preparação do TPS, pois ao adicionar água, ocorre um inchaço dos grânulos de amido, aumentando a viscosidade durante o processamento. $O$ cisalhamento imposto no processamento quebra estes grânulos em fragmentos menores, resultando numa queda da viscosidade.

Esta diminuição da viscosidade pode ser maior ainda quando outros aditivos são misturados ao amido e a água. Oteniente et al. [44] processaram amido de trigo com $10 \%$ em massa de glicerol e $2 \%$ em massa de óleo de linhaça epoxidado e relataram queda da viscosidade com o aumento do teor de umidade. Além disso, a viscosidade do amido fundido decresce exponencialmente com o teor de água, quando o conteúdo de glicerol aumenta [45].

É bem conhecido que polímeros possuem comportamento pseudoplástico, que pode ser modelizado pela lei de potência, apresentada na Equação 3: 


$$
\eta=K \dot{\gamma}^{n-1}
$$

(Eq. 3)

Onde $\eta$ é a viscosidade, $\dot{\gamma}$ é a taxa de deformação, $\mathrm{K}$ é consistência e $\mathrm{n}$ é índice da lei de potência. Para fluido pseudoplástico $n<1$.

No caso do TPS, quanto ao n (índice da lei de potência) não há uma relação consistente com o teor de água. Alguns autores relatam que há um aumento de $\mathrm{n}$ com o aumento da unidade molecular, outros não veem relação significativa entre estes parâmetros e outros autores ainda observam um efeito reverso [22].

Além disso, durante o processo de obtenção do termoplástico, a água do amido e o plastificante são importantes, pois os plastificantes podem formar ligações de hidrogênio com o amido.

\subsubsection{Glicerol}

Como descrito no item 3.3.2.1, além de se adicionar água, pode-se adicionar glicerol para plastificar o amido. O glicerol, ou propano-1,2,3-triol, ainda chamado comercialmente de glicerina, é um álcool com 3 hidroxilas, como mostra a Figura 12.

Figura 12 - Representação da estrutura química do glicerol.

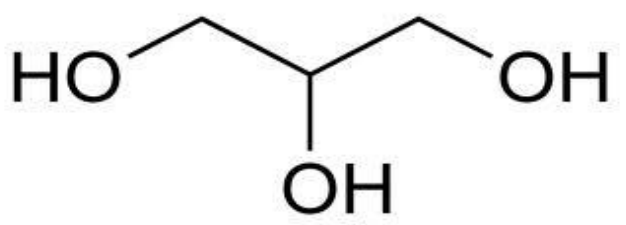

Fonte: [46]

Ao analisar na literatura os resultados dos comportamentos reológicos em relação ao teor de glicerol no TPS, estes novamente não são consistentes. Alguns autores reportam um aumento da viscosidade com o aumento do teor de glicerol, outros reportam que o $n$ teve uma queda significativa quando foi utilizado o glicerol 
como coagente plastificante com a água. Isto mostra que a relação entre $n$ e o conteúdo de glicerol é bem complexa e depende de vários fatores [47].

Analisando amidos de diferentes fontes, verificou-se que o glicerol tende a diminuir a $T_{g}$ e estreitar a região de transição dos amidos extrudados. Com até $25 \%$ em massa de glicerol a $T_{g}$ não baixou de $20{ }^{\circ} \mathrm{C}$, pois o teor de plastificante ébaixo, pensando apenas na existência de glicerol como plastificante. Sabe-se que quanto menor a $T_{g}$, maior o aumento na resistência ao impacto, entretanto com 15 a $25 \%$ em massa de glicerol este aumento da resistência é pequeno. Ao analisar algumas propriedades mecânicas, foi visto que ao aumentar o teor de glicerol, o módulo e a resistência à tração diminuem, enquanto o alongamento aumenta [47].

\subsubsection{Anidrido Maleico}

O anidrido maleico é um plastificante sintético, utilizado e descrito por diversos autores. Sua estrutura química pode ser vista na Figura 13.

Figura 13 - Representação da estrutura química do anidrido maleico.

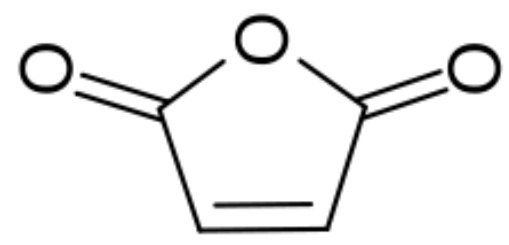

Fonte: Adaptado [48]

Foi visto que: ao adicionar 2,5\% em massa de anidrido maleico em uma mistura amido/glicerol (80/20) há queda nos valores de viscosidade e de massa molar do TPS, bem como a quebra da estrutura do amido durante a extrusão [49]. 


\subsubsection{4 Ácidos Carboxílicos}

Alguns ácidos carboxílicos podem ser utilizados como aditivo secundário para o glicerol presente no TPS e em blendas poliméricas de TPS com outros polímeros termoplásticos.

a) Ácido Cítrico (AC)

O ácido cítrico, também conhecido como citrato de hidrogênio, ou ácido 2hidroxi-1,2,3-propanotricarboxílico, é um ácido orgânico fraco de fórmula $\mathrm{C}_{6} \mathrm{H}_{8} \mathrm{O}_{7}$, encontrado no estado sólido, em temperatura ambiente, de cor branca ou translúcida, inodoro, de sabor azedo, completamente solúvel em água, biodegradável, de baixo ponto de fusão, atóxico, não inflamável e é encontrado no organismo de diversas plantas, como os citrinos [50] [51].

Este ácido é isolado de frutas cítricas e obtido pelo processo de fermentação de sacarose, realizada pelo fungo Aspergillus niger ou pela levedura Candida lipolytica, utilizando como matéria-prima o melaço de cana de açúcar ou a dextrose. Tal processo dá origem ao ácido cítrico líquido, que, posteriormente, é purificado, assumindo a forma sólida. Seu teor de acidez se deve à presença de 3 carboxilas na cadeia carbônica, sendo classificado, portanto, como um ácido tricarboxílico, como mostra a Figura 14 [50] [51].

Trata-se do ácido mais utilizado pela indústria alimentícia e de bebidas, uma vez que apresenta propriedades antioxidantes, acidulantes, flavorizantes, sequestrantes e reguladoras de acidez.

É uma substância que pode ir ao meio ambiente sem que haja significativos impactos ambientais desfavoráveis. 
Figura 14 - Representação da estrutura química do ácido cítrico.

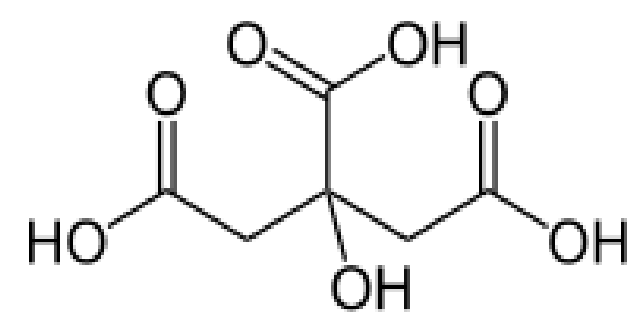

Fonte:[52]

O ácido cítrico já tem sido utilizado como aditivo secundário para o glicerol no TPS [53][54][55][56][57][58]. Ele pode ter as seguintes funções:

- Formar anidrido e ligações cruzadas: ao aquecer o ácido cítrico a uma temperatura acima do ponto de ebulição da água, este pode sofrer desidratação, ou seja, pode perder uma molécula de água, formando um anidrido. Ao aquecer ainda mais pode ocorrer uma maior desidratação, formando em seguida uma ligação cruzada [59], como mostra a Figura 15 ;

- Retardar a cristalização, ou retrogradação: o ácido cítrico interage mais fortemente com o grupo C-O do amido do que o glicerol. Logo, podem ser formadas ligações cruzadas que limitam a mobilidade das moléculas de amido, diminuindo a quantidade de ligações de hidrogênio entre os grupos hidroxila do TPS no estado amorfo. Dessa forma irá ocorrer uma queda na difusão da água entre as macromoléculas do amido. Com isso, pode-se retardar a retrogradação. [55,58,60-75];

- A acidez do ácido cítrico possui as seguintes funções:

- Facilitar a queda da viscosidade devido à hidrólise (Figura 16);

- Auxiliar na deterioração dos emaranhados da cadeia de amido e no enfraquecimento da interação entre as moléculas de amido [69][71], - Ajudar a promover a glicosidação na presença de glicerol, como mostra a Figura 16, onde ocorre a formação de glicosídeos derivados da reação entre o glicerol e o carbono anométrico do anel de glicose [77]; 
Figura 15 - Reações que podem ocorrer durante o aquecimento entre 0 amido e 0 ácido cítrico.

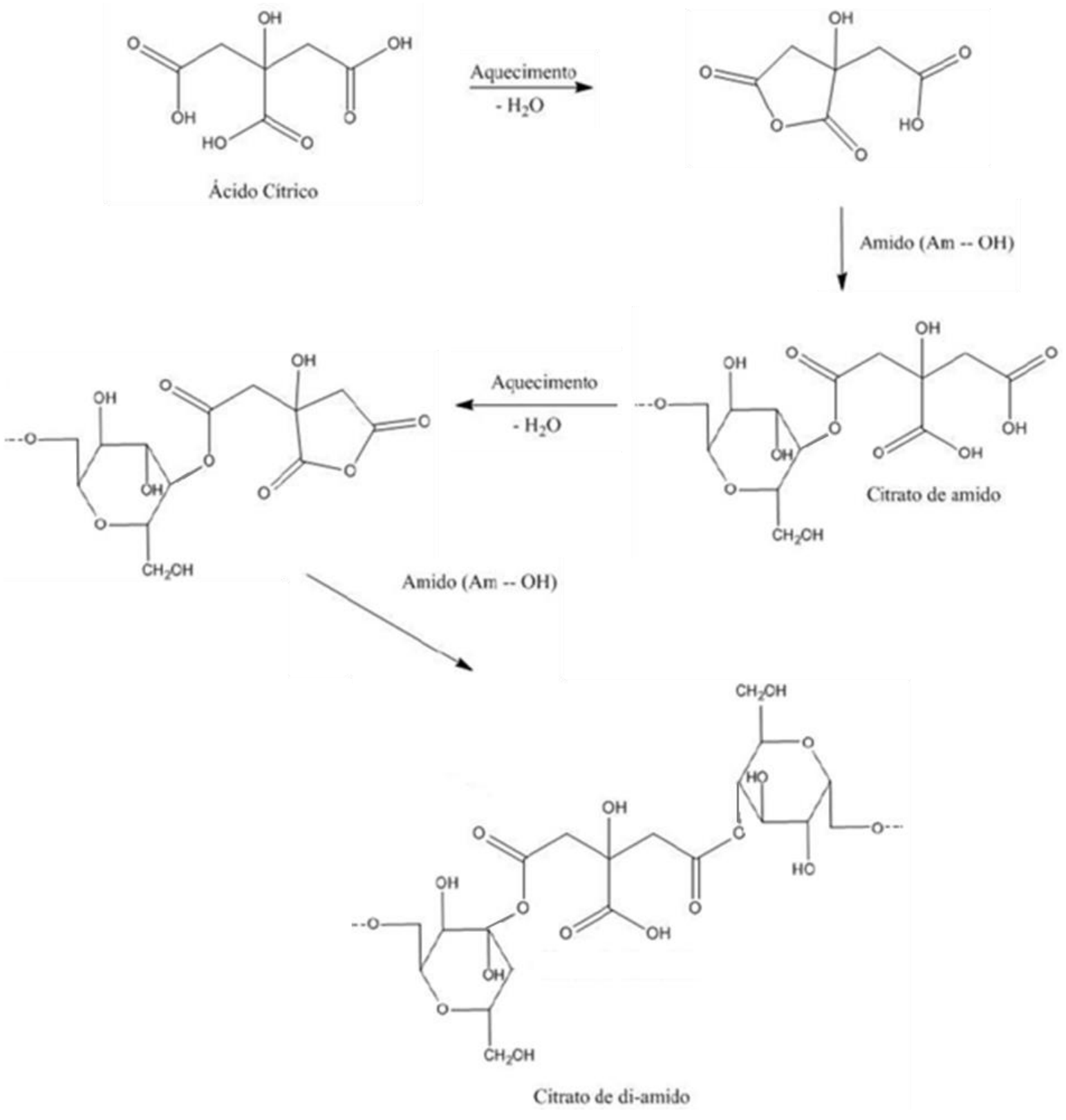

Fonte: Adaptado de [59] e [77]

- Diminuir a viscosidade do TPS: ao aumentar o teor de ácido cítrico há uma queda na viscosidade, mas isso ocorre até um limite de composição, que é aproximadamente $20 \%$ em massa de ácido cítrico [22] [61]; 
- Atuar como plastificante: o ácido cítrico residual livre pode atuar como plastificante, enfraquecendo as ligações de hidrogênio entre as cadeias de amido. Mas o excesso pode contribuir para a aderência do material nas superfícies metálicas dos equipamentos durante o processamento, prejudicando a processabilidade [53][54][55][50];

Figura 16 - Reação de Hidrólise.
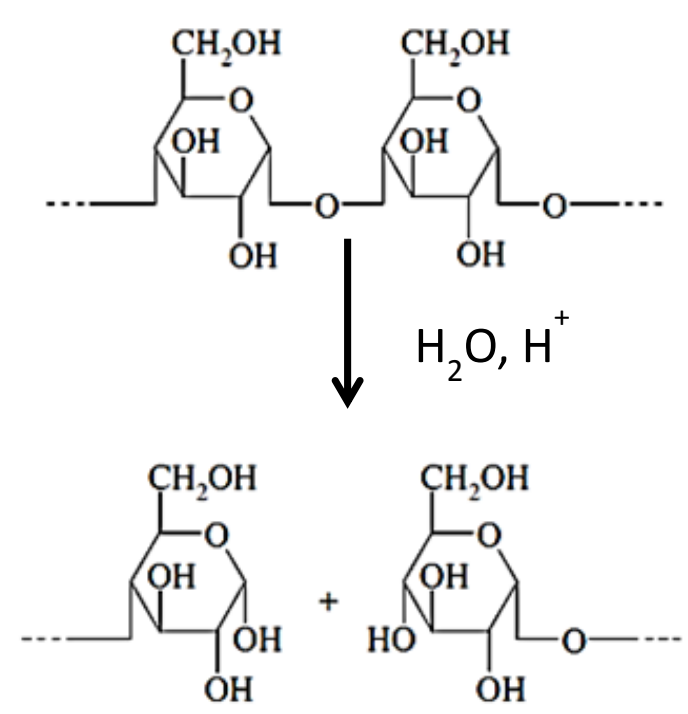

Fonte: Adaptado de [77]

- Modificar as propriedades mecânicas do TPS: Para Reddy e Yang [77] concentrações de ácido cítrico abaixo de $5 \%$ em massa provocam poucas melhorias na resistência do material, uma vez que não há formação de ligações cruzadas suficientes; mas para concentrações acima de $5 \%$, ocorre um excesso de ligações cruzadas que limitam a mobilidade das cadeias, causando queda nos valores de alongamento. As ligações formadas entre o amido e o glicerol (Figura 17), podem reduzir ou até mesmo impedir a aproximação das cadeias polimérica. Dessa forma, a resistência à tração diminui ligeiramente ao aumentar a 
concentração de ácido cítrico. Isto indica que o ácido cítrico promove reticulação, que representa a redução da flexibilidade do filme;

Figura 17 - Glicosidação do amido.
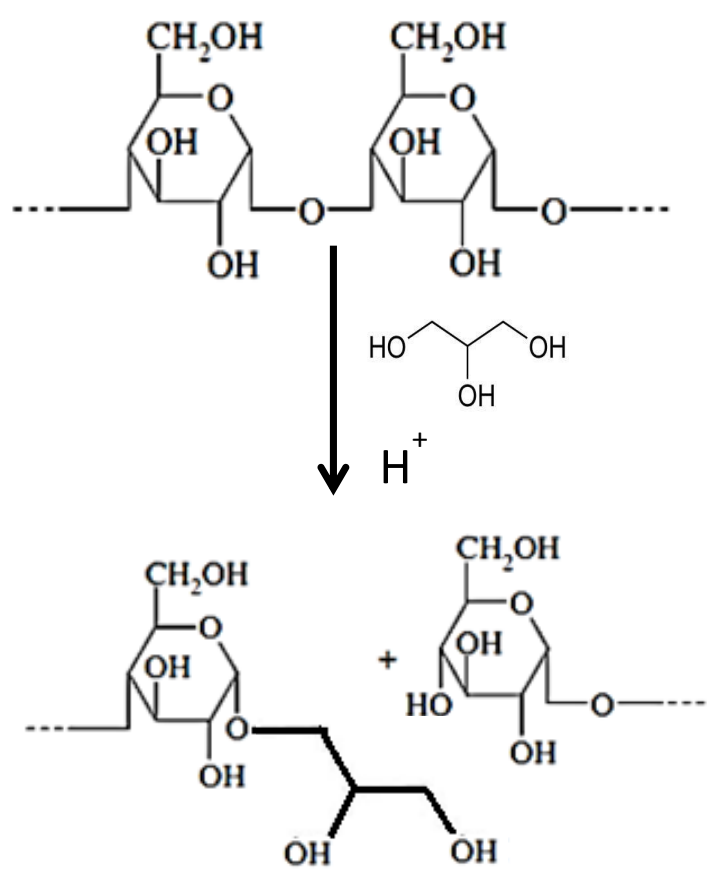

Fonte: Adaptado de [77]

- Realizar uma reação de esterificação com o amido, monoéster (Figura 18), a partir da reação com as hidroxilas presentes na cadeia. Isso faz com que se reduzam as forças inter e intramoleculares, permitindo uma maior plastificação do amido;

- Influenciar o comportamento reológico: devido à quebra das moléculas, o ácido cítrico influencia fortemente o comportamento reológico, diminuindo a viscosidade aparente. Foi visto que $n$ e $K$ (Equação 3 - Lei de potência) diminuem com o aumento do teor de ácido $[74,75,78]$; 
Figura 18 - Reação de Esterificação entre amido e ácido cítrico.

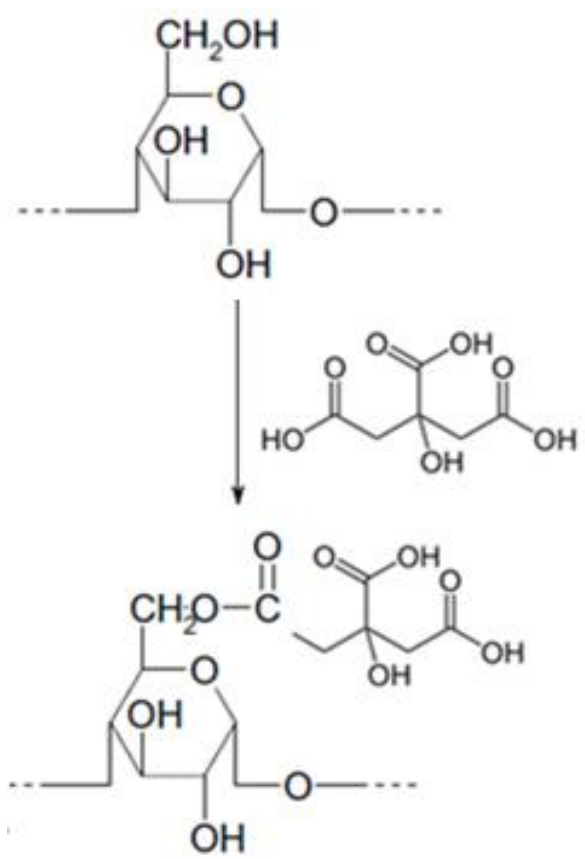

- Aumentar a faixa de temperatura utilizada durante o processamento de plastificação do amido-glicerol: o ácido cítrico também foi utilizado para aumentar a faixa de temperatura utilizada durante o processamento de plastificação do amido-glicerol, ocasionando a redução na $T_{m}$ do TPS. Isto ocorre porque o ácido cítrico reduz os valores da energia de ativação do amido de milho e do glicerol quando plastificados em relação ao amido seco, tornando-os menos sensíveis a temperatura de processamento, como mostra a Equação de Arrhenius (Equação 4). Por outro lado, a variação de $k$ com o teor de ácido depende da formulação. Para o amido-glicerol hidratado, o $k$ diminui com o aumento do ácido, o que significa que o ácido deixa o TPS mais sensível ao cisalhamento. No entanto, a tendência reversa é observada para o amido-glicerol seco, pois pode formar fortes ligações que enfraquecem a interação das moléculas de amido, facilitando o movimento entre as moléculas. Outra razão para haver a mudança do $k$ pode ser acidólise do amido na presença do ácido (Figura 19) 


$$
k=A e^{\left(\frac{E_{n}}{R T}\right)}
$$

(Eq. 4)

Onde $k$ é a velocidade da reação, $E_{n}$ é a energia de ativação, $R$ é a constante dos gases $(8,31 \mathrm{~J} / \mathrm{mol} . \mathrm{K})$ e T é a temperatura em Kelvin.

Figura 19 - Reação ácido cítrico com amido e glicerol - Hidrólise ácida ou Acidólise.

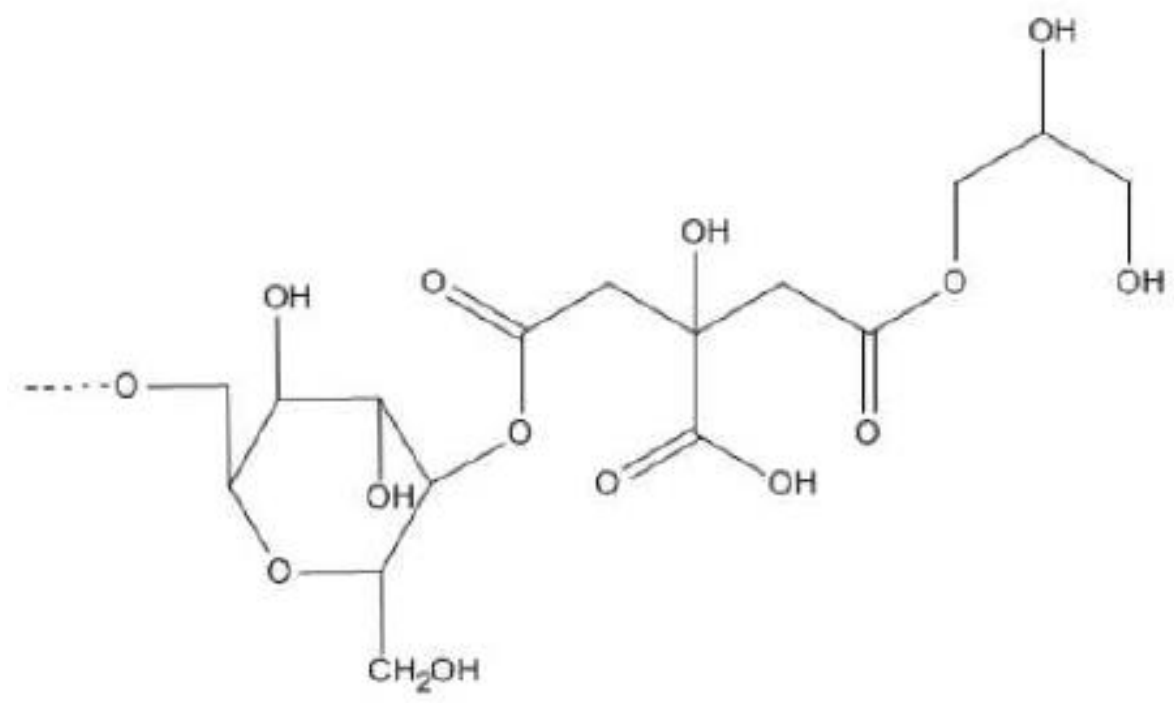

Fonte: [77]

- Aumentar a temperatura de degradação do amido: pois pode formar fortes ligações de hidrogênio com o amido e o glicerol. Portanto, melhora a adesão entre ácido cítrico, glicerol, água e amido. A acidólise, provavelmente, irá ocorrer como uma reação secundária, mas em pequena concentração, caso contrário ocorreria à queda da estabilidade térmica;

- Modificar a aparência do material: notou-se que quando o amido de mandioca foi misturado com diferentes teores de glicerol e ácido cítrico foram obtidas diferentes formas do material. A mistura mais interessante foi com 7,5\% em massa de glicerol e 0,5\% em massa de ácido cítrico, a qual formou uma estrutura diferente da observada tradicionalmente em TPS, similar a um donut. Isto evidencia o fenômeno de reticulação entre 
o ácido cítrico e o amido, dentro do granulo, que pode ser responsável pela rugosidade encontrada no material [77];

- Melhora a resistência à água do TPS.

b) Ácido Adípico (AA)

O ácido adípico é um ácido dicarboxílico (apresenta duas carboxilas em sua estrutura), nomeado oficialmente de ácido hexanodióico. É representado pela fórmula química $\mathrm{C}_{6} \mathrm{H}_{10} \mathrm{O}_{4}$ e sua estrutura é representada na Figura 20. É um material inodoro e seus cristais são brancos. Este ácido é mais denso que a água, e é solúvel em solventes orgânicos como o álcool e a acetona. O nome adípico vem do vocábulo latim adipem, que significa "uma gordura". O ácido adípico é obtido através da reação de oxidação do ciclohexanol ou ciclohexanona com ácido nítrico, tendo o cobre e o vanádio como agentes catalisadores [79].

Figura 20 - Representação da estrutura química do ácido adípico.

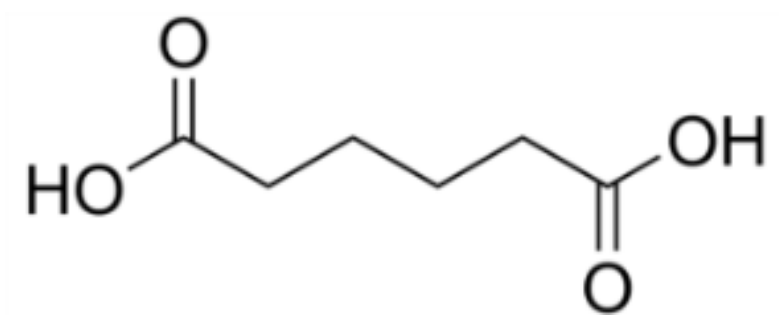

Fonte: [80]

$\mathrm{Na}$ indústria química, o ácido adípico possui grande importância, especialmente na produção do Náilon, que é uma poliamida. $O$ ácido adípico também é matéria-prima para a produção de poliésteres, reagindo, por exemplo: com éteres como etilenoglicol, com o principalmente intuito de se obter polímeros flexíveis para espumas, revestimentos macios e adesivos; e com isocianatos, resultando em poliuretanas.

Tem efeito acidulante e flavorizante, ou seja, é capaz de tornar o sabor de alimentos e bebidas mais ácidos e disfarçar sabores indesejáveis oferecidos por outros componentes. Por isto, é utilizado na produção de refrigerantes de frutas, queijos, marmeladas, pós para alimentos e como indutor da formação de géis que se 
assemelham com gelatinas e geleias. Também é utilizado na fabricação de ésteres aplicados aos lubrificantes e plastificantes, adesivos, espumas de poliuretano, tintas, medicamentos, resinas, fixadores de perfumes, reagentes analíticos e como catalisador em sínteses orgânicas [79].

Esse ácido é biodegradável e, portanto, não se acumula ao longo da cadeia alimentar.

Guerrero e Betancur [73] estudaram o comportamento do ácido adípico como agente de ligação entre Canavalia ensiformis (legume conhecido como feijão de porco) e amido de milho.

Spiridon et al. [81] analisaram o uso de micropartículas de amido modificadas com ácido adípico e glicerol na fabricação de compósitos de amido e lignina, mas neste caso, o ácido adípico foi utilizado como aditivo de enchimento no glicerol.

Silva et al. [63] verificaram o uso de ácido adípico como compatibilizante em filmes da blenda amido/PBAT.

c) Ácido Málico (AM)

Membro do grupo dos ácidos carboxílicos, o ácido málico é um ácido orgânico, de fórmula química $\mathrm{C}_{4} \mathrm{H}_{6} \mathrm{O}_{5}$. Sua estrutura molecular é mostrada na Figura 21. Ele é solúvel em água, de nomenclatura oficial ácido hidroxibutenodióico, diácido. Apresenta aspecto de cristais brancos em sua forma pura, é inodoro e tem sabor fortemente azedo.

Figura 21 - Representação da estrutura química do ácido málico.

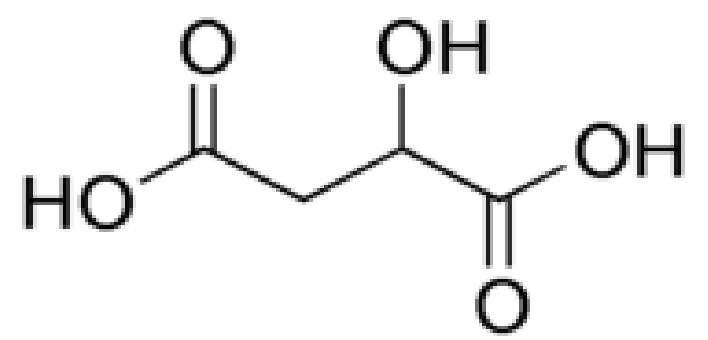

Fonte: [82] 
O ácido málico foi isolado pela primeira vez em 1785, pelo químico sueco Carl Wilhelm Scheele, a partir do suco de maçã, por isso recebeu o nome de ácido málico (do latim malum, que quer dizer maçã). É o ácido mais abundante na maçã. Além da maçã, outros frutos como a pera, a amora silvestre, a framboesa, a uva, o abacaxi e a romã também possuem ácido málico, porém, em menores proporções. É produzido industrialmente pela hidratação do ácido maleico e ácido fumárico.

$\mathrm{Na}$ indústria alimentícia, o ácido málico é um composto importante. Primeiro pela sua propriedade acidulante, ou seja, é capaz de neutralizar o sabor doce de alimentos e bebidas, tornando-o mais ácido. Depois, pela sua ação flavorizante, que tem a função de realçar o sabor dos alimentos e mascarar sabores indesejáveis fornecidos por outros ingredientes (especialmente da sacarina, um tipo de adoçante). A produção de: geleias, pós para sobremesas, sucos artificiais e refrigerantes utiliza o ácido málico como acidulante.

$\mathrm{Na}$ indústria farmacêutica, esse ácido é aplicado ao tratamento de ferimentos, atuando como higienizador e regenerador tecidual; e, combinado com o magnésio participa do tratamento da fibromialgia, agindo como uma espécie de relaxante muscular. O ácido málico é uma das fontes naturais de alfa-hidroácidos, substâncias muito utilizadas pela área estética na famosa técnica do peeling.

No processo de vinificação, o ácido málico participa da fermentação malolática, uma reação química que converte o ácido málico em ácido lático, por meio da ação de bactérias do tipo coccus e lactobacilos. Isso contribui para melhorar a qualidade do vinho, já que o ácido lático produzido é bem mais suave do que o do ácido málico, portanto, conferindo à bebida um sabor e um aroma mais agradáveis.

O ácido málico é incompatível com oxidantes fortes, bases fortes, aminas, carbonatos e metais alcalinos. Embora seja biodegradável, sua decomposição produz substâncias nocivas ao meio ambiente como o anidrido maleico, o ácido maleico e os gases monóxido e dióxido de carbono.

Majzoobi et al. [60] estudaram o efeito do ácido cítrico e do ácido málico em algumas propriedades de filmes de amido e de amido reticulado. Os ácidos causaram: queda na viscosidade intrínseca, aumento na solubilidade em água e queda na absorção de água. Em relação às propriedades mecânicas, ocorreu queda: na dureza, 
na adesividade, na elasticidade, e na coesão dos filmes de amido. Apesar de ambos os ácidos alterarem as propriedades dos filmes de amido, o ácido málico mostrou-se mais eficaz.

d) Ácido Tartárico (AT)

O ácido tartárico é um composto orgânico de nomenclatura oficial ácido 2,3dihidroxibutanodioico, representado pela fórmula química $\mathrm{C}_{4} \mathrm{H}_{6} \mathrm{O}_{6}$, possui em sua estrutura funções do tipo ácido carboxílico e álcool, como pode ser visto na Figura 22. É solúvel em água e encontrado naturalmente no estado sólido (cristais), de cor branca ou transparente, inodoro, de sabor fortemente ácido, estável ao ar e à luz e é biodegradável [83].

Figura 22 - Representação da estrutura química do ácido tartárico.

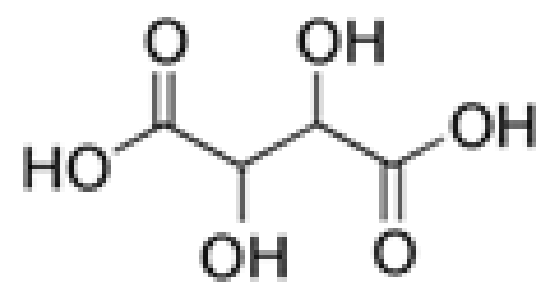

Fonte: [84]

Geralmente obtém-se o ácido tartárico por meio da reação química de anidrido maleico e peróxido de hidrogênio, (o primeiro confere um sabor amargo ao produto) ou pela fermentação de polpas de frutas como uva, tamarindo, amora e abacaxi. Pode ser encontrado no sedimento de vinhos e no mosto fermentado.

Trata-se de um composto muito utilizado pela indústria de alimentos e bebidas devido ao seu efeito acidulante, ou seja, capaz de tornar o sabor mais ácido. O processo de vinificação depende da participação do ácido tartárico, uma vez que, ele modifica minimamente a composição do vinho, diminuindo o nível de acidez volátil e realçando a cor, o que melhora a qualidade da bebida. Também é utilizado na fabricação de sobremesas, sucos artificiais, caramelos e geleias, os quais, geralmente, apresentam sabor de uva. $\mathrm{Na}$ indústria farmacêutica, o ácido tartárico 
combinado com o bicarbonato de sódio é utilizado na fabricação de efervescentes (antiácidos e sais de fruta), e na composição de hidratantes corporais. Aplica-se o ácido tartárico em xampus indicados no tratamento da calvície, pois aumenta a irrigação sanguínea. Ainda pode ser utilizado na produção do cimento e do gesso e como mordente (capacidade de manter a durabilidade da cor de tecidos) na indústria têxtil.

Olivato et al. [85-89] estudaram a influência do ácido cítrico, ácido málico e ácido tartárico como compatibilizantes em filmes de amido/PBAT. Foi verificado que o uso desses ácidos melhora as propriedades da blenda devido à ligação cruzada que conecta as cadeias poliméricas, o que torna o material mais resistente e menos permeável.

\section{e) Outros Ácidos Carboxílicos}

Da Róz et al compararam o efeito do ácido cítrico $(\mathrm{AC})$ e do ácido ascórbico no TPS composto por amido de milho, 30\% em massa de glicerol e 0,5\% em massa de ácido esteárico. Observou-se que a massa molar diminui com o aumento do teor dos ácidos e com o tempo de processamento, causando redução da viscosidade, aderência a superfície de processamento e queda no valor da $T_{m}$.

Este estudo irá analisar o uso de quatro ácidos carboxílicos como plastificantes para o TPS. Espera-se que os ácidos carboxílicos auxiliem na hidrólise do amido, facilitando a desestruturação e ruptura dos grânulos, diminuindo a viscosidade do material e melhorando as propriedades de processamento, o que pode levar a produção de uma matriz mais homogênea. 


\subsection{PARTE EXPERIMENTAL}

\subsubsection{Materiais}

Foram utilizados o amido de milho nativo contendo $28 \%$ de amilose e $11 \%$ de umidade, o Amidex ${ }^{\circledR} 3001$ da Ingredion. Utilizou-se também água destilada, glicerol (massa molecular $=92,09 \mathrm{u}$ ), e os ácidos carboxílicos:

- adípico puro (massa molecular = 146,14 u),

- cítrico anidro (massa molecular = 192,13 u),

- málico DL (massa molecular =134,09 u) e

- tartárico anidro P.A (massa molecular =150,09 u).

Todos os ácidos foram obtidos na Casa Americana de artigos para Laboratórios.

\subsubsection{Procedimento Experimental}

O procedimento experimental foi dividido em três partes:

- Na Etapa I foi realizado um planejamento estatístico para verificar qual a composição ótima para o amido termoplástico (TPS), preparado a partir de amido de milho, água, glicerol e ácido cítrico;

- Na Etapa 2: Para complementar a etapa de otimização da composição e das condições de processamento do TPS, foram preparadas mais algumas amostras de TPS, variando-se os teores de água e de ácido cítrico e a temperatura de processamento;

- Na Etapa III: utilizando o que foi considerada a composição ótima para o TPS, estudou-se a substituição do ácido cítrico por outros três ácidos carboxílicos: adípico, málico e tartárico, para verificar a influência dos mesmos nas propriedades do TPS. 


\subsubsection{Etapa I: Otimizando a composição e a condição de processamento do TPS com ácido cítrico}

Para esta etapa escolheu-se trabalhar apenas com o ácido cítrico, para uma melhora comparação com alguns estudos já realizados. Para o estudo proposto neste trabalho foram escolhidos cinco parâmetros de entrada: 2 de composição (umidade e teor de ácido cítrico) e 3 de processamento (temperatura, velocidade dos rotores e tempo). Pela literatura $[22,23,61,71,90]$ estabeleceram-se os intervalos de variações dos parâmetros. Também se observou que os parâmetros mais relevantes a serem analisados eram a umidade, o teor de ácido e a temperatura de processamento. Para essas três variáveis de entrada foram utilizados 3 níveis de intensidade, e, para os demais, velocidade dos rotores e tempo, 2 níveis.

Neste trabalho foi utilizado um planejamento fatorial $2^{2} \times 3^{3-1}$, onde as variáveis de entrada são:

- $2^{2}$ - tempo de processamento (8 e $15 \mathrm{~min}$ ) e velocidade dos rotores (100 e 150rpm) durante o processamento do TPS num misturador interno ou câmara de mistura;

- $3^{\mathrm{n}-1}$ (com $\left.\mathrm{n}=3\right)$ - temperatura de processamento $\left(100,125\right.$ e $\left.150^{\circ} \mathrm{C}\right), \%$ de umidade $(10,20,30 \%)$ e \% de ácido $(0,4$ e 10\%) na mistura.

No planejamento $2^{2}$ existem dois níveis -1 (mínimo) e +1 (máximo), como mostra a Tabela 1. Assim, para a variável tempo, -1 equivale a 8 minutos $e+1$ equivale a 15 minutos. E para a variável velocidade dos rotores, -1 equivale a $100 \mathrm{rpm} \mathrm{e}+1$ equivale a $150 \mathrm{rpm}$.

Tabela 1 - Tabela de Planejamento $2^{2}$ com as variáveis de entrada.

\begin{tabular}{|c|c|}
\hline Tempo & Velocidade dos rotores \\
\hline-1 & -1 \\
\hline-1 & +1 \\
\hline $\mathbf{1}$ & +1 \\
\hline $\mathbf{+ 1}$ & -1 \\
\hline
\end{tabular}

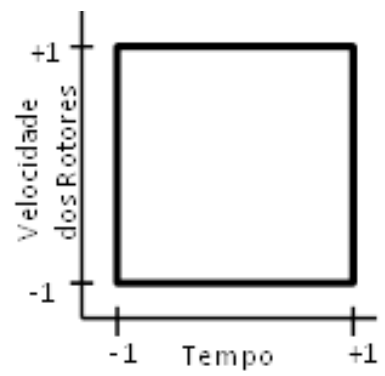


Levando em consideração apenas o fatorial com 3 níveis, sua representação é feita com: 0 para o menor nível, 1 para o nível intermediário e 2 para o maior nível. Se fosse realizada a análise com $3^{3}$ seriam 27 combinações possíveis apenas com os parâmetros: temperatura de processamento, teor de umidade e teor de ácido. Com o objetivo de diminuir o número de combinações, e consequentemente de amostras, foi realizado o planejamento $3^{3-1}$, o qual determina apenas 9 combinações das 27 possíveis, como mostra a Figura 23.

Figura 23 - Escolha dos parâmetros para o planejamento $3^{3-1}$ fatorial.

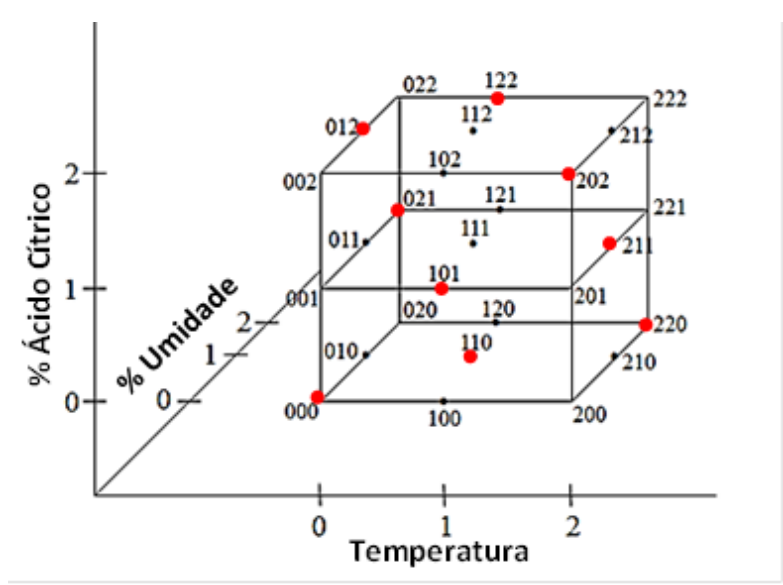

Dessa forma tem-se o planejamento, com 36 combinações no total, como mostra a Tabela 2.

Verifica-se que a mesma mistura foi utilizada em 4 diferentes processamentos:

- 8 min e 100 rpm;

- 8 min e 150 rpm;

- 15 min e 100 rpm;

- 15 min e 150 rpm.

Foram fixados os parâmetros de $2^{2}$ fatorial, fazendo uma análise para cada par de tempo de processamento e velocidade dos rotores. Além disso, as intensidades dos parâmetros de $3^{3-1}$ foram normalizadas para facilitar a análise da influência de cada fator. As equações de conversão para dados normalizados estão representadas na Tabela 3 , onde $\mathbf{T}$ é a temperatura $\mathrm{em}^{\circ} \mathrm{C}$, u é o percentual de água (umidade) e a 
o percentual de ácido. Na Tabela 4 pode-se observar os parâmetros normalizados para as diferentes misturas

Tabela 2- Composição e parâmetros de processamento das amostras.

Amostra Temperatura $\left({ }^{\circ} \mathrm{C}\right) \quad$ Umidade (\%) Ácido (\%) Tempo (min) vel. dos rot. (rpm)

\begin{tabular}{|c|c|c|c|c|c|}
\hline 1 & 100 & 10 & 0 & 8 & 100 \\
\hline 2 & 125 & 10 & 4 & 8 & 100 \\
\hline 3 & 150 & 10 & 10 & 8 & 100 \\
\hline 4 & 100 & 20 & 10 & 8 & 100 \\
\hline 5 & 125 & 20 & 0 & 8 & 100 \\
\hline 6 & 150 & 20 & 4 & 8 & 100 \\
\hline 7 & 100 & 30 & 4 & 8 & 100 \\
\hline 8 & 125 & 30 & 10 & 8 & 100 \\
\hline 9 & 150 & 30 & 0 & 8 & 100 \\
\hline 10 & 100 & 10 & 0 & 8 & 150 \\
\hline 11 & 125 & 10 & 4 & 8 & 150 \\
\hline 12 & 150 & 10 & 10 & 8 & 150 \\
\hline 13 & 100 & 20 & 10 & 8 & 150 \\
\hline 14 & 125 & 20 & 0 & 8 & 150 \\
\hline 15 & 150 & 20 & 4 & 8 & 150 \\
\hline 16 & 100 & 30 & 4 & 8 & 150 \\
\hline 17 & 125 & 30 & 10 & 8 & 150 \\
\hline 18 & 150 & 30 & 0 & 8 & 150 \\
\hline $\begin{array}{l}19 \\
20\end{array}$ & $\begin{array}{l}100 \\
125\end{array}$ & $\begin{array}{l}10 \\
10\end{array}$ & $\begin{array}{l}0 \\
4\end{array}$ & $\begin{array}{l}15 \\
15\end{array}$ & $\begin{array}{l}100 \\
100\end{array}$ \\
\hline 21 & 150 & 10 & 10 & 15 & 100 \\
\hline 22 & 100 & 20 & 10 & 15 & 100 \\
\hline 23 & 125 & 20 & 0 & 15 & 100 \\
\hline 24 & 150 & 20 & 4 & 15 & 100 \\
\hline 25 & 100 & 30 & 4 & 15 & 100 \\
\hline 26 & 125 & 30 & 10 & 15 & 100 \\
\hline 27 & 150 & 30 & 0 & 15 & 100 \\
\hline $\begin{array}{l}28 \\
29\end{array}$ & $\begin{array}{l}100 \\
125\end{array}$ & $\begin{array}{l}10 \\
10\end{array}$ & $\begin{array}{l}0 \\
4\end{array}$ & $\begin{array}{l}15 \\
15\end{array}$ & $\begin{array}{l}150 \\
150\end{array}$ \\
\hline 30 & 150 & 10 & 10 & 15 & 150 \\
\hline 31 & 100 & 20 & 10 & 15 & 150 \\
\hline 32 & 125 & 20 & 0 & 15 & 150 \\
\hline 33 & 150 & 20 & 4 & 15 & 150 \\
\hline 34 & 100 & 30 & 4 & 15 & 150 \\
\hline 35 & 125 & 30 & 10 & 15 & 150 \\
\hline 36 & 150 & 30 & 0 & 15 & 150 \\
\hline
\end{tabular}


Tabela 3 - Equações de conversão para temperatura, teor de ácido e umidade, para valores normalizados, onde $\mathrm{T}$ é a temperatura $\mathrm{em}{ }^{\circ} \mathrm{C}$, u é o percentual de água (umidade) e a $\mathrm{o}$ percentual de ácido.

$$
\mathrm{T}\left({ }^{\circ} \mathrm{C}\right)=25 \mathrm{~T}^{\star}+125 \quad \mathrm{u}(\%)=10 \mathrm{u}^{\star}+20 \quad \mathrm{a}(\%)=\mathrm{a}^{\star 2}+5 \mathrm{a}^{\star}+4
$$

Tabela 4 - Parâmetros normalizados para as diferentes misturas, onde T é a temperatura em ${ }^{\circ} \mathrm{C}$, u é o percentual de água (umidade) e a o percentual de ácido.

\begin{tabular}{cccc} 
Mistura & $\mathbf{T}^{\boldsymbol{*}}$ & $\mathbf{u}^{\mathbf{*}}$ & $\mathbf{a}^{\mathbf{*}}$ \\
\hline $\mathbf{1}$ & -1 & -1 & -1 \\
$\mathbf{2}$ & 0 & -1 & 0 \\
$\mathbf{3}$ & 1 & -1 & 1 \\
$\mathbf{4}$ & -1 & 0 & 1 \\
$\mathbf{5}$ & 0 & 0 & -1 \\
$\mathbf{6}$ & 1 & 0 & 0 \\
$\mathbf{7}$ & -1 & 1 & 0 \\
$\mathbf{8}$ & 0 & 1 & 1 \\
$\mathbf{9}$ & 1 & 1 & -1 \\
\hline
\end{tabular}

\subsection{Preparação do TPS}

Primeiramente o amido foi seco em estuda a vácuo por 48 horas, a 110ํ․ Para verificar se o amido, após a etapa de secagem, estava realmente seco, foi realizada análise de termogravimetria (TG). A Figura 24 apresenta o resultado de TG do amido seco, confirmando que o mesmo não apresenta perda de massa, referente à perda de água, até cerca de $250^{\circ} \mathrm{C}$.

Na preparação do TPS utilizou-se, além do amido de milho, o glicerol e os ácidos carboxílicos. Os teores de água e ácidos foram calculados a partir da massa de amido. Essas misturas já pesadas foram misturadas com auxílio de um misturador IKA ${ }^{\circledR}$ Werke Eurostar (Figura 25), a 1500rpm, por 20 minutos, para garantir a homogeneidade da mistura. 
Figura 24 - Curva de termogravimetria do amido seco por $48 \mathrm{~h}$ a $110^{\circ} \mathrm{C}$.

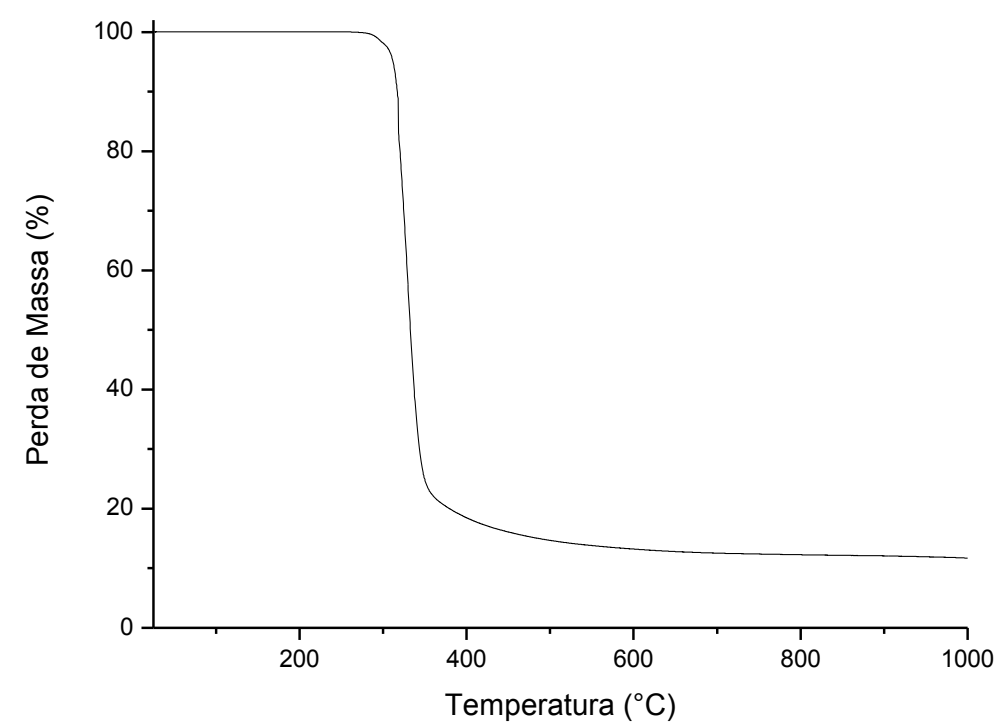

Figura 25 - Mistura mecânica das amostras de TPS.

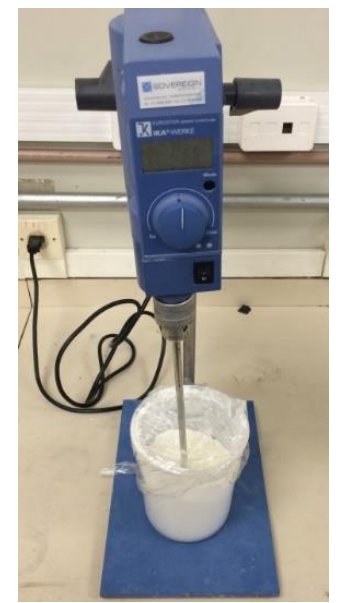

As misturas foram, então, seladas e armazenadas (Figura 26) em estufa a 25드, por no mínimo 24h. As misturas foram depois processadas em um mixer acoplado a um reômetro de torque Thermo Haake Polylab900 System.

Na Etapa I foram preparadas 9 misturas, utilizando como ácido carboxílico apenas o ácido cítrico, como mostra a Tabela 5. 
Com cada mistura foram realizados 4 ensaios, variando 0 tempo de processamento e rotação dos rotores: 8 min e 100rpm; 8 min e 150 rpm; 15 min e 100 rpm e; 15 min 150 rpm.

Figura 26 - Mistura selada, pronta para ser colocada na estufa.

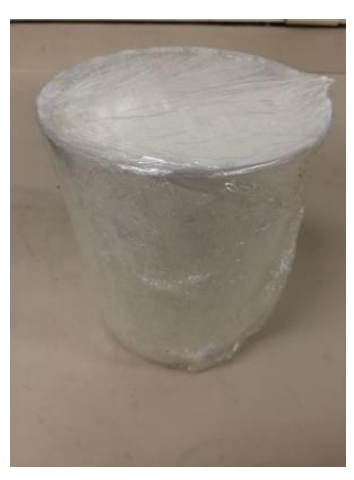

Tabela 5- Composição das misturas $\left(m_{x}=\right.$ massa do componente $\left.x\right)$.

\begin{tabular}{c|cccc}
\hline Mistura & mamido $(\mathrm{g})$ & mágua $(\mathrm{g})$ & mglicerol $(\mathrm{g})$ & mácido $(\mathrm{g})$ \\
\hline 1 & 196 & 19,6 & 84 & 0 \\
2 & 196 & 19,6 & 84 & 11,2 \\
3 & 196 & 19,6 & 84 & 28 \\
4 & 196 & 39,2 & 84 & 28 \\
5 & 196 & 39,2 & 84 & 0 \\
6 & 196 & 39,2 & 84 & 11,2 \\
7 & 196 & 58,8 & 84 & 11,2 \\
8 & 196 & 58,8 & 84 & 28 \\
9 & 196 & 58,8 & 84 & 0 \\
\hline
\end{tabular}

A análise dos dados obtidos a partir das misturas descritas na Tabela 5 foi utilizada para otimizar a composição e a condição de processamento do TPS. Na Etapa II foi realizado um estudo mais aprofundado sobre a composição e o processamento do TPS, com apenas 4 misturas. Foram selecionadas como variáveis os teores de água e de ácido cítrico, e a temperatura de processamento.

Finalmente, utilizando a composição selecionada na Etapa II, foram preparados TPS com outros ácidos carboxílicos, além do ácido cítrico. Foram utilizados os ácidos: adípico, málico e tartárico. 
3.3.2.2 Etapa II: Otimizando a composição e a condição de processamento do TPS com ácido cítrico

Nesta etapa foram preparadas três novas composições (7mod, AC2 e AC3). Foram modificados os teores de água e de ácido cítrico e a temperatura de processamento. Desta forma pode-se observar a influência de cada parâmetro. Como será visto em 3.4 .2

\subsubsection{Etapa III: Otimizando a composição e a condição de processamento do TPS com ácido cítrico}

Utilizando o que foi considerada a composição ótima para o TPS, estudou-se a substituição do ácido cítrico por outros três ácidos carboxílicos: adípico, málico e tartárico, para verificar a influência dos mesmos nas propriedades do TPS. Como será explicado em 3.4.3.

\subsubsection{CARACTERIZAÇÃO}

\subsubsection{Curvas de Torque}

Para verificar o comportamento do torque durante o processamento, e assim, analisar os picos de gelatinização das amostras, foram realizadas análises das curvas de torque geradas durante o processamento no Reômetro de torque Haake.

\subsubsection{Espectroscopia Vibracional de Absorção no infravermelho com transformada de Fourier (FTIR)}

Foram feitas análises químicas por espectroscopia no infravermelho. As amostras foram transformadas em pó, por criofratura, utilizando nitrogênio líquido.

$\mathrm{Na}$ Etapa I, as amostras foram prensadas em pastilhas com um substrato de $90 \%$ de $\mathrm{KBr}$. As amostras foram analisadas por absorbância e a altura dos picos foi padronizada em relação ao pico de $1030 \mathrm{~cm}^{-1}$ (correspondente à ligação C-O-C do 
anel anidroglucose). Essa ligação não difere entre as amostras, pois dificilmente os anéis anidroglucose serão quebrados durante o processamento.

Nas Etapas II e III a espectroscopia no infravermelho foi realizada por reflexão difusa (Drift).

As amostras foram analisadas no equipamento Nicolet, modelo 6700 , com resolução de $4 \mathrm{~cm}^{-1}$, localizado no Laboratório de Processos Cerâmicos do Departamento de Engenharia Metalúrgica e de Materiais da Escola Politécnica da Universidade de São Paulo (EPUSP).

\subsubsection{Análise Termogravimétrica}

As análises termogravimétricas $(\mathrm{TG})$ foram realizadas da temperatura ambiente até $1000^{\circ} \mathrm{C}$, a $20^{\circ} \mathrm{C} / \mathrm{min}$, em atmosfera de $\mathrm{N}_{2}$ com fluxo de $20 \mathrm{ml} / \mathrm{min}$. Para isso foram pesadas aproximadamente $10 \mathrm{mg}$ de amostra e colocadas em cadinho de alumina. Em seguida, as amostras foram colocadas no equipamento STA 449 F1 da Netzsch, localizado no Laboratório de Análises Térmicas do Departamento de Engenharia Metalúrgica e de Materiais da EPUSP, e obteve-se as curvas de TG e DTG (derivada da curva de termogravimetria).

\subsubsection{Calorimetria Exploratória Diferencial (DSC)}

Para analisar as temperaturas de transição vítrea $\left(T_{g}\right)$, a temperatura de fusão $\left(T_{m}\right)$ e a sub-Tg foram realizadas análises das curvas de DSC. As amostras primeiramente foram resfriadas até $-150^{\circ} \mathrm{C}$ a $10^{\circ} \mathrm{C} / \mathrm{min}$, e em seguida foram aquecidos até $230^{\circ} \mathrm{C}$, mantendo a mesma taxa. Os ensaios foram realizados num equipamento DSC 200 F3 Maia da Netzsch localizado no Laboratório de Análises Térmicas do PMTEPUSP.

\subsubsection{Difração de Raios X (DRX)}

Nas Etapas II e III 75mg de amostras de TPS moídas com auxílio de nitrogênio foram misturadas com $18,75 \mathrm{mg}$ de óxido de alumínio $\left(\mathrm{Al}_{2} \mathrm{O}_{3}\right)$, para ajustar a posição dos picos de difração, de acordo com a ficha 000461212. As curvas de DRX foram 
obtidas num difratômetro da marca Bruker, modelo D8 Advance Da Vinci, localizado no Departamento de Geologia da Universidade de São Paulo. Utilizou-se o cobre como fonte geradora de raios-x (comprimento de onda 1,5418 $\AA$ ). A varredura foi realizada na faixa de $2 \theta=2^{\circ}$ até $2 \theta=60^{\circ}$, com tempo de varredura de $0,2 \mathrm{~s}$, abertura do detector de $2,942^{\circ}, 40 \mathrm{kV}$ e $40 \mu \mathrm{A}$.

\subsubsection{Microscopia Eletrônica de Varredura (MEV)}

As análises de MEV foram efetuadas em dois microscópios: Microscópio Eletrônico de Varredura, Philips XL 30 e Microscópio Eletrônico de Varredura modelo FEG Inspect F50, marca FEI Philips. Ambos estão localizados no Departamento de Engenharia Metalúrgica e de Materiais da EPUSP. As amostras foram criofraturadas, e recobertas com ouro (sputtering), antes da sua observação no microscópio.

\subsubsection{Propriedades Mecânicas: Ensaio de Tração}

A partir do resultado da Etapa I foi escolhida a melhor composição. Então, nas Etapas II e III, as amostras obtidas foram calandradas em uma calandra Mecanoplast, localizada no laboratório de Polímeros da Universidade Presbiteriana Mackenzie, por 25 minutos, para formar um filme de $3 \mathrm{~mm}$ de espessura. Pode-se notar a diferença entre as amostras antes (Figura 27 a) e depois (amostra em forma de filme, Figura 27 b) de serem colocadas na calandra.

Após obter o filme na calandra, corpos de prova de tração foram obtidos com o auxílio de facas de corte para estampagem (Figura 27 c).

Os ensaios de tração foram realizados em duas direções: na direção vertical de calandragem (y) e na direção horizontal $(x)$ de calandragem, como mostra a Figura 28. Foram realizados 8 ensaios para cada direção.

Os ensaios de tração foram realizados em uma Máquina Universal de Ensaios Instron 3369, localizada no Laboratório de Ensaios Poliméricos da Universidade Federal do ABC. A máquina possui célula de carga de $50 \mathrm{kN}$. O ensaio foi realizado com velocidade do travessão de 50 mm/min, conforme a norma ASTM D638-10 [91]. 
Figura 27- Processo de calandragem e moldagem por compressão amostra após ser retirada da câmara de mistura (a), amostra após o processo de calandragem(b) e corpo de prova após ser moldado por compressão.

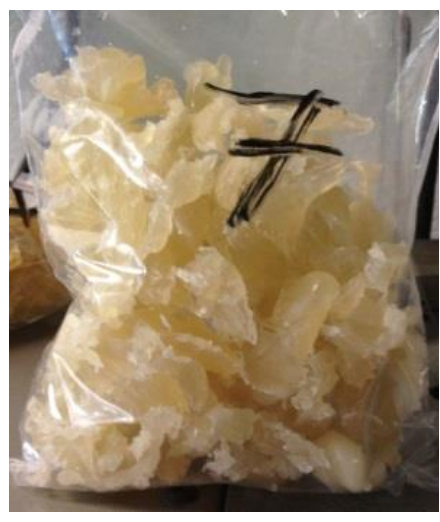

(a)

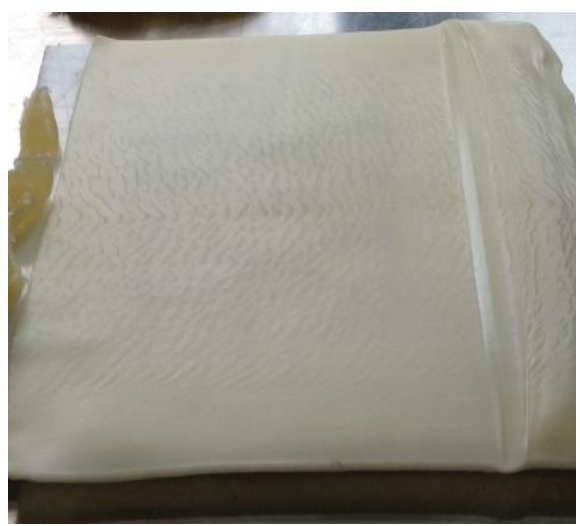

(b)

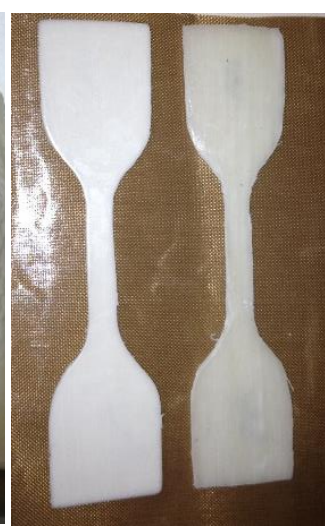

(c)

Figura 28 - Direção das amostras quando processadas na calandra utilizdas nos ensaios de tração.

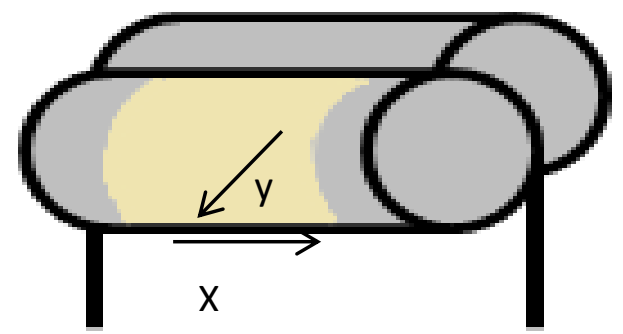

\subsubsection{Grau de Substituição (GS) e Grau de Esterificação (GE)}

Antes do teste, os plastificantes que não tinham reagido durante a etapa de preparo das amostras, tais como os ácidos carboxílicos de glicerol e residuais, foram removidos com água, de modo que o efeito dos plastificantes no grau de substituição (GS) e grau de Esterificação (GE) pode ser negligenciado.

O grau de substituição molar (GS) é o número de unidades de ácido cítrico por unidade de anidroglucose amido. O GS foi determinado utilizando o método de Xing et al. [27, 35, 36, 37], com pequena modificação, como descrito abaixo. 
Aproximadamente $1,0 \mathrm{~g}$ de TPS seco foi pesado e colocado em um erlenmeyer de $250 \mathrm{ml}$. Em seguida, $50 \mathrm{~mL}$ de uma solução de etanol $75 \%$ foi adicionada ao erlenmeyer, sendo agitada e aquecida a $50^{\circ} \mathrm{C}$ durante 60 minutos e, em seguida, arrefecida até a temperatura ambiente. Então, adicionou-se $20 \mathrm{~mL}$ de uma solução padrão 0,5 M de hidróxido de sódio $(\mathrm{NaOH})$; o erlenmeyer foi fechado e agitado, com um agitador magnético, durante $48 \mathrm{~h}$. O excesso de álcali foi titulado com uma solução padrão $0,2 \mathrm{M}$ de ácido clorídrico $(\mathrm{HCl})$ aquoso. Como indicadores foram utilizados Fenolftaleína e pHmetro. Cada amostra foi medida em triplicata.

O grau de esterificação foi calculado de acordo com a Equação 5.

$$
G E=\left(V_{\mathrm{NaOH}} x N_{\mathrm{NaOH}}-V_{\mathrm{HCl}} x N_{\mathrm{HCl}}\right) \times M \times 100 / \mathrm{m}
$$

Onde: $\mathrm{V}_{\mathrm{NaOH}}$ e $\mathrm{V}_{\mathrm{HCL}}$ são os volumes (L) das soluções de $\mathrm{NaOH}$ e $\mathrm{HCl}$, e $\mathrm{N}_{\mathrm{NaOH}}$ e NHCI são as concentrações molares (mol/L) dos mesmos. M é a adição do peso de uma unidade do anel de glucose, que foi substituído pelo ácido cítrico, este valor é de $174(\mathrm{~g} / \mathrm{mol})$. E m (g) é a massa da amostra.

O grau de substituição foi calculado de acordo com a Equação 6 .

$$
G S=162 x A /(1-M x A)
$$

Onde A é a molaridade da solução de $\mathrm{NaOH}$ que reagiu com $1 \mathrm{~g}$ de substituição e 162 é a massa molecular da unidade de anel de glucose.

\subsection{RESULTADOS E DISCUSSÕES}

\subsubsection{Etapa I: Escolha da composição do TPS, utilizando ácido cítrico}

A otimização da composição do TPS, segundo o critério de avaliação empregado neste trabalho, foi realizada uma análise para cada resposta (torque, altura do pico obtido por FTIR e temperatura de degradação). 
Para os parâmetros com tratamento $3^{3-1}$ fatorial, usou-se um modelo quadrático que, diferentemente do modelo linear, permite ter máximos e mínimos no interior dos intervalos e não somente nas extremidades. A regressão quadrática pode ser escrita como mostra a Equação 7:

$$
y=\beta_{0}+\beta_{1} x_{1}+\beta_{2} x_{2}+\beta_{3} x_{3}+\beta_{12} x_{1} x_{2}+\beta_{13} x_{1} x_{3}+\beta_{23} x_{2} x_{3}+\beta_{11} x_{1}^{2}+\beta_{22} x_{2}^{2}+\beta_{33} x_{3}^{2}+\varepsilon
$$

Onde y é o dado estudado, $x_{1}$, x2 e x3 são as variáveis da mistura: umidade, quantidade de ácido cítrico e temperatura e $\beta$ são os coeficientes obtidos pela otimização das superfícies de resposta.

Primeiramente foi feita uma correlação linear entre os termos da regressão quadrática e as respostas. Dessa correlação obtida foram retirados os termos com correlação em módulo menor do que 0,1 .

Posteriormente, foi feita a regressão somente com os termos que sobraram. Como critério de avaliação do modelo, foi analisado o $\mathrm{R}^{2}$ e o erro quadrático médio.

A análise dos parâmetros com tratamento $2^{2}$ fatorial foi feita de forma qualitativa. Pois, como há poucos pontos para análise, os modelos matemáticos podem ser imprecisos. Porém, como se trata de um tratamento mais completo, é possível se analisar a influência de cada um dos 2 parâmetros, isoladamente.

\subsubsection{Análise das curvas de torque geradas durante o Processamento}

Durante o processamento das misturas foi registrado o valor de torque em função do tempo de mistura. A área sob as curvas de torque pode ser relacionada à energia absorvida pelo material durante o processamento [95], dessa forma o torque medido está relacionado à viscosidade do material durante o processamento, ou seja, corresponde à resistência do material ao fluxo.

As curvas para as diferentes amostras possuem comportamentos distintos. A Figura 29 mostra exemplos destes comportamentos. Para as amostras com 0\% de ácido cítrico (Figura 29 a), o torque após 4 minutos tende a aumentar, isso ocorre para todas as misturas sem ácido (Misturas 1, 5 e 9). Isso pode indicar perda de água. 
Figura 29-Curvas de torque obtidas durante o processamento das misturas em câmara fechada acoplada ao reômetro de torque (a) sem ácido cítrico e (b) com ácido cítrico.

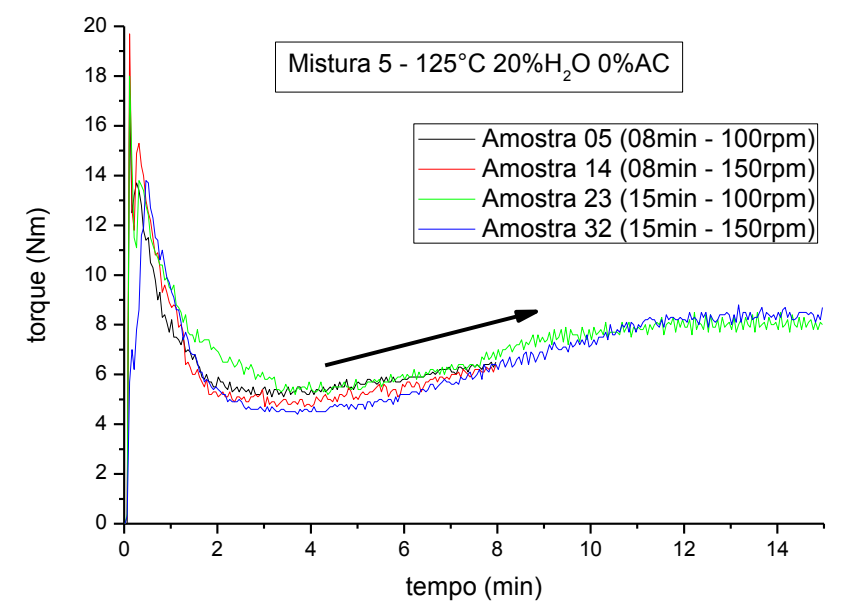

(a)

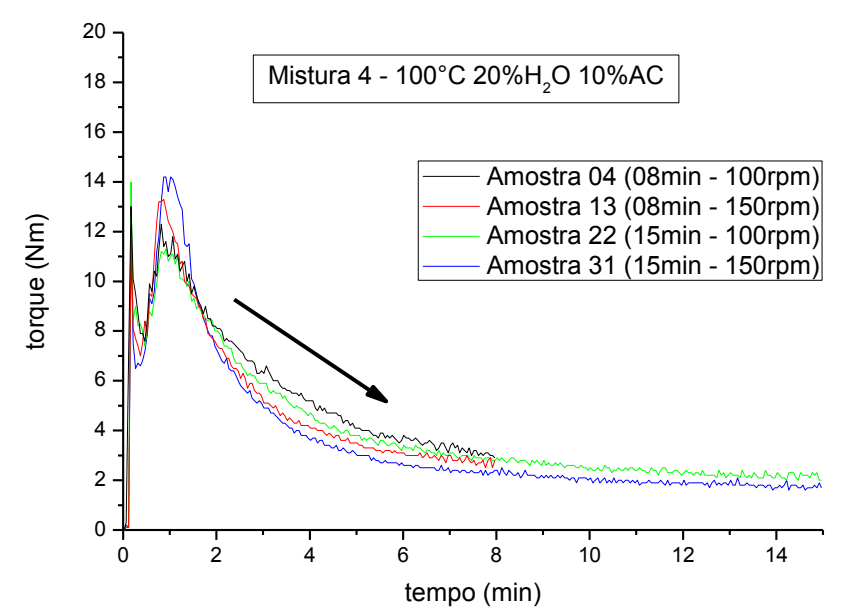

(b)

Já para as amostras com ácido cítrico (Figura 29 b) a tendência é ocorrer queda nos valores de torque. Isso pode ocorrer pois ao adicionar um plastificante ao polímero, as moléculas do plastificante começam a penetrar na fase polimérica, se difundindo entre as macromoléculas poliméricas, aumentando a mobilidade entre as cadeias. O mesmo deve ocorrer ao aumentar o percentual de umidade, pois a presença de água facilita o movimento molecular. Outro fator que também colabora para a redução do torque é a cisão das cadeias poliméricas, provocada pela reação de hidrólise com o ácido cítrico. Essa cisão reduz a massa molar do amido, logo 
diminui sua viscosidade (ver curva de torque em função do tempo, apresentada na Figura 29), o que foi verificado através da análise de FTIR, através da queda no valor do pico.

Ainda que as misturas sem ácido cítrico possuam o pico de gelatinização, a janela de tempo para o processamento é pequena, pois o torque começa a subir, o que pode indicar perda de água. Este aumento no valor do torque acontece a partir de 5 minutos de processamento.

O comportamento da curva de torque em função do tempo das misturas 2 $\left(10 \% \mathrm{H}_{2} \mathrm{O}\right.$ e $\left.4 \% A C\right), 3\left(10 \% \mathrm{H}_{2} \mathrm{O}\right.$ e $\left.10 \% A C\right), 4\left(20 \% \mathrm{H}_{2} \mathrm{O}\right.$ e $\left.10 \% A C\right), 6\left(20 \% \mathrm{H}_{2} \mathrm{O}\right.$ e $4 \% A C), 7\left(30 \% \mathrm{H}_{2} \mathrm{O}\right.$ e $\left.4 \% \mathrm{AC}\right)$ e $8\left(30 \% \mathrm{H}_{2} \mathrm{O}\right.$ e $\left.10 \% \mathrm{AC}\right)$ é característico da plastificação de um polímero pseudoplástico, como pode ser verificado na Figura 30. Vale lembrar que de acordo com o planejamento estatístico cada mistura possui 4 processamentos distintos, devido a variação do tempo de processamento e rotação dos rotores.

Segundo Bousmina [33], na curva de torque do amido, tem-se pelo menos dois picos. O primeiro pico representa o carregamento da amostra, ou seja, quando se coloca a amostra na câmara, que corresponde ao aumento da resistência à livre rotação dos rotores devido à introdução do material. Quando esta resistência é superada, o torque necessário para que os rotores possam girar diminui e atinge rapidamente um estado estacionário. No segundo pico o torque aumenta rapidamente devido ao processo de desestruturação dos grânulos de amido, podendo ocorrer a fusão (ou amolecimento) do material, e em seguida atinge-se um novo estado estacionário. Neste final da curva pode ocorrer: queda do torque, indicando a degradação por cisão das cadeias poliméricas, ou aumento do torque, indicando reticulação do material. Na prática a diferença de tempo entre o primeiro e o segundo estágio é pequena e raramente observada.

O pico de gelatinização em algumas amostras são mais visíveis e intensos do que em outras. No entanto, o torque final se estabiliza com aproximadamente 5 minutos, tornando desnecessário o uso de maiores tempos de processamento. 
Figura 30 - Curvas de torque obtidas até 4 minutos de processamento, das misturas 2, 3, 4, 6, 7 e 8 em câmara fechada acoplada ao reômetro de torque.
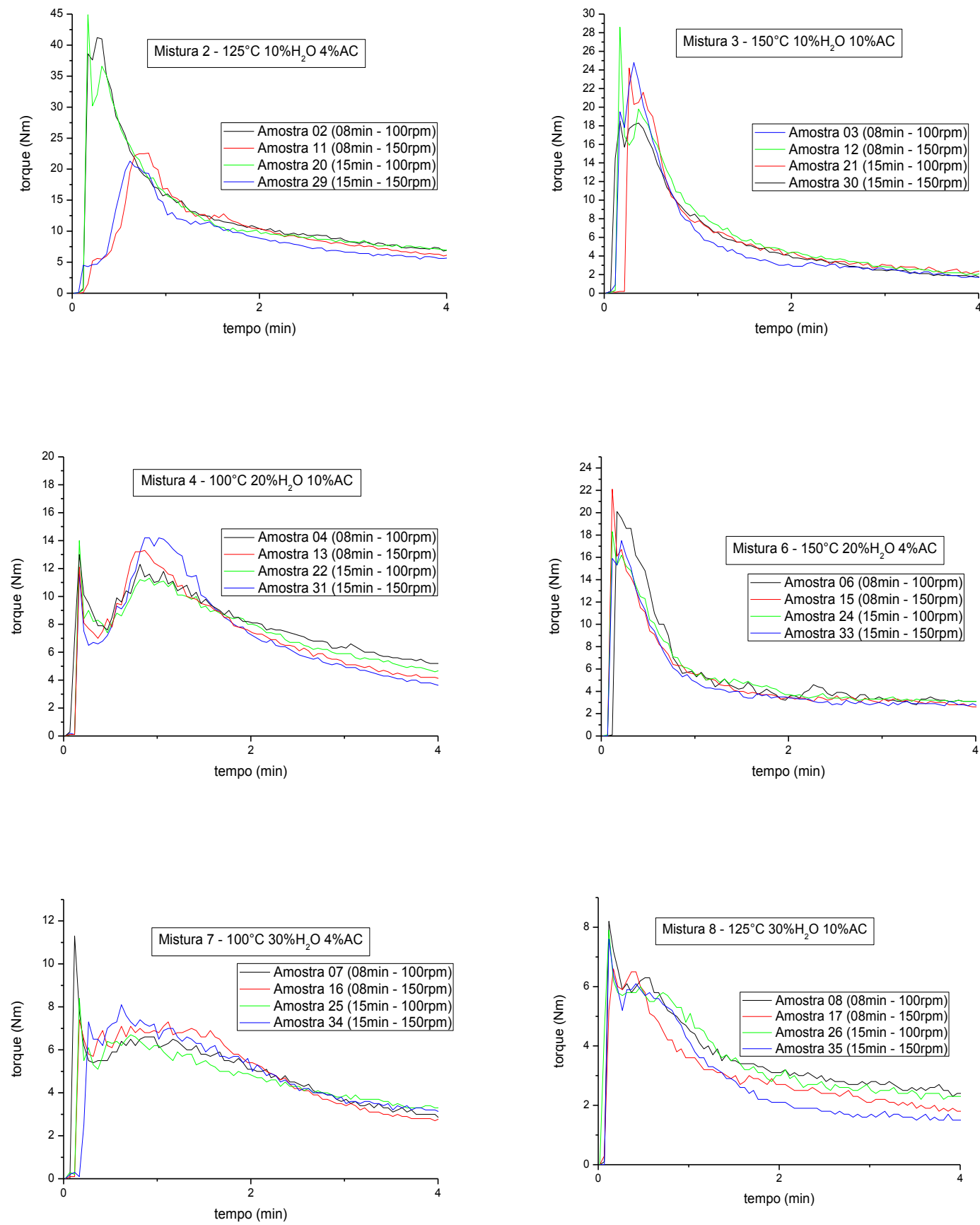

Com os valores de torque obtidos após 4 minutos de processamento, tempo em que o torque começa a ficar estável, foram escolhidas as amostras submetidas a 
8 minutos de mistura, a 100rpm. Com estas foi realizado um tratamento dos dados por regressão, utilizando a ferramenta Solver do MS Excel. Foi obtido o modelo da Equação 8:

$$
\begin{gathered}
\begin{array}{llllll}
( \pm 0,05) & ( \pm 0,03) \quad( \pm 0,03) \quad( \pm 0,03) \quad( \pm 0,03) \quad( \pm 0,04) \quad( \pm 0,06) \quad( \pm 0,05) \quad( \pm 0,05)
\end{array} \\
\tau_{\text {final }}=1,55-1,52 T^{*}-1,52 u^{*}-4,31 a^{*}+3,64 a^{* 2}-1,15 T^{*} u^{*}-0,41 T^{*} a^{*}+1,02 u^{*} a^{*}
\end{gathered}
$$

Onde: $\mathrm{T}$ = temperatura, $\mathrm{u}=$ umidade e $\mathrm{a}=$ ácido cítrico

Fixando a temperatura em $150^{\circ} \mathrm{C}$, obteve-se o gráfico da Figura 31 . Nesse gráfico pode-se observar mais claramente a influência da variação da quantidade de ácido e umidade nos valores de torque (obtido no final do ensaio, para tempo de processamento de 8 minutos). Também se pode observar que com o aumento da quantidade de ácido e de água ocorre uma maior cisão nas cadeias, devido ao efeito plastificante da água, levando à queda da viscosidade. Ao aumentar muito o teor de água, junto com os demais plastificantes, o torque tende a zerar, pois a amostra tornase muito fluida.

Figura 31- Gráfico do torque final em função das composições de ácido e umidade normalizadas, processadas à temperatura de $150^{\circ} \mathrm{C}$, por 8 minutos e a $100 \mathrm{rpm}$.

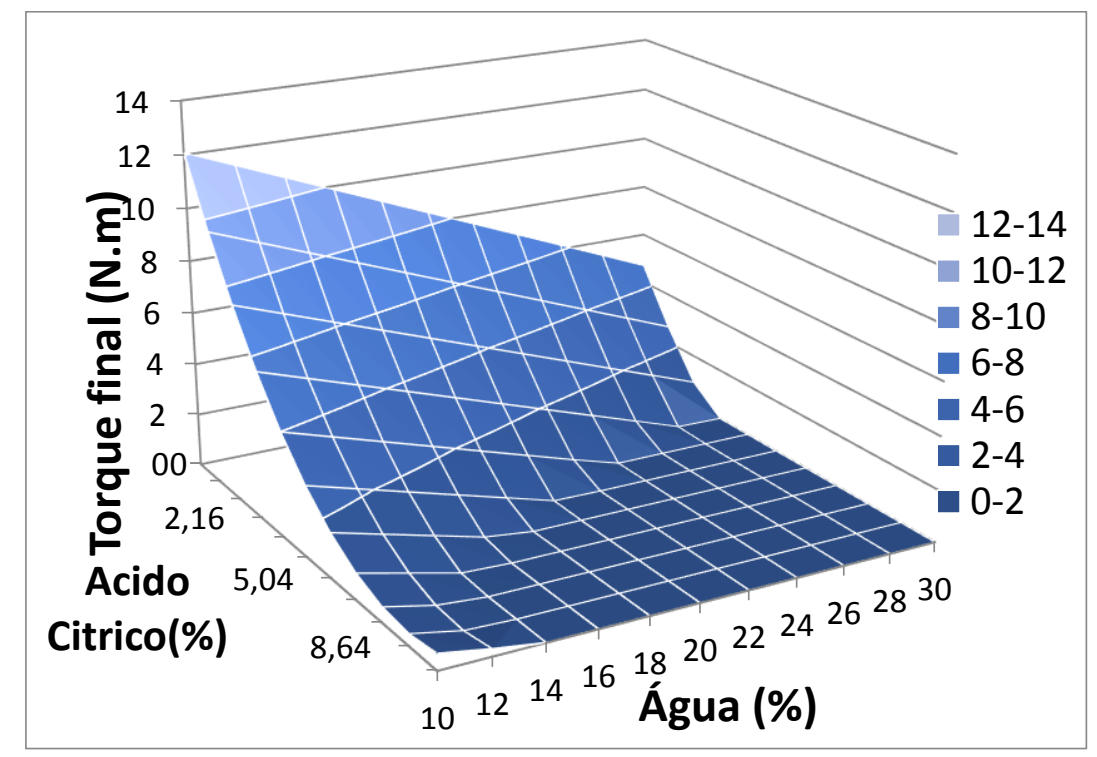




\subsubsection{Espectroscopia Vibracional de Absorção no infravermelho com transformada de Fourier (FTIR)}

A Figura 32 mostra os espectros de infravermelho para o amido e para o ácido cítrico, e, a Figura 33 para as amostras de TPS estudadas.

A análise do espectro do amido puro revela os intervalos $1030-1100 \mathrm{~cm}^{-1} \mathrm{e}$ 3200-3600 cm-1 referentes ao grupo álcool, o pico em 1160 referente ao grupo éter, relativa a ligação $\alpha-1,4$ da amilose, e o pico em $1380 \mathrm{~cm}^{-1}$ é referente ao grupo éster presente na ligação $\alpha-1,6$ da amilopectina.

Figura 32 - Espectros FTIR das amostras de amido e ácido cítrico.

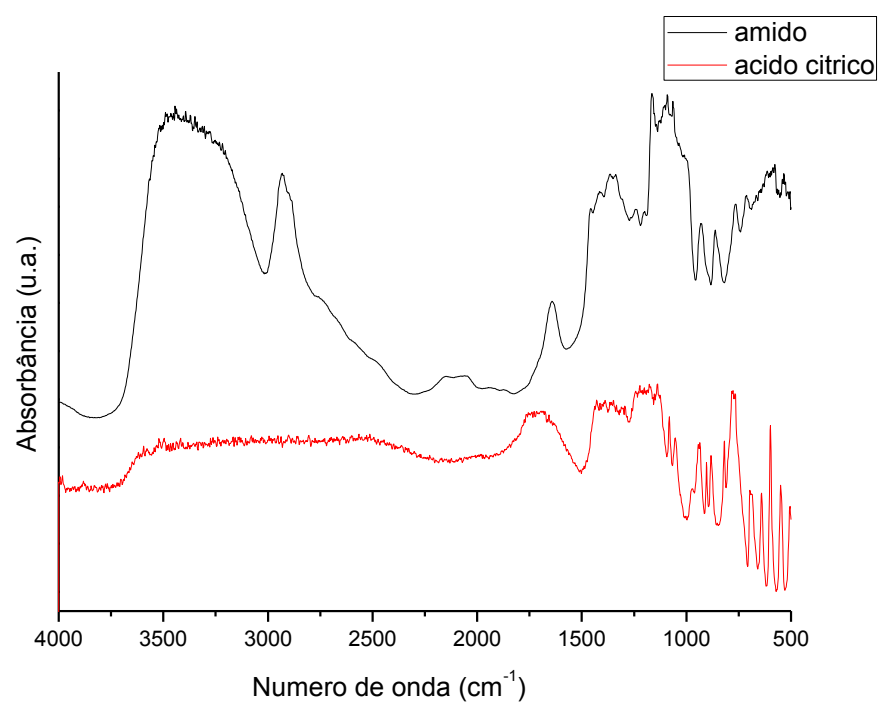

Analisando os espectros das amostras de TPS verificam-se alguns picos importantes: o pico em $1650 \mathrm{~cm}^{-1}$ corresponde ao amido quando forma ligações de hidrólise com a água, o pico em $3340 \mathrm{~cm}^{-1}$ representa a hidroxila. O ácido cítrico puro possui um pico em $1709 \mathrm{~cm}^{-1}$, que pode ser atribuído as ligações $\mathrm{C}=\mathrm{O}$ da carboxila, entretanto no TPS essa ligação é deslocada para $1730 \mathrm{~cm}^{-1}$, o que pode indicar ligações éster existente no TPS e reações de esterificação entre o amido e o ácido cítrico, entretanto é improvável que todos os grupos carboxila sofram reação de esterificação. 
Figura 33- Espectro FTIR das amostras de TPS preparadas.

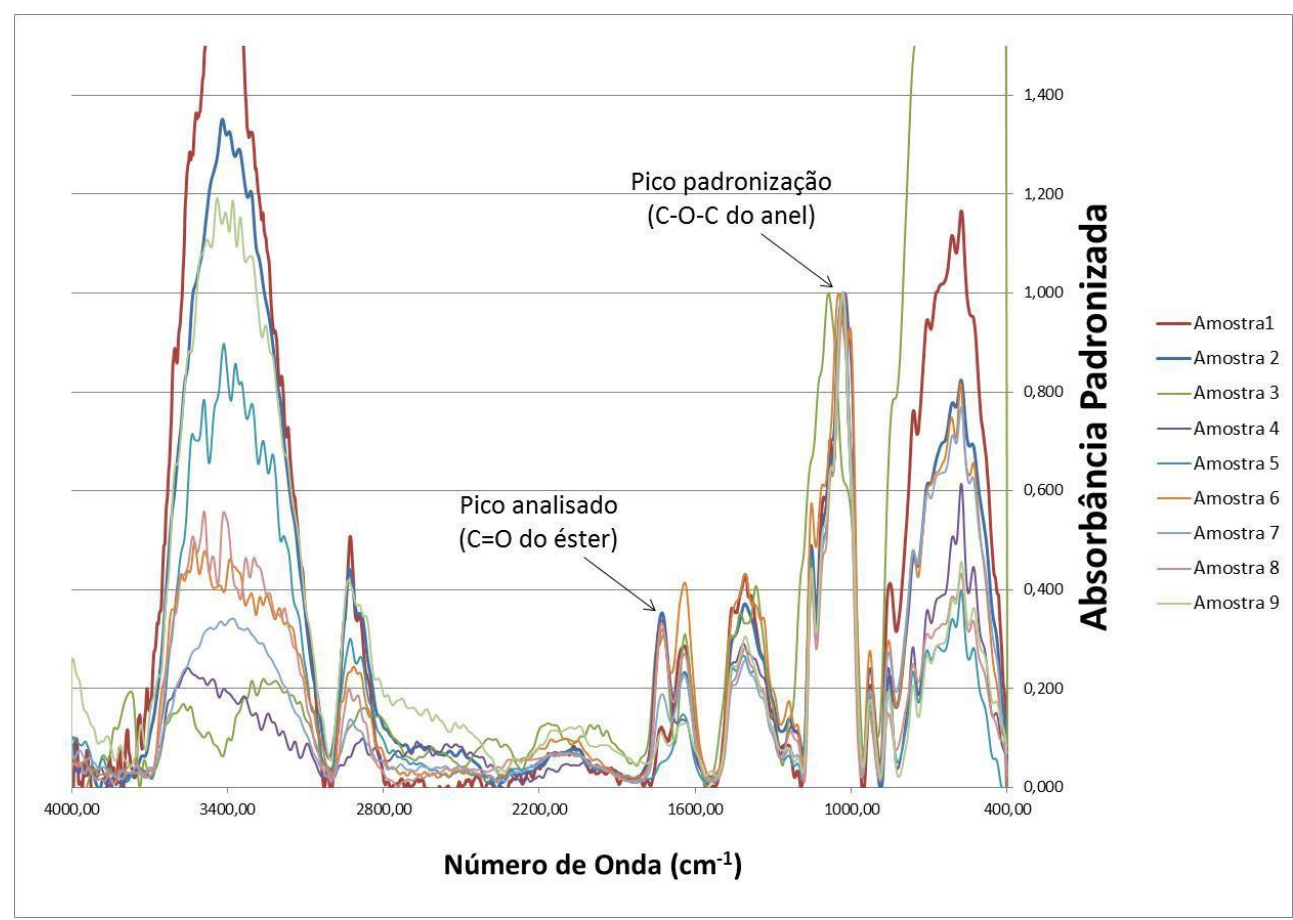

Para realizar a análise das áreas relativas dos picos 1730 e $1650 \mathrm{~cm}^{-1}$, que correspondem ao estiramento da ligação $\mathrm{C}=\mathrm{O}$ do éster, foram analisadas as áreas dos picos padronizadas em relação ao pico de $1030 \mathrm{~cm}^{-1}$ (correspondente à ligação C-O-C do anel anidroglicose), que se mantém constante em todas as amostras. Estes resultados são apresentados na Tabela 6.

Com a relação entre os picos, com $20 \%$ de umidade e $4 \%$ de ácido a 100rpm, foi realizado um tratamento dos dados por regressão, utilizando a ferramenta Solver do MS Excel. Foi obtido o modelo da Equação 9.

$$
\tau_{\text {final }}=0,2+-0,07 T^{*}-0,07 u^{*}+0,09 a^{*}+0,04 a^{* 2}-0,05 T^{*} u^{*}-0,11 T^{*} a^{*}+0,11 u^{*} a^{*}
$$

Onde: $\mathrm{T}$ = temperatura, $\mathrm{u}=$ umidade e $\mathrm{a}$ = ácido cítrico. 
Tabela 6 - Área relativa dos picos de éster dos espectros FTIR, para diferentes processamentos.

\begin{tabular}{|c|c|c|c|c|c|c|c|}
\hline & \multicolumn{2}{|c|}{$0 \%$ ácido } & \multicolumn{2}{|c|}{$4 \%$ ácido } & \multicolumn{2}{|c|}{$10 \%$ ácido } & \\
\hline \multirow{5}{*}{$\begin{array}{c}10 \% \\
\text { umidade }\end{array}$} & Mistura 1 & $100^{\circ} \mathrm{C}$ & Mistura 5 & $125^{\circ} \mathrm{C}$ & Mistura 9 & $150^{\circ} \mathrm{C}$ & \\
\hline & 1 & 0,122 & 5 & 0,062 & 9 & 0,111 & 100rpm \\
\hline & 10 & 0,256 & 14 & 0,071 & 18 & 0,119 & 150rpm \\
\hline & 19 & 0,233 & 23 & 0,086 & 27 & 0,148 & 100rpm \\
\hline & 28 & 0,222 & 32 & 0,098 & 36 & 0,139 & 150rpm \\
\hline \multirow{5}{*}{$\begin{array}{c}20 \% \\
\text { umidade }\end{array}$} & Mistura 2 & $125^{\circ} \mathrm{C}$ & Mistura 6 & $150^{\circ} \mathrm{C}$ & Mistura 7 & $100^{\circ} \mathrm{C}$ & \\
\hline & 2 & 0,353 & 6 & 0,320 & 7 & 0,189 & 100rpm \\
\hline & 11 & 0,191 & 15 & 0,230 & 16 & 0,229 & 150rpm \\
\hline & 20 & 0,212 & 24 & 0,715 & 25 & 0,254 & 100rpm \\
\hline & 29 & 0,292 & 33 & 0,728 & 34 & 0,171 & 150rpm \\
\hline \multirow{5}{*}{$\begin{array}{c}30 \% \\
\text { umidade }\end{array}$} & Mistura 3 & $150^{\circ} \mathrm{C}$ & Mistura 4 & $100^{\circ} \mathrm{C}$ & Mistura 8 & $125^{\circ} \mathrm{C}$ & \\
\hline & 3 & 0,308 & 4 & 0,338 & 8 & 0,332 & 100rpm \\
\hline & 12 & 0,419 & 13 & 0,408 & 17 & 0,561 & 150rpm \\
\hline & 21 & 0,562 & 22 & 0,362 & 26 & 0,451 & 100rpm \\
\hline & 30 & 0,721 & 31 & 0,387 & 35 & 0,278 & 150rpm \\
\hline
\end{tabular}

Fixando a temperatura em $125^{\circ} \mathrm{C}$, obteve-se o gráfico da Figura 34 . Nesse gráfico pode-se observar mais claramente a influência da variação da quantidade de ácido e umidade no torque final. Também se pode observar que com o aumento da quantidade de ácido e umidade, a relação entre as áreas aumenta, indicando que pode estar acontecendo uma maior cisão nas cadeias, o que acarreta na queda da viscosidade. 
Figura 34- Gráfico da relação entre os picos dos espectros de infravermelho em função das composições de ácido e umidade normalizadas, processadas à temperatura de 125 으, por 8 minutos e a $100 \mathrm{rpm}$.

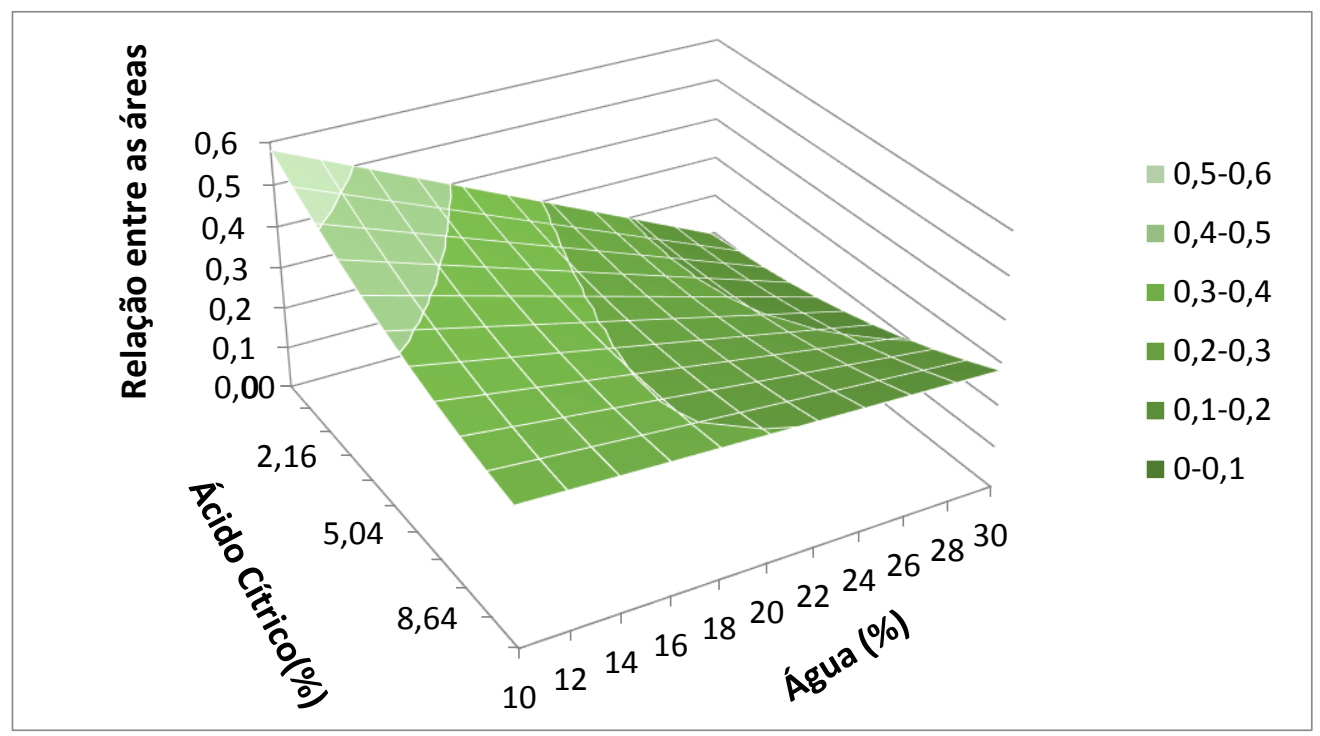

\subsubsection{Análise Termogravimétrica}

A Figura 35 mostra as curvas de DTG da mistura 1. Pode-se observar que há uma perda de massa a $200^{\circ} \mathrm{C}$, relativo a perda de glicerol. Uma segunda perda ocorre devido ao próprio ácido cítrico em $210^{\circ} \mathrm{C}$ e a última perda é relativa a degradação do amido a $270^{\circ} \mathrm{C}$. Não foram observadas diferenças significativas nas curvas de TG de amostras submetidas a diferentes tempos ou velocidades de mistura.

Figura 35- Curvas de DTG para as amostras da mistura 1.

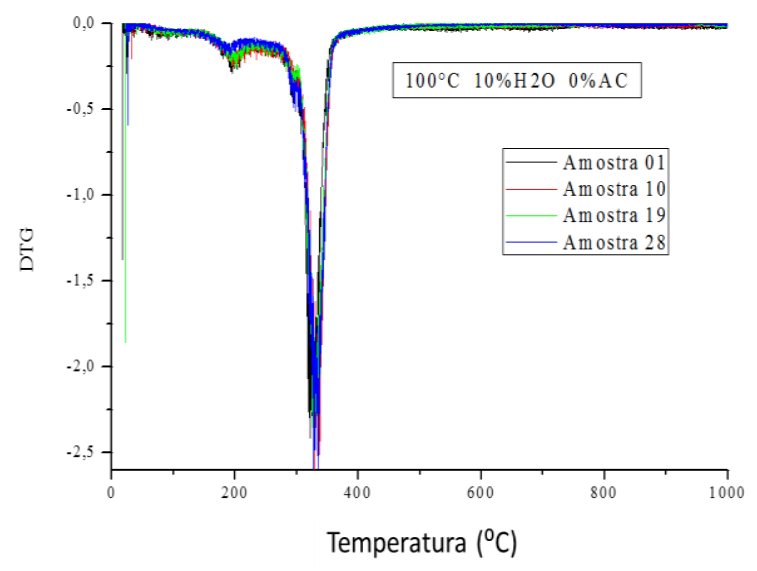


A temperatura na qual ocorre o mínimo no gráfico de DTG foi definida como a temperatura em que o processo de degradação é máximo. A partir destes valores foi novamente realizada a regressão quadrática dos dados, obtendo a Equação 10:

$$
\begin{gathered}
( \pm 4,1) \quad( \pm 2,5) \quad( \pm 1,7) \quad( \pm 2,2) \quad( \pm 3,2) \quad( \pm 2,9) \\
T_{\text {degrad }}=326,6+4,0 u^{*}-31,6 a^{*}-28,5 a^{* 2}+3,2 T^{*} u^{*}
\end{gathered}
$$

Onde: $T_{\text {degrad}}=$ temperatura de degradação, $\mathrm{u}=$ umidade e a=ácido cítrico .

Pela Equação 10 pode-se observar que o teor de ácido tem efeito bem maior na temperatura de degradação, por apresentar os maiores coeficientes. Pode ser visto que a temperatura de degradação é influenciada por um fator de 31 em relação a quantidade de ácido. Além disso, possui uma dependência quadrática, havendo assim um máximo dentro do intervalo estudado.

Fixando novamente a temperatura de processamento em $150^{\circ} \mathrm{C}$ e tempo de 8 minutos e 100 rpm, obteve-se o gráfico daFigura 36. Pelo gráfico pode-se observar que a temperatura de degradação aumenta com o aumento da umidade e a redução no teor de ácido.

Porém, para concentrações baixas de ácido, ocorre um aumento da temperatura de degradação, conforme o percentual de ácido aumenta. Este comportamento pode ser relacionado ao processo de esterificação, pois para baixas concentrações de ácido a força das ligações de hidrogênio promove uma melhor plastificação do amido. Isso influi diretamente nas propriedades do mesmo. Já em concentrações mais altas o ácido acaba provocando a cisão das cadeias de amido, reduzindo sua resistência à termodegradação. 
Figura 36- Gráfico da temperatura de degradação em função das composições de ácido e umidade normalizadas processadas à temperatura de $150^{\circ} \mathrm{C}$, por 8 minutos e a $100 \mathrm{rpm}$.

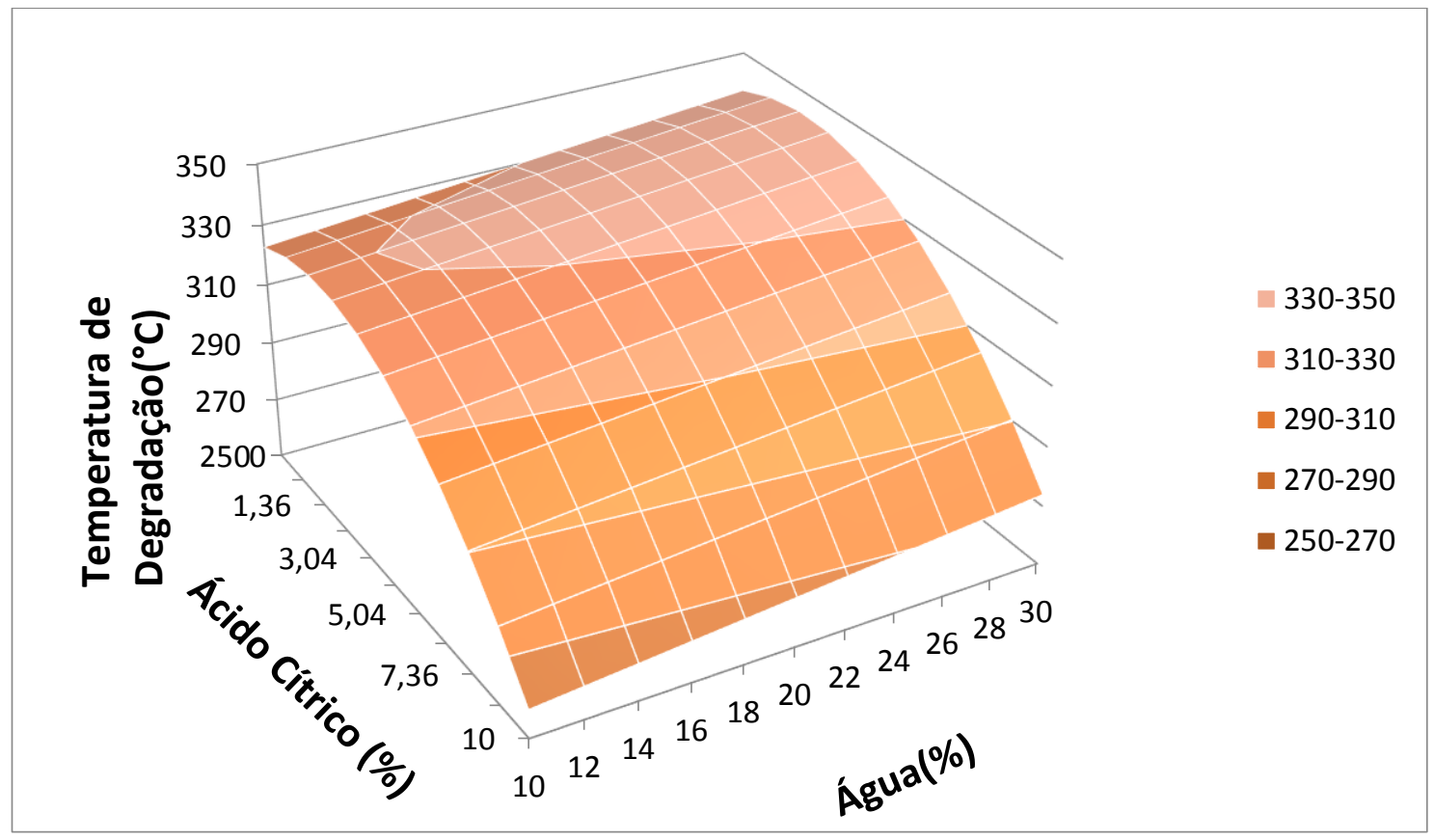

Utilizando a ferramenta SOLVER do Microsoft Excel foram obtidos os máximos e mínimos da função, como mostra a Tabela 7. Tem-se um máximo de temperatura de degradação para uma composição de $30 \%$ de umidade e $1,6 \%$ de ácido, processada a $150^{\circ} \mathrm{C}$.

Para essas condições de processamento, e considerando misturas preparadas a $100 \mathrm{rpm}$ por 8 minutos, temos um torque final de 0,53 $\mathrm{Nm}$. Têm-se misturas que oferecem menor resistência ao fluxo (menor viscosidade), com maior resistência à termodegradação

A temperatura de degradação não é um parâmetro muito utilizado para seleção de materiais. Todavia, uma maior resistência à termodegradação influencia diretamente no processamento, aumentando a janela de temperatura de processamento. Também há influência indireta em outras propriedades, pois uma maior resistência química à ação da temperatura pode indicar forças inter e intramoleculares mais intensas, deixando o material mais coeso e resistente a outros efeitos (como corrosão, resistência à tração e ao impacto, dentre outros). 
Tabela 7- Temperatura de degradação mínima e máxima para 100rpm e 8 min.

\begin{tabular}{ccc|cc}
\hline $\mathbf{T}(\mathbf{O} \mathbf{C})$ & $\mathbf{u}(\%)$ & $\mathbf{a}(\%)$ & $\mathbf{T}_{\text {degrad }}$ & \\
\hline 150 & 10 & 10 & 260 & Mín. \\
150 & 30 & 1,6 & 344 & Máx. \\
\hline
\end{tabular}

\subsubsection{Microscopia Eletrônica de Varredura (MEV)}

Na Figura 37 pode-se ver um exemplo de morfologia observada em MEV das amostras $20\left(125^{\circ} \mathrm{C}, 10 \%\right.$ de umidade $)$ e $24\left(150^{\circ} \mathrm{C}\right.$ e $20 \%$ de umidade). A micrografia da Figura 37a mostra uma superfície fraturada por mecanismo dúctil e com microcavidades (dimples) isso ocorre pois o TPS possui duas fases, uma rica em amido e outra rica em glicerol, o que será explicado um pouco mais a frente ao se discutir sobre os ensaios de DSC . Porém não foram observados grânulos de amido de milho em nenhuma das amostras, evidenciando que houve desestruturação do amido. Então, é possível assegurar que as amostras apresentaram homogeneidade.

As imagens obtidas por MEV são mostradas na Tabela 8. Verifica-se que com o aumento do teor de água e da temperatura, as amostras começam a ficar mais homogêneas, nota-se uma redução ou desaparecimento dos grânulos de amido.

Figura 37- MEV com $1000 x$ de aumento das amostras (a) 20 (150ㄷ e 10\% umidade) e (b) 24 (125C e $20 \%$ umidade), ambas com $4 \%$ de ácido cítrico e processadas por 15 min a 100rpm.

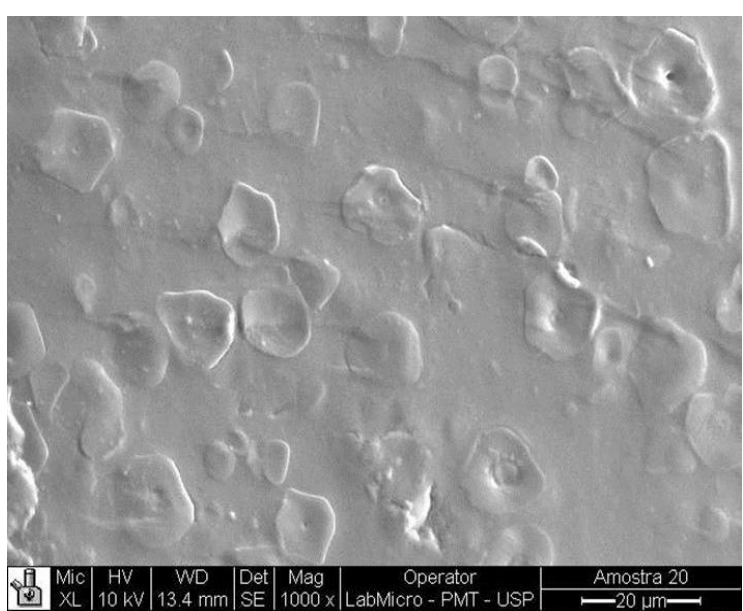

(a)

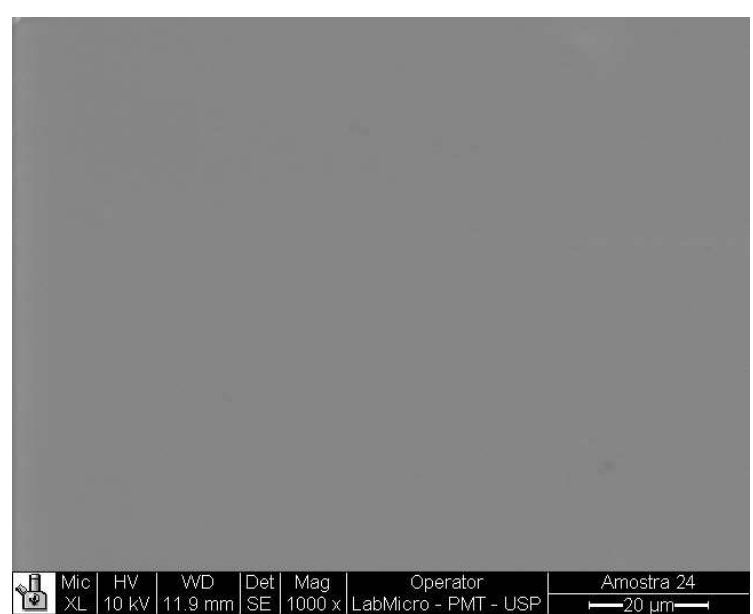

(b) 
Tabela 8- Imagens de MEV para as amostras processadas por $8 \mathrm{~min}$ e 100rpm.

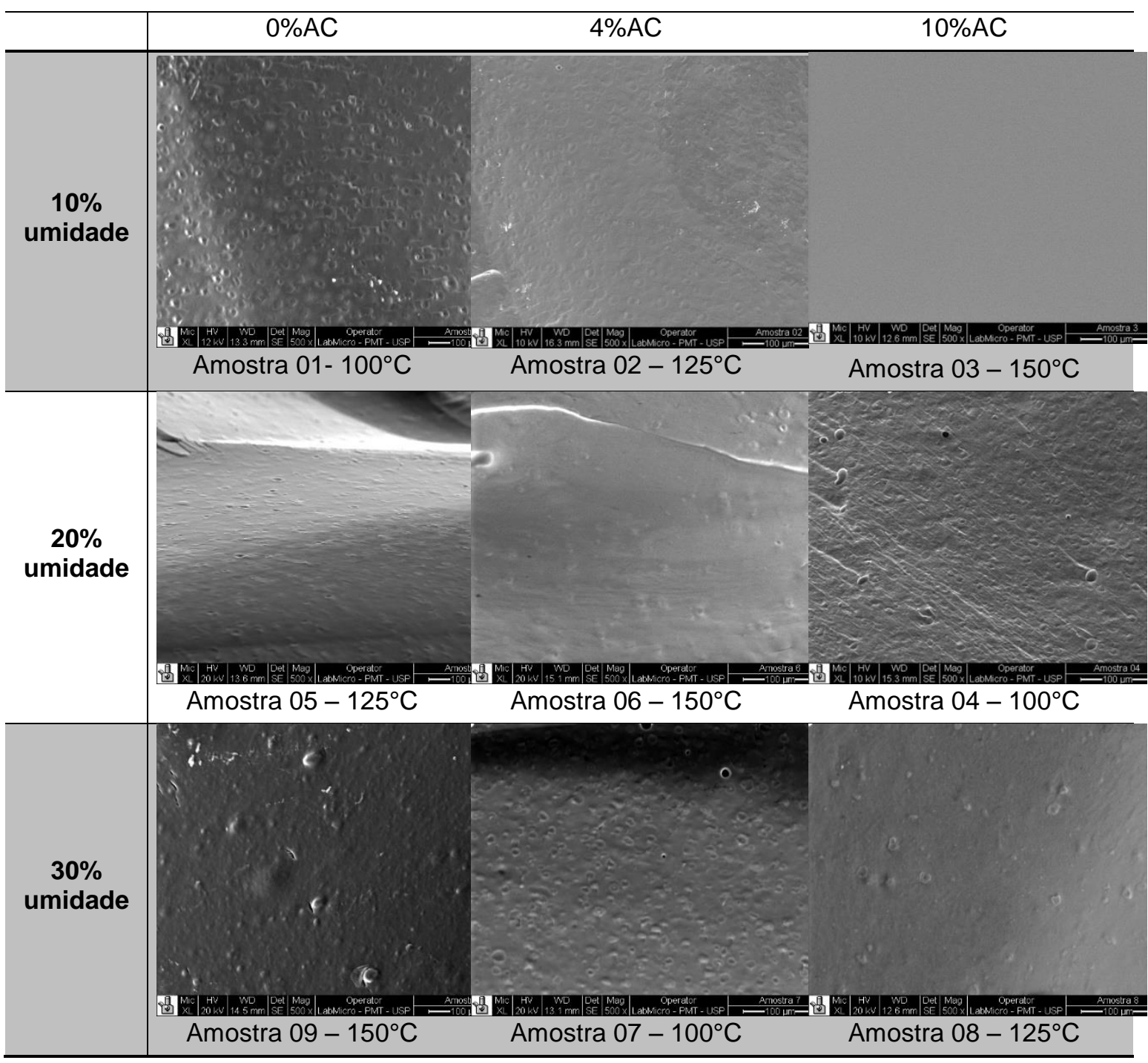

É necessário tomar cuidado, pois algumas amostras, como as da mistura 3, são muito pegajosas na temperatura ambiente, e mesmo sendo criofraturadas, ao voltarem à temperatura ambiente, voltam às condições iniciais, e por isso a superfície da amostra é lisa.

Como esperado, o aumento na umidade melhorou a gelatinização e homogeneização do amido, já que a água é um plastificante. $O$ ácido, por reduzir as forças intermoleculares (devido à esterificação), também auxiliou na gelatinização. $A$ temperatura de processamento apesar de não ter influência muito marcante, também 
ajudou na gelatinização, pois com o aquecimento, a difusão da água na estrutura do amido é facilitada.

\subsubsection{Etapa II: Novas composições de TPS com ácido cítrico}

A partir dos dados obtidos nos ensaios acima descritos, foram processadas três novas composições (7mod, AC2 e AC3). Os parâmetros dessas composições estão representados na Tabela 9.

Tabela 9- Tabela dos parâmetros das novas composições AC2, AC3 e 7mod e da composição

7.

\begin{tabular}{c|ccccc}
\hline Amostra & $\begin{array}{c}\text { Temperatura } \\
\left({ }^{\circ} \mathbf{C}\right)\end{array}$ & $\begin{array}{c}\text { Umidade } \\
(\%)\end{array}$ & $\begin{array}{c}\text { Ácido } \\
(\%)\end{array}$ & $\begin{array}{c}\text { Tempo } \\
(\mathbf{m i n})\end{array}$ & $\begin{array}{c}\text { Vel. dos rot. } \\
(\mathbf{r p m})\end{array}$ \\
\hline AC2 & 125 & 20 & 2 & 8 & 100 \\
AC3 & 125 & 30 & 2 & 8 & 100 \\
7mod & 125 & 30 & 4 & 8 & 100 \\
7 & 100 & 30 & 4 & 8 & 100 \\
\hline
\end{tabular}

Foi utilizada uma composição com $2 \%$ em massa de ácido, pois nos ensaios observou-se que a presença de maior teor de ácido torna a mistura pegajosa, com baixa temperatura de degradação, sendo inadequada para o processamento. Já com pouco ácido, os materiais apresentam difícil processabilidade. A partir da análise termogravimétrica determinou-se que a composição ótima era aquela com 1,53\% em massa de ácido. Como há imprecisões durante o processamento, e erros no modelamento matemático, usou-se uma composição aproximada de $2 \%$ em massa de ácido. Para analisar o efeito do ácido foram preparadas as amostras AC3 e $7 \mathrm{mod}$.

Analisando os ensaios, notou-se que para ocorrer a plastificação é necessário um maior teor de umidade. Como os ensaios não foram conclusivos, quanto a uma composição ótima do teor de água, foram feitas duas amostras (uma com $20 \%$ e outra com $30 \%$ em massa de umidade). Para analisar o efeito da umidade foram preparadas duas amostras: AC2 e AC3. 
Foi observado que as misturas preparadas a 100 rpm, e 8 minutos de processamento, já haviam obtido o pico indicando a gelatinização. Então, não houve necessidade de se aumentar os valores destes parâmetros, sendo utilizados os valores mínimos dos parâmetros.

Para a temperatura foi utilizado o valor intermediário, $125^{\circ} \mathrm{C}$, cujas amostras apresentaram melhor homogeneidade e processabilidade. Porém, para analisar o efeito da temperatura, foram utilizadas as amostras 7 e $7 \mathrm{mod}$.

\subsubsection{Curva de Torque}

A Figura 38 mostra as curvas de torque em função do tempo para as amostras AC2, AC3, 7 e $7 \mathrm{mod}$. Todas as amostras possuem o primeiro pico de carregamento e o segundo pico, que indica a ocorrência de gelatinização. Comparando as amostras AC2 e AC3, verifica-se que quanto maior o teor de água, menor o torque, o que já é esperado devido a maior mobilidade das moléculas. Observa-se que a amostra 7, que possui menor temperatura de processamento possui um pico de gelatinização mais largo isso ocorre pois, com baixo valor de temperatura, torna-se mais difícil a quebra das moléculas.

Figura 38 - Curvas de Torque em função do tempo para as amostras 7, 7mod, AC2 e AC3.

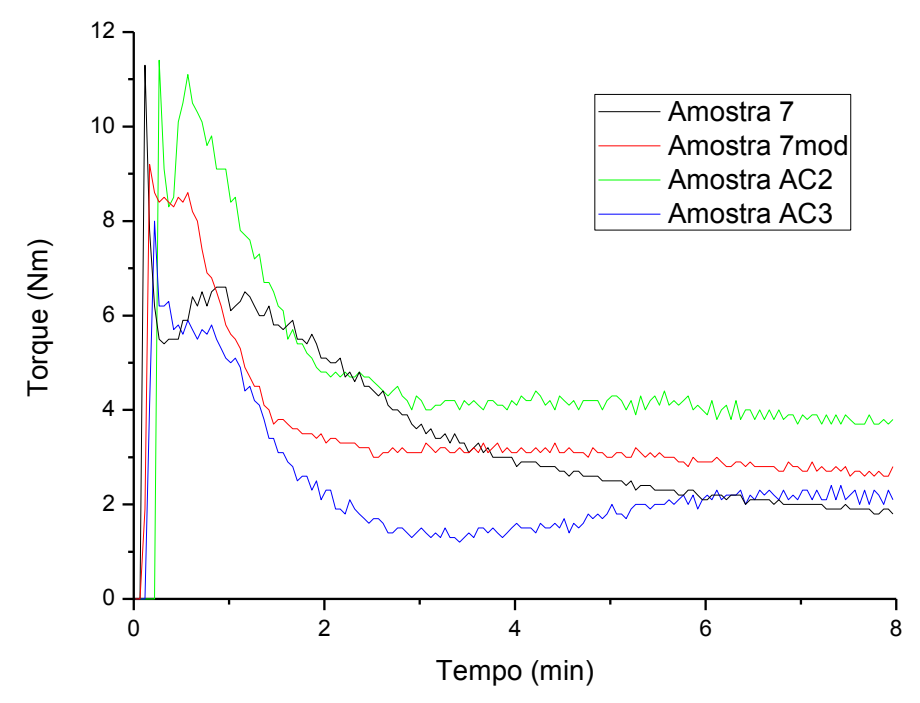


3.4.2.2 Espectroscopia Vibracional de Absorção no infravermelho com transformada de Fourier (FTIR)

A Figura 39 mostra os espectros de FTIR para as amostras de amido puro, 7, 7mod, AC2 e AC3. Nota-se que não existe mudança nos grupos funcionais ester. $E$ a relação entre os picos 1730 e $1030 \mathrm{~cm}^{-1}$ está entre 0,737 e 0,834, ou seja, não apresentam uma mudança significativa. Porém, é necessário verificar o teor de ácido que realmente faz parte da reação e forma grupo éster, ou a quantidade de ácido que não reagiu. Para isto foi analisado o grau de substituição e de esterificação na seção 3.4.2.8.

Figura 39 - Espectros FTIR para as amostras 7, 7mod, AC2 e AC3.

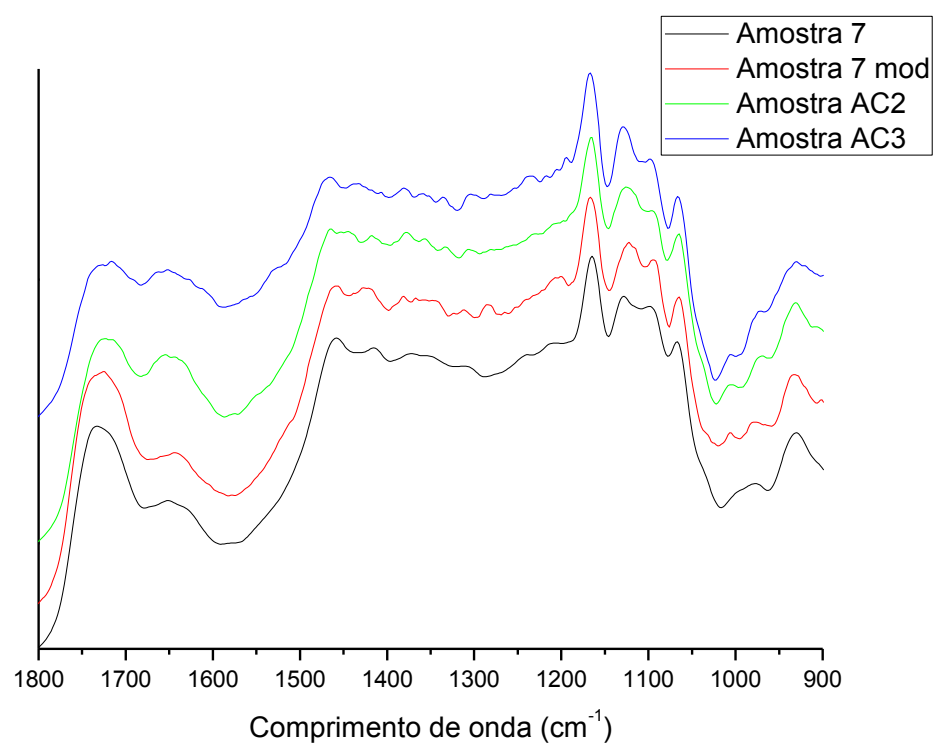

\subsubsection{Análise Termogravimétrica}

A Figura 40 mostra as curvas de TG e DTG para as amostras 7, 7mod, AC2 e AC3. Nota-se que todas as amostras possuem uma pequena perda de massa até $115^{\circ} \mathrm{C}$, que corresponde a água adsorvida. Acima da temperatura de $115^{\circ} \mathrm{C}$ pode-se observar que a perda de massa ocorre em três estágios distintos. O primeiro estágio corresponde ao glicerol, o segundo ao ácido cítrico e o terceiro ao amido. Verifica-se 
ainda que a temperatura de $500^{\circ} \mathrm{C}$, todas as curvas apresentam massa residual de cerca de $8 \%$, correspondente ao material carbonáceo $[40,41,42,43]$

Figura 40 - Curvas de (a) TG e (b) DTG para as amostras 7, 7mod, AC2 e AC3.

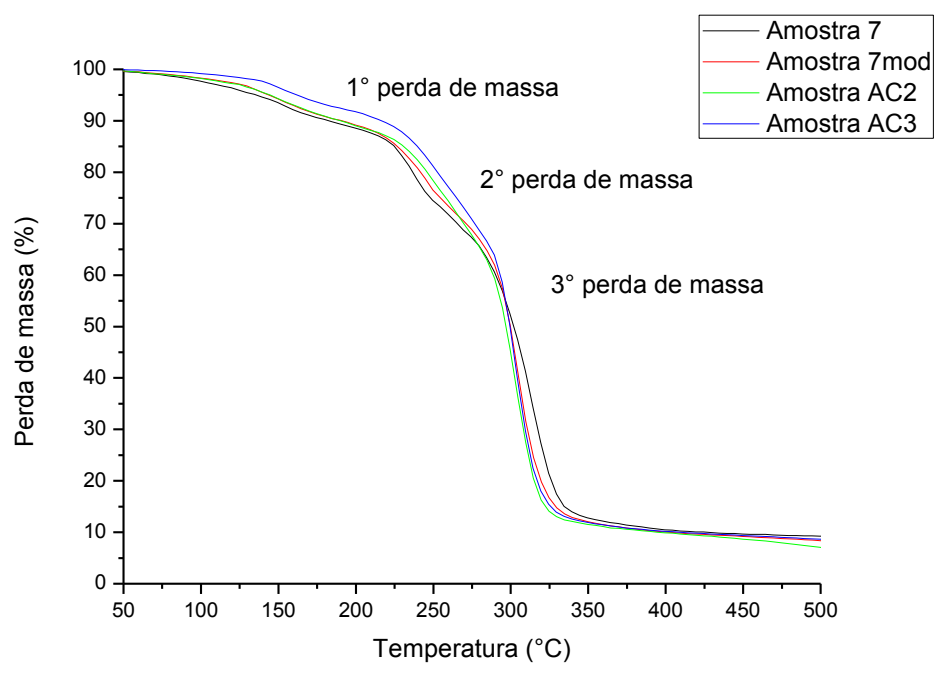

(a)

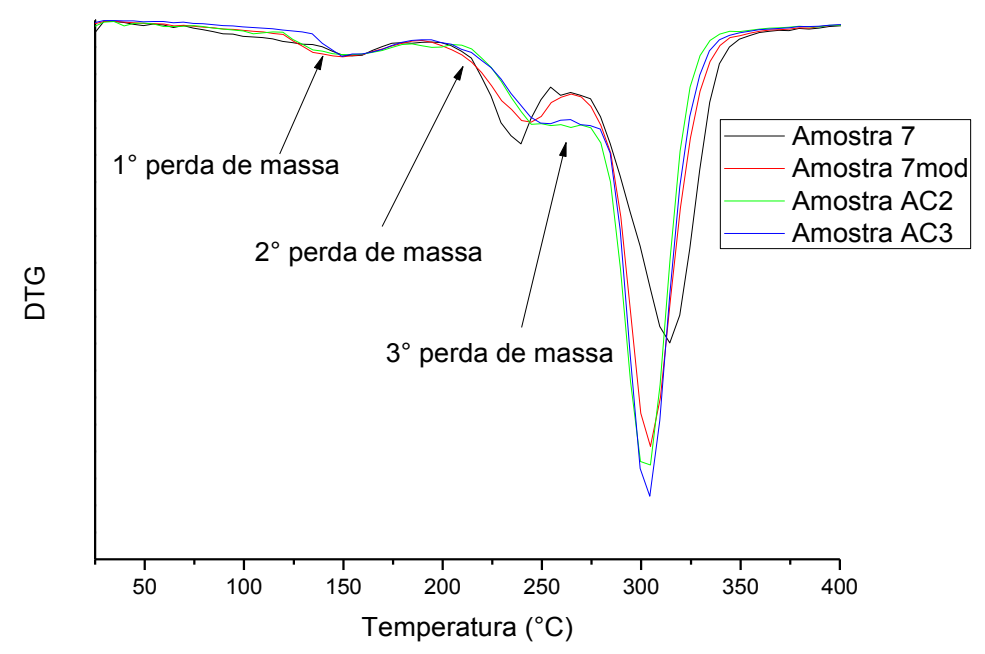

(b)

Em relação à primeira perda de massa, referente ao glicerol, as amostras AC2 e AC3 possuem o início da perda de massa em $120^{\circ} \mathrm{C}$ e $125^{\circ} \mathrm{C}$, respectivamente, mostrando que o teor de água não influencia na degradação do glicerol. Em relação ao teor de ácido, verifica-se que com mais ácido o início da perda de massa ocorre em uma temperatura mais baixa, como visto na amostra $7 \mathrm{mod}$, onde a perda de 
massa inicia em $120^{\circ} \mathrm{C}$. Em relação à temperatura de processamento, ao diminuir a temperatura, o início da perda de massa ocorre em uma temperatura um pouco alta, como mostra a amostra 7 , que inicia em $135^{\circ} \mathrm{C}$. Nota-se que quanto maior a quantidade de ácido cítrico menor a temperatura em que se inicia a degradação do glicerol.

Considerando o segundo estágio de perda de massa, referente ao ácido cítrico, todas as amostras tiveram temperaturas iniciais semelhantes, em aproximadamente $210^{\circ} \mathrm{C}$.

Já para a terceira perda de massa $(90 \%)$, a temperatura inicial de degradação é maior quanto menor a quantidade de ácido, o que já havia sido verificado no planejamento estatístico. Comparando a amostra 7, que possui uma temperatura de processamento mais baixa, com a $7 \mathrm{mod}$, nota-se que apesar de começarem a degradar na mesma temperatura, o final da degradação ocorre em temperaturas mais elevadas para a amostra 7.

\subsubsection{Calorimetria Exploratória Diferencial (DSC)}

A Tabela 10 mostra os resultados da análise realizada por DSC. Em amidos plastificados com glicerol, estudos mostram a ocorrência de três transições térmicas: uma relativa ao processo de relaxação $\alpha$, associada a $T_{g}$, atribuída a relaxação da fase rica em glicerol, outra a temperaturas menores que a $T_{g}$, conhecida como transição secundária, sub $T_{g}$, referente ao processo de relaxação $\beta$, relacionado a movimentações moleculares localizadas, devido a relaxação da fase rica em amido, e a terceira relacionada a $\mathrm{Tm}_{\mathrm{m}}$ [99][100][101].

A $T_{g}$ do TPS é dependente da composição do material, tipo e quantidade de plastificante. Por isto ocorrem variações nos valores da $T_{g}$ relatados na literatura [102][103][104].

Experimentalmente não é possível obter a $\mathrm{Tg}$ do amido seco, devido a degradação térmica [105], mas, utilizando a extrapolação das temperaturas de transição de vidro de malto-oligossacáridos com diferentes graus de polimerização, Orford et al. [106] estimou a $\mathrm{T}_{\mathrm{g}}$ do amido seco em aproximadamente $230^{\circ} \mathrm{C}$. 
Tabela 10 - Temperatura de Transição Vítrea (Tg) e temperatura de fusão $\mathrm{Tm}$ das amostras 7, $7 \mathrm{mod}, \mathrm{AC2}$ e AC3

\begin{tabular}{c|ccc}
\hline Amostra & Sub- $\mathrm{Tg}_{\mathrm{g}}\left({ }^{\circ} \mathrm{C}\right)$ & $\mathrm{T}_{\mathrm{g}}\left({ }^{\circ} \mathrm{C}\right)$ & $\mathrm{T}_{\mathrm{m}}\left({ }^{\circ} \mathrm{C}\right)$ \\
\hline $\mathbf{7}$ & -90 & 54 & 89 \\
$\mathbf{7 m o d}$ & -88 & 49 & 153 \\
AC2 & -86 & 40 & 92 \\
AC3 & -83 & 43 & 86 \\
\hline
\end{tabular}

Comparando as amostras AC2 e AC3, verifica-se que ao aumentar o teor de água houve um decréscimo nos valores de $T_{g}$. $O$ mesmo comportamento foi observado por Forsell et al. [100]. Isso pode ocorrer, pois, ao aumentar o teor de água a mobilidade da molécula aumenta. Além disto, houve uma queda nos valores de $T_{\mathrm{m}}$, o que ocorre devido às ligações intermoleculares. E então, ao colocar mais água no TPS, há uma maior separação das moléculas, facilitando a fusão do material.

Comparando as amostras 7 e 7 mod pode-se verificar o efeito da temperatura de processamento. Esta afeta de maneira quase imperceptível a segunda $T_{g}$, quanto maior a temperatura de processamento menor a $T_{g}$, pois pode ocorrer quebra de cadeia durante o processo. A temperatura de processamento também modifica a $T_{m}$, quanto maior a temperatura $\left(125^{\circ} \mathrm{C}\right)$ mais alta a $\mathrm{T}_{\mathrm{m}}$.

Comparando as amostras AC3 e 7 mod pode-se analisar o efeito do teor de ácido. Para 2 e $4 \%$ em massa de ácido, verifica-se uma mudança muito pequena nos valores de $T_{g}$ e uma mudança expressiva da $T_{m}$ dos materiais. Isso pode ocorrer devido às reações de acidólise.

\subsubsection{Difração de Raios X (DRX)}

A análise por técnica de difração de raios $X$ permite distinguir os três tipos de hábito cristalino presentes nos grânulos de amido que, dependendo de sua forma $\mathrm{e}$ estrutura cristalina, denominam-se A, B e C [41, 42]. Estes padrões de cristalinidade dependem, em parte, do comprimento das cadeias de amilopectina, da densidade de empacotamento dentro dos grânulos, bem como da presença de água [109]. 
A Figura 41 apresenta o DRX do amido de milho. Observa-se picos em $2 \theta$ igual a: $15^{\circ}, 17^{\circ}, 18^{\circ}$ e $23^{\circ}$, o que caracteriza uma estrutura do tipo A. Esta estrutura é comum para amidos de cereais e possui comprimento de cadeias de amilopectina de 23-29 unidades de glicose. As ligações de hidrogênio entre os grupos hidroxil das moléculas das cadeias de amiilopectina resultam na formação de uma estrutura helicoidal dupla. Entre essas micelas, as cadeias lineares de amilose são empacotadas formando ligações de hidrogênio com outras cadeias lineares de amilopectina $[44,45,46]$.

Figura 41 - Curva de DRX do amido de milho.

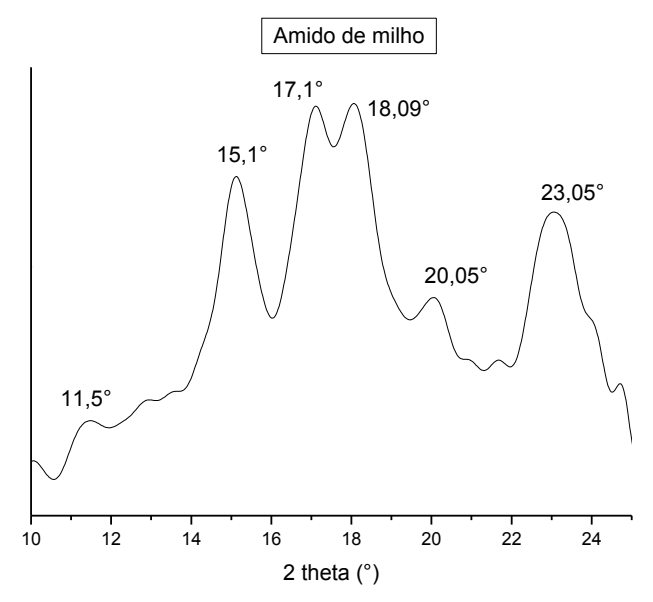

A estrutura do tipo $B$ é característica para amido de tubérculos e amidos ricos em amilose. Possui comprimentos de cadeia de amilopectina entre 30-44 moléculas de glicose com água. Este é o padrão usual de amidos de batata crua e banana. Os picos $2 \theta$ típicos dessa estrutura são encontrados em: $5,6^{\circ}, 14,4^{\circ} ; 17,2^{\circ} ; 22,2^{\circ} \mathrm{e}$ $24^{\circ}[43,46,47]$.

A estrutura do tipo $C$ é conhecida como uma mistura dos diagramas do tipo $A$ e o tipo $B$ e é característica da maioria dos amidos de legumes, e também de cereais que cresceram em condições específicas de temperatura e hidratação. Como exemplo de materiais que possuem essa estrutura, pode-se citar o amido de ervilha e de feijão. A estrutura é composta de comprimentos de cadeia de amilopectina entre 26-29 moléculas de glicose. Os picos $2 \theta$ típicos desta estrutura são encontrados em $5,6^{\circ}$, $15,3^{\circ} ; 17,3^{\circ}$ e $23,5^{\circ}[43,48,49,50]$. 
Uma forma adicional, chamado tipo V, ocorre em grânulos inchados, formado pela cristalização da amilose com lipídios, e apresentam picos de intensidade nos ângulos de difração $2 \theta$ em aproximadamente $12,6^{\circ}, 13,2^{\circ}, 19,4^{\circ}$ e $20,6^{\circ}$ [43,51].

A Figura 42 mostra as curvas de DRX para as amostras 7, 7mod, AC2 e AC3. A morfologia e a estrutura do amido termoplástico são determinadas pelo nível de cisões e de fusão do amido. E o grau de rompimento do amido é influenciado: pelo teor de plastificante (água, glicerol e ácido cítrico) e pelos parâmetros de processamento [117].

Figura 42 - Curvas de DRX para as amostras 7 e $7 \bmod (a)$ e AC2 e AC3 (b).

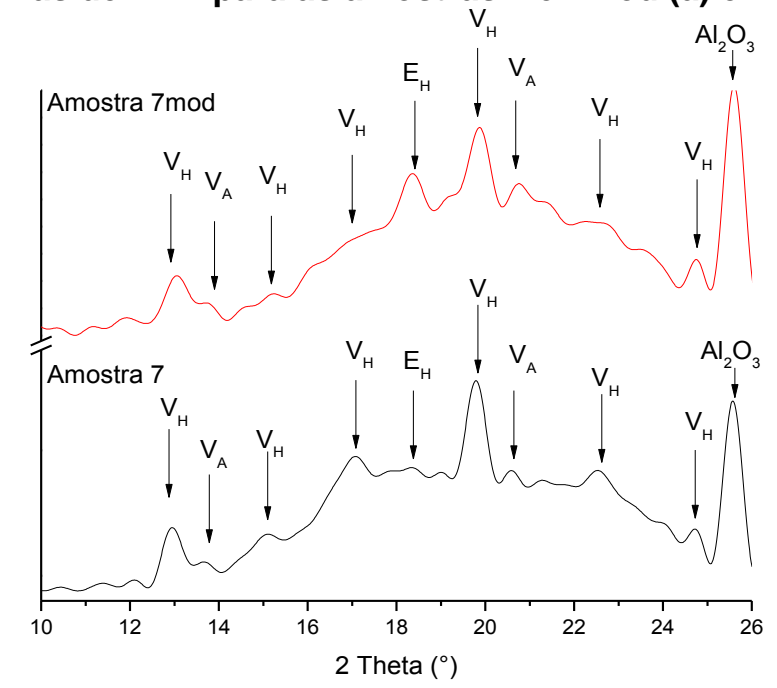

(a)

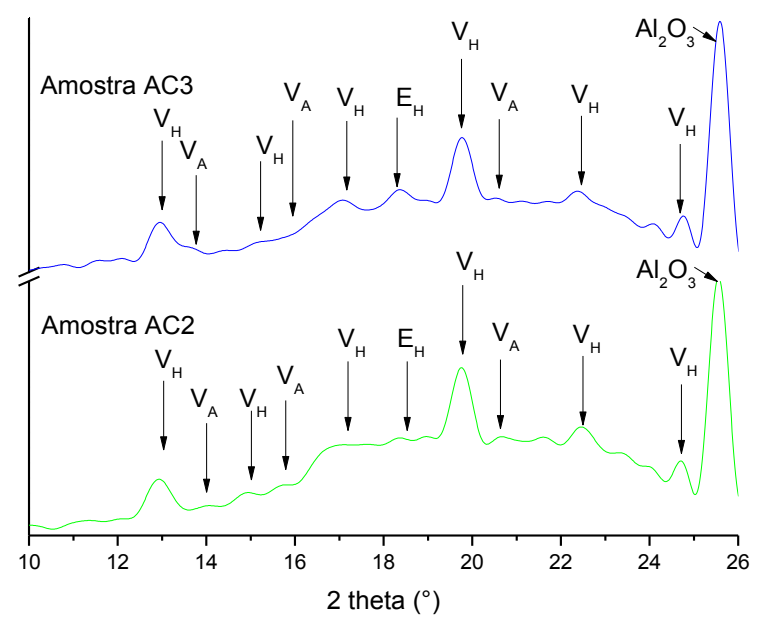

(b) 
A cristalinidade que ocorre durante o processamento é causada pela rápida recristalização das estruturas helicoidais simples da amilose. Podem ser observadas três tipos de cristais: $V_{H}, V_{A}$ e $E_{H}$. Estas estruturas cristalinas têm padrões característicos de difração de raios $\mathrm{X}$, devido a diferenças na estrutura cristalina $\mathrm{e}$ hidratação. A formação de hélices simples é determinada, principalmente, pelas variáveis do processo, do teor de amilose e aditivos. Durante o processamento, um aumento da energia mecânica, ocasionada pelo cisalhamento provocado pelos rotores, ou com o tempo de processamento, provoca um aumento na quantidade de hélices simples. As quantidades relativas das várias estruturas helicoidais simples de amilose e a taxa de variação são influenciadas pela temperatura e umidade [117].

Sabe-se que a presença de amilose induz a cristalização da amilopectina. Isso pode ocorrer, influenciando a amilopectina a cristalizar por si própria ou por cocristalização entre amilose e amilopectina. À medida que a estrutura cristalina é construída de hélices duplas ordenadas, os co-cristais podem se formar de duas formas distintas: através dos arranjos de hélices duplas de amilose - amilopectina ou pelas duplas hélices de amilose com cadeias interligadas a amilopectina [118].

$\mathrm{Na}$ Figura 42 pode-se encontrar os três tipos de estrutura mencionados, $\mathrm{V}_{\mathrm{H}}, \mathrm{V}_{\mathrm{A}}$ e $E_{H}$. Entretanto, em todas as amostras predominam estruturas $V_{H}$. Este resultado corrobora com o apresentado por Le Bail et al. [119]. Ao adicionar ácido cítrico no TPS, os cristais do tipo $V_{A}$ e $E_{H}$, que são produzidos durante o processamento e possuem estruturas helicoidais típicas dos complexos formados entre a amilose e os lípidos presentes no amido, são cristais instáveis. Logo, deixam de existir e são formadas estruturas do tipo $\mathrm{V}_{\mathrm{H}}$, devido a melhor mobilidade das cadeias.

Os cristais $\mathrm{V}_{H}$, possuem a ligação $\alpha-1,6$ onde a hélice gira para a esquerda, formando uma cela ortorrômbica com parâmetros de dimensões $a=13,65 \AA$, $b=23,70$ $\AA$ e $\mathrm{c}=8,05 \AA$ [120] ou uma cela unitária hexagonal com as dimensões: $\mathrm{a}=\mathrm{b}=13,65$ $\AA$ e $\mathrm{C}=8,05 \AA$ e os valores encontrados para $2 \theta$ nas amostras foram de $13 ; 15 ; 17$; 19,$8 ; 22,2$ e $25^{\circ}[121]$.

Os cristais $\mathrm{V}_{\mathrm{A}}$ possuem uma cela unitária ortorrômbica com as dimensões: $\mathrm{a}=$ $13,0 \AA, b=22,5 \AA$ e $c=7,9 \AA$ (parâmetros baseados no DRX de uma fibra) [122]. O padrão $V_{A}$ possui hélices de amilose mais contraídas e com menos água do que a 
rede $\mathrm{V}_{\mathrm{H}}$. Formas intermediárias de $\mathrm{V}_{\mathrm{H}}$ e $\mathrm{V}_{\mathrm{A}}$ são conhecidas e ocorrem provavelmente pelas diferenças na hidratação da célula unitária. Os valores encontrados para $2 \theta$ nas amostras foram 13,6; 15,8 e 20,8[123].

Os cristais $E_{H}$ possuem amilose na forma de hélice simples. Na forma seca descreve-se uma estrutura hexagonal com as dimensões $a=b=14,7 \AA$, e na forma úmida, possui uma hélice na ligação $\alpha-1,6$ e cela unitária ortorrômbica com as dimensões: $a=28,3 \AA$, $b=29,3 \AA$ e $c=8,0 \AA$. Em geral, os TPS processados possuem cristalitos de dimensões maiores [54,57]. O único valor encontrado para $2 \theta$ nas amostras foi $18,4^{\circ}$.

Observa-se que devido ao maior teor de ácido residual das amostras 7 e $7 \mathrm{mod}$, os picos dos cristais $V_{A}$ estão mais definidos, indicando menor interação entre o amido e os plastificantes. Ao analisar a temperatura de processamento, considerando $4 \%$ de ácido e $30 \%$ de umidade as estruturas $V_{H}$ estão mais definidas na amostra 7 , na qual a temperatura de processamento foi menor. Comparando o teor de água, verifica-se que a amostra com $20 \%$ de umidade possui os picos $\mathrm{V}_{H}$ mais definidos.

\subsubsection{Microscopia Eletrônica de Varredura (MEV)}

A Figura 43 mostra as imagens obtidas por MEV das amostras 7, 7mod, AC2 e AC3. Nenhuma das amostras possui grânulos de amido inteiros, indicando que todos os grânulos foram plastificados, comprovando o resultado obtido nas curvas de torque. Pode-se notar que a amostra 7 mod possui uma estrutura mais lisa, evidenciando 0 efeito da temperatura. Dentre as amostras AC2 e AC3, a amostra AC3 está mais homogênea, o que pode indicar uma melhor plastificação. 
Figura 43 - Imagens de MEV das amostras 7(a), $7 \bmod (b), A C 2(c)$ e AC3(d).

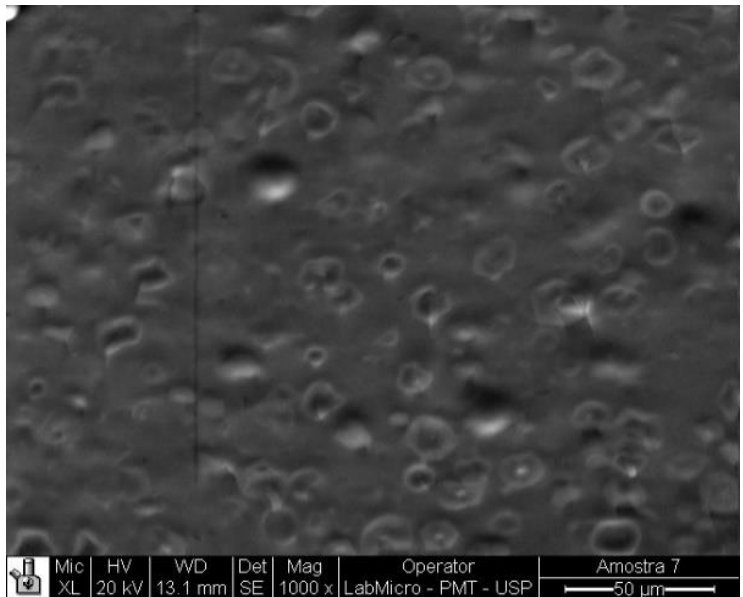

(a)

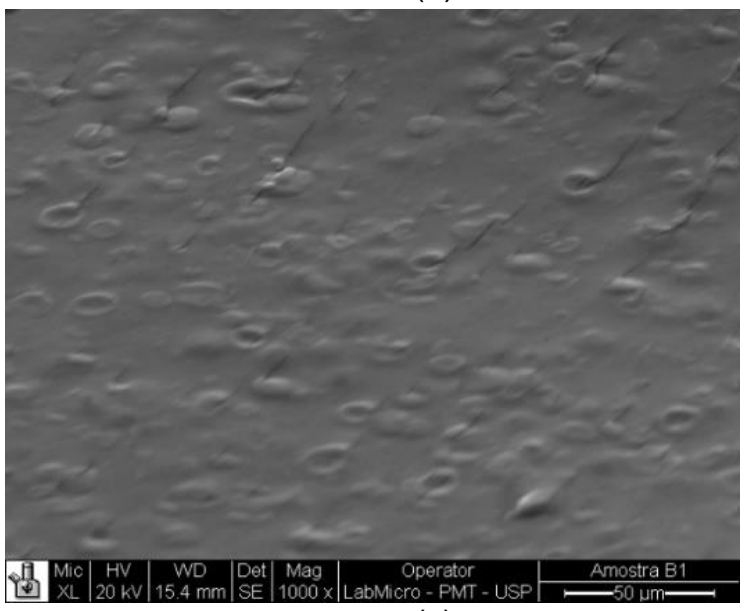

(c)

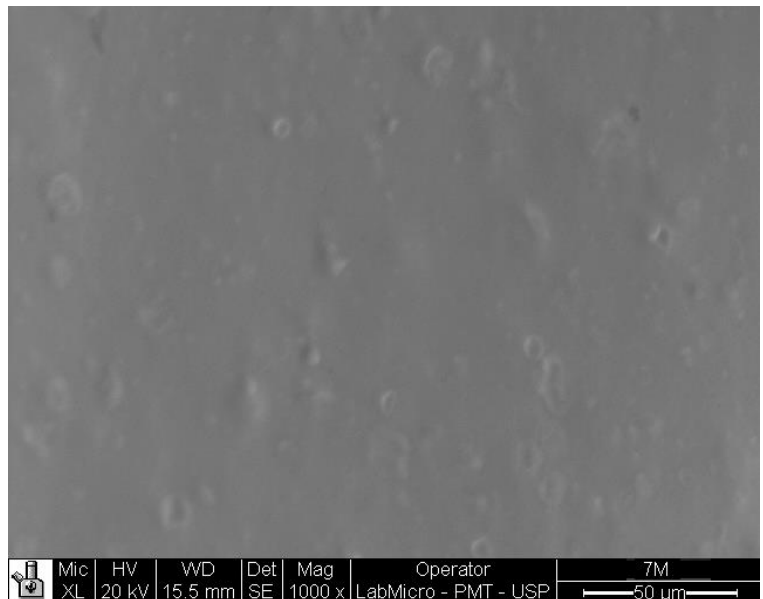

(b)

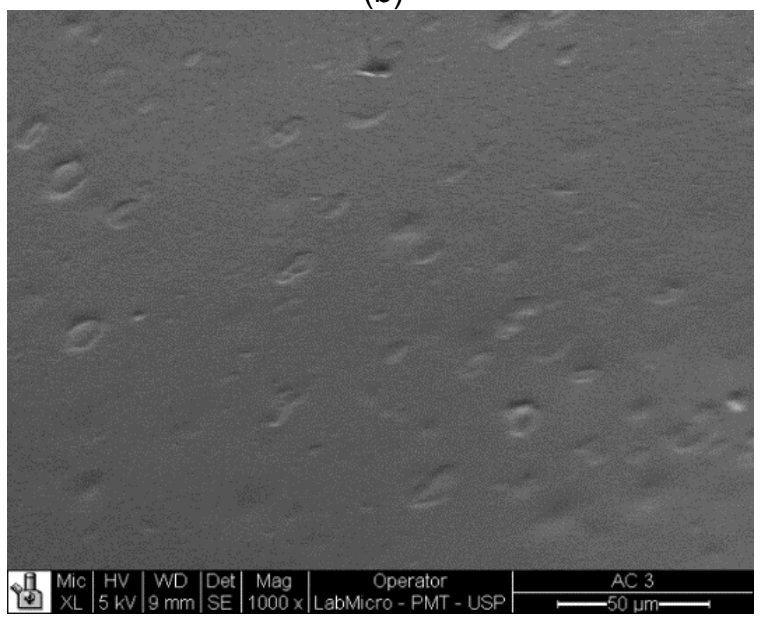

(d)

\subsubsection{Propriedades Mecânicas: Ensaio de Tração}

A Tabela 11 mostra as propriedades mecânicas das amostras nas direções x e y. Pode-se notar que não houve diferenças significativas no módulo de elasticidade, na resistência à tração e no alongamento, nas duas direções de calandragem.

Comparando as amostras 7 e $7 \mathrm{mod}$, que possuem temperaturas de processamento diferentes, nota-se que devido a temperatura mais baixa, a amostra 7 apresentou maiores valores de resistência à tração e menor alongamento, mostrando que a ductilidade do material aumenta com o aumento da temperatura.

Ao observar as amostras 7mod e AC3, verifica-se o efeito da quantidade de ácido. Quanto menor o percentual de ácido, obtém-se maiores valores de módulo elástico e resistência à tração, no entanto o alongamento total diminui um pouco. 
Finalmente, comparando o efeito da umidade, nas amostras AC2 e AC3, observa-se que a variação nas propriedades mecânicas não é significativa.

Tabela 11 - Propriedades mecânicas das amostras 7 e 7mod, AC2 e AC3 na direção de calandragem (y) e na direção perpendicular à de calandragem $(x)$.

\begin{tabular}{ccccc}
\hline & & $\begin{array}{c}\text { Módulo de } \\
\text { elasticidade } \\
(\mathbf{M P a})\end{array}$ & $\begin{array}{c}\text { Resistência à } \\
\text { Tração }(\mathbf{M P a})\end{array}$ & $\begin{array}{c}\text { Alongamento na } \\
\text { ruptura (\%) }\end{array}$ \\
\hline 7 & $\mathbf{X}$ & $17 \pm 1$ & $1,51 \pm 0,06$ & $30 \pm 2$ \\
& $\mathbf{Y}$ & $16 \pm 2$ & $1,30 \pm 0,02$ & $25 \pm 3$ \\
$7 \mathrm{mod}$ & $\mathbf{X}$ & $16 \pm 2$ & $0,56 \pm 0,02$ & $200 \pm 17$ \\
& $\mathbf{Y}$ & $17 \pm 1$ & $0,69 \pm 0,03$ & $192 \pm 20$ \\
AC2 & $\mathbf{X}$ & $21 \pm 2$ & $0,75 \pm 0,05$ & $149 \pm 16$ \\
& $\mathbf{Y}$ & $23 \pm 2$ & $0,79 \pm 0,08$ & $151 \pm 18$ \\
$\mathrm{AC3}$ & $\mathbf{X}$ & $20 \pm 1$ & $0,87 \pm 0,04$ & $149 \pm 15$ \\
& $\mathbf{Y}$ & $22 \pm 2$ & $0,86 \pm 0,03$ & $150 \pm 13$ \\
\hline
\end{tabular}

\subsubsection{Grau de Substituição (GS) e Grau de Esterificação (GE)}

A Tabela 12 mostra os resultados calculados do Grau de Substituição (GS) e do Grau de Esterificação (GE), para analisar se a temperatura de processamento e a quantidade de ácido cítrico influenciam na quantidade efetiva de reações éster ocorridas. Comparando as amostras AC2 e AC3, que possuem $2 \%$ de ácido cítrico e $20 \%$ e $30 \%$ de umidade, respectivamente, pode-se notar que não existem grandes diferenças ao aumentar a quantidade de umidade, o mesmo ocorre ao aumentar a quantidade de ácido cítrico de 2 para 4\%, e ao mudar a temperatura de processamento.

Nenhuma das amostras possui grânulos de amido inteiros, indicando que todos os grânulos foram plastificados, comprovando o resultado obtido nas curvas de torque. Pode-se notar que a amostra $7 \mathrm{mod}$ possui uma estrutura mais lisa, evidenciando 0 
efeito da temperatura. Dentre as amostras AC2 e AC3, a amostra AC3 está mais homogênea, o que pode indicar uma melhor plastificação.

Tabela 12- Resultado do Grau de substituição e do Grau de Esterificação.

\begin{tabular}{ccc}
\hline & GS & GE \\
\hline AC2 & $0,185 \pm 0,004$ & $17,1 \pm 0,2$ \\
AC3 & $0,186 \pm 0,001$ & $17,1 \pm 0,2$ \\
$\mathbf{7}$ & $0,183 \pm 0,004$ & $17,0 \pm 0,3$ \\
7MOD & $0,189 \pm 0,005$ & $17,1 \pm 0,3$
\end{tabular}

Dessa forma, verifica-se que mesmo aumentando o teor de ácido GS e GE não se alteram, indicando que existe um teor máximo de ácido cítrico que reage.

O resultado obtido nas amostras 7,7mod, AC2 e AC3 são superiores ao resultado obtido por Shiu et al. [61] com $20 \%$ de ácido cítrico. Este observou um aumento de GS e GE ao aumentar o teor de ácido cítrico de 10 até $40 \%$ em massa.

Utilizando o método de adição de ácido cítrico no amido por solução, Ma et al. [59] obtiveram GS de 0,085 para o amido de ervilha (35\% de amilose) e 0,089 (32\% de amilose) para o amido de arroz.

Assim, fica claro que o método adotado conseguiu bons resultados em relação ao grau de substituição.

\subsubsection{Etapa III: Analisando o TPS utilizando outros Ácidos Carboxílicos}

De acordo com os ensaios feitos nas amostras 7,7mod, AC2 e AC3 foram feitas análises com outros ácidos carboxílicos, na concentração de $2 \%$ e condições de processamento igual as de $\mathrm{AC} 2$ e AC3, já que essas obtiveram os melhores resultados em propriedades mecânicas e térmicas. Foram utilizados os ácidos: adípico (AA), malico (AM) e tartárico (AT). Vale lembrar que estes ácidos ainda não foram estudados para verificar como influenciam nas propriedades do TPS como plastificantes. 
Para esclarecer um pouco melhor o efeito da umidade os novos ácidos foram processados com $20 \%$ e $30 \%$ de umidade. Já que a amostra com $20 \%$ de umidade (AC2) se mostrou um pouco superior, por estar mais homogênea e com o pico de gelatinização bem definido, é necessário verificar se isso ocorre para todos os ácidos.

\subsubsection{Curvas de Torque}

A Figura 44 mostra as curvas de torque em função do tempo para as amostras com os diferentes ácidos. Pode-se notar que as misturas com o ácido adípico, apesar de possuírem o pico de gelatinização, que indica que a amostra plastificou, apresentam, após o término do pico, aumento nos valores de torque, o que pode indicar perda de água.

Figura 44 - Curvas de Torque em função do tempo para as amostras com Ácido Adípico, Ácido Cítrico, Ácido Málico e Ácido Tartárico.
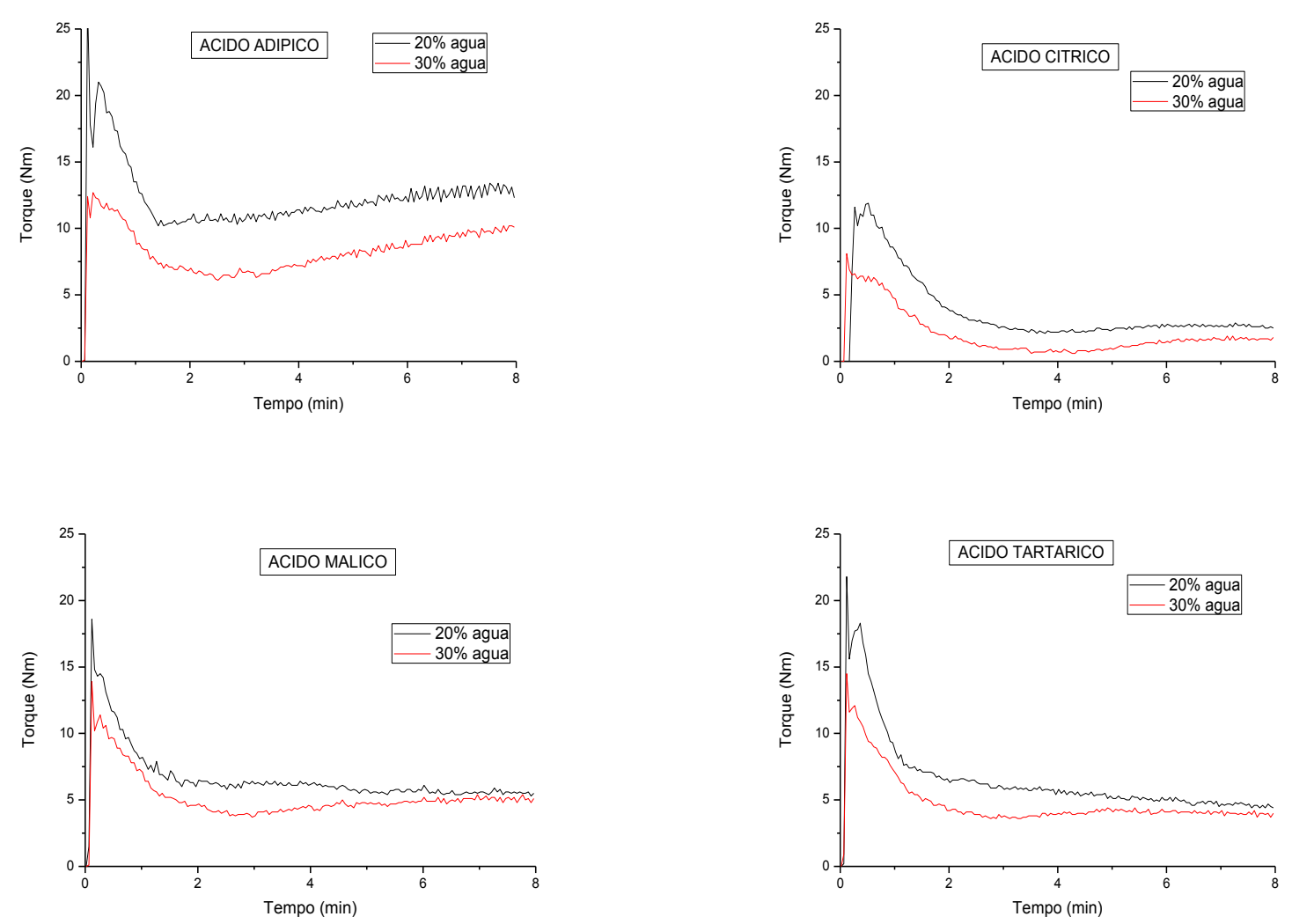
Os outros ácidos gelatinizaram, e as amostras com $20 \%$ de umidade apresentaram um torque final um pouco mais alto do que as com $30 \%$ de umidade, o que já era esperado, pois com mais água, as moléculas se movimentam com mais facilidade, influenciando o torque final.

\subsubsection{Espectroscopia Vibracional de Absorção no infravermelho com transformada de Fourier (FTIR)}

A Figura 45 mostra os espectros FTIR do TPS sem e com os diferentes ácidos. Observa-se que todas as amostras possuem um pico em $1650 \mathrm{~cm}^{-1}$ referente à ligação $\mathrm{C}=\mathrm{C}$. As amostras com ácido carboxílico possuem pico em $1730 \mathrm{~cm}^{-1}$ referente ao grupo éster. Nota-se ainda que o ácido cítrico possui o pico na região de $1700 \mathrm{~cm}^{-1}$ um pouco mais definido, isso pode ocorrer pois, além da reação de esterificação, o ácido cítrico ao ser aquecido forma um anidrido que reage com o amido por substituição nucleofílica acílica.

Figura 45 - Espectros FTIR das amostras de TPS com e sem os ácidos carboxílicos.

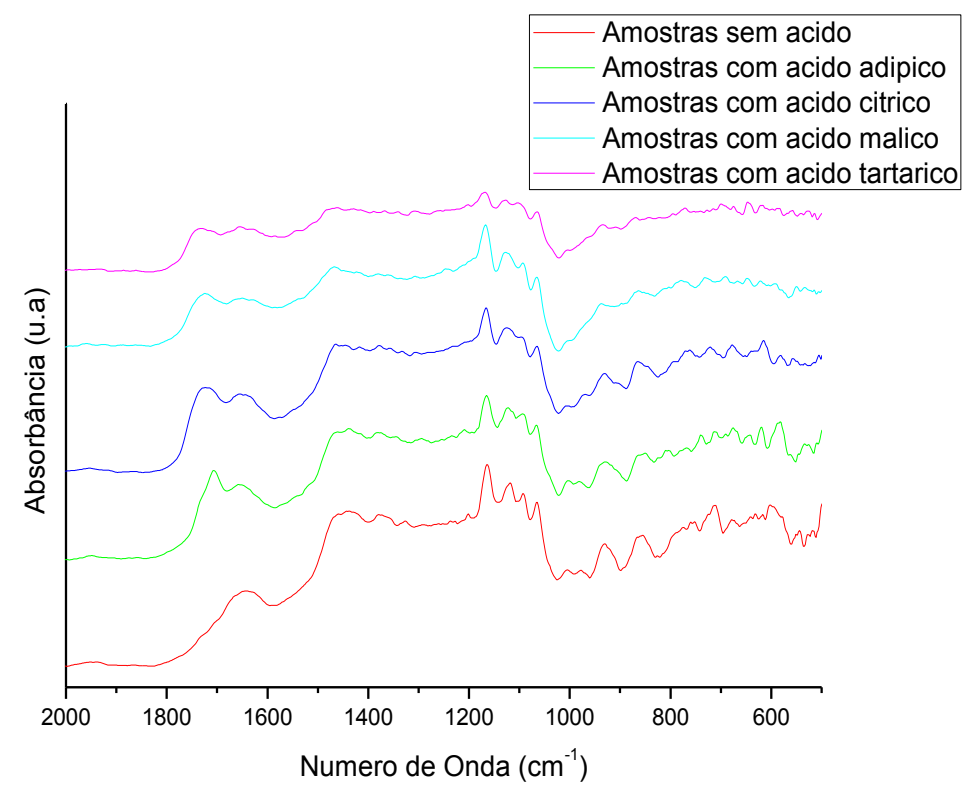

\subsubsection{Curvas termogravimétricas}

Primeiramente foi realizada a análise termogravimétrica para os ácidos puros, como mostra a Figura 46. As temperaturas de início de degradação para todos os 
ácidos são em torno de $150^{\circ} \mathrm{C}$. Os ácidos adípico, cítrico, málico e tartárico atingem $50 \%$ de perda de massa em $270,235,250$ e $245^{\circ} \mathrm{C}$, respectivamente.

Figura 46 - Análise termogravimétrica: (a) TG e (b) DTG dos ácidos carboxílicos.
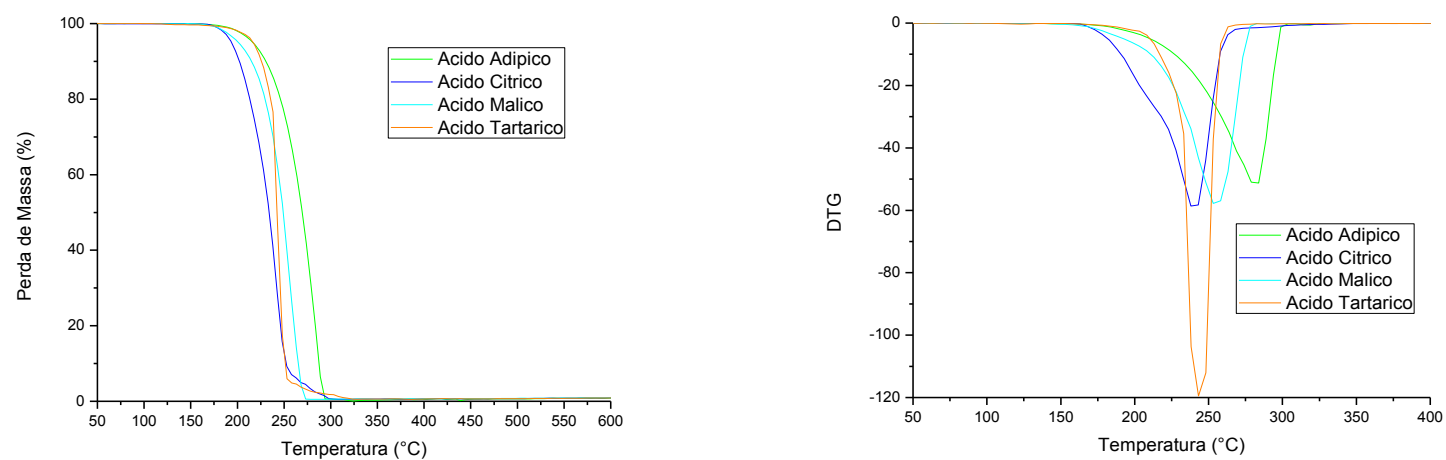

(a)

(b)

Logo após foram analisadas todas as amostras de TPS com teores de água de 20 e $30 \%$ em massa, como mostra a Figura 47. Analisando as curvas de todas as amostras, não houve diferença significativa na curva DTG em função do teor de água.

Figura 47 - Curvas DTG para as amostras de TPS sem ácido (a), com ácido adípico (b), com ácido cítrico(c), com ácido málico (d) e com ácido tartárico (e).

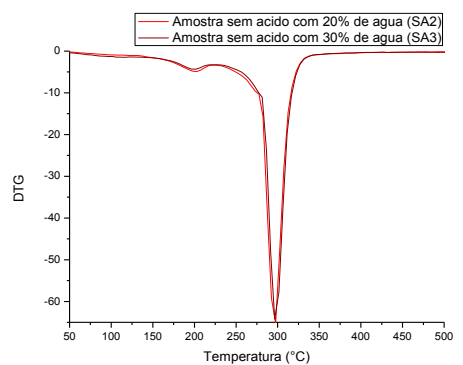

(a)

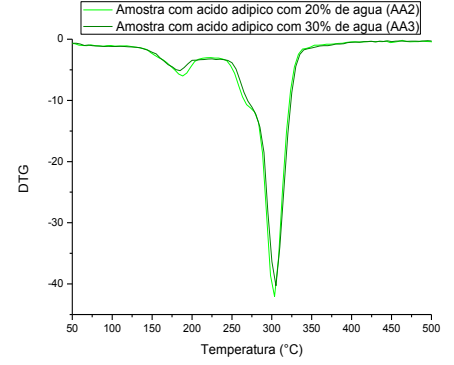

(b)

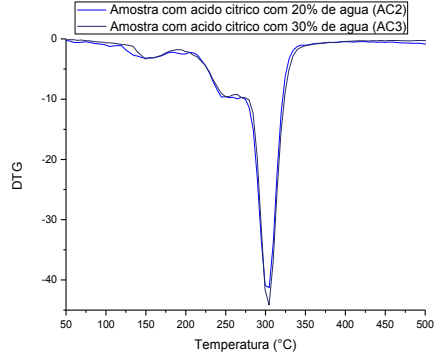

(c)

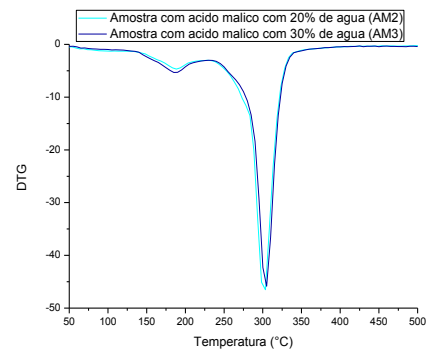

(d)

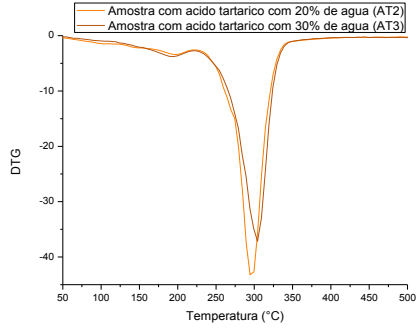

(e) 
Para ser realizada uma comparação das temperaturas de degradação do TPS sem e com cada ácido carboxílico, escolheu-se as amostras com $20 \%$ em massa de água. A Figura 48 apresenta a curva DTG para o amido de milho (a) e para os diferentes TPS (b). Pode-se notar que o amido de milho possui apenas um estágio de degradação, que se refere apenas ao amido; a amostra sem ácido possui dois estágios: referente ao glicerol e ao amido; e as amostras com os ácidos possuem três estágios: referente ao glicerol, aos próprios ácidos e ao amido. A Tabela 13 mostra as temperaturas de início da degradação do amido e dos TPS. A temperatura de degradação para o amido puro é $285^{\circ} \mathrm{C}$, para todos os TPS o início da temperatura de degradação do amido é menor, sendo que a maior queda ocorre para a amostra sem ácido $\left(235^{\circ} \mathrm{C}\right)$.

Figura 48 - Curvas DTG para o amido (a) e para as amostras de TPS (b).

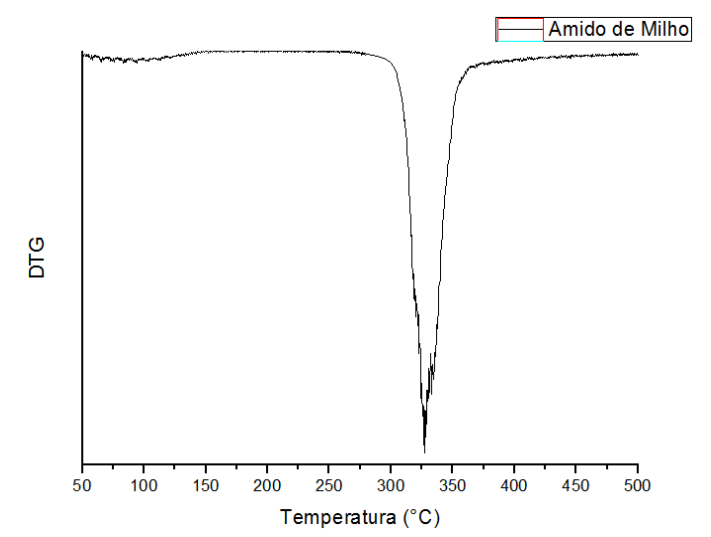

(a)

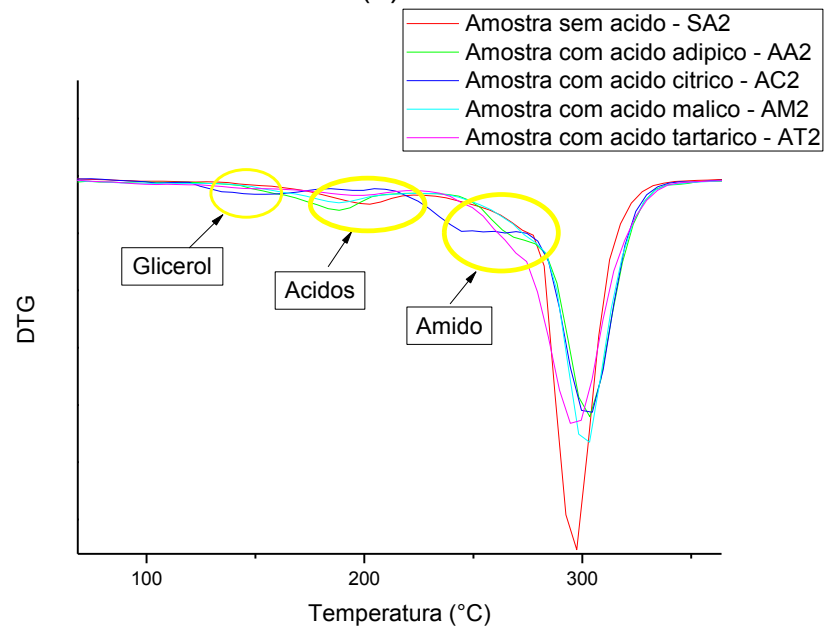

(b) 
Tabela 13 - Temperaturas de início da degradação do amido e dos TPS.

\begin{tabular}{|c|ccc|}
\hline & \multicolumn{3}{|c}{ Temperaturas de início da } \\
degradação \\
\hline Amostra & $\begin{array}{c}\text { Glicerol } \\
\left({ }^{\circ} \mathrm{C}\right)\end{array}$ & $\begin{array}{c}\text { Ácido } \\
\text { Carboxílico } \\
\left({ }^{\circ} \mathrm{C}\right)\end{array}$ & $\begin{array}{c}\text { Amido } \\
\left({ }^{\circ} \mathrm{C}\right)\end{array}$ \\
\hline $\begin{array}{c}\text { Amido de Milho } \\
\text { TPS sem ácido } \\
\text { (SA2) }\end{array}$ & - & - & 285 \\
\hline $\begin{array}{c}\text { TPS com ácido } \\
\text { adípico (AA2) }\end{array}$ & 135 & - & 235 \\
\hline $\begin{array}{c}\text { TPS com ácido cítrico } \\
\text { (AC2) }\end{array}$ & 120 & 235 & 275 \\
\hline $\begin{array}{c}\text { TPS com ácido málico } \\
\text { (AM2) }\end{array}$ & 135 & 230 & 270 \\
\hline $\begin{array}{c}\text { TPS com ácido } \\
\text { tartárico (AT2) }\end{array}$ & 135 & 230 & 275 \\
\hline
\end{tabular}

Em relação à primeira perda de massa relativa ao glicerol, os que possuem menor temperatura são o ácido adípico e o ácido cítrico. $O$ ácido adípico, por possuir uma cadeia mais longa e não possuir grupos hidroxila, é mais fácil de liberar o glicerol pela quebra da ligação. Já o ácido cítrico, devido a sua estereoquímica, ao ser aquecido durante o processamento, pode formar um anidrido, que reage com o amido e com o glicerol por substituição nucleofílica acílica.

Ao analisar a segunda perda de massa, referente aos ácidos carboxílicos, pode-se observar que o ácido cítrico possui a menor temperatura de início de degradação. Isso pode ocorrer, novamente, devido a sua estereoquímica e porque o ácido carboxílico do terceiro carbono possui uma ligação mais fraca.

Ao analisar a terceira perda de massa, verifica-se que para todos os TPS a temperatura de início de degradação é menor do que para o amido puro, sendo menor para o TPS sem ácido. Isso pode ocorrer pois ao adicionar o glicerol, as cadeias ficam mais espaçadas, tornando a ligação mais fraca.

Entretanto, ao adicionar os ácidos a temperatura aumenta em relação ao TPS sem ácido. Provavelmente ao adicionar os ácidos carboxílicos têm-se ligações mais fortes do que apenas as de glicerol e amido. 


\subsubsection{Calorimetria Exploratória Diferencial (DSC)}

A Tabela 14 mostra o resultado das análises obtidas por DSC. Analisando a sub- $T_{g}$ verifica-se que as amostras com ácido adípico apresentam valores um pouco maiores do que as demais. Isto ocorre, provavelmente, porque a molécula de ácido adípico não apresenta grupos hidroxilas e, portanto, as ligações de hidrogênio nesta amostra só irão ocorrer entre as moléculas de glicerol e amido.

A amostra com ácido cítrico mostrou o menor valor de $T_{g}$, isso pode ocorrer porque o ácido carboxílico do terceiro carbono, por ser um grupo lateral volumoso, pode enfraquecer as ligações intermoleculares. Para os demais as temperaturas, os valores são próximos.

Tabela 14 - Análise das curvas de DSC.

\begin{tabular}{c|ccc}
\hline Amostra & $\begin{array}{c}\text { Sub-Tg } \\
\left({ }^{\circ} \mathrm{C}\right)\end{array}$ & $\operatorname{Tg}\left({ }^{\circ} \mathrm{C}\right)$ & $\operatorname{Tm}\left({ }^{\circ} \mathrm{C}\right)$ \\
\hline SA2 & -84 & 55 & 134 \\
SA3 & -83 & 55 & 85 \\
\hline$A C 2$ & -88 & 34 & 92 \\
$A C 3$ & -86 & 45 & 87 \\
\hline$A M 2$ & -85 & 48 & 100 \\
$A M 3$ & -86 & 47 & 96 \\
\hline$A T 2$ & -85 & 51 & 96 \\
\hline$A T 3$ & -84 & 50 & 101 \\
\hline AA2 & -70 & 48 & 94 \\
AA3 & -78 & 55 & 103 \\
\hline
\end{tabular}

Nas amostras com ácido adípico, ao aumentar o teor de água a sub $T_{g}$ diminui, isso pode ocorrer, pois ao adicionar água, ocorre um aumento da mobilidade da cadeia, além de ser possível ter mais ligações de hidrogênio no amido e no glicerol com a água, diminuindo as interações entre amido e glicerol. 
Para as amostras sem ácido e com os ácidos málico e tartárico a $T_{g}$ praticamente não se altera com o teor de umidade. Os reagentes possuem hidroxilas que tornam o material mais estável devido às ligações de hidrogênio.

Nas amostras sem ácido, ao adicionar mais água, os valores de $T_{m}$ diminuem, provavelmente, porque ao adicionar água, ocorre um aumento da mobilidade da mobilidade da cadeia.

\subsubsection{Difração de Raios X (DRX)}

A Figura 49 mostra as curvas obtidas nas análises de DRX para as amostras sem ácido cítrico (SA), com ácido adípico (AA), ácido cítrico ( $A C)$, ácido málico (AM) e ácido tartárico (AT) com $20 \%$ e com $30 \%$ em peso de água.

Para todas as amostras foram encontrados 6 picos referentes aos cristais $\mathrm{V}_{\mathrm{H}}$, 2 picos referentes aos cristais $V_{A}$ e apenas um pico referente ao cristal $\mathrm{E}_{\mathrm{H}}$.

Pode-se observar que em todas as amostras, ao mudar o teor de água, não houve mudança no tipo de cristal formado, ocorreram apenas pequenas mudanças de posição e definição em alguns picos.

Para as amostras sem ácido, verifica-se que ao diminuir o teor de água os picos referentes ao cristal $V_{A}$ ficam mais definidos. $O$ padrão $V_{A}$ possui hélices de amilose mais contraídas e com menos água do que a rede $\mathrm{V}_{\mathrm{H}}$, logo, sem a presença do ácido, quanto menor o teor de água mais definido o pico. Com o ácido adípico ocorre o oposto, com maior teor de água o pico é mais definido.

Nas amostras com ácido cítrico verifica-se que a amostra com maior teor de água possui o pico $\mathrm{E}_{H}$ mais definido e nota-se uma pequena variação na posição dos picos relacionados ao cristal $\mathrm{V}_{\mathrm{A}}$. Para as amostras com ácido málico e ácido tartárico não foi visto nenhuma alteração significativa. 
Figura 49 - Curvas de DRX das amostras com 20 e $30 \%$ de água, sem ácido carboxílico (a) e com os ácidos carboxílicos: adípico (b), cítrico (c), málico(d) e tartárico(e).

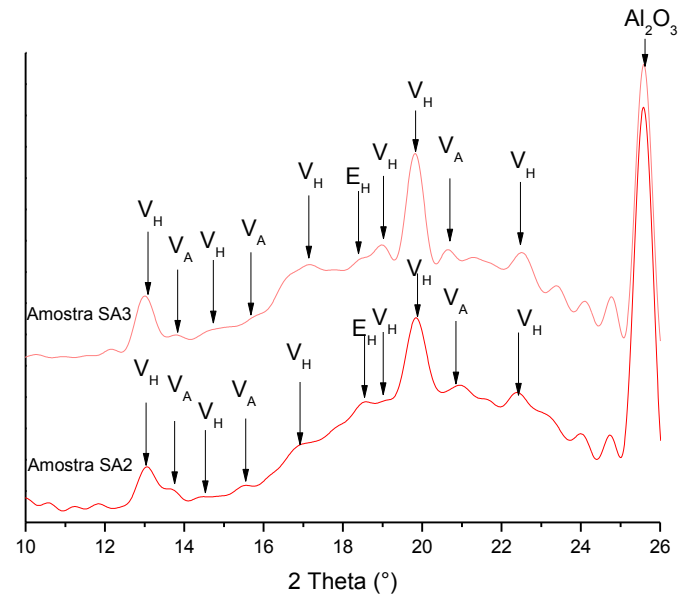

(a)

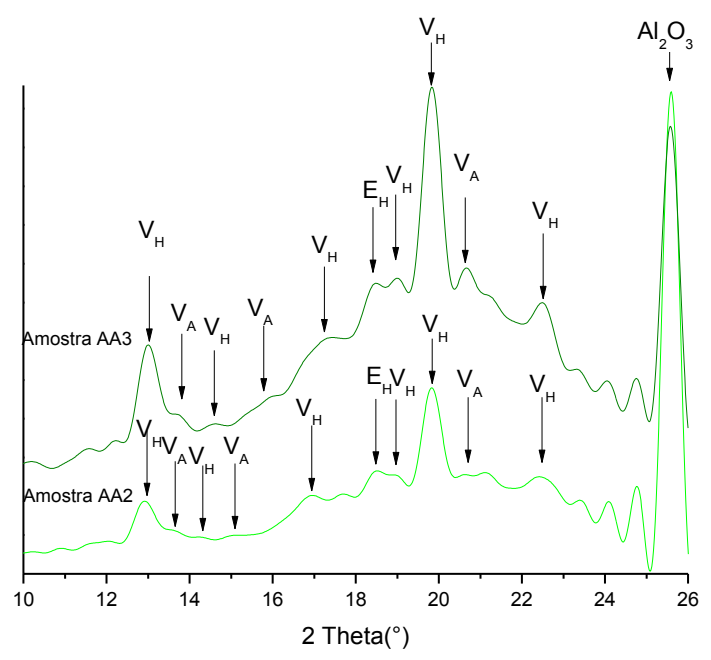

(b)

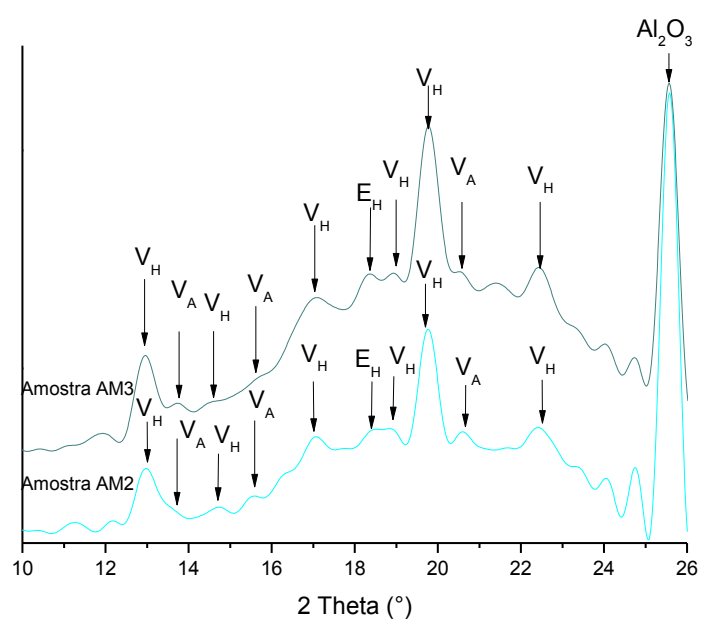

(d)

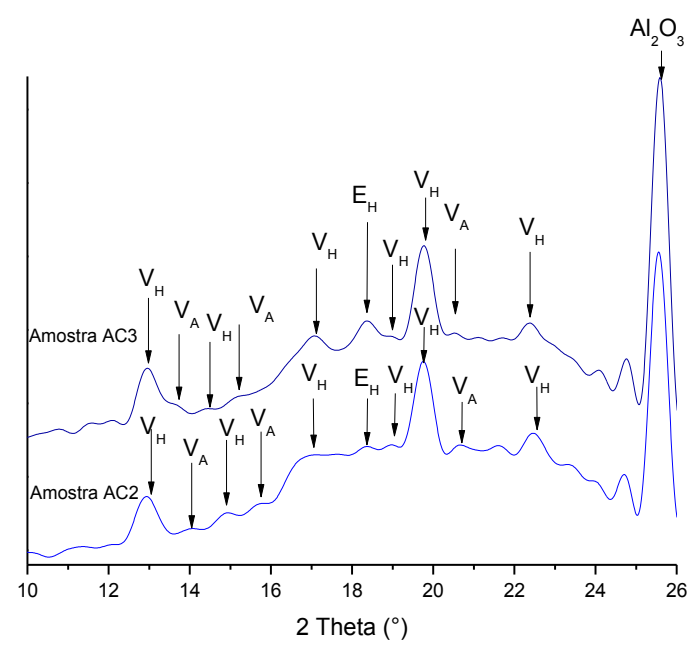

(c)

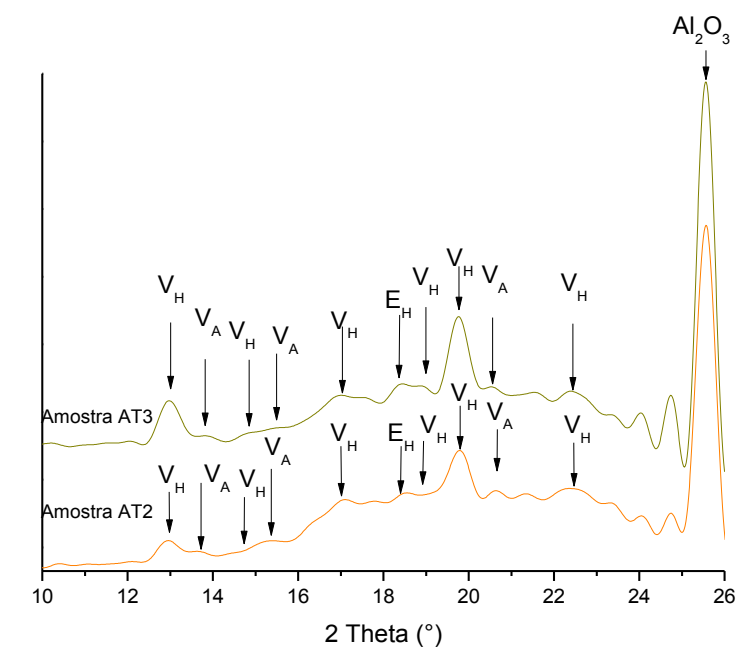

(e) 
Vale lembrar que os cristais do tipo $\mathrm{V}_{\mathrm{A}}$ e $\mathrm{E}_{\mathrm{H}}$ são cristais instáveis com estruturas helicoidais típicas dos complexos formados entre a amilose e os lípidos presentes no amido.

A Tabela 15 mostra os valores dos picos encontrados em cada amostra e os picos de referência. Pode-se verificar que as amostras sem ácido, com ácido adípico e com ácido cítrico possuem um maior desvio no deslocamento do pico, para todas as estruturas com picos inferiores a $2 \theta=20^{\circ}$.

Tabela 15 - Picos das curvas de DRX para todas as amostras.

\begin{tabular}{|c|c|c|c|c|c|c|}
\hline $\begin{array}{l}\text { Tipo } \\
\text { de }\end{array}$ & SA2 SA3 & AA2 AA3 & AC2 AC3 & AM2 AM3 & AT2 AT3 & $\begin{array}{l}\text { Picos de } \\
\text { Referência } \\
\text { (Literatura) }\end{array}$ \\
\hline Cristal & 2 theta $\left({ }^{\circ}\right)$ & 2 theta $\left({ }^{\circ}\right)$ & 2 theta $\left({ }^{\circ}\right)$ & 2 theta $\left({ }^{\circ}\right)$ & 2 theta $\left(^{\circ}\right)$ & $\begin{array}{c}2 \text { theta } \\
\left({ }^{\circ}\right)\end{array}$ \\
\hline$V_{H}$ & 13 & 13 & 13 & 13 & 12,9 & 13 \\
\hline$V_{A}$ & 13,7 & 13,8 & 13,7 & 13,7 & 14 & 13,6 \\
\hline$V_{H}$ & 14,8 & 14,8 & 14,8 & 14,9 & 14,9 & 14,9 \\
\hline$V_{A}$ & 15,5 & 15,7 & 15,7 & 15,9 & 15,8 & 15,8 \\
\hline $\mathrm{V}_{\mathrm{H}}$ & 17 & 17,1 & 17 & 17,1 & 16,9 & 17 \\
\hline $\mathrm{E}_{\mathrm{H}}$ & 17,8 & 18,4 & 18,5 & 18,4 & 18,37 & 18,4 \\
\hline $\mathrm{V}_{\mathrm{H}}$ & 18,6 & 18,8 & 18,8 & 18,9 & 18,9 & 18,8 \\
\hline$V_{H}$ & 19,4 & 19,4 & 19,4 & 19,4 & 19,4 & 19,4 \\
\hline$V_{A}$ & 20,9 & 20,7 & 20,7 & 20,7 & 20,7 & 20,8 \\
\hline$V_{H}$ & 22,5 & 22,5 & 22,5 & 22,5 & 22,5 & 22,6 \\
\hline
\end{tabular}

\subsubsection{Microscopia Eletrônica de Varredura (MEV)}

Para verificar a homogeneidade das misturas foi realizada MEV. Os resultados estão na Figura 50. Pode-se notar que as amostras com 30\% de água estão mais homogêneas, e em nenhuma delas nota-se grânulos de amido. 
Figura 50 - MEV das amostras com $2 \%$ de diferentes ácidos e concentrações de água: TPS com ácido adípico com $20 \%$ de água (a), TPS com ácido adípico com $30 \%$ de água (b), TPS com ácido málico com $20 \%$ de água (c), TPS com ácido málico com $30 \%$ de água (d), TPS com ácido tartárico com $20 \%$ de água (e), TPS com ácido tartárico com $30 \%$ de água (f),

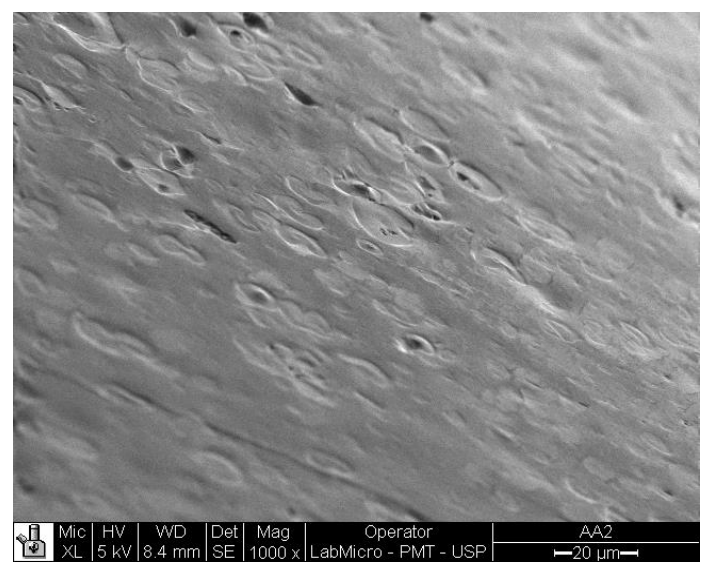

(a)

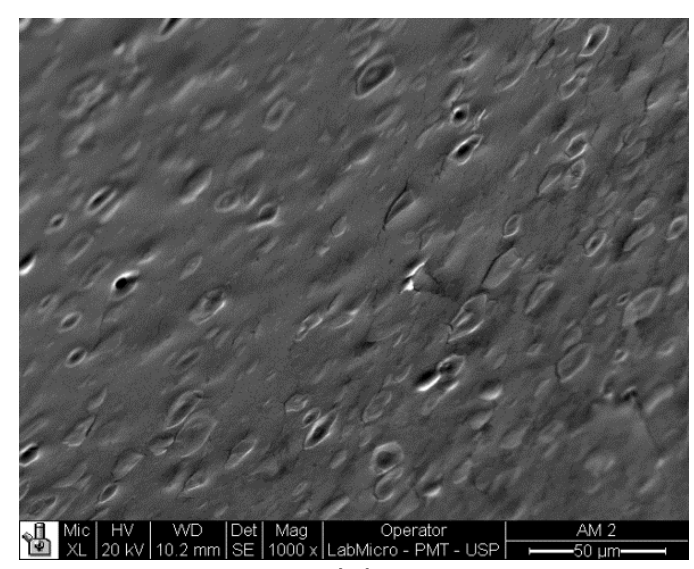

(c)

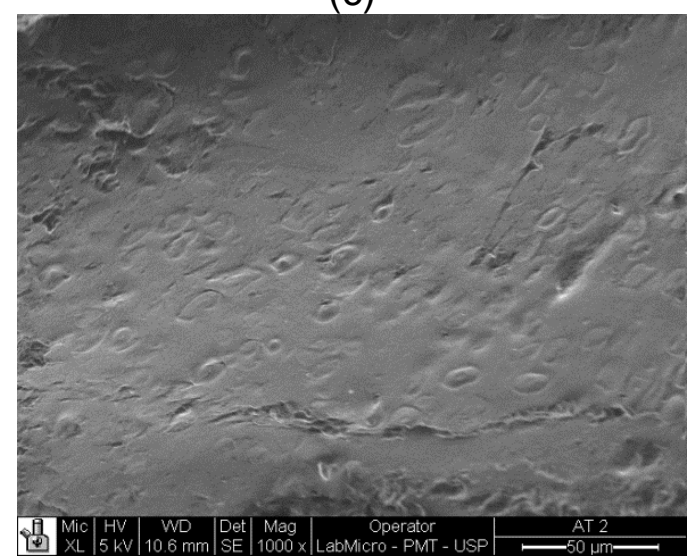

(e)

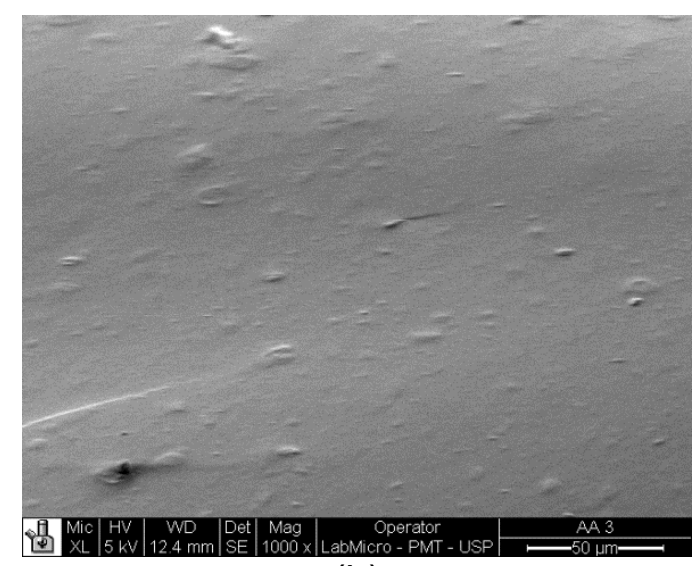

(b)

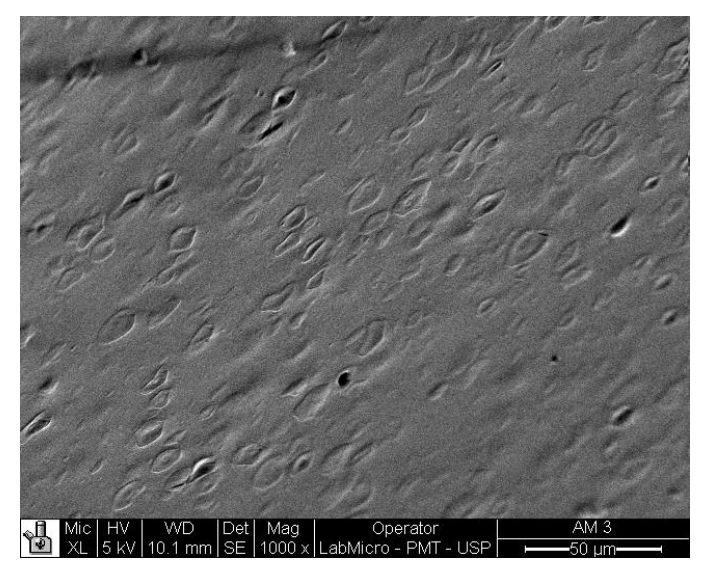

(d)

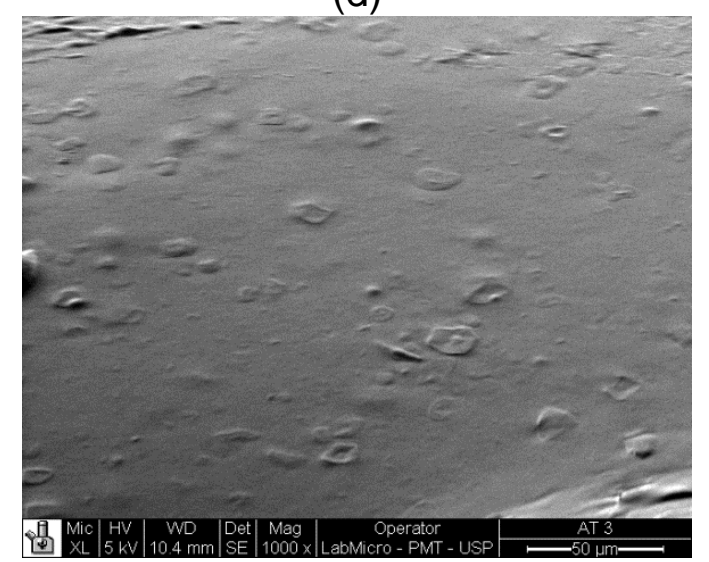

(f) 


\subsubsection{Propriedades Mecânicas: Ensaio de Tração}

A Figura 51 mostra os gráficos do Módulo de elasticidade (a), Resistência à tração (b) e alongamento na ruptura (c) obtidos no ensaio de tração, para as amostras de TPS sem o ácido carboxílico e com $2 \%$ em massa dos ácidos carboxílicos, nas duas direções de calandragem, $x$ e $y$.

Para todas as amostras não houve diferença significativa entre as direções $x \mathrm{e}$ y. A amostra com ácido cítrico possui os menores valores de módulo de elasticidade e resistência à tração, e possui maior alongamento. Este resultado corrobora com o DSC das amostras, já que as amostras com ácido cítrico possuem valores de $T_{g}$ mais baixos.

As amostras sem ácido possuem o segundo menor valor de módulo de elasticidade e um baixo valor de alongamento, quando comparado com as demais.

As amostras com ácido adípico possuem maior desvio padrão. Provavelmente isto se deve ao aumento do torque observado durante o processamento, onde houve perda de água.

Figura 51 - Propriedades mecânicas das amostras de TPS sem e com $2 \%$ de ácidos carboxílicos (adipico, cítrico, málico e tartárico) obtidas no ensaio de Tração nas direções x e y de calandragem: Módulo de elasticidade (a), Resistência à tração (b) e Alongamento na ruptura (c).

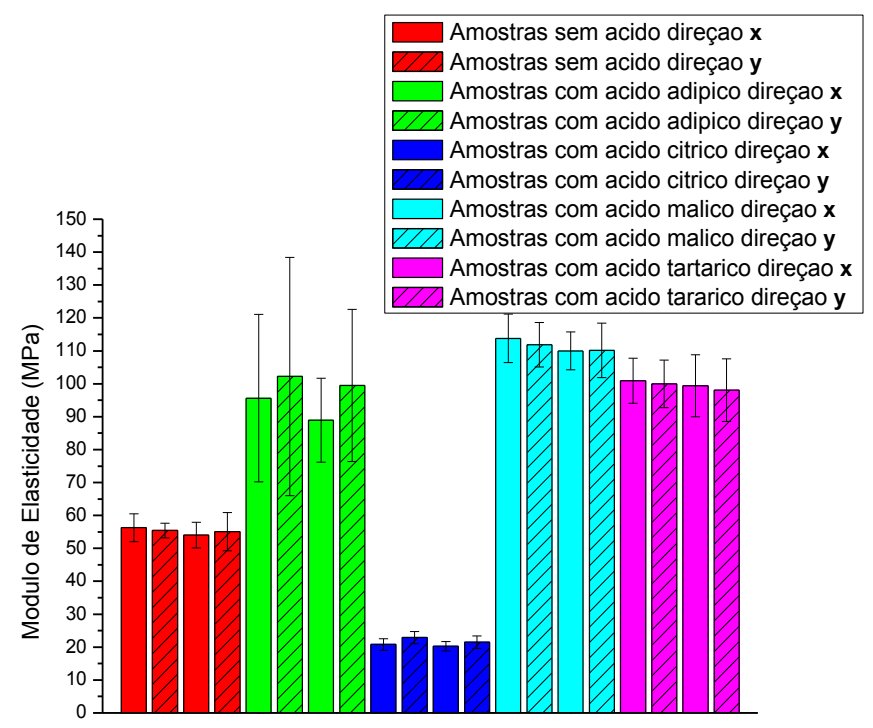

(a) 


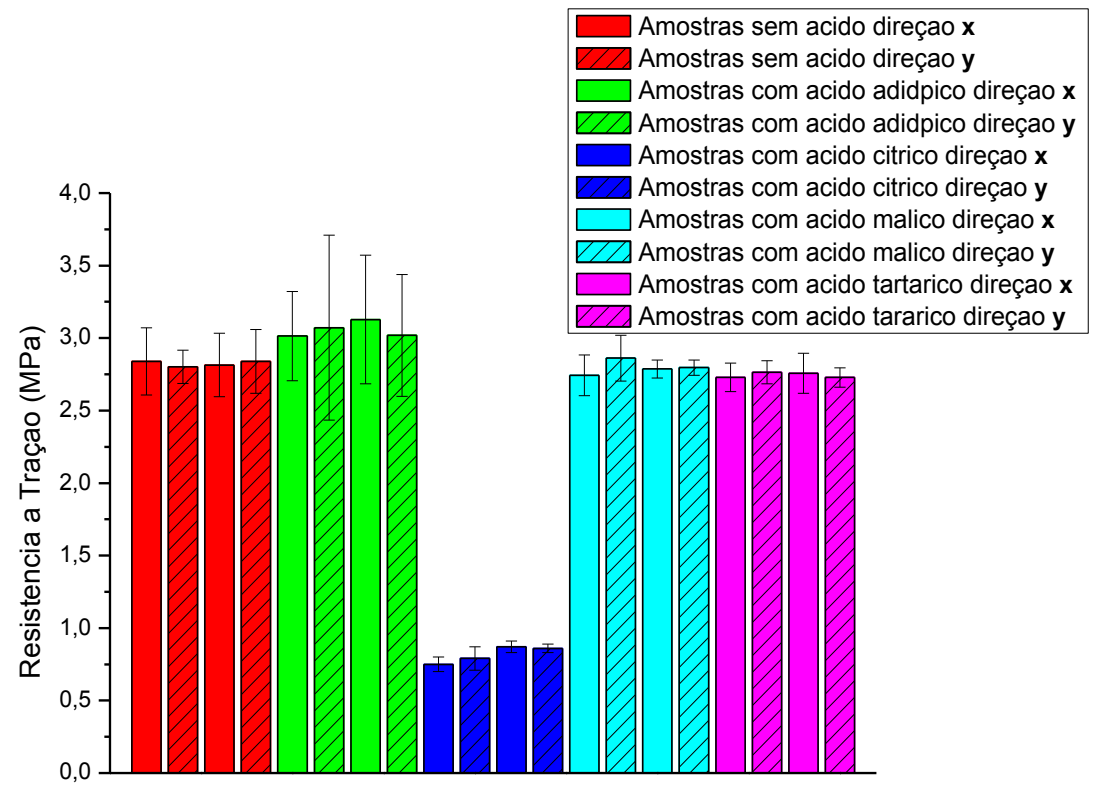

(b)

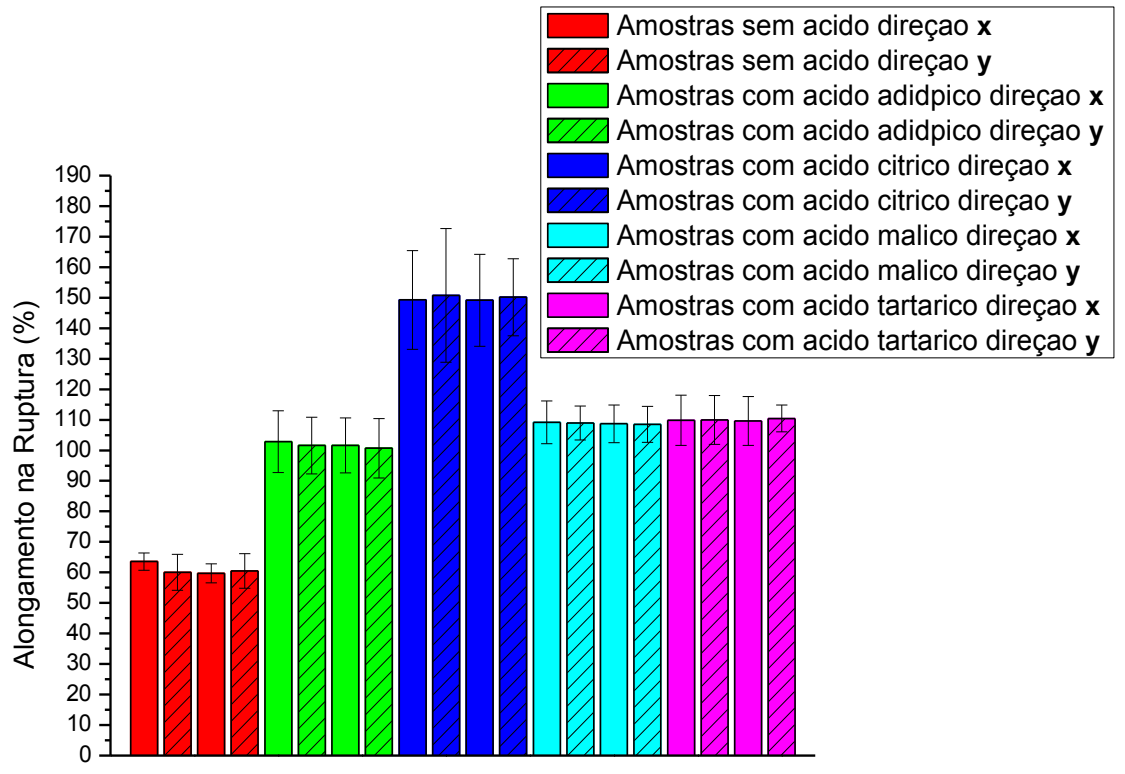

(c) 


\subsection{CONCLUSÕES DO CAPÍTULO}

Neste capítulo foi realizado o estudo do TPS de amido de milho com a composição de $30 \%$ em massa de glicerol, 20 e 30\% em massa de água e os ácidos carboxílicos: adípico, cítrico, málico e tartárico. Na parte experimental, primeiramente foi realizado um planejamento estatístico para otimizar a composição e a condição de processamento do TPS, variando o teor de água e ácido cítrico, e a temperatura a ser utilizada. Para um estudo um pouco mais aprofundado do efeito do teor de ácido (2 ou $4 \%$ em massa), teor de água (20 ou $30 \%$ em massa) e temperatura de processamento foram preparadas 4 amostras e analisou-se as propriedades mecânicas, a morfologia, propriedades térmicas e as ligações químicas formadas. De acordo com os resultados, foi escolhida a temperatura de processamento de $125^{\circ} \mathrm{C} \mathrm{e}$ teor de ácido de $2 \%$ em massa para estudar o efeito de cada ácido carboxílico no TPS. As seguintes observações podem ser feitas a partir dos resultados apresentados neste capítulo:

- O planejamento estatístico mostrou que todas as amostras processadas no reômetro de torque mostraram um pico de gelatinização, indicando que todas as amostras plastificaram. Este resultado pôde ser confirmado por microscopia;

- As amostras sem ácido e com ácido adípico tendem a apresentar aumento nos valores de torque, após o pico de gelatinização, o que pode estar relacionado com a perda de água;

- O teor de ácido escolhido foi de $2 \%$ pois a presença de maior teor de ácido torna a mistura pegajosa, com baixa temperatura de degradação térmica; e, com menores teores de ácido o processamento é muito difícil e ocorre um aumento nos valores de torque após o pico de gelatinização;

- Ao aumentar o teor de água ocorre uma queda no valor da $T_{g}$, pois, ao aumentar o teor de água tem-se maior mobilidade das moléculas;

- Podem ser observados três tipos de cristais no TPS: $V_{H}, V_{A}$ e EH. Mas predominam as estruturas $\mathrm{V}_{\mathrm{H}}$, que são mais estáveis;

- A ductilidade do material aumenta com o aumento da temperatura de processamento; 
- Quanto menor o percentual de ácido no TPS, maiores os valores de módulo de elasticidade e resistência à tração. No entanto, há uma pequena redução nos valores de alongamento na ruptura;

- No TPS com os ácidos carboxílicos ocorrem três perdas de massa: a primeira relativa ao glicerol, a segunda relativa ao próprio ácido carboxílico e a terceira referente ao amido.

- Comparando o ácido cítrico com os demais ácidos, a temperatura em que se inicia as três perdas de massa são menores. Isso ocorre devido a estereoquímica do ácido e da ligação do terceiro carbono ser mais fraca. Além disso, ao ser aquecido durante o processamento, pode-se formar um anidrido, o qual pode reagir com o amido e com o glicerol por substituição nucleofílica acílica.

- O TPS com ácido cítrico possui menores valores de $T_{g}$, de módulo de elasticidade e de resistência à tração, e maiores valores de alongamento, quando comparado com os TPS com adição de outros ácidos carboxílicos.

- As amostras com $2 \%$ em massa de ácido málico e ácido tartárico mostraram melhores propriedades térmicas e mecânicas, além de uma melhora na processabilidade e homogeneidade das amostras, quando comparadas com o TPS sem ácido e com os ácidos: cítrico e adípico. 


\section{CAPÍTULO 4: ENVELHECIMENTO DO TPS}

\subsection{INTRODUÇÃO}

Neste Capítulo será discutido o envelhecimento do amido e do TPS em condições de estocagem. Embora existam vários produtos à base de amido já disponíveis no mercado global, plásticos à base de amido têm algumas desvantagens que limitam sua aplicação, incluindo a limitada estabilidade a longo prazo, causada pela absorção de água, o envelhecimento pós-processamento e propriedades mecânicas inferiores as dos plásticos convencionais, como os commodities. Nas últimas décadas, diferentes abordagens têm sido utilizadas para vencer estas limitações e elevar o número de sectores em que plásticos à base de amido podem ser usados. Por conseguinte, inúmeros estudos têm sido realizados para desenvolver um plástico à base de amido completamente biodegradável, com propriedades mecânicas semelhantes aos polímeros convencionais, que não são afetados pela umidade e envelhecimento pós-processamento

\subsection{REVISÃO BIBLIOGRÁFICA}

Após o processamento o TPS não está em equilíbrio, logo sua estrutura e suas propriedades macroscópicas são dependentes do tempo [125] [126] [127] [128]. Estas mudanças são um dos principais limites para a aprovação do TPS em aplicações comerciais [129].

Durante o envelhecimento o TPS pode apresenta diferentes comportamentos, dependendo do teor de água e da temperatura de transição vítrea [110]:

- Nos materiais com média a alta umidade (temperatura ambiente acima da Tg) ocorre separação das fases, plastificante e amido, e cristalização das cadeias de amido (retrogradação)[115];

- Os materiais com baixo teor de umidade, ou seja, com teor de água inferior a $30 \%$ da massa total seca (domínio sub-Tg), apresenta envelhecimento físico ou relaxamento estrutural [130][131]. 
Os materiais vítreos exibem propriedades mecânicas e físicas semelhantes às dos sólidos cristalinos, entretanto, possuem um arranjo molecular mais característico de um líquido, estando fora do seu equilíbrio termodinâmico. Logo, ao serem armazenados a uma temperatura abaixo da sua temperatura de transição vítrea estão sujeitas a rearranjos moleculares, levando a menores estados de energia. Assim, o envelhecimento físico pode ser considerado um rearranjo molecular (relaxação estrutural) para um equilíbrio, em função do tempo de armazenamento e da temperatura [132] [133].

\subsubsection{Cristalinidade}

Para materiais de amido, à temperatura ambiente acima da $T_{g}, \quad 0$ envelhecimento ocorre principalmente devido à formação de estrutura intermolecular dupla hélice e cristalinidade tipo B: o processo de retrogradação. Como a retrogradação é lenta na amilopectina, a sua cristalização tem um papel importante no envelhecimento do TPS [134][135][125]. No entanto, a cristalização da amilose também contribui para as alterações nas propriedades dependentes do tempo, especialmente quando um alto teor de plastificantes é utilizado [136]. Os cristais do tipo $V$, que são formados no período inicial de armazenamento, também contribuem para a alteração das propriedades mecânicas durante o envelhecimento e atuam como pontos de ligação cruzada no material.

As propriedades mecânicas dos materiais de amido de milho são fortemente influenciadas pela retrogradação. Semelhante aos polímeros sintéticos, um aumento na quantidade de cristalinidade do tipo B resulta em aumento do módulo de elasticidade e dureza do material [134] [115]. A cristalinidade intermolecular devido a formação de ligações cruzadas, reforça a rede. A cristalização intramolecular da amilopectina, diminui a mobilidade da amilopectina e aumenta a tensão em zonas de junção altamente cristalinas. Ao mesmo tempo, o alongamento entre os pontos é de junção é limitado, o que resulta na queda dos valores do alongamento na ruptura. Em regiões cristalinas, o TPS pode quebrar espontaneamente como resultado da tensão interna e rachaduras geradas por cristais [137] . 
A alteração das propriedades é causada pela re-cristalização da amilopectina ou cristalização da amilose para para novos cristais do tipo V. A retrogradação provoca a fragilização do TPS e muitas vezes, torna o material mais opaco. A retrogradação geralmente é mais rápida em amidos ricos em amilose, uma vez que as cadeias lineares possuem maior mobilidade para formar única hélice de cristais do tipo V. A re-cristalização da amilopectina ocorre através da firmação de duplas hélices por entrelaçamento das ramificações de cadeias adjacentes [129].

\subsubsection{Temperatura de transição vítrea}

Sólidos amorfos não estão em equilíbrio termodinâmico em temperaturas abaixo de sua transição vítrea $(\mathrm{Tg})$. Tais materiais devem ser considerados como líquidos super-resfriados, cujos valores de volume, entalpia e entropia são maiores do que seriam obtidos no estado de equilíbrio [138], como mostra a Figura 52.

Figura 52 - Origem do envelhecimento. $T_{g}$ representa a temperatura de transição vítrea, sub- $T_{g}$ a temperatura de transição secundária mais baixa, e v o volume específico.

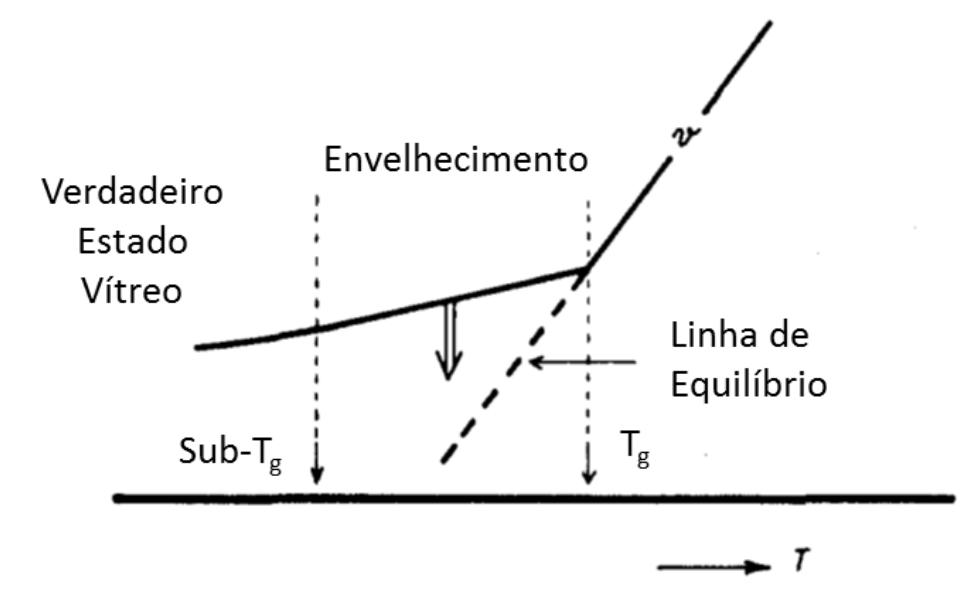

Fonte: Adaptado de [138]

Estudos sobre o relaxamento de materiais vítreos revelaram que eles passam por processos lentos que tentam estabelecer o equilíbrio termodinâmico, o que indica que, mesmo abaixo da $T_{g}$ a mobilidade molecular não é exatamente zero. A tentativa gradual de atingir o equilíbrio afeta muitas propriedades do material. Estas 
propriedades mudam com o tempo, e o material é submetido ao envelhecimento, ou "envelhecimento físico" [138].

Envelhecimento físico é uma continuação gradual da formação que se ajusta em torno da $T_{g}$ (Figura 52). Por isso afeta todas as propriedades dependentes da temperatura que mudam drasticamente e abruptamente na $T_{g}$. Durante o envelhecimento as propriedades se alteram, o material torna-se mais duro e mais frágil, modificando: fluência, relaxação de tensão, constante dielétrica, perdas dielétricas, etc [139].

Assim, durante o armazenamento, ocorre um relaxamento das moléculas do TPS, onde as moléculas se rearranjam em um estado de menor energia, o que afeta a entalpia, o volume, a difusão e as propriedades mecânicas [140]. Analisando as curvas endodérmicas do DSC, a entalpia de relaxação é atribuída aos picos endotérmicos observados entre 40 e $60^{\circ} \mathrm{C}$ em amostras novas, estes picos desaparecem na segunda varredura. Isto depende da variação entre a sub- $T_{g}$ e a $T_{g}$ e do tempo de envelhecimento [131]. Este comportamento já foi observado em glúten de trigo [141], cereais matinais [142], amilopectina [143], cadeias curtas de amilose [144], e amido de arroz nativo [145].

Bord et al. [132] analisou e comparou a entalpia durante o relaxamento dos polímeros sintéticos: poli(metacrilato de metila) (PMMA) e polivinilpirrolidona (PVP) com o de polissacarídeos hidratados para diferentes tempos e temperaturas, e verificou que durante o relaxamento estrutural que ocorre durante o armazenamento, surge um pico durante a recuperação, conhecido como sub- $T_{g}$, ultrapassando a região da transição vítrea. Com um aumento do tempo de envelhecimento, a amplitude e a posição do pico da entalpia aumenta na escala de temperatura, e, ao mudar a temperatura isso é mais significativo. As moléculas de amido extrudado, aparentemente, estão em equilíbrio, no entanto, a amilopectina e o phytoglycogen envelhecem um pouco mais rápido do que o PMMA e PVP hidratado sem atingir completamente o seu equilíbrio. 


\subsubsection{Teor de água}

O TPS é hidrofílico, logo, a alteração da humidade do ambiente altera o teor de água do amido, pois a dessorção da água da ligação de hidrogênio é lenta, quando comparada com a adsorção da água.

Analisando o comportamento mecânico durante o armazenamento em amidos com baixa umidade, nota-se uma fragilização progressiva e o material torna-se mais rígido, pois as cadeias de amido perdem mobilidade e ocorre uma densificação da matriz [130]. Dados de DMTA e DSC sugerem que a fragilização pode ocorrer devido à relaxação do volume livre, sub-Tg, durante o envelhecimento, bem como devido à perda de plastificante que ocorre durante a evaporação [131]. Aparentemente, a amilose retarda o relaxamento das regiões amorfas, em direção ao estado de equilíbrio [146].

Em filmes de amido de milho plastificado com glicerol e armazenadas por 90 dias, o teor de água (3,5 a 13,9\%) e a quantidade de cristalinidade tipo B (20 a 39\%) aumentaram, quando a umidade relativa do ambiente aumentou de 30 para 90\% [147]. Aparentemente, o aumento da umidade relativa do ambiente conduziu: a uma rede de amilose na matriz, e, as moléculas de amilopectina tenderam a ir para a região granular, para assim absorver água e inchar. Então, a plastificação do amido, decorrente do aumento do teor de água levou a uma maior mobilidade das moléculas de amido e subsequente maior cristalinidade do material.

\subsubsection{Plastificante}

Similar à umidade, outros plastificantes presentes no TPS podem lixiviar ou serem extraídos. Plastificantes com moléculas relativamente pequenas, em geral, não são voláteis o suficiente para migrar para a superfície do material. Outros plastificantes podem se separar em função de mudanças no teor de água ou ainda devido à sua compatibilidade com o TPS. As combinações de plastificantes criam diagramas de fase complexos que podem envolver cristalinidade e atrações mútuas.

Estudos mostraram que os filmes de amido obtidos com plastificantes contendo grupos amida são menos sensíveis aos efeitos do envelhecimento do que os 
plastificados com glicóis. No entanto, os filmes envelhecidos apresentam pouca flexibilidade interna, o que afeta negativamente as suas propriedades mecânicas [148].

A escolha do plastificante afeta tanto a cristalização como a sensibilidade à água. Assim, é muito importante escolher um plastificante que seja capaz de conferir flexibilidade ao TPS e suprimir a retrogradação durante o envelhecimento. A fim de alcançar este objetivo, vários plastificantes foram incorporados ao amido para formar o TPS, tais como: água, glicol, sorbitol, ureia, amido, açúcares e amina quaternária. Recentemente foi sugerido que o uso de alto teor de glicerol ou de plastificantes com outros grupos polares, que possuam maior interação com a estrutura molecular do amido, podem representar uma abordagem eficaz para impedir o envelhecimento [136]. A adição de monoestearato de glicerol (GMS) como agente tensoativo para filmes de TPS diminuiu sua tendência à retrogradação [149], e, este efeito é atribuído à formação de complexos amilose-GMS, os quais são favorecidos através da retrogradação da amilose

\subsubsection{Origem Botânica}

Os efeitos do envelhecimento dependem, entre outros assuntos, da origem botânica do amido. Em amidos de milho e de cevada, após 5 semanas foram observadas variações na rugosidade da superfície, ocorrendo separação de fases [150]. Já em amido de milho, mesmo após 270 dias não houve mudança nem na morfologia, nem na rugosidade da superfície [127].

\subsection{PARTE EXPERIMENTAL}

\subsubsection{Materiais}

Foram utilizados o Amide ${ }^{\circledR} 3001$, que é um amido de milho da Ingredion, água destilada, glicerol (peso molecular =92,09), e os ácidos carboxílicos:

- adípico puro (peso molecular $=146,14)$,

- cítrico anidro (peso molecular = 192,13), 
- málico DL (peso molecular = 134,09) e

- tartárico anidro P.A (peso molecular $=150,09$ ).

Todos foram obtidos na Casa Americana de artigos para Laboratórios.

\subsubsection{Métodos}

O método de preparação utilizado foi o mesmo descrito no item 3.3.2.1. A caracterização foi realizada 20 dias após o processamento dos materiais (material novo) e após 12 meses (material estocado).

O material ficou 12 meses estocado em uma bombona escura dentro de sacos, com a intenção de simular o ambiente de estocagem na indústria.

\subsubsection{Caracterização}

\subsubsection{Espectroscopia Vibracional de Absorção no infravermelho com transformada de Fourier (FTIR)}

As análises foram realizadas da mesma forma relatada no item 3.3.3.2.

\subsubsection{Termogravimetria}

As análises foram realizadas da mesma forma descrita no item 3.3.3.3.

\subsubsection{Calorimetria Exploratória Diferencial (DSC)}

As análises foram realizadas da mesma forma relatada no item 3.3.3.4.

\subsubsection{Difração de Raios X (DRX)}

As análises foram realizadas da mesma forma descrita no item 3.3.3.5.

\subsubsection{Microscopia Eletrônica de Varredura (MEV)}

As análises foram realizadas em um Microscópio Eletrônico de Varredura modelo FEG Inspect F50 e marca FEI Philips, localizado no Departamento de 
engenharia Metalúrgica e de Materiais na Escola Politécnica da Universidade de São Paulo. Primeiramente as amostras foram criofraturadas e recobertas com ouro.

\subsubsection{Propriedades Mecânicas: Ensaio de Tração}

As análises foram realizadas da mesma forma relatada no item 3.3.3.7.

\subsection{RESULTADOS E DISCUSSÕES}

Os resultados apresentados a seguir referem-se às amostras com $20 \%$ de umidade. Resultados referentes às amostras com 30\% de umidade não foram relatados porque não foram observadas diferenças significativas entre as amostras com 20 e $30 \%$ de umidade.

\subsubsection{Espectroscopia no Infravermelho FTIR}

A Figura 53 apresenta espectros FTIR das amostras sem ácido (SA) e com ácido málico, novas e envelhecidas. Era esperado que com o tempo o pico entre 3277$3262 \mathrm{~cm}^{-1}$ fosse deslocado para menores valores de número de onda, indicando: que as ligações $\mathrm{O}-\mathrm{H}$ foram reforçadas com o tempo, ou seja, que a interação entre amido e glicerol aumentou. $O$ deslocamento do pico poderia ter sido causado pela perda de glicerol, que reduz o movimento das cadeias de amido [151].

O pico entre $1371-1337 \mathrm{~cm}^{-1}$ era um dupleto nas amostras de SA2 novas, mas, nas amostras envelhecidas ele transformou-se em um pico único em $1337 \mathrm{~cm}^{-1}$.

O pico duplo entre 1000-950 $\mathrm{cm}^{-1}$ também transformou-se em um pico único com o envelhecimento, o que pode ser causado pela ordenação dos polímeros e pela redução do número de conformações [152] [153] [154]. Presume-se que o glicerol contribui para o estreitamento e formação de uma estrutura ordenada, devido à sua capacidade de aumentar a mobilidade das cadeias de amido.

As absorbâncias na região de $1100-900 \mathrm{~cm}^{-1}$ resultaram de interações envolvendo ligações $\mathrm{C}-\mathrm{O}$ e $\mathrm{C}-\mathrm{C}$ e mostraram-se sensíveis às alterações na cristalinidade. A banda em $1020 \mathrm{~cm}^{-1}$ é característica de amido amorfo, enquanto as 
proporções das intensidades das bandas 1040 e $1020 \mathrm{~cm}^{-1}$ podem estar relacionadas com a quantidade de ordenação de longo alcance e cristalinidade, em qualquer período de tempo, quando 1040 aumenta 1020 diminui [155].

Figura 53 - Espectros FTIR das amostras novas e estocadas com $20 \%$ de água: sem ácido SA2 (a) e com $2 \%$ em massa de ácido málico - AM2 (b).

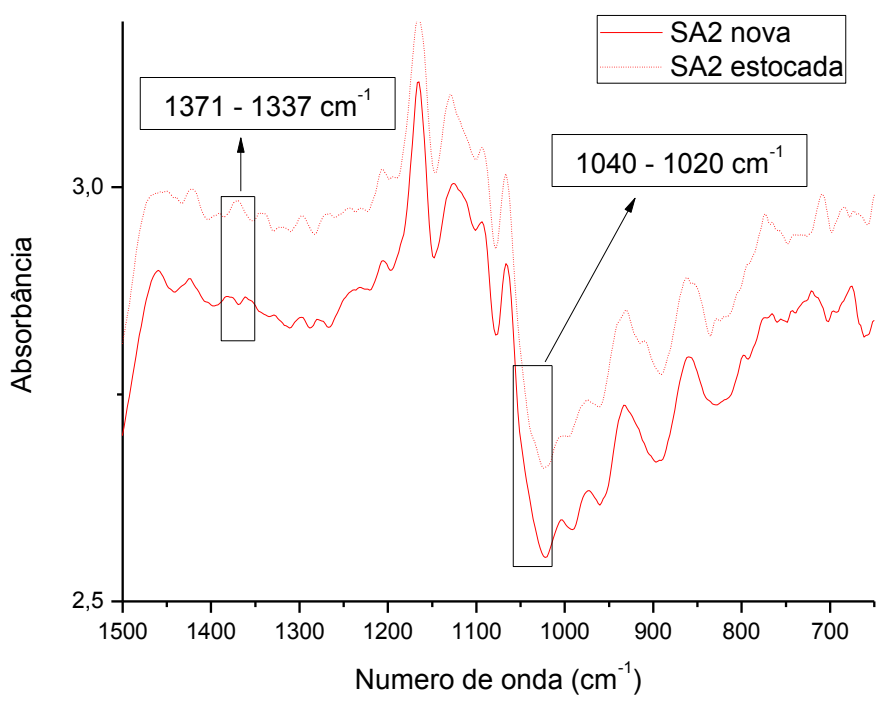

(a)

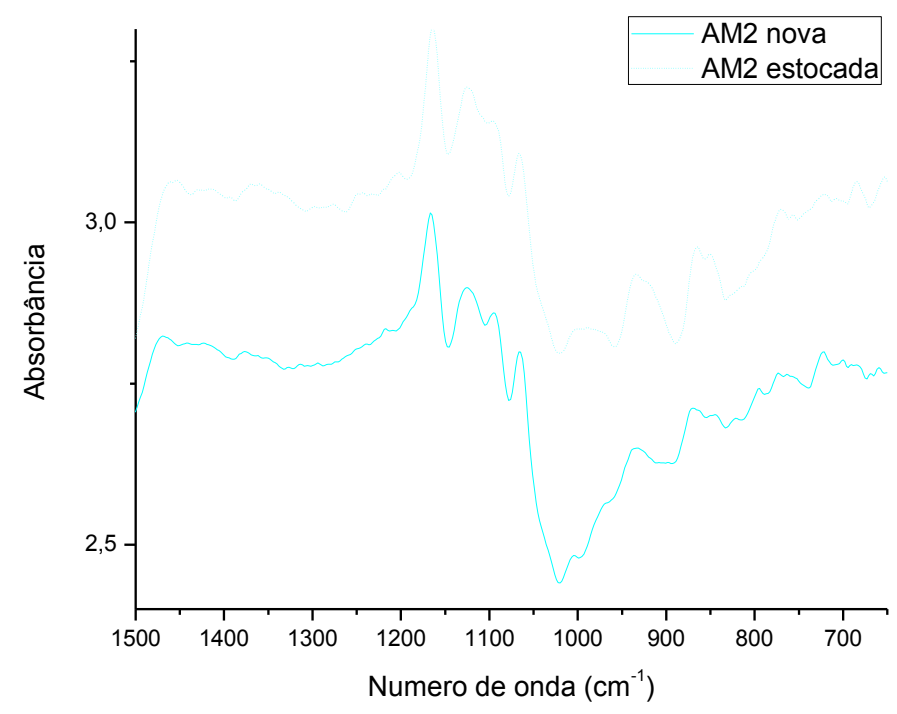

(b) 
Smits et al. [156] concluíram que as alterações espectroscópicas entre 1050 e $995 \mathrm{~cm}^{-1}$ indicam retrogradação de materiais a base de amido, armazenados a temperaturas acima da $\mathrm{T}_{\mathrm{g}}$. Estas alterações foram observadas nas amostras com ácido carboxílico.

\subsubsection{Análise Termogravimétrica}

A Figura 54 mostra as curvas DTG da análise termogravimétrica das amostras SA2, AA2 e AC2, novas e estocadas, com $20 \%$ de água. Pode-se observar que estas amostras apresentam uma mudança na curva DTG, devido à perda de glicerol durante o armazenamento, pois nota-se um menor teor deste material (primeira perda de massa). O mesmo não ocorre para as amostras com ácido tartárico e ácido málico (Figura 55) mostrando que estes ácidos, provavelmente, formam ligações mais fortes, retendo o plastificante. Em todas as amostras nota-se uma perda de massa inicial referente a perda de água.

Figura 54 - Curvas DTG das amostras SA2(a), AA2(b) e AC2(c) novas e estocadas com $20 \%$ em massa de água.

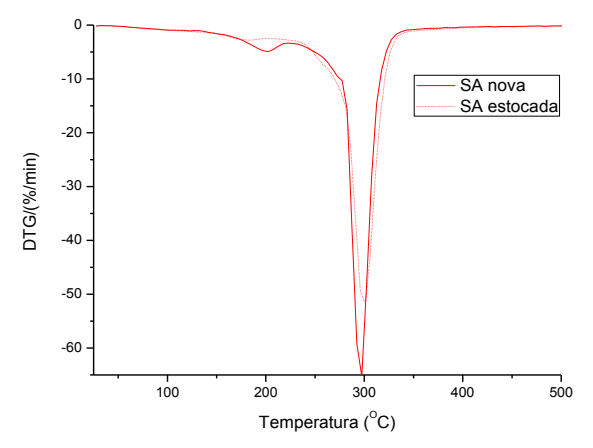

(a)

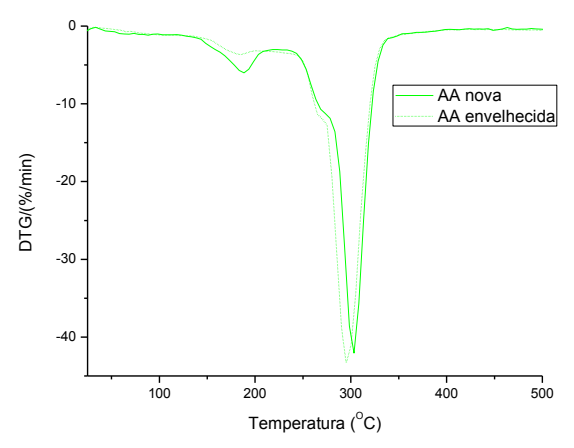

(b)

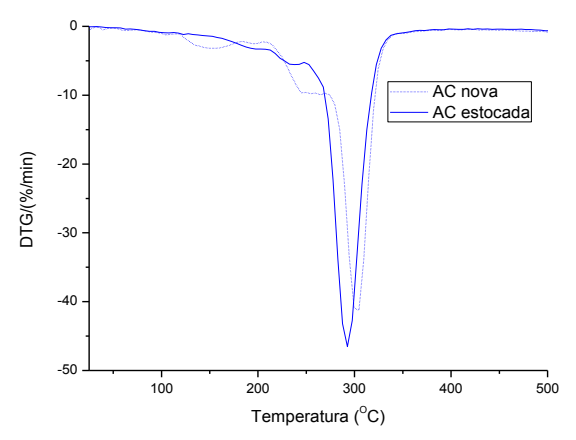

(c) 
Figura 55 - Curvas DTG das amostras AM2(a) e AT2(b) novas e estocadas.

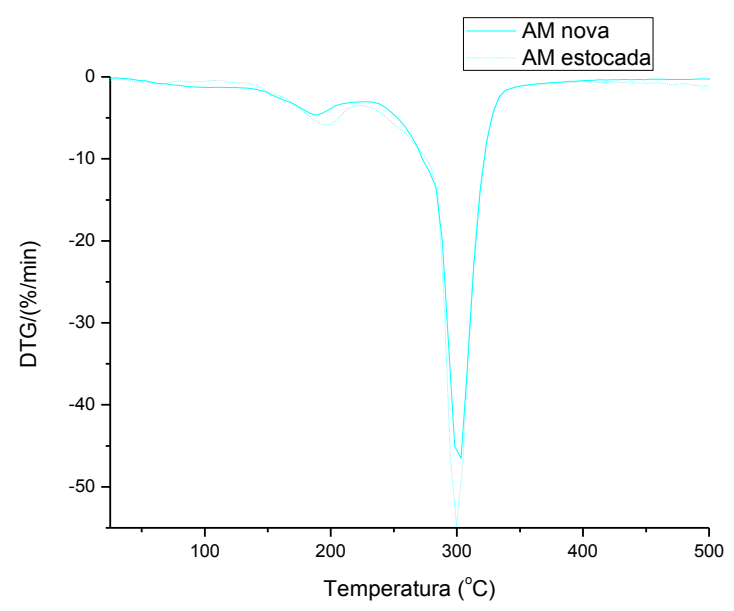

(a)

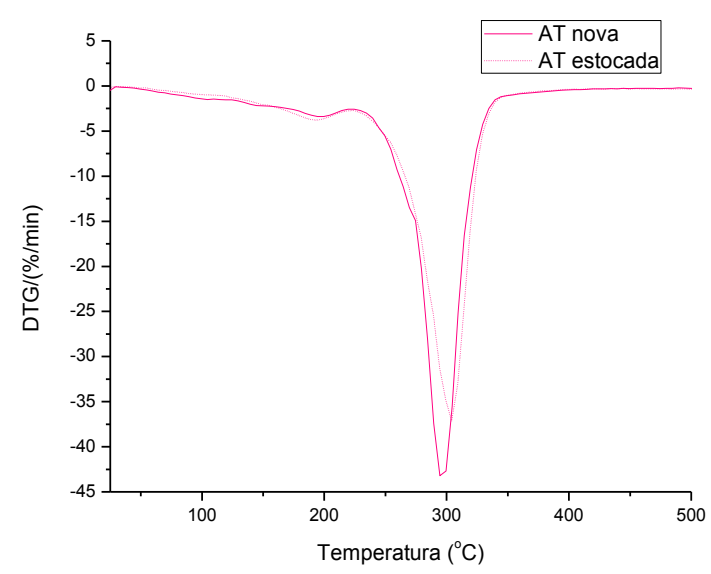

(b)

\subsubsection{Calorimetria Exploratória Diferencial (DSC)}

A Tabela 16 mostra a sub- $\mathrm{T}_{\mathrm{g}}, \mathrm{T}_{\mathrm{g}}$ e $\mathrm{T}_{\mathrm{m}}$ das amostras 7, 7mod, SA2, AA2, AC2, AM2 e AT2.

A $T_{g}$ e sua diferença com a temperatura ambiente são fatores vitais que influenciam a taxa de movimento macromolecular, cinética de cristalização, e a estabilidade física do TPS [155]. A mudança no valor da $T_{m}$ ocorre devido à recristalização do material, ou seja, a mudança na cristalinidade [136], o que será discutido na seção 4.4.4.

Pode-se observar um aumento na temperatura sub- $\mathrm{T}_{\mathrm{g}}$, considerada a fase rica em glicerol, nas amostras 7, 7mod, SA2 e AC2, e uma queda nos valores de $T_{g}$ da amostra AA2. A sub- $T_{g}$ aumenta, provavelmente, porque as ligações com o glicerol nas amostras sem ácido e com ácido cítrico são mais fracas, então com o tempo, uma porção do glicerol é exudada da amostra. Ao diminuir a concentração de glicerol, as cadeias de amido que estavam alinhados entre si formando uma rede compacta, deixam de estar tão bem alinhadas.

Ainda para essas amostras: 7, 7mod, SA2, AC2 ocorre uma queda na $T_{g}$. A Tg está relacionada com a fase rica em amido, e sua queda pode ocorrer devido à própria reação entre o amido e o ácido cítrico, devido a estequiometria deste ácido. Vale 
lembrar que o plastificante consegue aumentar os espaços entre as cadeias, facilitando a movimentação das moléculas.

O oposto ocorre na amostra AA2, ou seja, a Sub- $T_{g}$ diminui e a $T_{g}$ aumenta. Este ácido é o mais polar, logo ao ser armazenado, esse material pode reagir com a umidade do ambiente, formando mais pontes de hidrogênio entre amido e glicerol, já que estes estavam instáveis e o ácido adípico não tem hidroxila. Dessa forma, este material com o tempo terá mais mobilidade entre as cadeias de amido, por isso a $T_{g}$ aumenta.

Tabela 16 - Sub $T_{g}, T_{g}$ e $T_{m}$ das amostras 7, 7mod, SA2, AA2, AC2, AM2 e AT2

\begin{tabular}{c|cc|cc|cc}
\hline Amostra & \multicolumn{2}{|c|}{ Sub-T $\left({ }^{\circ} \mathbf{C}\right)$} & \multicolumn{2}{|c|}{$\mathbf{T}_{\mathbf{g}}\left({ }^{\circ} \mathbf{C}\right)$} & \multicolumn{2}{c}{$\mathrm{T}_{\mathbf{M}}\left({ }^{\circ} \mathbf{C}\right)$} \\
\hline & Nova & $\begin{array}{c}\text { Após 12 } \\
\text { meses }\end{array}$ & Nova & $\begin{array}{c}\text { Após 12 } \\
\text { meses }\end{array}$ & Nova & $\begin{array}{c}\text { Após 12 } \\
\text { meses }\end{array}$ \\
7 & -84 & -75 & 33 & 25 & 89 & 113 \\
7 mod & -86 & -76 & 49 & 44 & 153 & 130 \\
SA2 & -84 & -78 & 55 & 42 & 134 & 530 \\
$A A 2$ & -70 & -87 & 34 & 53 & 94 & 251 \\
$A C 2$ & -85 & -80 & 48 & 38 & 92 & 322 \\
$A M 2$ & -85 & -87 & 51 & 50 & 102 & 294 \\
$A T 2$ & -85 & -86 & 48 & 50 & 107 & 187 \\
\hline
\end{tabular}

Nas amostras AM2 e AT2 tanto os valores da Sub- $T_{g}$ quanto da $T_{g}$ praticamente não foram alterados.

Chung e Lim [157] afirmaram que o envelhecimento do TPS a temperaturas acima da $\mathrm{Tg}$ resulta em um aumento da mobilidade molecular e retrogradação do amido amorfo. Vodovotz e Chinachoti [158] também relatou que o envelhecimento dos géis de amido de trigo levaram a formação de redes densas de amido, com distribuição desigual de água e uma Sub-Tg maior em relação as amostras novas. 
Apenas a amostra 7 mod possui um aumento da $\mathrm{Tm}$. Esta amostra possui um maior teor de ácido cítrico, o que facilita a formação do anidrido e, consequentemente, a substituição nucleofílica, formando citrato de amido e citrato de di-amido. Isto não ocorre para a amostra 7 porque ela foi processada a $100^{\circ} \mathrm{C}$, ou seja, a formação do anidrido é mais difícil de ocorrer.

Em todas as outras amostras ocorre um aumento da $T_{m}$, sendo este aumento menor para as amostras com ácido málico e tartárico, devido a liberação de plastificante.

Nas amostras de TPS com ácido málico e com ácido tartárico (e glicerol), ocorre esterificação espontânea. Quanto maior a massa molar do TPS, mais difícil de ocorrer a movimentação das moléculas.

\subsubsection{Difração de Raios X (DRX)}

A Figura 56 mostra o DRX das amostra com ácido cítrico. Analisando a influencia da temperatura de processamento nas amostras com ácido cítrico nota-se que as curvas das amostra 7 e 7 mod apresentam mudança nos picos de difração referentes às estruturas $V_{A}$ e $E_{H}$. $O$ pico em $2 \theta=13,4^{\circ}$ desloca-se para $2 \theta=15,8^{\circ}$, o que pode indicar uma mudança de estrutura cristalina. Ao verificar a mudança na amostra com $2 \%$ de ácido cítrico, os picos referentes a estrutura $V_{a}$ desaparecem com o tempo. Este resultado corrobora com os resultados da $\mathrm{Tm}$.

Nos TPS contendo glicerol, a amilose e a amilopectina recristalizam com o tempo. No nível molecular, uma série de alterações estruturais ocorre durante o armazenamento acima da temperatura de transição vítrea. Primeiro, hélices duplas e agregados de hélices duplas (de curto alcance) são formados e, em seguida, a cristalização (ordenação de longo alcance) ocorre. A taxa de cristalização também é influenciada pelo teor de amilose, que varia de acordo com a origem do amido. A amilose cristaliza mais rápido do que as cadeias externas de amilopectina. A cocristalização de amilopectina com amilose ocorre durante a retrogradação do amido [117] [134][134][137]. 
Durante o envelhecimento, o conteúdo de plastificante de amido afeta a taxa de cristalização. Quantidades mais elevadas de plastificante causam aumento na mobilidade das cadeias de amido e queda na temperatura de transição vítrea. A taxa de cristalização aumenta com o aumento do teor de água. Por outro lado, o glicerol reduz a taxa de cristalização devido as interações amido-glicerol, o que causa redução tanto na mobilidade do amido quanto na estabilização da água [117][134][143][159][160].

Figura 56 - Curvas de raios $X$ das amostras novas e envelhecidas 7(a), $7 \bmod (b)$ e AC2(c).

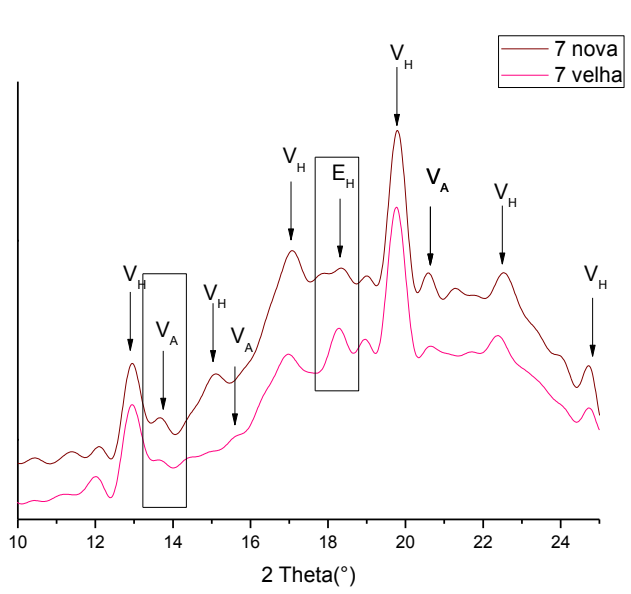

(a)

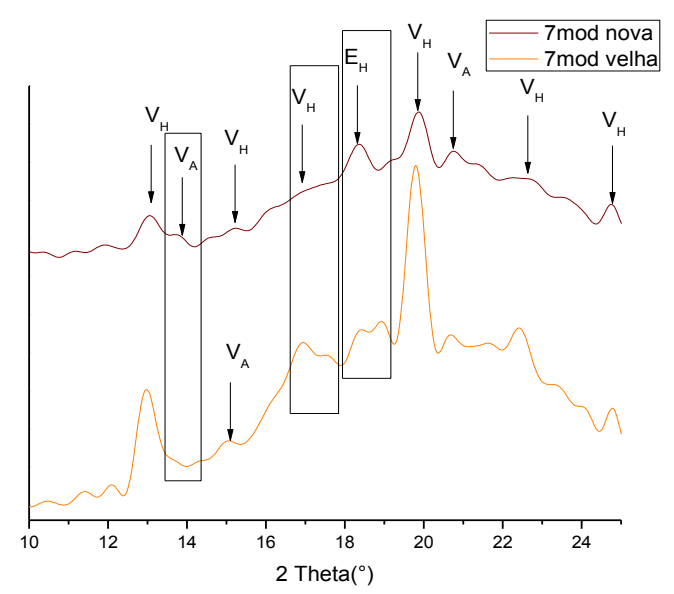

(b)

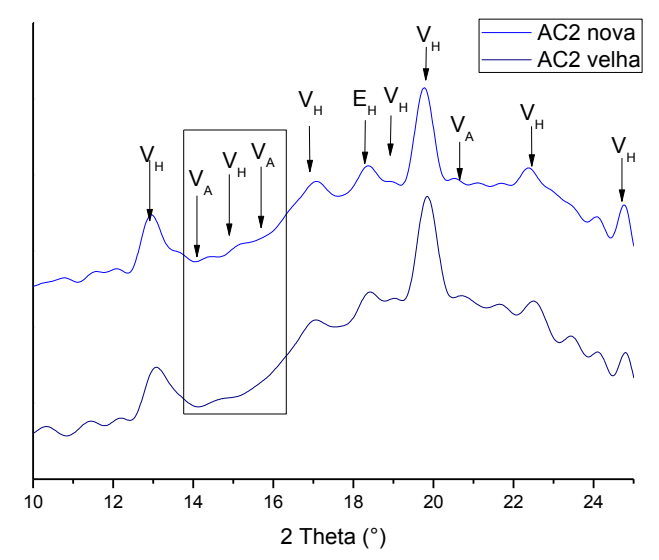

(c)

A Figura 57 mostra o DRX das amostras sem ácido e com ácido adípico, málico e tartárico. Nas amostras com os ácidos málico e tartárico não foi observada mudança significativa dos picos de difração. Nas amostras sem ácido é nítido que após a 
estocagem a estrutura $\mathrm{E}_{\mathrm{H}}$ desaparece, bem como alguns picos da estrutura $\mathrm{V}_{\mathrm{A}}$. $\mathrm{O}$ mesmo ocorre para as amostras com ácido adípico.

Figura 57 - Curvas de raios $X$ das amostras novas e envelhecidas sem ácido(a), ácido adípico(b), ácido málico(c) e ácido tartárico(d).

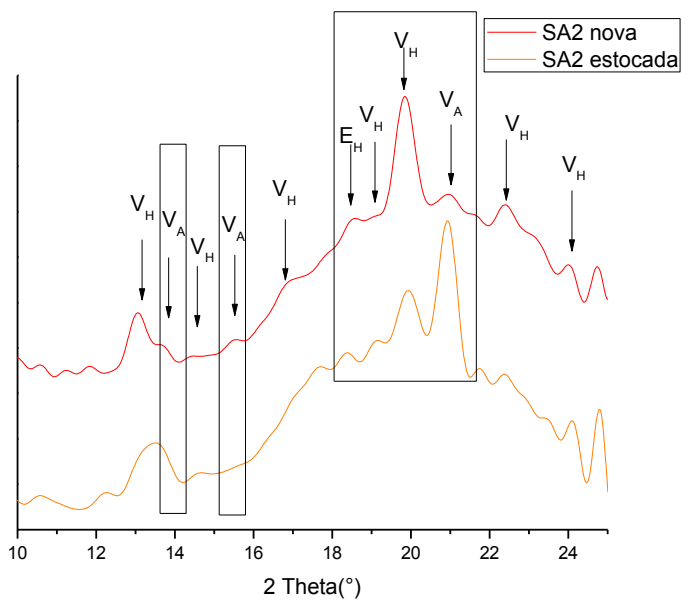

(a)

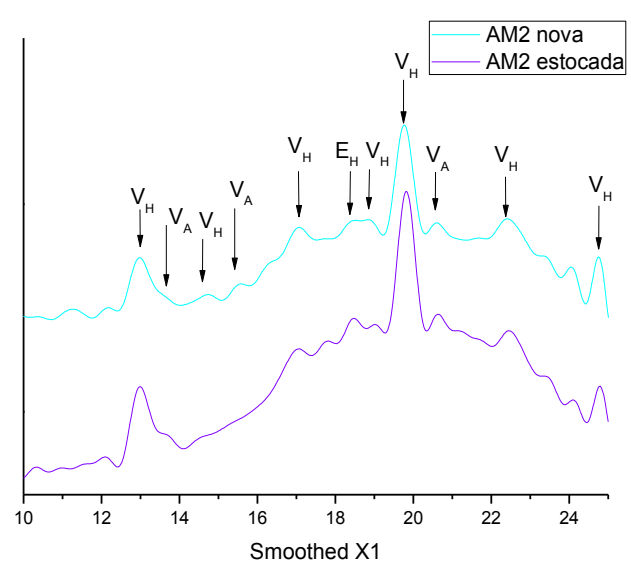

(c)

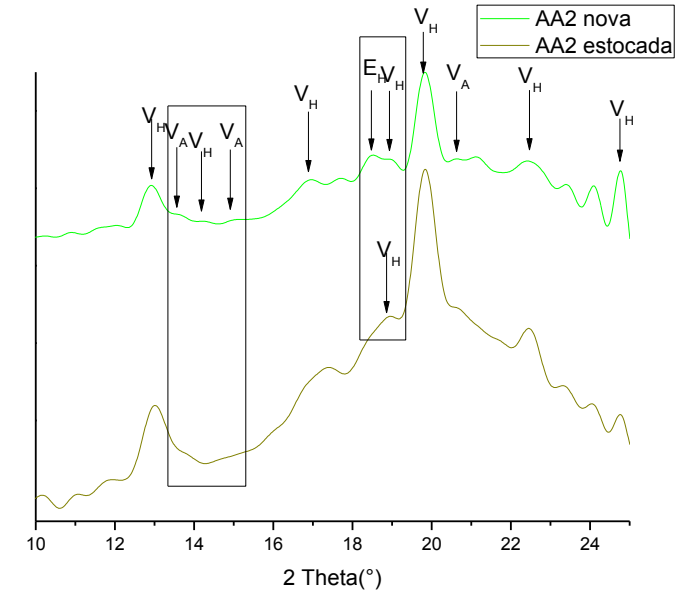

(b)

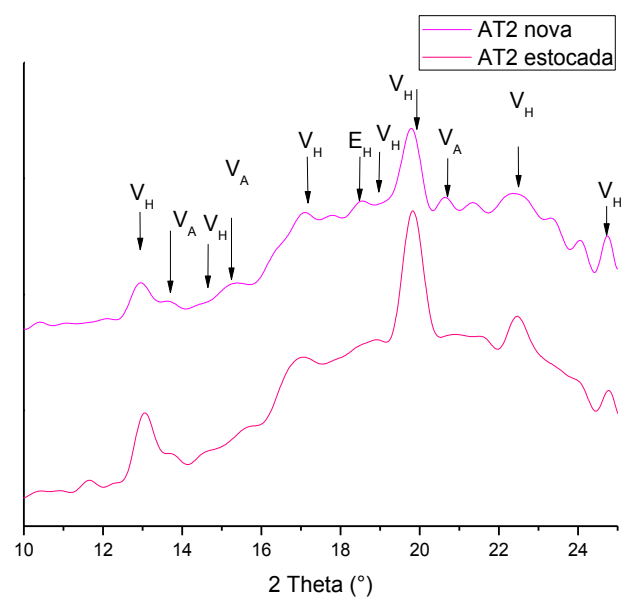

(d)

\subsubsection{Microscopia Eletrônica de Varredura (MEV)}

A Tabela 17 mostra as micrografias das amostras novas e estocadas com aumento de 1000x. Pode-se notar na amostra SA2 envelhecida a presença de alguns grânulos de amido. Isto pode ocorrer devido exudação do plastificante e a mudança da cristalinidade, que foi observada no ensaio de DRX. Entretanto, nas outras amostras não houve mudança significativa. 
Tabela 17 - Micrografia com aumento de 100x das amostras novas e estocadas.

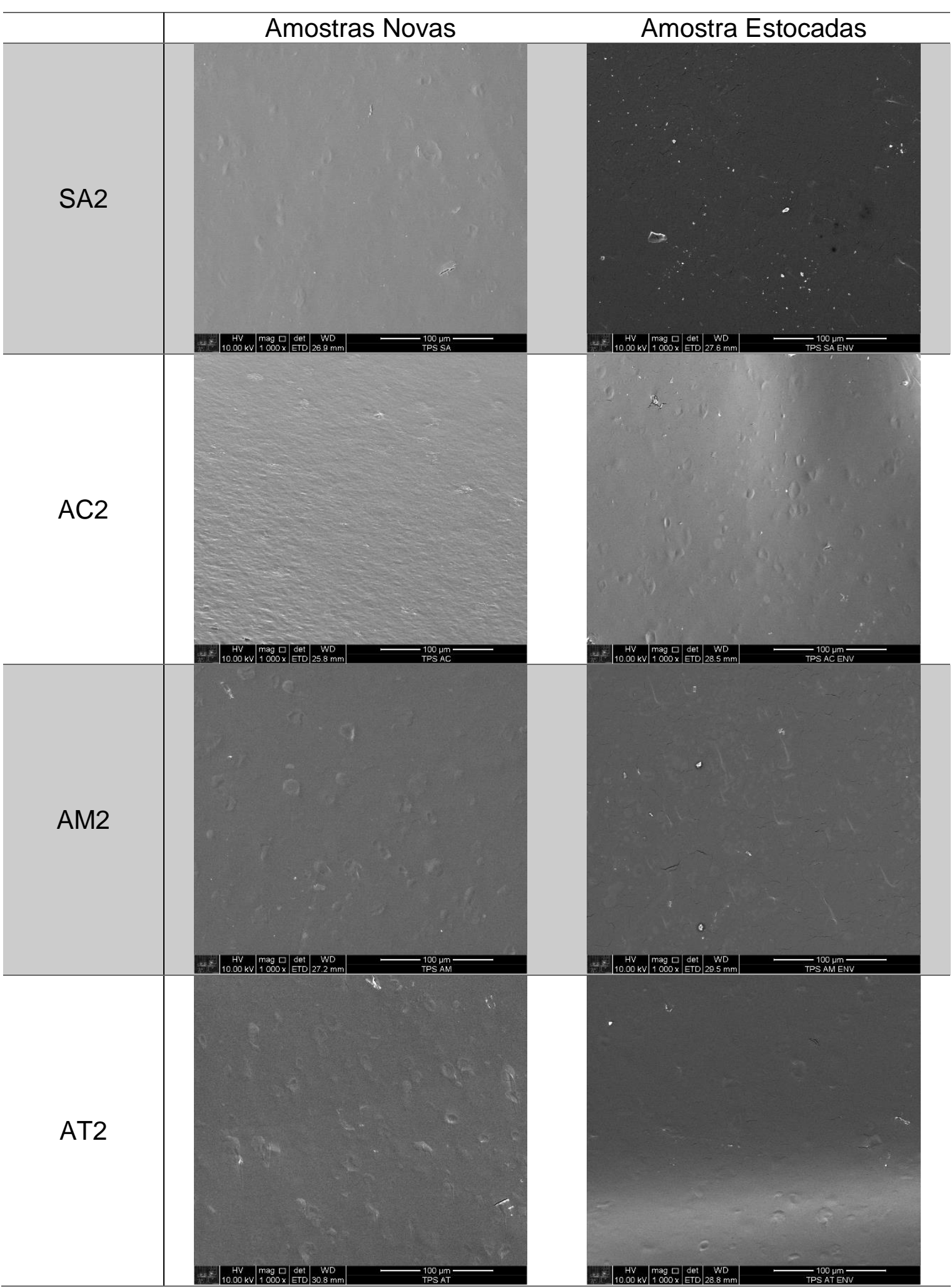




\subsubsection{Propriedades Mecânicas: Ensaio de Tração}

A Figura 58 mostra as propriedades mecânicas: Módulo elasticidade, Resistência à tração e Alongamento na ruptura das amostras novas e estocadas (a) amostras sem ácido, (b) amostras com 2\% de ácido adípico, (c) amostras com $4 \%$ de ácido cítrico, (d) amostras com $2 \%$ de ácido cítrico, (e) amostras com $2 \%$ de ácido málico, (f) amostras com $2 \%$ de ácido tartárico. Comparando as amostras novas e estocadas nota-se que apenas as amostras com ácido málico e ácido tartárico não sofreram alteração nos valores de propriedades mecânicas em função do tempo de estocagem.

Analisando as amostras 7 e $7 \mathrm{mod}$, ambas com 4\% de ácido cítrico e $30 \%$ de umidade, nota-se uma diferença no comportamento, de acordo com a temperatura de processamento. Os valores de módulo de elasticidade e de resistência à tração de ambas aumentam após 12 meses de estocagem, quando comparados com os valores obtidos após 20 dias de processamento. Na amostra 7, que foi processada a $100^{\circ} \mathrm{C}$, os valores de alongamento na ruptura também aumentam, e na amostra $7 \mathrm{mod}$, processada a $125^{\circ} \mathrm{C}$, diminuem. Pode-se notar que nas amostras sem ácido, com $2 \%$ de ácido cítrico e com $2 \%$ de ácido adípico, todas processadas a $125^{\circ} \mathrm{C}$, os valores de alongamento diminuem após estocagem, quando comparados com os valores obtidos para as mesmas amostras não estocadas.

Observando as amostras com ácido adípico, verifica-se que estas são as únicas em que os valores de módulo de elasticidade e de resistência à tração diminuem após estocagem, mas, assim como as demais amostras processadas a $125^{\circ} \mathrm{C}$, os valores de alongamento na ruptura diminuem, quando comparados com os obtidos para as mesmas amostras após 20 dias de processamento. 
Figura 58- Módulo de elasticidade, Resistência à tração e Alongamento na ruptura das amostras novas e estocadas por 12 meses: (a) amostras sem ácido, (b) amostras com $2 \%$ de ácido adípico, (c) amostras com $4 \%$ de ácido cítrico, (d) amostras com $2 \%$ de ácido cítrico, (e) amostras com $2 \%$ de ácido málico, (f) amostras com $2 \%$ de ácido tartárico.
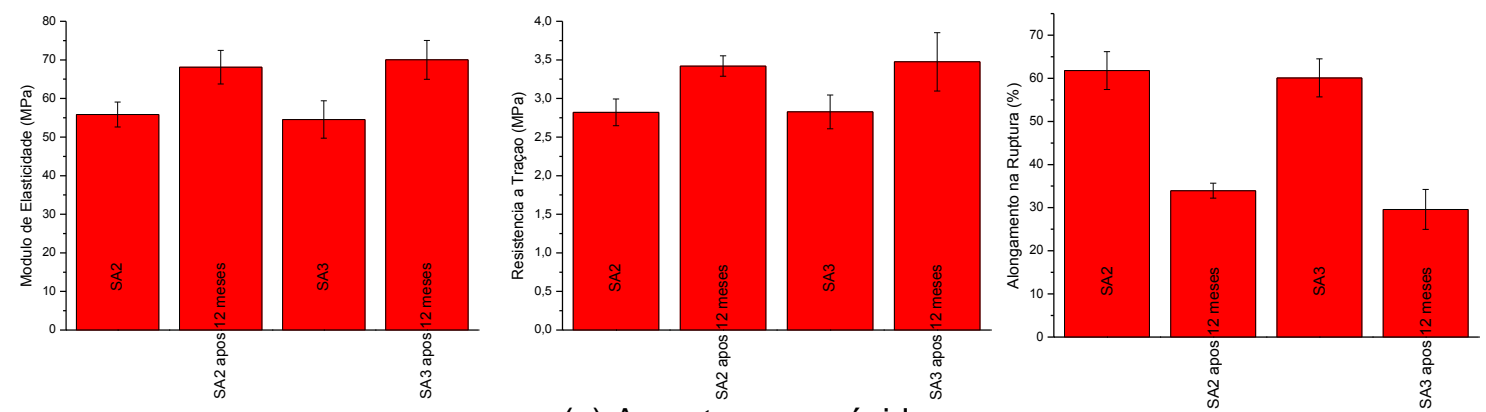

(a) Amostras sem ácido
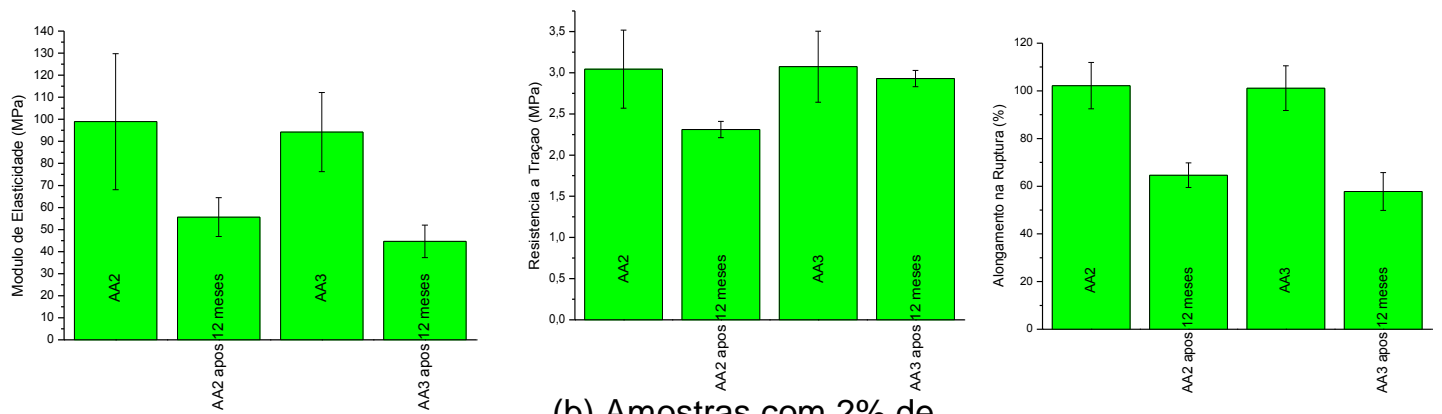

(b) Amostras com $2 \%$ de ácido adípico
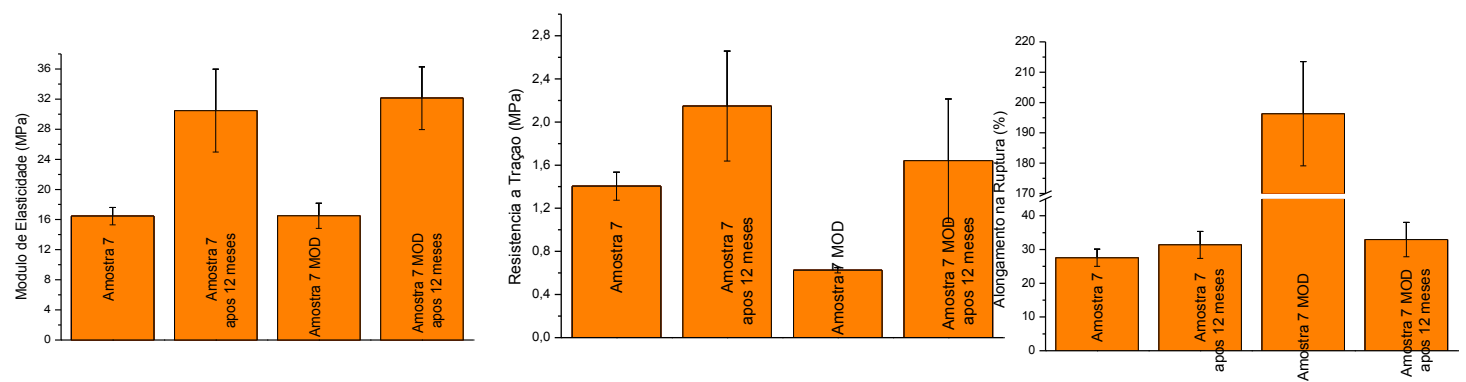

(c) Amostras com $4 \%$ de ácido cítrico 


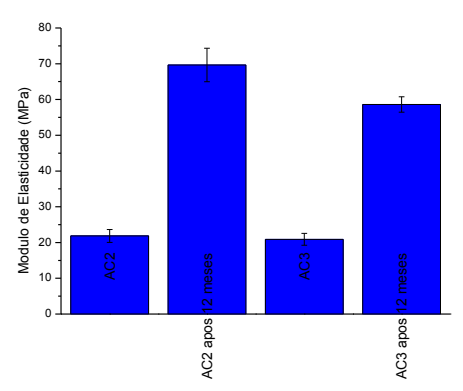

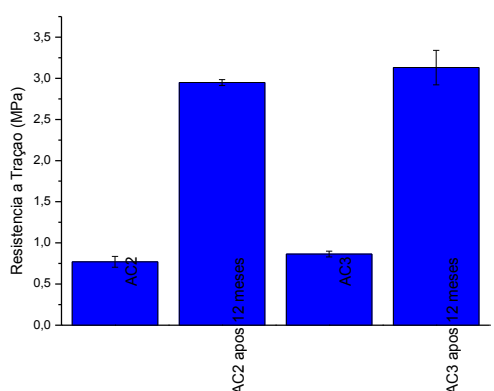

(d) Amostras com $2 \%$ de ácido cítrico
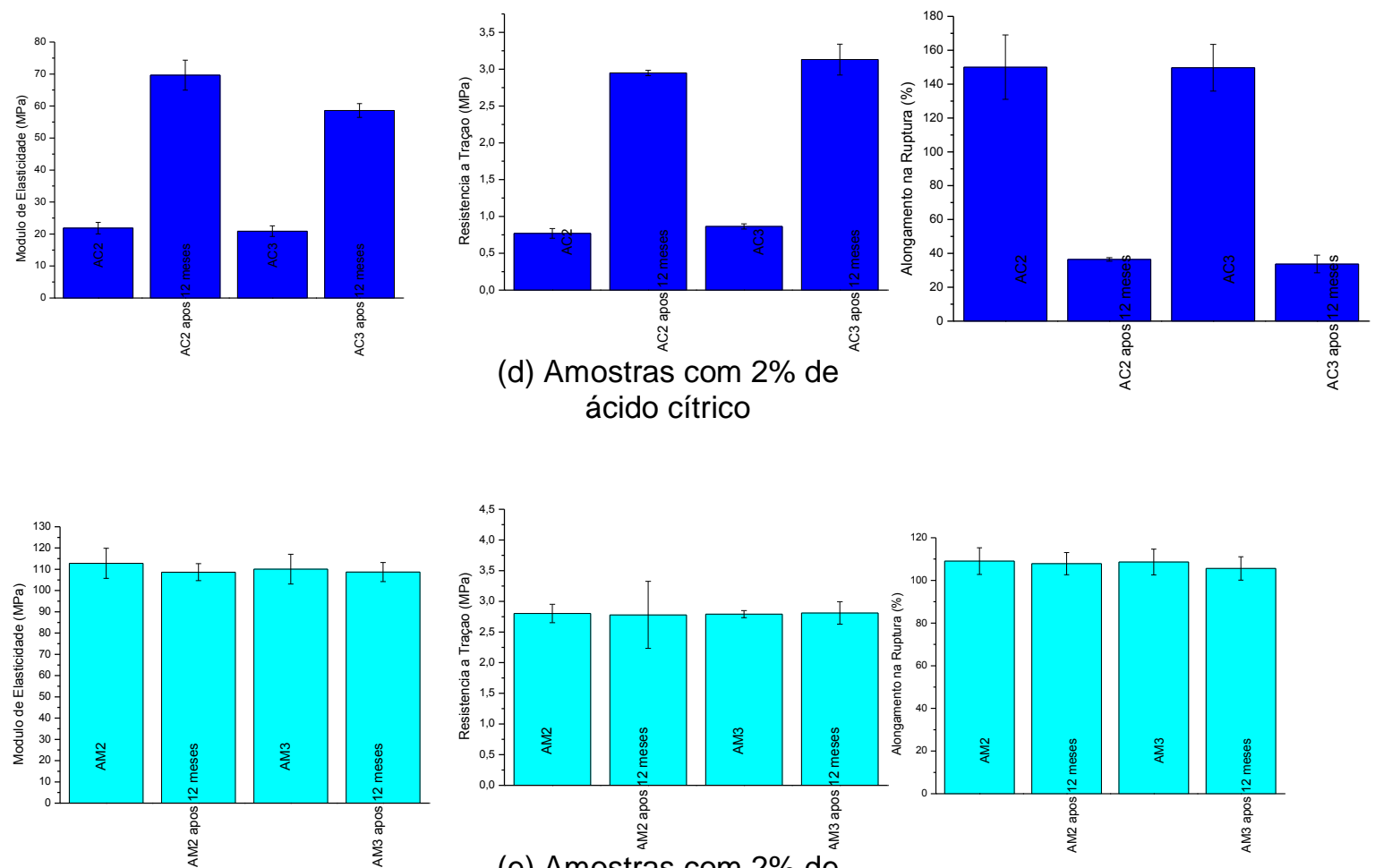

(e) Amostras com $2 \%$ de ácido malico
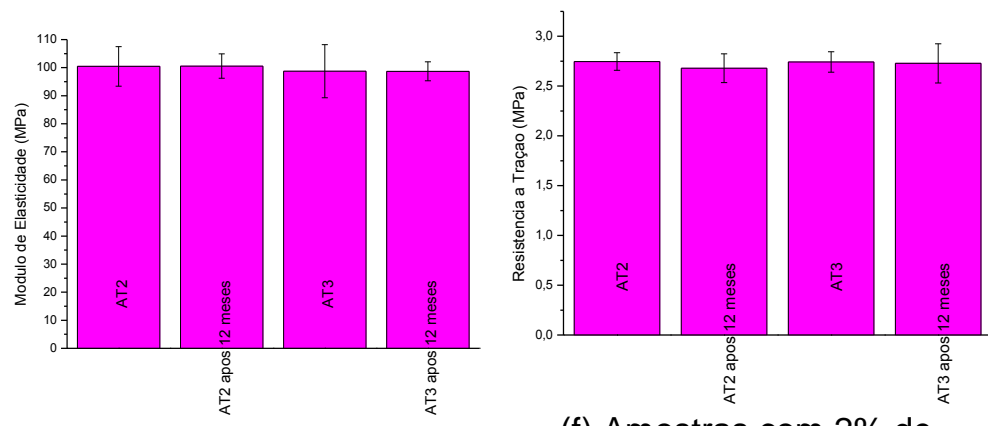

(f) Amostras com $2 \%$ de

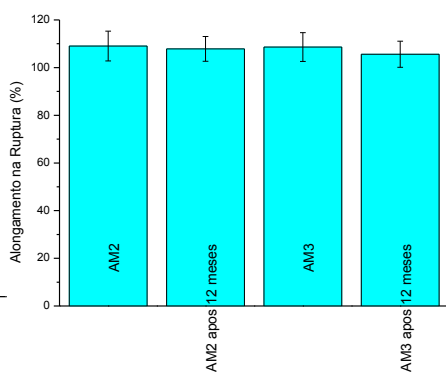
ácido tartárico

\subsection{CONCLUSÕES DO CAPÍTULO}

Neste capítulo foi realizado o estudo do envelhecimento do TPS de amido de milho com a composição de 30\% em massa de glicerol, 20 e 30\% em massa de água e $2 \%$ em massa de ácido carboxílico (adípico, cítrico, málico e tartárico). Foi apresentada uma revisão bibliográfica contendo estudos sobre as mudanças que podem ocorrer no TPS durante o seu envelhecimento. Na parte experimental, foi 
realizado um estudo comparativo das amostras após 20 dias de processamento e após um ano. As seguintes observações podem ser feitas a partir dos resultados apresentados neste capítulo:

- As amostras sem e com ácido cítrico apresentaram deslocamento e/ou desaparecimento de picos nos espectros infravermelho, indicando que houve retrogradação destes materiais. Os resultados obtidos por FTIR foram confirmados por mudanças nos valores de $T_{g}$, na estrutura cristalina das amostras e nas propriedades mecânicas;

- As amostras com ácido adípico apresentaram um comportamento térmico diferente das demais, em função do tempo de estocagem. As amostras estocadas apresentaram redução nos valores de propriedades mecânicas, quando comparadas com as amostras novas.

- As amostras com ácido málico e ácido tartárico não sofreram mudanças após o envelhecimento. Estes ácidos são mais estáveis e são capazes de formar ligações mais fortes e mais estáveis do que os demais ácidos. Porém, com maiores tempos de estocagem estas amostras possam sofrer alterações. 


\section{CAPÍTULO 5: BLENDA DE PP COM TPS}

\subsection{INTRODUÇÃO}

Neste Capítulo, primeiramente, será feita uma pequena revisão bibliográfica sobre blendas poliméricas e blendas de PP com TPS. Após, será analisado o efeito da adição de ácidos carboxílicos na blenda PP/TPS.

\subsection{REVISÃO BIBLIOGRÁFICA}

\subsubsection{Generalidades}

Segundo Utracki [161], blendas poliméricas são definidas como a mistura de 2 ou mais polímeros (ou copolímeros) sendo que suas composições são superiores a $2 \%$ em massa. São normalmente obtidas por meio de mistura mecânica do polímero fundido, geralmente feito em extrusora.

As blendas representam hoje cerca de $1 / 3$ do mercado de polímeros [161] sendo utilizadas em diversas aplicações, principalmente na indústria de embalagens, automotiva, aeroespacial e de bens de consumo (eletroeletrônicos, utensílios em geral, etc.). Isso ocorre, pois o desenvolvimento de blendas tem o custo de desenvolvimento muito inferior ao custo de desenvolvimento de novos polímeros, e, ao mesmo tempo, conseguem produzir um material com propriedades que são as combinações das propriedades dos polímeros formadores da blenda. [161]

Em geral, materiais de amido puro possuem propriedades mecânicas inferiores às encontradas em polímeros comuns, como os commodities, tais como baixa estabilidade térmica e alta sensibilidade a umidade, o TPS é misturado a outros polímeros como o PLA, PCL, PBSA, poli(hidroxi éter éster) e PE. O problema na preparação destas misturas é a diferença significativa nas propriedades reológicas dos dois polímeros [162]. 


\subsubsection{Blendas Poliméricas}

As propriedades das blendas poliméricas são determinadas pela morfologia, tamanho, forma e distribuição dos componentes da blenda. A morfologia resultante da mistura de polímeros depende das propriedades interfaciais e reológicas dos componentes e, frequentemente, das condições de processamento [163] [164][165].

Em geral a morfologia das blendas poliméricas pode apresentar-se de três formas distintas: dispersa, fibrilar, lamelar e co-contínuas [163]. Na morfologia dispersa, ou de gota, o componente em menor quantidade forma domínios esféricos na matriz, sendo esta morfologia o tipo mais comum [166].

A morfologia fibrilar se destaca dos outros tipos de morfologia. Pois possui melhores propriedades de resistência à tração [167].

A morfologia lamelar é interessante quando se deseja melhorar propriedades de barreira, e podem ser obtidas a partir da orientação das cadeias do polímero nos moldes de injeção [163][168].

A morfologia co-contínua é uma morfologia normalmente observada em blendas de composição equivalente entre os componentes e apresentam estruturas estáveis de forma alongada, cujos domínios não sofrem quebra nem retração, com interconexão entre estas estruturas. São formadas em composições próximas do ponto de inversão de fase, e ambos os componentes contribuem igualmente nas propriedades da blenda em todas as direções [167].

Os fatores físico-químicos que influenciam as propriedades finais de uma blenda durante a sua manufatura, desde a mistura dos polímeros no estado fundido, está ilustrado na Figura 59.

De maneira simples pode ser dito que existem quatro fatores que influenciam a morfologia de blendas poliméricas:

- tensão interfacial entre os polímeros formadores da blenda;

- as propriedades reológicas dos polímeros formadores da blenda;

- o processamento;

- a composição da blenda. 
Figura 59 - Fatores que contribuem para as propriedades finais de uma blenda.

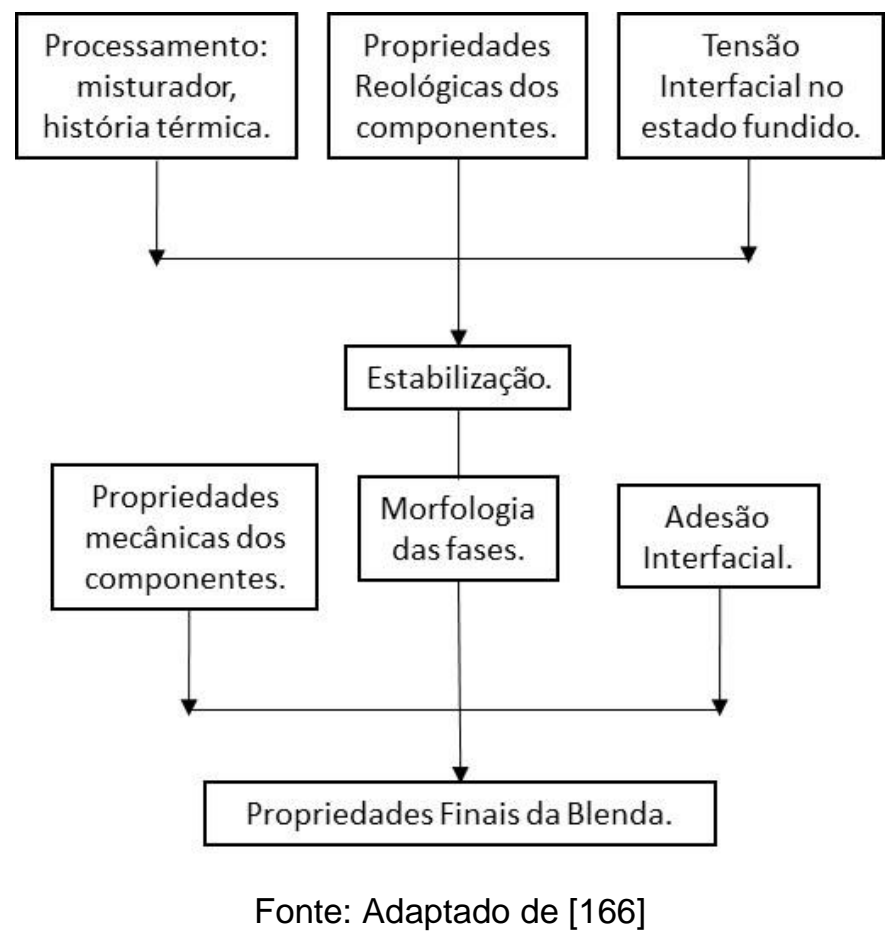

\subsubsection{Tensão Interfacial}

A tensão interfacial é o parâmetro chave no controle de compatibilidade entre os constituintes de uma mistura de polímeros e, é também, o parâmetro mais acessível que descreve as propriedades termodinâmicas e estruturais na interface de uma blenda polimérica e, por consequência, a compatibilidade entre seus componentes [169]. Se uma fase condensada forma uma interface com outra fase ou o vácuo, as propriedades físicas da interface devem ser incorporadas na descrição do comportamento energético da fase.

A tensão interfacial pode ser definida como o trabalho necessário para criar uma unidade de área interfacial à temperatura $\mathrm{T}$, pressão $\mathrm{P}$ e número de moléculas $\mathrm{N}$ constantes [170]. Em termos termodinâmicos a tensão interfacial pode ser identificada como um incremento na energia livre de Gibbs, por incremento de área.

Dentre os métodos para a determinação de tensão interfacial têm-se métodos estatísticos baseados na determinação de uma gota pendente, de uma gota séssil ou de uma gota girante; os métodos dinâmicos como instabilidades de fibras inseridas - 
breaking thread - e retração de fibras inseridas - imbedded fiber retraction - e os métodos reológicos [171].

\subsubsection{Propriedades reológicas dos polímeros formadores da blenda}

A morfologia de uma mistura depende das propriedades reológicas de seus componentes. Um dos fatores que tem papel essencial na determinação da morfologia de uma mistura polimérica é a razão de viscosidade $\left(\lambda_{v}\right)$ entre os componentes da mistura, vista na Equação 11 [172].

$$
\lambda_{v}=\frac{\eta_{d}}{\eta_{m}}
$$

Onde $\eta_{d}$ é a viscosidade da fase dispersa e $\eta_{m}$ é a viscosidade da matriz.

Wu [173] estabelece que uma "morfologia fina" de gotas é obtida quando a razão de viscosidade varia de $1 / 3$ a 1 , valores muito próximos a 1 não favorecem 0 processo de quebra da fase dispersa, e a obtenção de gotas "finas".

\subsubsection{Processamento}

O tipo de processamento utilizado para obter a mistura determina o fluxo ao qual o material é submetido durante o processamento, condicionando a morfologia resultante.

Quando se utiliza o processo de extrusão para misturar uma mistura, o material sofre fluxo extensional que promove a tendência à formação de fibras na fase dispersa, morfologia fibrilar. Através do recozimento da morfologia fibrilar, podem-se evitar processos de quebra e coalescência de gotas, resultando em uma morfologia de dispersão de gotas. No caso de misturadores internos ou câmaras de mistura, é favorecida a obtenção da morfologia de dispersão de gotas [172].

\subsubsection{Composição da Blenda}

A composição da mistura afeta diretamente a morfologia da mistura polimérica. As composições para cada região dependem da razão de viscosidade dos polímeros 
formadores da mistura. De uma forma simples, pode-se definir que, para misturas poliméricas binárias formadas por polímeros $A$ e $B$, existem três tipos de morfologia, dependendo da composição utilizada:

- Região onde a fase A encontra-se dispersa na matriz B;

- Região intermediária de inversão de fase onde A e B apresentam-se na forma contínua (morfologia co-contínua ou lamela) e

- Região onde a fase B encontra-se dispersa na matriz A.

De forma geral, o componente polimérico de menor viscosidade constitui a matriz quando presente em quantidade suficiente e o de maior viscosidade constitui a fase dispersa. Quando os polímeros têm valores de viscosidade e concentração muito próximos é comum a formação da morfologia co-contínua [174].

\subsubsection{Compatibilização de Blendas}

Compatibilizantes são substâncias que através de reações físico-químicas tem a função de agir na interface das blendas, e assim, reduzem as tensões interfaciais dos componentes da blenda modificando a morfologia final da blenda [161]. Assim, o controle da morfologia é extremamente importante para controlar a compatibilidade e melhorar as propriedades da blenda.

Se o compatibilizante tiver afinidade com ambas as fases da blenda, ele tende a migrar para a interface facilitando a adesão entre elas.

É desejável as blendas terem uma certa compatibilidade para se ter uma boa adesão entre os componentes, facilitando a transferência de tensão entre as fases.

Os compatibilizantes têm a função principal de: reduzir a tensão interfacial, estabilizar a morfologia contra a ação da temperatura ou de cisalhamento durante o processamento e promover a adesão interfacial no estado sólido [161].

\subsubsection{Redução da Tensão Interfacial}

A tensão interfacial entre polímeros é um parâmetro de controle de eficiência. Com a adição do agente compatibilizante em uma mistura binária a tensão interfacial 
entre seus componentes diminui. Já foi observado que ao aumentar a concentração de compatibilizantes ocorre a queda da tensão interfacial até uma concentração crítica, para o qual os valores da tensão interfacial permanecem constantes [175].

\subsubsection{Redução da coalescência}

A presença de um agente compatibilizante na interface entre dois polímeros resulta na dificuldade de mobilidade desta interface, reduzindo a coalescência. Quando um agente compatibilizante é adicionado numa mistura, ocorre um fenômeno de repulsão entre as moléculas do compatibilizante, localizadas na interface entre a fase dispersa e a matriz. Esta repulsão faz com que as gotas não consigam se aproximar umas das outras impedindo que se juntem, sendo necessária uma força maior para que as partículas se juntem e a coalescência ocorra. Além disso, as moléculas da matriz emaranhadas com as moléculas do agente compatibilizante apresentam dificuldades para drenar o filme existente entre as partículas da fase dispersa, inibindo a coalescência. Esses dois fenômenos resultam numa queda da coalescência na fase dispersa, quando um agente compatibilizante é adicionado à blenda.

\subsubsection{Aumento de adesão entre as fases}

A adesão entre as duas fases de uma mistura é governada pela tensão interfacial entre os dois componentes formadores da mistura, como mostra a Equação 12 [176].

$$
W_{a}=\gamma_{\text {sop } 1}+\gamma_{\text {sup 2 }}-\gamma
$$

Onde $W_{a}$ é o trabalho de adesão entre as duas fases, Ysup1 e Ysup2 são as tensões superficiais dos dois componentes e $y$ é a tensão interfacial entre os polímeros formadores da mistura. 
Ao adicionar um agente compatibilizante em uma blenda, ele promove um decréscimo na tensão interfacial entre os componentes da blenda, resultando em um aumento da adesão entre as fases, que geralmente resulta em uma melhora das propriedades mecânicas da blenda, pois ao aumentar o trabalho de adesão entre os polímeros, as tensões necessárias para o aparecimento de quebra por fragmentação na interface são maiores.

\subsubsection{Estabilização da morfologia}

A estabilização da morfologia através da adição de agentes compatibilizantes é consequência de outros fatores analisados. Sabe-se que o agente compatibilizante diminui a tensão interfacial entre as fases da mistura, aumenta a adesão, diminui os efeitos da coalescência, assim, isto provoca a estabilização da morfologia.

A morfologia de uma mistura polimérica é resultante da quebra da fibra, retração da fibra e coalescência. Quando um compatibilizante é adicionado à mistura polimérica, a tensão interfacial diminui e o tempo de quebra ou retração aumenta, da mesma forma ele atrasa a coalescência, criando na superfície das gotas da fase dispersa uma camada de repulsão. Este aumento da desintegração das fibras e diminuição da coalescência resulta na estabilização da morfologia.

\subsubsection{Morfologia co-contínua}

A morfologia co-contínua mostra uma combinação única das características de ambos os componentes. Para a obtenção de blendas co-contínuas são utilizados dois métodos:

- O primeiro consiste em uma morfologia fora do equilíbrio produzida durante a mistura no estado fundido dos componentes da blenda, sendo a maior dificuldade obter uma mistura sub-micrométrica e preservar a estrutura durante o processamento. A adição de agentes compatibilizantes formado in situ ajuda no controle da coalescência e aumenta a adesão entre duas fases. Sugere-se que a morfologia co-contínua ocorre na inversão de fases [177] [178]; 
- O segundo método, as moléculas lineares de dois ou mais monômeros estão ligados covalentemente, assim dois polímeros que transportam grupos reativos complementares são misturados em conjunto e reagem a uma temperatura elevada, como mostra a Figura 60. Os polímeros com a cadeia principal, B, transportam os grupos reativos distribuídos aleatoriamente ao longo da cadeia principal, enquanto que nas cadeias $A$, os enxertos são funcionalizadas em apenas uma extremidade. Os materiais co-contínuos assim produzidos são estruturados na escala de dezenas de nanômetros e são, pelo menos em parte, cristalinos. O processo de produção, mistura reativa, proporciona ao material organização mincroscópica e estabilidade termodinâmica [179].

Figura 60- Princípio da mistura reativa entre dois polímeros.

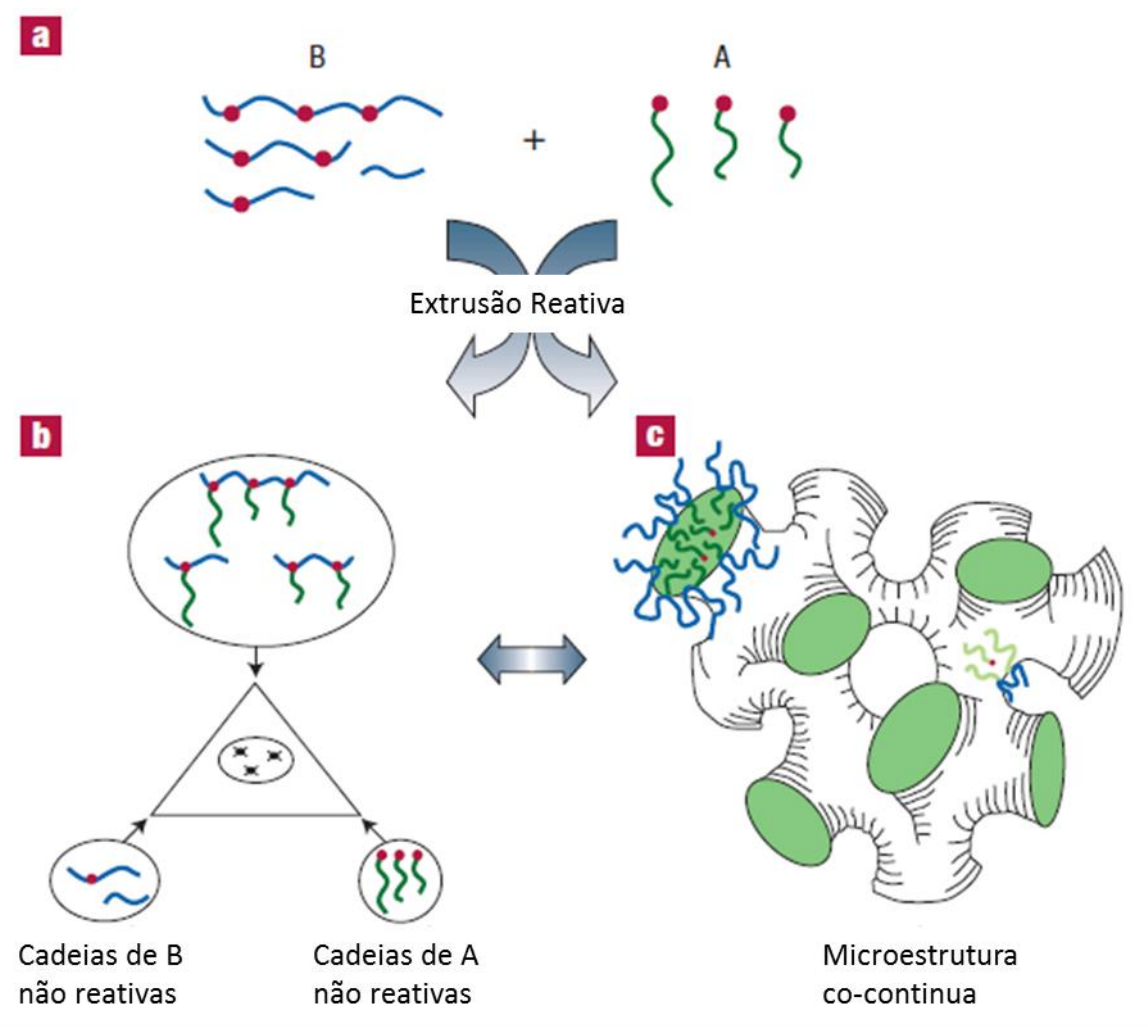

Fonte: Adaptado [179]

A estrutura de blendas co-contínuas permite melhores propriedades mecânicas, pois as duas fases podem contribuir para a resistência mecânica, logo as 
propriedades mecânicas das misturas co-contínuas, tais como resistência ao impacto e resistência à tracção, pode exceder os de qualquer componente da mistura [180].

Misturas de polímeros co-contínuas são usadas em embalagem de produtos sensíveis a umidade, como alimentos ou produtos farmacêuticos. Neste caso, uma fase é permeável à umidade, que pode conter um dessecante para remover a umidade a partir do interior destes pacotes, enquanto a outra fase proporciona resistência mecânica [167][181].

\subsubsection{Blendas com Amido}

Como visto no Capitulo 3, uma possibilidade de utilização do amido é misturálo com plastificantes, para que ocorra a desestruturação do grão, destruindo sua estrutura cristalina, formando, assim, o amido termoplástico.

Apesar do amido ser um material promissor, este possui uma aplicação limitada. Uma das maneiras de utilizar o amido para confecção de produtos é por composição do amido com outros polímeros, dando origem a blendas poliméricas [182] [183] [123] [184] [185].

Ao comparar as blendas com o desenvolvimento de novos materiais, estas apresentam custo mais baixo, além de conferirem grande diversidade à indústria de transformação de plástico. As blendas de TPS com outros polímeros têm como objetivo melhorar ou modificar as propriedades do TPS, além de reduzir o seu custo, uma vez que o amido é um dos materiais mais baratos disponíveis [184] [186][187].

O amido desestruturado tem sido misturado com outros polímeros advindos de petróleo, como o poli(álcool vinílico) e com a poli(caprolactona), formando o denominado amido complexado, através da interação das cadeias de amilose com aquelas do polímero petroquímico. Blendas de amido com outras substâncias, como o acetato de celulose, também são descritas na literatura [188].

Pode-se obter mistura de amido, também, com outros bioplásticos: como poli3-hidroxibutirato-co-3-hidroxivalerato, polilactatos e polibutileno succinato. Para melhoria de suas propriedades, amidos também tem sido modificados por métodos 
químicos, no sentido de se substituir parte das $-\mathrm{OH}$ das cadeias de amilose e amilopectina por grupos éter ou éster, produzindo os amidos modificados [188].

Atualmente há muitos trabalhos na literatura estudando o desenvolvimento de blendas a base de TPS. Parte dos trabalhos está relacionada a blendas de TPS com outros polímeros biodegradáveis (como o PCL, PLA e PHB) e outra parte está relacionada a blendas com polímeros convencionais a base de petróleo e não biodegradáveis (como o PEBD, PEAD, PP, PS. PA, PU e ABS) [65].

Um problema para o desenvolvimento de blendas contendo TPS está relacionado à baixa compatibilidade entre o amido e a maioria dos polímeros sintéticos disponíveis. Como a maioria dos polímeros sintéticos é hidrofóbica e o amido é hidrofílico, medidas devem ser tomadas para compatibilizar a blenda.

Recentemente verificou-se um aumento do interesse em blendas de amido e polímeros sintéticos não degradáveis, uma vez que a redução da quantidade de material de fonte não renovável já representa um grande avanço no desenvolvimento de novos materiais. Adicionalmente, diversos estudos têm demonstrado que as poliolefinas, por exemplo, quando fragmentadas podem ser metabolizadas, levando assim a sua completa biodegradação [189] [190]

Dentre os polímeros de maior interesse para formar blendas com o TPS se destaca o polietileno de baixa densidade (PEBD), que apresenta baixo custo, sendo um dos materiais mais empregados na produção de filmes para embalagens, filmes para agricultura e outras aplicações onde características tais como biodegradabilidade e maior conteúdo de material renovável são desejáveis [191]. Alguns estudos destacam a utilização de agentes compatibilizantes em blendas de TPS e PE, tais como o poli(etileno-g-anidrido maleico) (PE-g-MA) [192] [193], poli(etileno-co-vinil álcool) (EVOH) [194], poli(etileno-co-ácido acrílico) (EAA), poli(etileno-co-metacrilato de glicidila) (PEGMA) [195] [196] [70].

Uma alternativa para a blenda é adicionar compatibilizantes esterificantes que reagem com as hidroxilas $(-\mathrm{OH})$ do amido reduzindo, assim, seu caráter hidrofílico. Dentre os compatibilizantes com estas características podemos citar ácidos carboxílicos como o ácido cítrico e ácido ascórbico. Com a esterificação das hidroxilas promovidas por estes 
ácidos, há uma redução nas forças intermoleculares, melhorando a compatibilidade da blenda.

Ning et al. [78] descreveram o uso do ácido cítrico na compatibilização do TPS com o polietileno linear de baixa densidade, empregando um processo de extrusão em um único estágio. Esses autores observaram uma melhora considerável nas propriedades dos materiais produzidos, com relação ao material processado na ausência de ácido cítrico.

Além disso, o ácido cítrico pode promover a hidrólise da cadeia, reduzindo a massa molar e provocando assim uma redução na viscosidade. Com uma viscosidade mais baixa pode ocorrer uma redução na tensão interfacial entre o TPS e o outro polímero, melhorando, portanto, a compatibilidade da blenda [197].

Recentemente tem-se utilizado a compatibilização reativa, a qual ocorre durante o processamento em extrusoras, e os resultados obtidos são promissores [192][194][195][196][70][198].

\subsection{PARTE EXPERIMENTAL}

\subsubsection{Materiais}

Foram utilizados o Amide ${ }^{\circledR} 3001$, que é um amido de milho da Ingredion, água destilada, glicerol (massa molecular = 92,09 u), e os ácidos carboxílicos:

- cítrico anidro (massa molecular $=192,13 \mathrm{u}$ ),

- málico DL (massa molecular $=134,09 \mathrm{u}$ ) e

- tartárico anidro P.A (massa molecular = 150,09 u).

Todos foram obtidos na Casa Americana de artigos para Laboratórios.

O PP utilizado foi o RP347 que é um copolímero (PP-g-PE). Como este material é muito utilizado em embalagens, foi possível obtê-lo na forma de resíduo industrial, da Eng Plast Indústria e Comércio de Artigos Plásticos. Também foi utilizado o Polybond 3200 da Chemtura que é um PP-g-AM, e possui 1\% em massa de anidrido maleico. Escolheu-se o PP reciclado pois não há sentido em pegar um material virgem 
com excelentes propriedades e modifica-lo de modo a manter ou ocorrer uma queda em suas propriedades mecânicas.

\subsubsection{Processamento}

\subsubsection{Processamento do TPS}

Primeiramente o amido foi seco em estufa a vácuo por 48 horas, a $110^{\circ} \mathrm{C}$. De acordo com os resultados obtidos no Capítulo 3, foi utilizado 20\% de água, 30\% de glicerol e $2 \%$ dos ácidos cítrico, tartárico e málico. O ácido adípico não foi utilizado por apresentar aumento nos valores de torque durante seu processamento. Os teores de água e ácidos foram calculados em relação a massa de amido.

As misturas já pesadas foram misturadas com auxílio de um misturador IKA ${ }^{\circledR}$ Werke Eurostar a 1500 rpm por 20 minutos para garantir a homogeneidade da mistura. As misturas foram seladas e armazenadas em estufa a $25^{\circ} \mathrm{C}$.

Passados pelo menos 24h, essas misturas foram processadas em uma extrusora dupla rosca acoplada a um reômetro de torque HAAKE e auxilio de bomba de vácuo para retirada de voláteis. A rampa de temperatura utilizada foi de 100 a $125^{\circ} \mathrm{C}$ e foi utilizada na rosca $100 \mathrm{rpm}$.

Para o resfriamento utilizou-se sistema de esteira com ar comprimido, SCHULZ, modelo Rothy 80851 como mostra a Figura 61. Em seguida o material foi peletizado, em um peletizador Primotécnica modelo PGS50.

Figura 61 - Esquema do Processamento do TPS realizado em extrusora, resfriado com ar comprimido e peletizado.

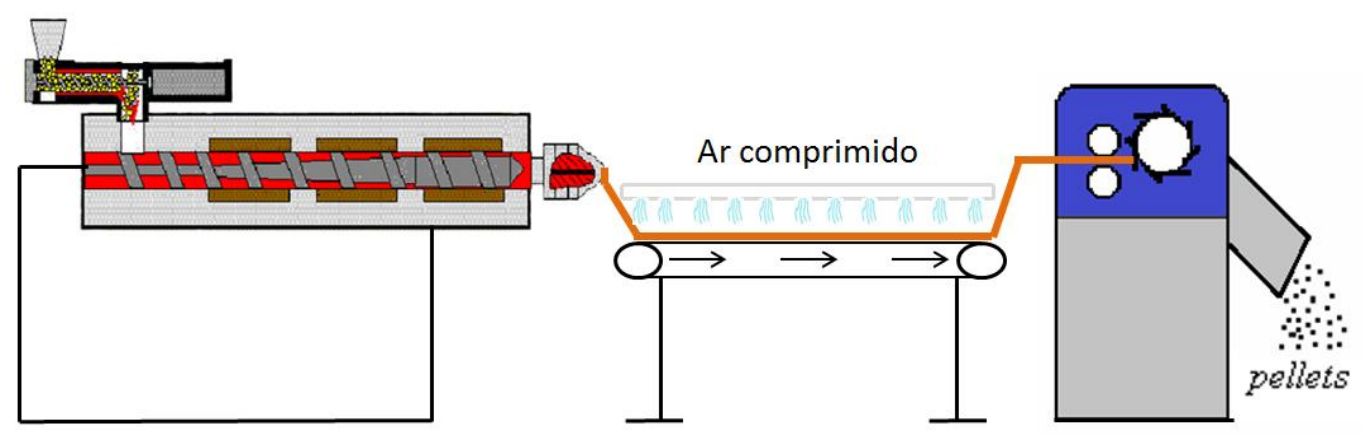


Os corpos de prova foram moldados por injeção, utilizando-se a máquina injetora Demag Ergotech (diâmetro de rosca de $25 \mathrm{~mm}$ e L/D 20). O perfil de temperatura utilizado para o TPS puro foi de 100 a $120^{\circ} \mathrm{C}$ e para as blendas foi de 155 a $160^{\circ} \mathrm{C}$.

\subsubsection{Processamento da Blenda PP/TPS}

Primeiramente o PP (RP347, PP-g-PE) doado foi moído em um moinho de facas, como mostra a Figura 62. O PP moído foi colocado em estufa a $80^{\circ} \mathrm{C}$ por $24 \mathrm{~h}$.

Figura 62 - PP doado na forma de "galhos" e após ser moído.

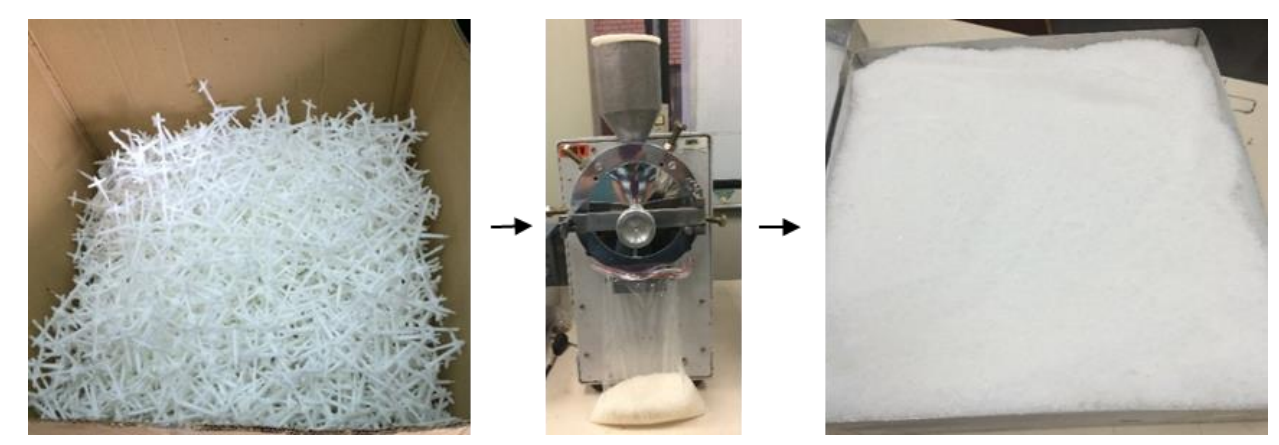

O PP moído foi processado com o TPS com e sem polybond (10\%) nas blendas: 70/30, 60/40 e 50/50. Novamente foi utilizada uma extrusora dupla rosca acoplada a um reômetro de torque HAAKE, a $160^{\circ} \mathrm{C}$ e $100 \mathrm{rpm}$ (Figura 61).

A confecção dos corpos de prova foi feita em uma injetora Demag Ergotech PRO 35-115, com diâmetro de rosca de $25 \mathrm{~mm}$ e L/D de 20. Os corpos de prova seguem a norma ASTM D638-10.

\subsubsection{Caracterização}

\subsubsection{Vibracional de Absorção no infravermelho com transformada de Fourier} (FTIR)

As amostras injetadas foram raspadas e o ensaio foi realizado no mesmo equipamento descrito no item 3.3.3.2. 


\subsubsection{Difração de Raios X (DRX)}

Os materiais injetados foram analisados através de um difratômetro da marca Bruker, modelo D8 Advance Da Vinci localizado no Departamento de Geologia da Universidade de São Paulo. Utilizou-se o cobre como fonte geradora de raios- $x$ (comprimento de onda $1,5418 \AA$ ) $A$ varredura foi de $2 \theta$ foi realizada na faixa de 2 a $60^{\circ}$, com tempo de varredura de $0,2 \mathrm{~s}$, abertura do detector de $2,942^{\circ}, 40 \mathrm{kV}$ e $40 \mu \mathrm{A}$.

\subsubsection{Reometria Capilar}

As análises de reometria capilar foram realizadas em um reômetro capilar marca Instron CEAST, modelo SR20 localizado na Universidade Federal do ABC. A viscosidade foi medida a temperatura de $160^{\circ} \mathrm{C}$, que corresponde a temperatura de processamento dos materiais, utilizando um capilar com diâmetro de $1 \mathrm{~mm}$ e comprimento de $20 \mathrm{~mm}$ com taxa de cisalhamento variando de 500 a $15.000 \mathrm{~s}^{-1}$, valores tipicamente encontrados em processos de extrusão e injeção de polímeros. Os dados de viscosidade foram corrigidos aplicando as correções de Bagley.

\subsubsection{Microscopia Eletrônica de Varredura (MEV)}

As análises foram realizadas da mesma forma citada no item 4.3.2.5. Em algumas amostras foi realizada a extração da fase TPS. Essa extração foi feita com álcool metílico por 3 dias.

\subsubsection{Propriedades Mecânicas: Ensaio de Tração}

Os ensaios de tração foram realizados em duas etapas: na primeira foi utilizada uma velocidade de $1 \mathrm{~mm} / \mathrm{min}$, até $1 \%$ de deformação, para determinação do módulo de elasticidade. Depois se utilizou a velocidade de $10 \mathrm{~mm} / \mathrm{min}$ até a ruptura. Foram realizadas cerca de oito medidas para cada tipo de amostra.

Foi utilizada uma Máquina Universal de Ensaios Instron 3369, com célula de carga de $50 \mathrm{kN}$ e taxa de deformação de $50 \mathrm{~mm} / \mathrm{min}$, conforme a norma ASTM D63810 [91]. Localizado no Laboratório de Ensaios Poliméricos na Universidade Federal do $A B C$. 


\subsection{RESULTADOS E DISCUSSÕES}

\subsubsection{Blendas PP/TPS}

\subsubsection{FTIR}

A Figura 63 apresenta o FTIR das amostras de PP reciclado e PP reciclado com anidrido maleico. Notam-se as bandas de absorção típicas de ligações $\mathrm{C}-\mathrm{H}$ presentes no polipropileno, ou seja, estiramento de grupos $\mathrm{CH} / \mathrm{CH}_{2} / \mathrm{CH}_{3}$ entre 2850 e $2980 \mathrm{~cm}^{-1}$, deformação angular de grupos $\mathrm{CH} 3 \mathrm{em} 1354 \mathrm{e} 1460 \mathrm{~cm}^{-1}$, estiramento de ligações C-C em $1167 \mathrm{~cm}^{-1}$ e deformação angular dos grupos $\mathrm{C}-\mathrm{H}$ em $890 \mathrm{~cm}^{-1}$. Notase ainda bandas de absorção em 2923 e $2850 \mathrm{~cm}^{-1}, 1790$ e $1720 \mathrm{~cm}^{-1}, 1467 \mathrm{~cm}^{-1}$, $1374 \mathrm{~cm}^{-1}$ e $720 \mathrm{~cm}^{-1}$ referente ao polietileno. As bandas de absorção em 1790 e 1860 $\mathrm{cm}^{-1}$,podem ser associadas ao estiramento simétrico e assimétrico, respectivamente, da carbonila do anidrido, já a banda de absorção em 1710 e em 1779 cm$^{-1}$ normalmente é associada à carbonila do ácido maleico [199][200].

A Figura 64 mostra os espectros FTIR das blendas PP/TPS-SA (a), PP/TPSAC (b), PP/TPS-AM (c) e PP/TPS-AT (d). Analisando as blendas nota-se que ao se adicionar o TPS, os picos característicos de PP se mantém. Comparando as blendas com ácidos e sem ácidos nota-se um pico em $1720 \mathrm{~cm}^{-1}$ referente à esterificação do TPS.

Figura 63 - Curvas de FTIR das amostras de PP reciclado e PP reciclado com anidrido maleico.

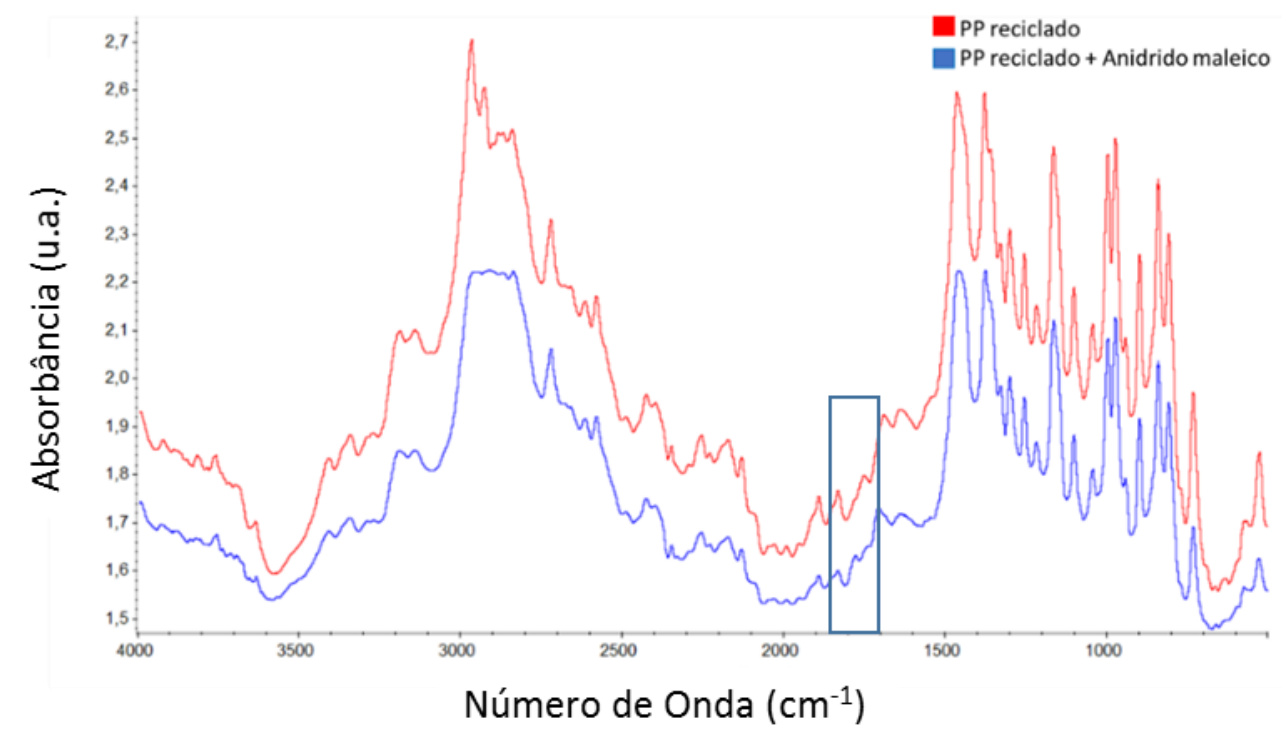


Figura 64 - Curvas de FTIR das blendas 70/30 de PP/TPS-SA e PP/TPS-AC.

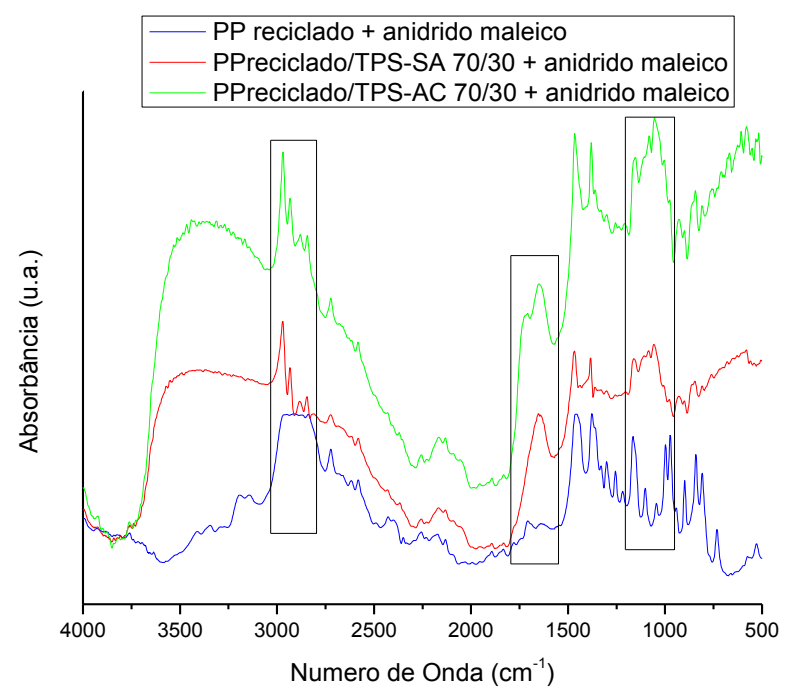

\subsubsection{Difração de Raios X (DRX)}

A Figura 65 mostra o $\mathrm{DRX}$ do $\mathrm{PP}$, do PP reciclado e do PP com adição de anidrido maleico. Pode-se observar que o PP reciclado não sofreu alteração na estrutura cristalina, quando comparado ao PP não reciclado. Entretanto, ao se adicionar anidrido maleico ao PP observa-se a presença de novos picos de difração em $2 \theta=33,38,47$ e 53ำ em relação ao $\mathrm{PP}$.

Figura 65 - Curvas de DRX das amostras de PP.

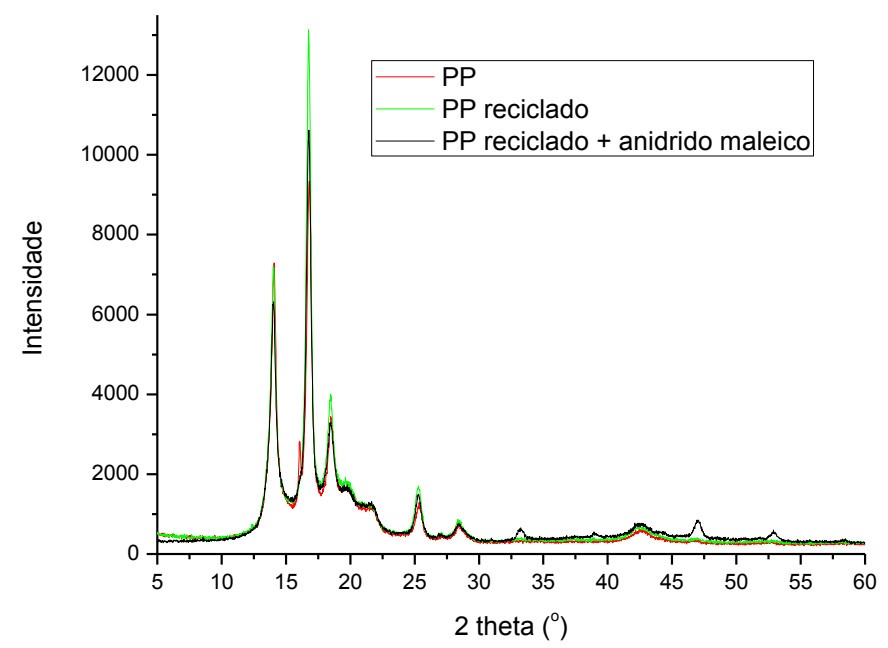

A Figura 66 mostra o DRX das amostras do TPS puro e a Tabela 18 mostra os picos de difração encontrados, e suas respectivas referências. Como o 
processamento das amostras foi diferente do empregado no Capítulo 3, pode-se notar uma pequena diferença em relação à Tabela 15. Comparando as amostras pode-se notar que as amostra AM e AT possuem picos de difração referentes às estruturas $V_{A}$ menos intensos do que as demais. Em todas as amostras predominam estruturas $\mathrm{V}_{\mathrm{H}}$, que são mais estáveis do que as demais estruturas cristalinas encontradas em amido.

Figura 66 - Curvas de DRX dos TPS puros.

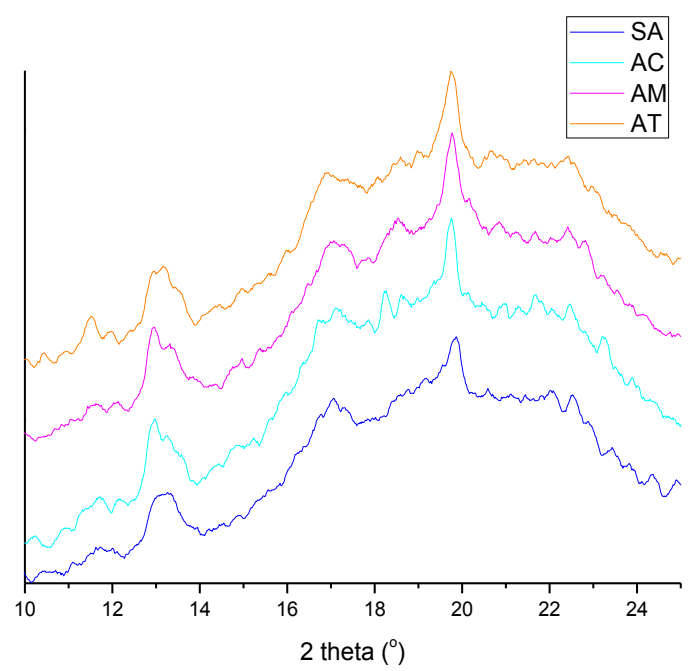

Tabela 18 - Picos encontrados no DRX das amostras de TPS.

\begin{tabular}{c|cccc|c}
\hline $\begin{array}{c}\text { Tipo de } \\
\text { Cristal }\end{array}$ & SA2 & AC2 & AM2 & AT2 & $\begin{array}{c}\text { Picos de Referência } \\
\text { (Literatura) }\end{array}$ \\
\cline { 2 - 6 } & $\mathbf{2}$ theta $\left(^{\circ}\right)$ & $\mathbf{2}$ theta $\left(^{\circ}\right)$ & $\mathbf{2}$ theta $\left(^{\circ}\right)$ & 2 theta $\left(^{\circ}\right)$ & 2 theta $\left(^{\circ}\right)$ \\
\hline$E_{H}$ & 12 & 12 & 12 & 12 & 12 \\
\hline$V_{H}$ & 13 & 12,9 & 12,9 & 13 & 12,9 \\
\hline$V_{H}$ & 13,3 & 13,3 & 13,3 & 13,3 & 13,3 \\
\hline$V_{A}$ & 13,6 & 13,6 & 13,6 & 13,6 & 13,6 \\
\hline$V_{H}$ & 14,9 & 14,9 & 14,9 & 14,9 & 14,9 \\
\hline$V_{A}$ & 15,7 & 15,8 & - & - & 15,8 \\
\hline$V_{H}$ & 17 & 17 & 17 & 17 & 17 \\
\hline$E_{H}$ & 18,5 & 18,5 & 18,5 & 18,5 & 18,4 \\
\hline$V_{H}$ & 18,9 & 18,9 & 18,9 & 18,9 & 18,8 \\
\hline$V_{A}$ & 19,5 & 19,4 & - & - & 19,4 \\
\hline$V_{H}$ & 19,8 & 19,8 & 19,8 & 19,8 & 19,8 \\
\hline$V_{A}$ & 20,7 & 20,9 & 20,8 & 20,8 & 20,8 \\
\hline$V_{H}$ & 22 & 22,2 & 22,2 & 22,2 & 22,2 \\
\hline$V_{H}$ & 22,5 & 22,5 & 22,5 & 22,5 & 22,6 \\
\hline
\end{tabular}


Analisando as blendas e comparando-as com o PP puro e o TPS puro (Figura 67) pode-se notar que nas blendas, conforme o teor de TPS aumenta há uma queda nos valores de intensidade dos picos de difração do PP, o que era esperado pois o conforme aumenta o teor de TPS, o teor de PP diminui.

Figura 67 - Curvas de DRX das blendas de PP/TPS sem ácido (a) e com ácido cítrico (b).

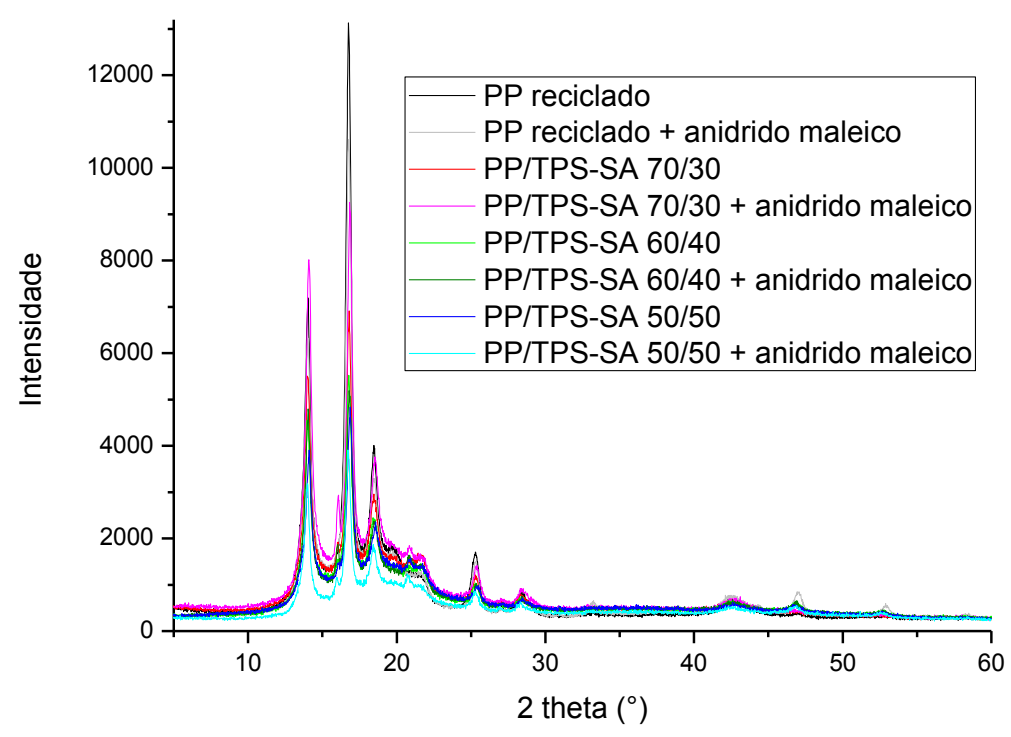

(a)

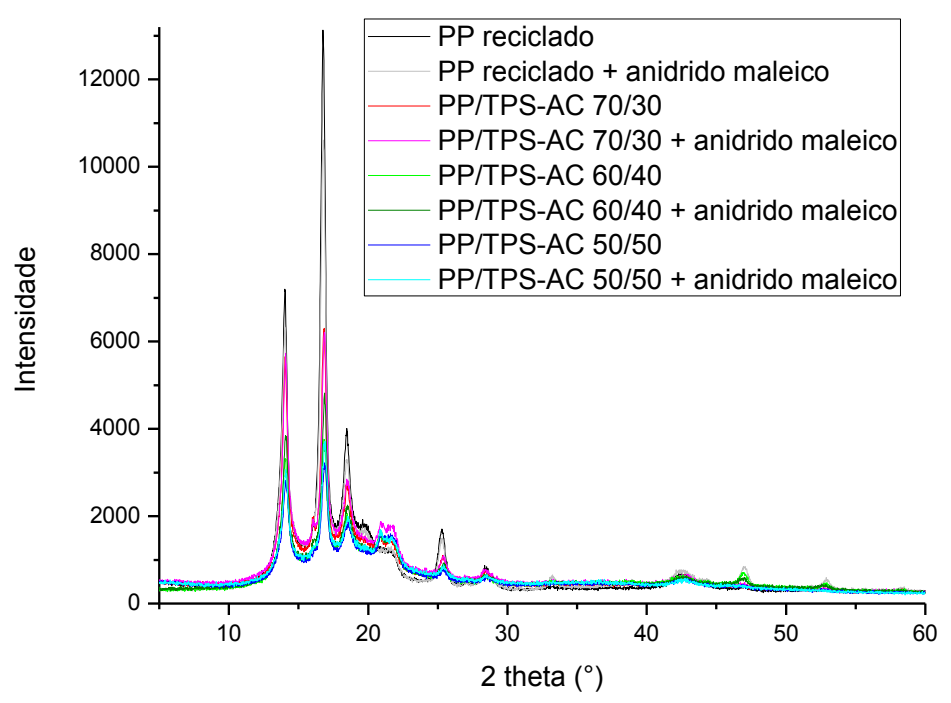

(b) 


\subsubsection{Reometria Capilar}

A razão de viscosidade entre as fases dispersa e matriz é uma propriedade reológica que afeta a morfologia de misturas poliméricas, os dados para calcular essa propriedade foram obtidos no gráfico da Figura 68 e reportados na Tabela 19 e

Tabela 20. A razão de viscosidade $(\lambda)$ foi obtida para valores de taxas de cisalhamento aos quais as misturas foram submetidas durante o processo de extrusão $\left(1.000 \mathrm{~s}^{-1}\right)$ e durante o processo de injeção $\left(10.000 \mathrm{~s}^{-1}\right)$.

Analisando apenas as viscosidades dos TPS com diferentes ácidos, nota-se que o TPS sem ácido é o mais viscoso, o que era esperado, pois como citado no planejamento estatístico, quando não se tem a presença de ácido o processamento torna-se mais difícil. Já o TPS com ácido cítrico possui o menor valor de viscosidade, o que corrobora com os resultados do DSC.

Figura 68- Curvas da viscosidade em função da taxa de cisalhamento à $160^{\circ} \mathrm{C}$.

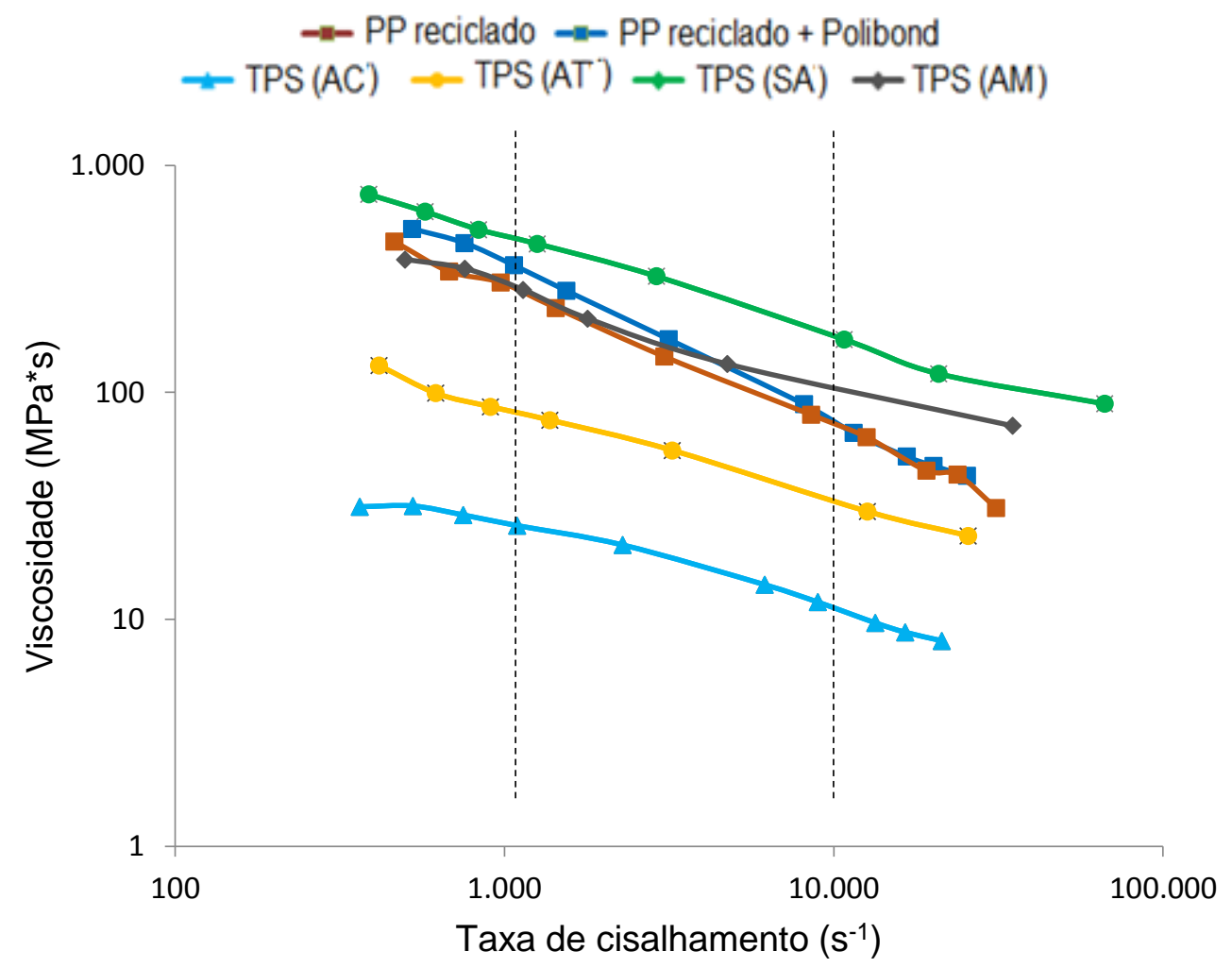


Todas as composições apresentaram razão de viscosidade fora da faixa citada por $\mathrm{Wu}$ [173], ou seja, caso a morfologia predominante seja a de gotas de fase dispersa, esta não deve ser "fina", ou ainda, estas podem possuir morfologia predominante co-contínua.

Tabela 19 - Viscosidade dos componentes da blenda e razão de viscosidade (fase matriz: PP reciclado) para taxa de cisalhamento dos processos extrusão $\left(1000 \mathrm{~s}^{-1}\right)$ e injeção $\left(10000 \mathrm{~s}^{-1}\right)$.

\begin{tabular}{ccc|cc}
\hline Composição & \multicolumn{2}{c|}{ em 1000 s $^{-1}$} & \multicolumn{2}{c}{ em 10000 s $^{-1}$} \\
\cline { 2 - 5 } & $\begin{array}{c}\text { Viscosidade } \\
(\mathbf{P a . s})\end{array}$ & $\begin{array}{c}\text { Razão de } \\
\text { Viscosidade } \\
(\boldsymbol{\Lambda})\end{array}$ & $\begin{array}{c}\text { Razão de } \\
\text { Viscosidade } \\
(\mathbf{P a . s})\end{array}$ & $\begin{array}{c}\text { Viscosidade } \\
(\boldsymbol{\lambda})\end{array}$ \\
\hline PP reciclado & 300 & - & 73 & - \\
\hline TPS (AC) & 26 & 0,08 & 11 & 0,15 \\
\hline TPS (AT) & 84 & 0,28 & 36 & 0,49 \\
\hline TPS (SA) & 462 & 1,54 & 182 & 2,49 \\
\hline TPS (MA) & 296 & 0,99 & 123 & 1,68 \\
\hline
\end{tabular}

Tabela 20 - Viscosidade dos componentes da blenda e razão de viscosidade (fase matriz: PP reciclado + anidrido maleico) para taxa de cisalhamento dos processos extrusão $\left(1000 \mathrm{~s}^{-1}\right) \mathrm{e}$ injeção (10000 s-1).

\begin{tabular}{|c|c|c|c|c|}
\hline \multirow[b]{2}{*}{ Composição } & \multicolumn{2}{|c|}{ em $1000 \mathrm{~s}^{-1}$} & \multicolumn{2}{|c|}{ em $10000 \mathrm{~s}^{-1}$} \\
\hline & $\begin{array}{c}\text { Viscosidade } \\
\text { (Pa.s) }\end{array}$ & $\begin{array}{c}\text { Razão de } \\
\text { Viscosidade } \\
(\lambda)\end{array}$ & $\begin{array}{c}\text { Viscosidade } \\
\text { (Pa.s) }\end{array}$ & $\begin{array}{c}\text { Razão de } \\
\text { Viscosidade } \\
(\lambda)\end{array}$ \\
\hline $\begin{array}{l}\text { PP reciclado + } \\
\text { anidrido maleico }\end{array}$ & 363 & 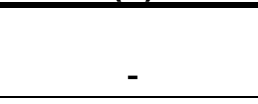 & 75 & $x_{2}$ \\
\hline TPS (AC) & 26 & 0,07 & 11 & 0,15 \\
\hline TPS (AT) & 84 & 0,23 & 36 & 0,48 \\
\hline TPS (SA) & 462 & 1,27 & 182 & 2,43 \\
\hline TPS (MA) & 296 & 0,81 & 123 & 1,64 \\
\hline
\end{tabular}

\subsubsection{Microscopia Eletrônica de Varredura (MEV)}

A Figura 69 mostra a micrografia obtida do PP reciclado e do PP reciclado com anidrido maleico. Esta figura foi colocada apenas para efeito de comparação entre amostras com e sem os ácidos carboxílicos. 
Figura 69 - MEV do PP reciclado (a) e do PP reciclado com anidrido maleico(b).

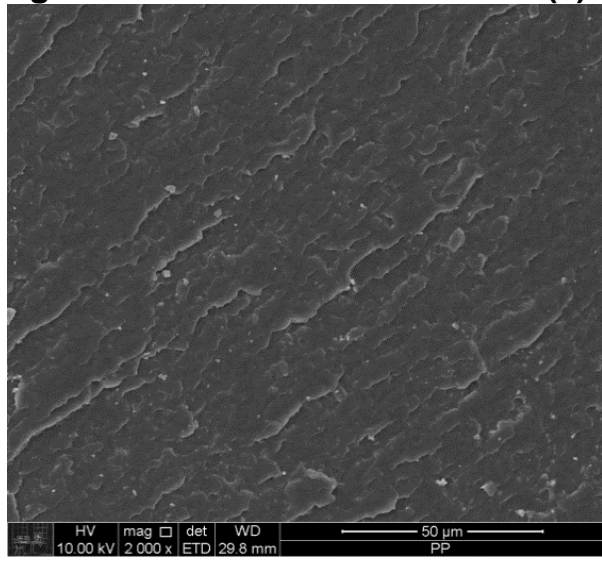

(a)

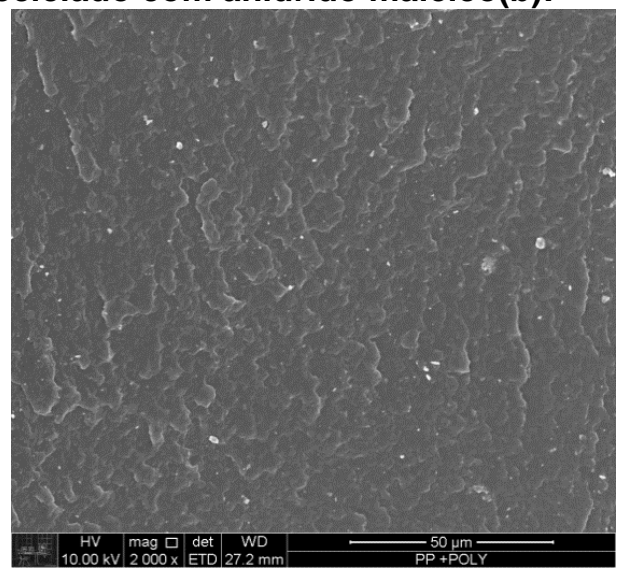

(b)

A Figura 70 mostra as micrografias das blendas de PP/TPS-SA. Observa-se que ao adicionar anidrido maleico em todas as composições de PP/TPS-SA ocorre uma queda nos domínios da fase dispersa, isso pode ser confirmado após o ataque a uma das fases. As micrografias indicam que todas as composições estudadas possuem morfologia predominantemente co-contínua, e alguns domínios de fase dispersa possuem formato de gotas. Entretanto, como descrito acima, esta morfologia precisa ser confirmada por extração da fase dispersa. Esta morfologia depende de parâmetros como a viscosidade dos componentes da blenda, o processamento e a composição. Nas blendas sem ácidos é notável uma melhor homogeneização ao acrescentar o PP-g-MA. Nota-se também que ao aumentar o teor de amido, aparentemente a quantidade de fissuras aumenta, o que pode indicar uma compatibilização fraca.

A Figura 71 mostra as micrografias das blendas de PP/TPS-AC. Em todas as amostras ao adicionar o anidrido maleico nota-se uma melhor compatibilização das fases. Mas, comparando com as amostras sem ácido pode-se ver que a mudança não é tão significativa.

A Figura 72 mostra as micrografias das blendas de PP/TPS-AM e a Figura 73 mostra as micrografias das blendas de PP/TPS-AT. Nota-se que em todas as amostras não há diferença na morfologia das blendas com e sem anidrido maleico, isso pode ocorrer devido aos ácidos málico e tartárico poderem atuar como compatibilizantes para o TPS e o PP. 
Figura 70 - MEV das blendas de PP/TPS-SA 70/30 (a), 70/30 com anidrido maleico (b), 60/40 (c), $60 / 40$ com anidrido maleico (d), 50/50 (e) e 50/50 com anidrido maleico (f).

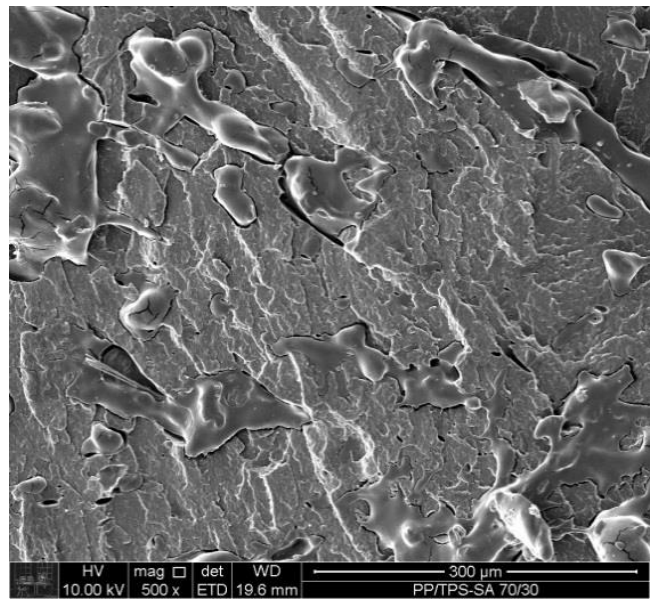

(a)

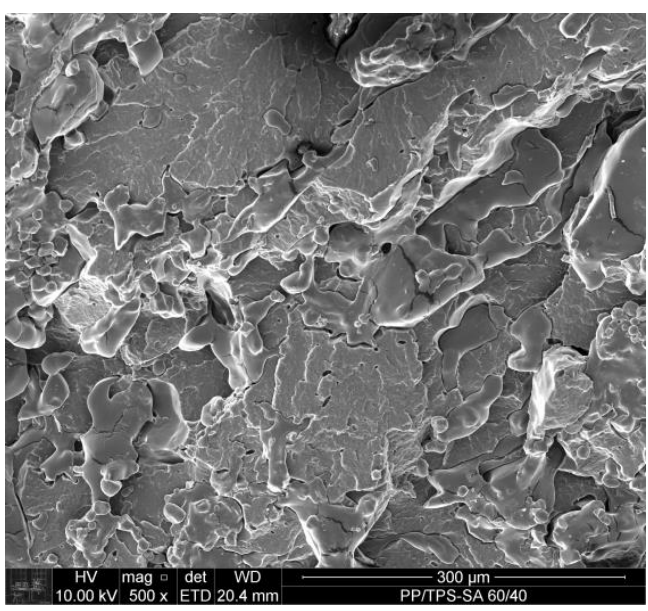

(c)

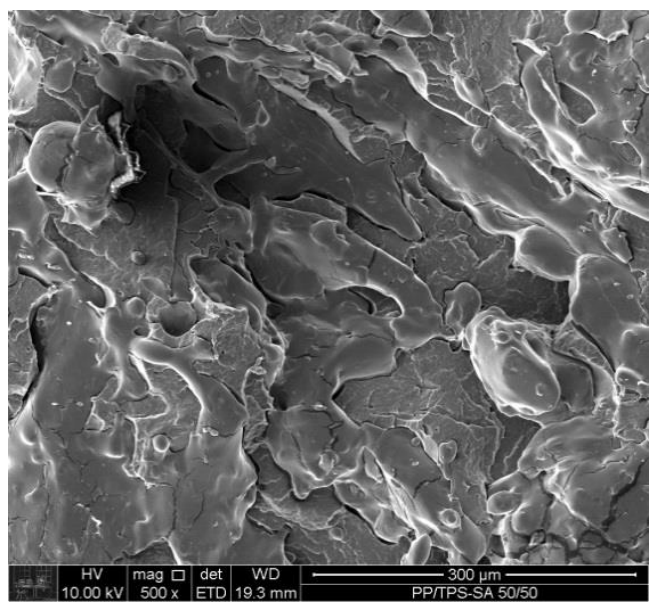

(e)

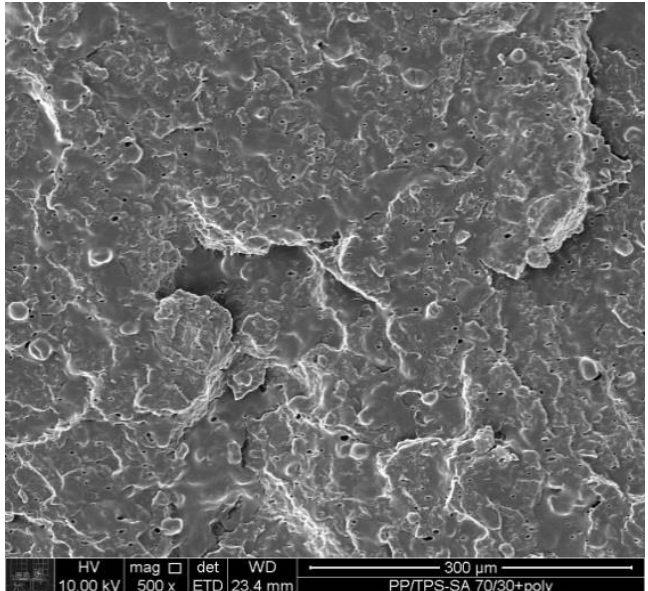

(b)

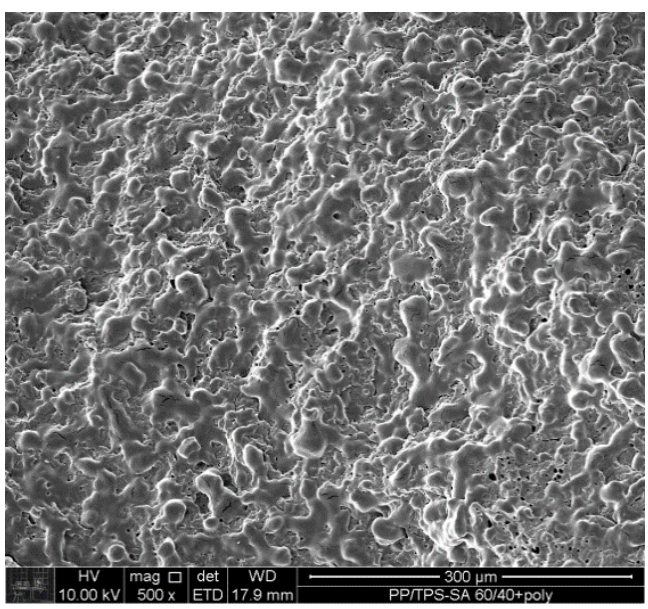

(d)

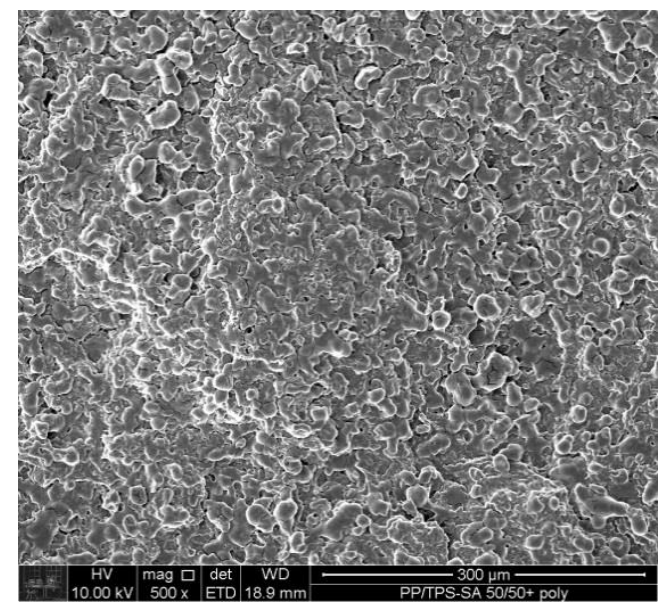

(f) 
Figura 71 - MEV das blendas de PP/TPS-AC 70/30 (a), 70/30 com anidrido maleico (b), 60/40 (c), $60 / 40$ com anidrido maleico (d), 50/50 (e) e 50/50 com anidrido maleico (f).

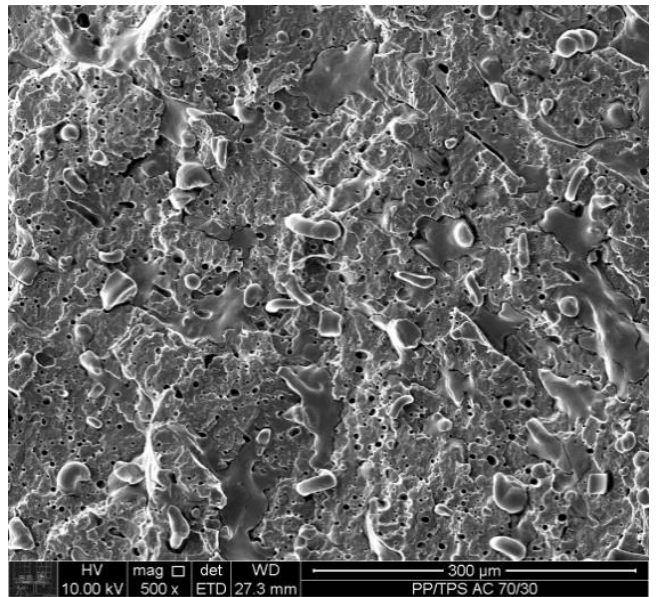

(a)

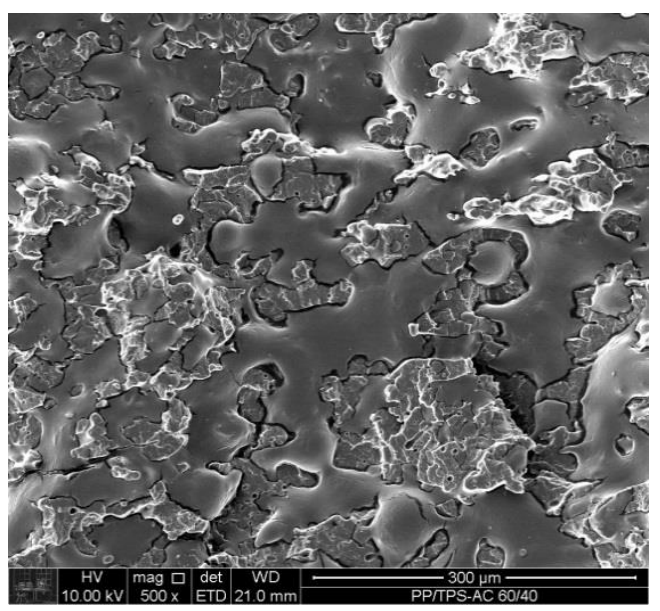

(c)

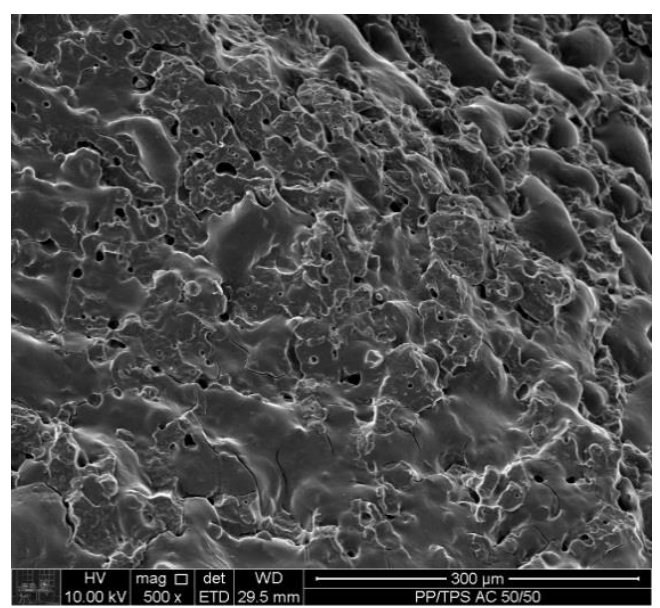

(e)

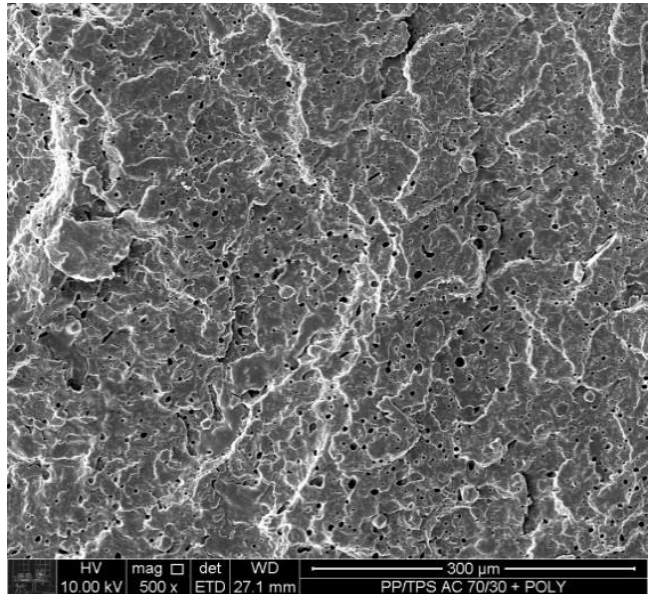

(b)

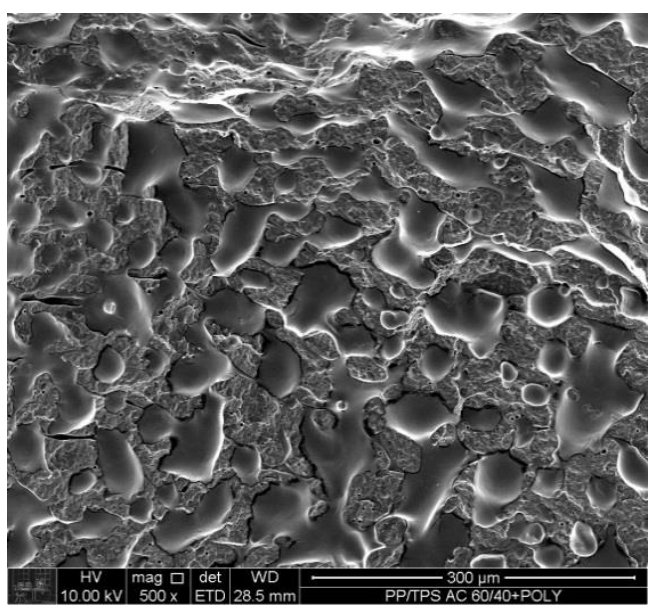

(d)

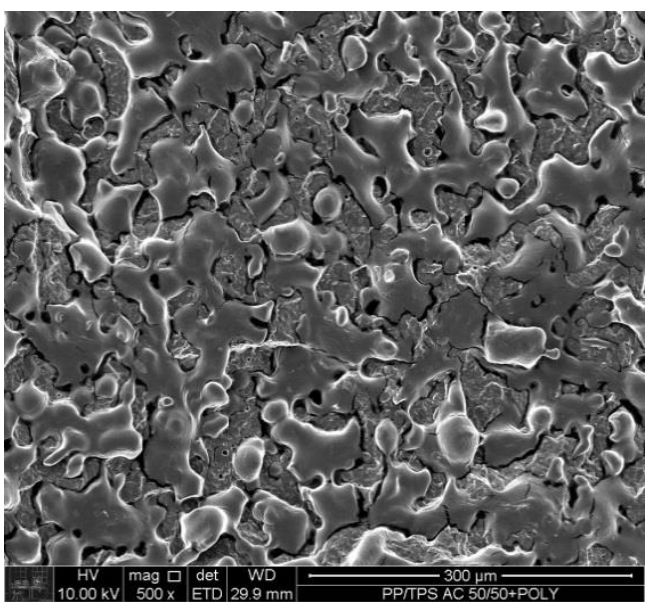

(f) 
Figura 72 - MEV das blendas de PP/TPS-AM 70/30 (a), 70/30 com anidrido maleico (b), 60/40 (c), $60 / 40$ com anidrido maleico (d), 50/50 (e) e 50/50 com anidrido maleico (f).

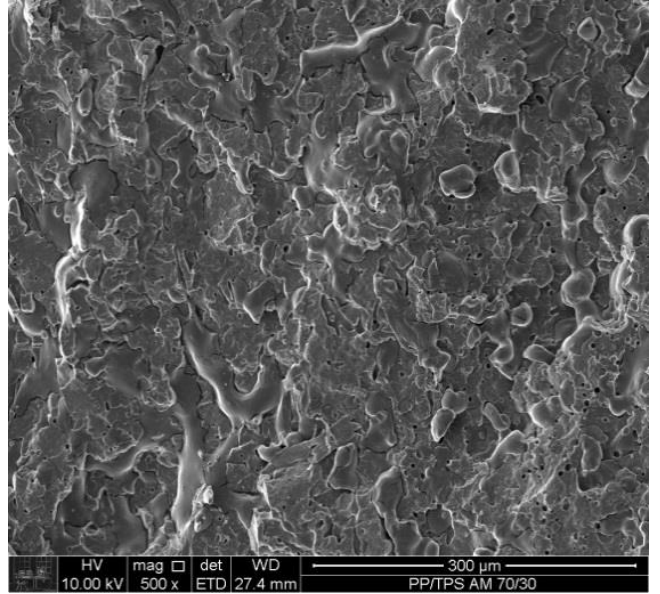

(a)

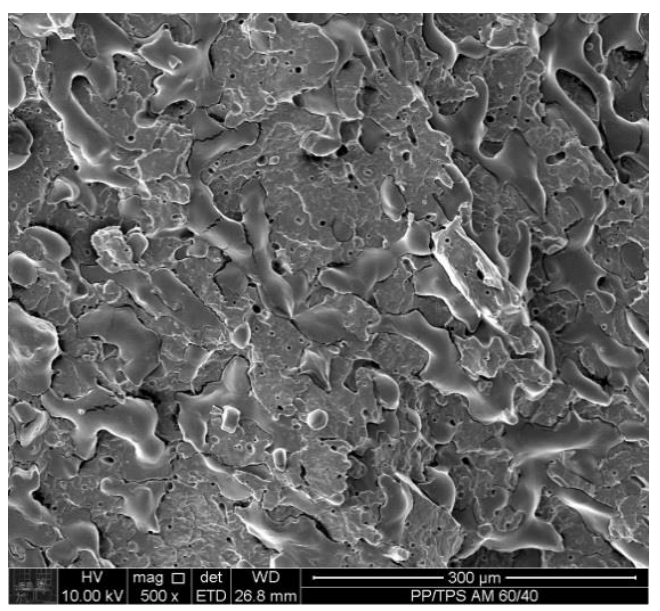

(c)

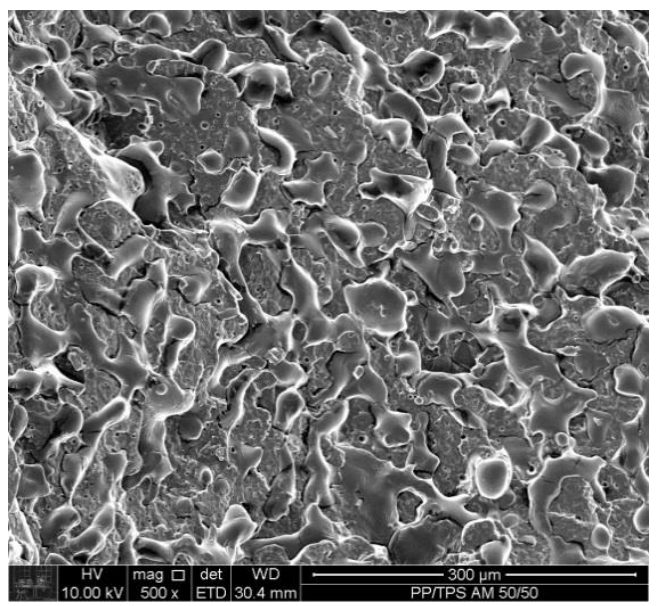

(e)

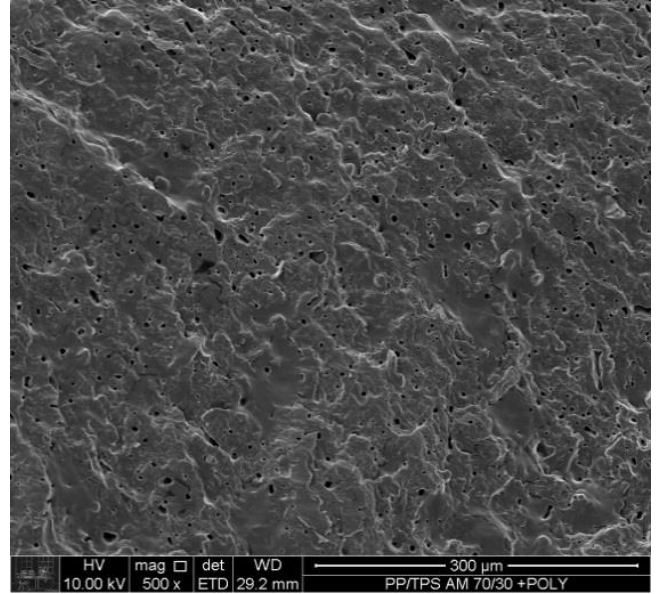

(b)

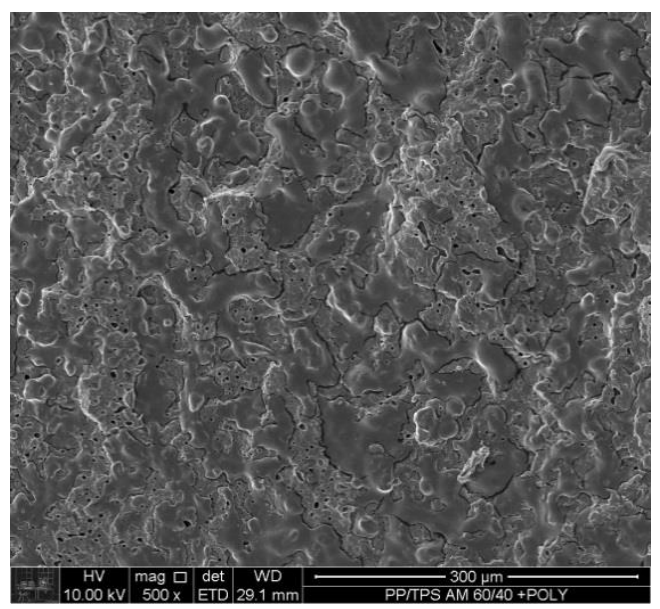

(d)

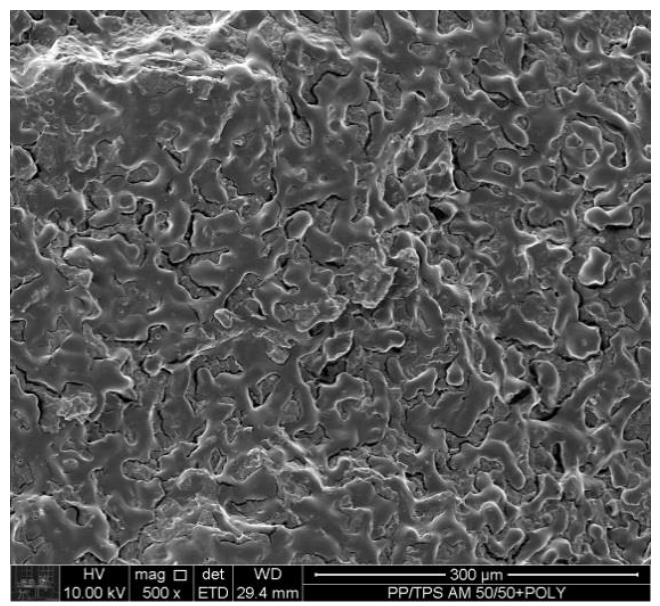

(f) 
Figura 73 - MEV das blendas de PP/TPS-AT 70/30 (a), 70/30 com anidrido maleico (b), 60/40 (c), $60 / 40$ com anidrido maleico (d), 50/50 (e) e 50/50 com anidrido maleico (f).

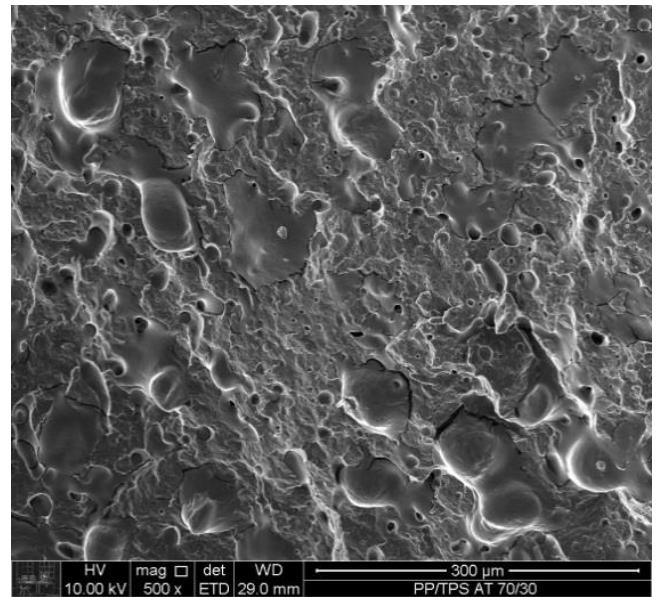

(a)

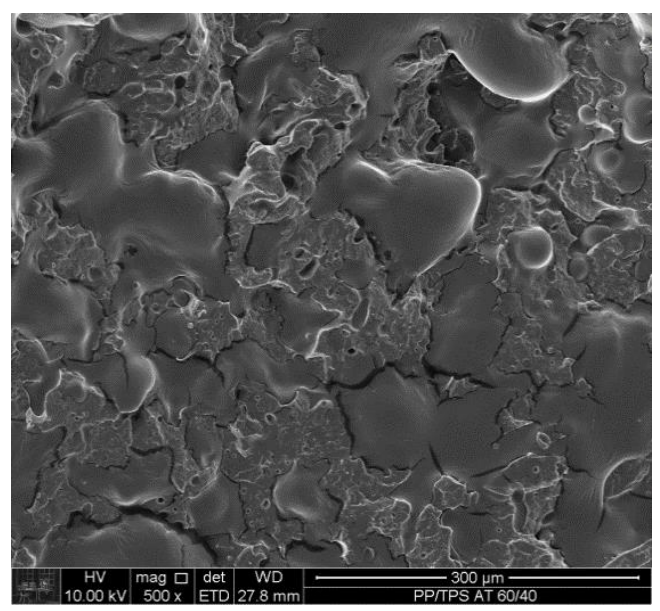

(c)

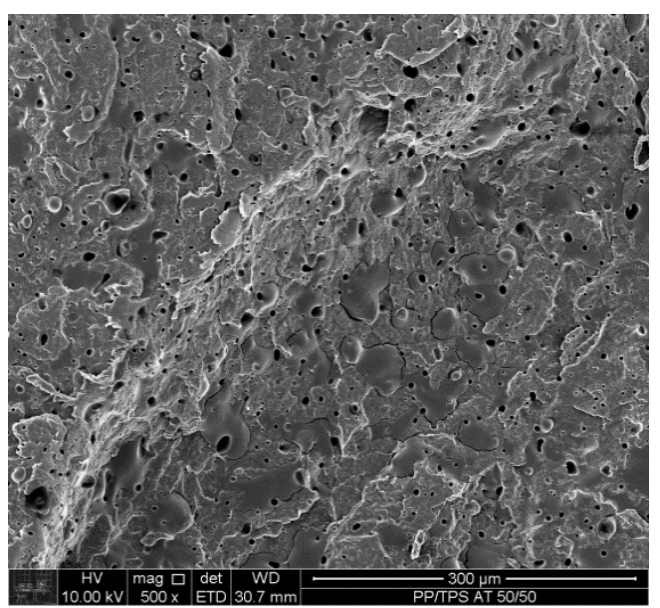

(e)

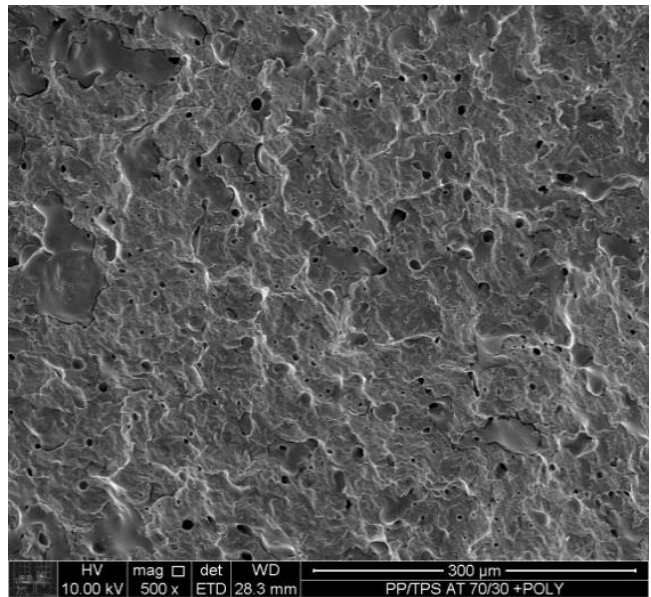

(b)

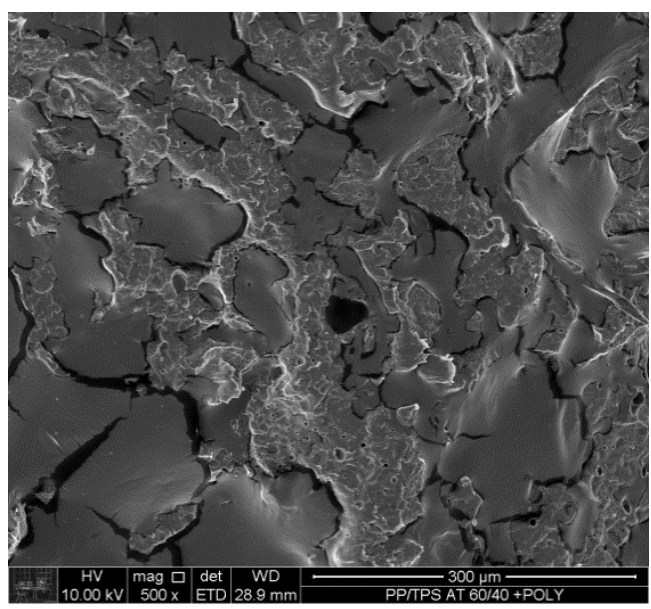

(d)

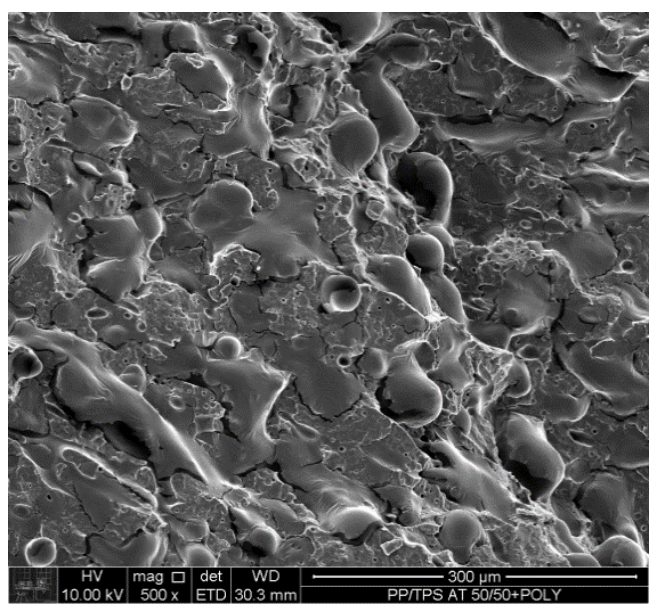

(f) 
A Figura 74 mostra o MEV da blenda de PP/TPS-SA 50/50 após extração do TPS. Observando a figura pode-se confirmar que a morfologia é co-contínua.

Figura 74 - MEV da blenda de PP/TPS-SA 50/50 após extração do TPS.

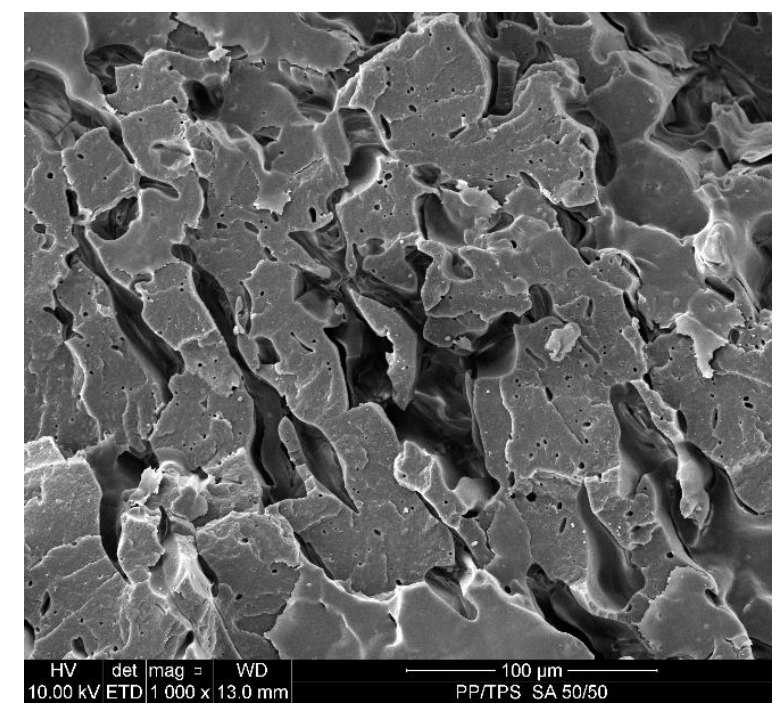

A Figura 75 mostra o MEV das blendas de PP/TPS-AC após extração do TPS: 50/50 (a), 50/50 com anidrido maleico (b), 70/30 (c), 70/30 com anidrido maleico (d). Desta forma, pode-se confirmar que com a adição de anidrido maleico na proporção 70/30 ocorre uma queda no tamanho dos domínios de TPS.

O mesmo não ocorre para as blendas PP/TPS-AT, que podem ser vistas na Figura 76. A morfologia das blendas 50/50 com e sem anidrido maleico e 70/30 com e sem anidrido maleico mostra-se co-continua, mas não se nota diferença ao se adicionar anidrido maleico.

A Figura 77 mostra MEV das blendas de PP/TPS-AM após extração do TPS 50/50 com anidrido maleico (a), 70/30 com anidrido maleico (b). Como esperado, a morfologia de ambas é co-contínua. 
Figura 75 - MEV das blendas de PP/TPS-AC após extração do TPS 50/50 (a), 50/50 com anidrido maleico (b), 70/30 (c), 70/30 com anidrido maleico (d).

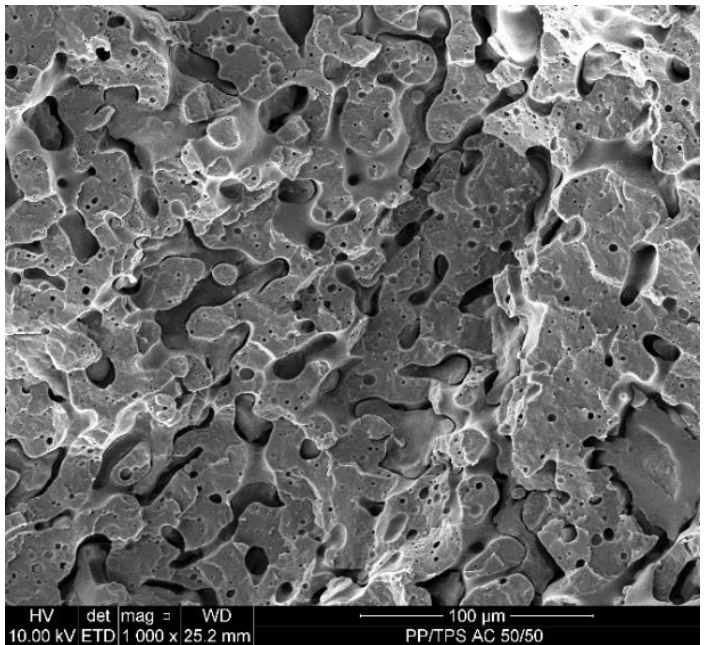

(a)

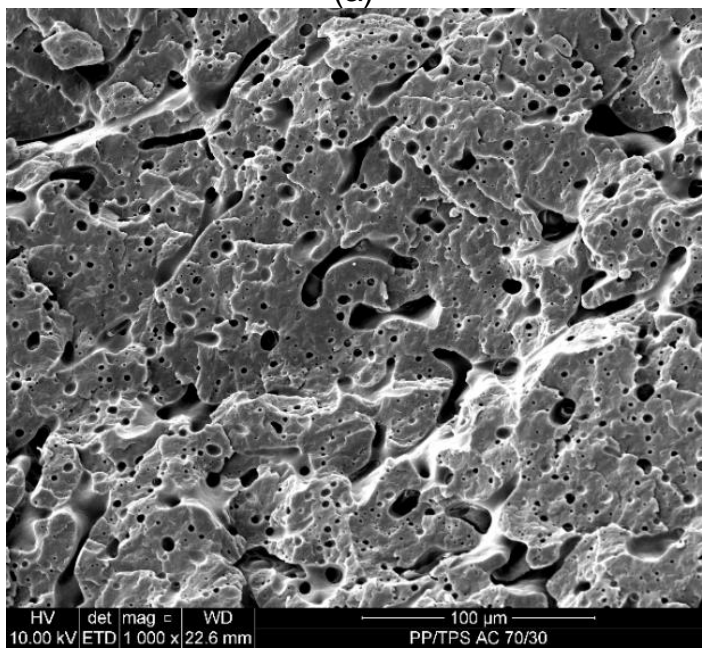

(c)

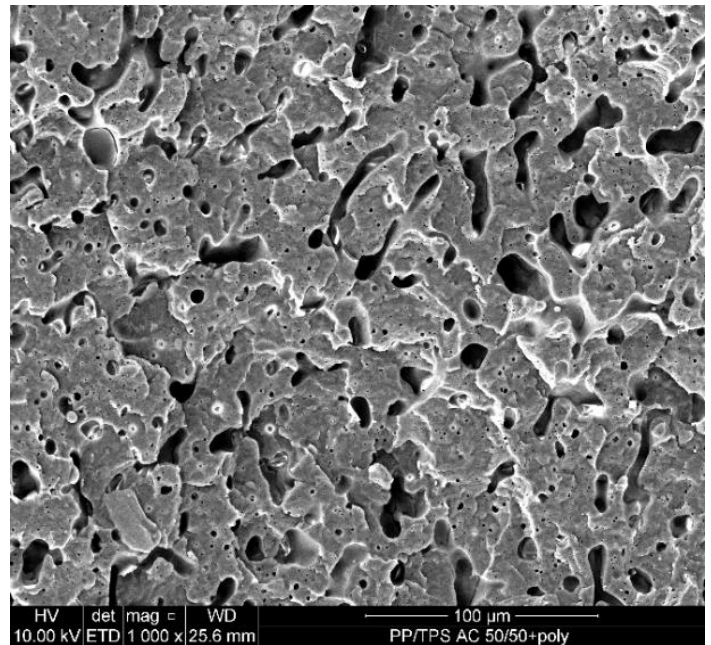

(b)

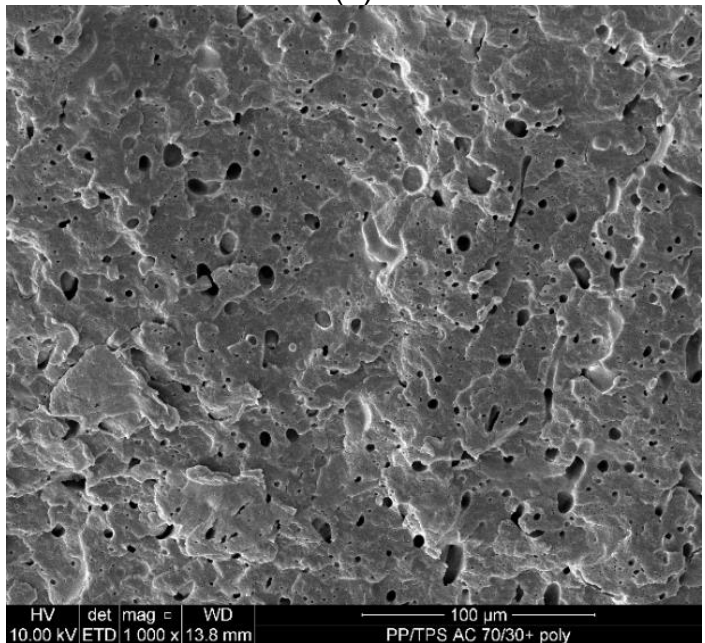

(d) 
Figura 76 - MEV das blendas de PP/TPS-AT após extração do TPS 50/50 (a), 50/50 com anidrido maleico (b), 70/30 (c), 70/30 com anidrido maleico (d).

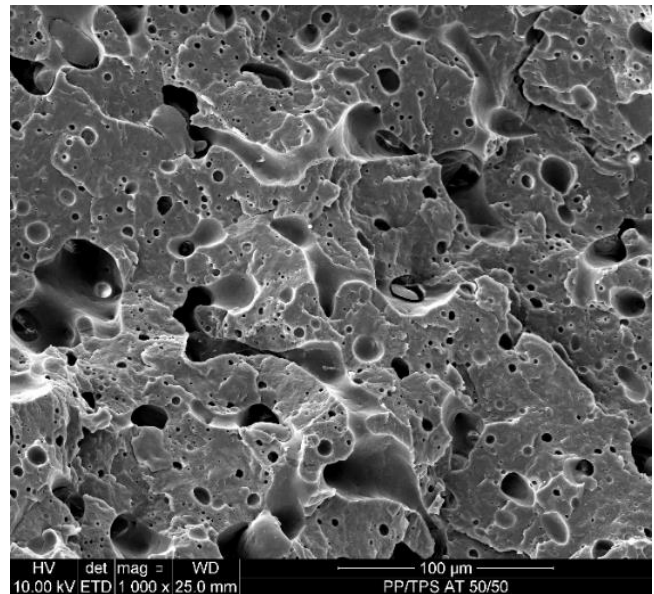

(a)

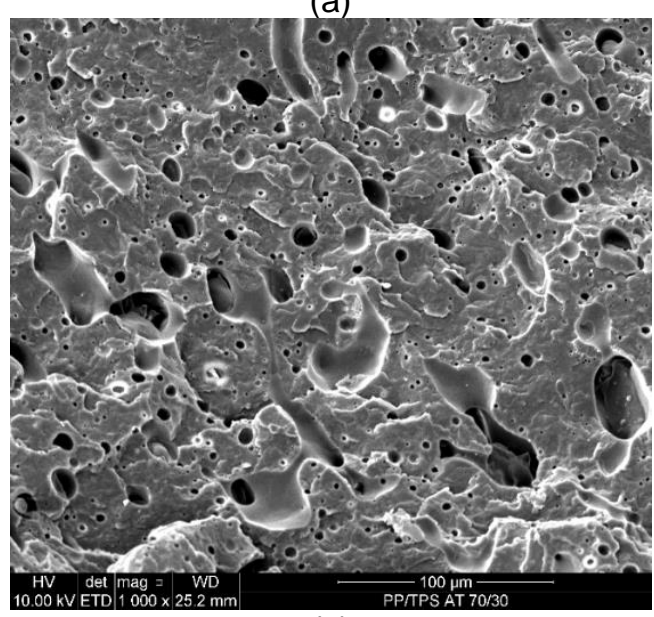

(c)

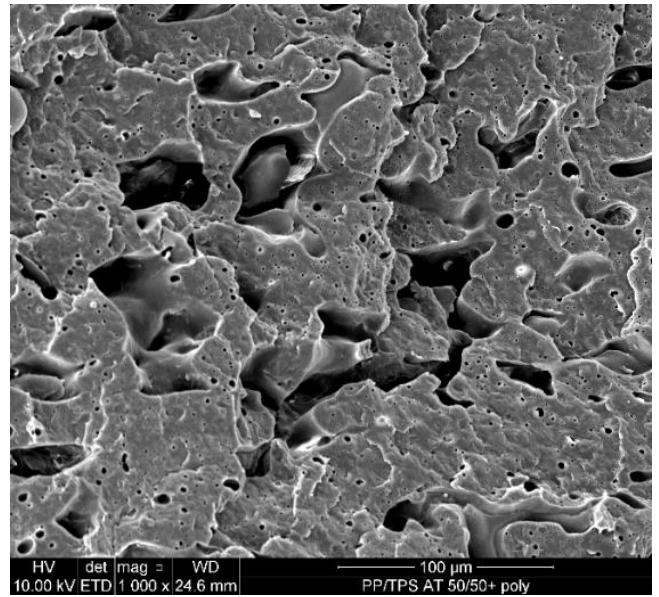

(b)

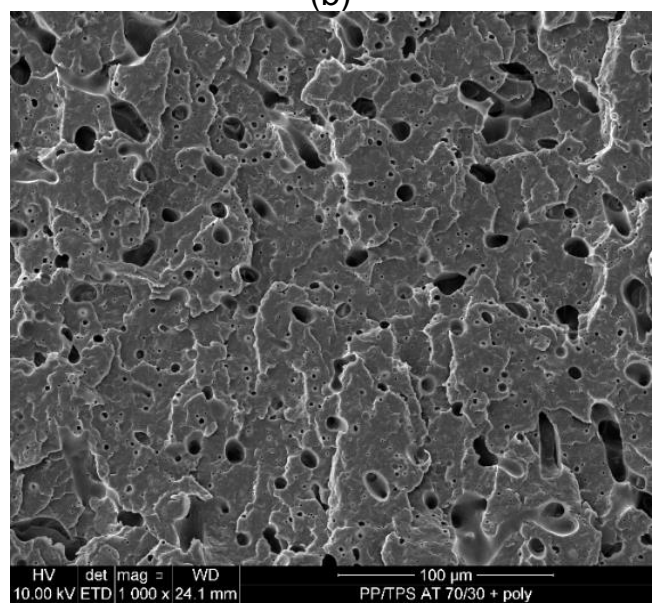

(d)

Figura 77 - MEV das blendas de PP/TPS-AM após extração do TPS 50/50 com anidrido maleico (a), 70/30 com anidrido maleico (b).

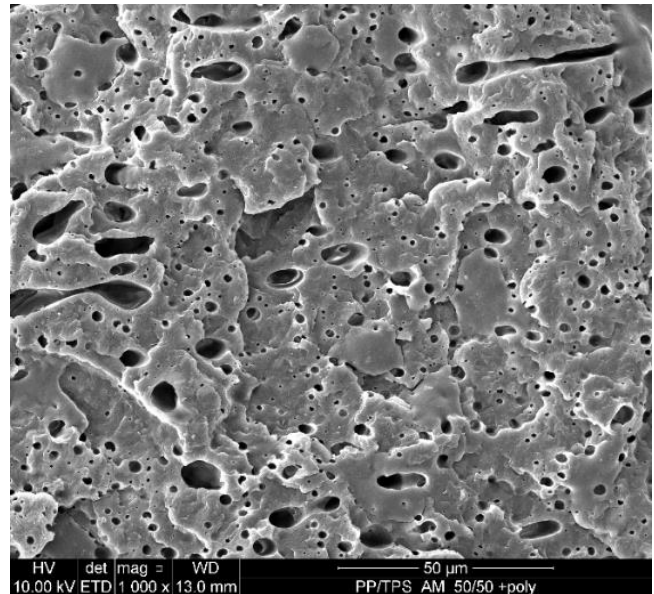

(a)

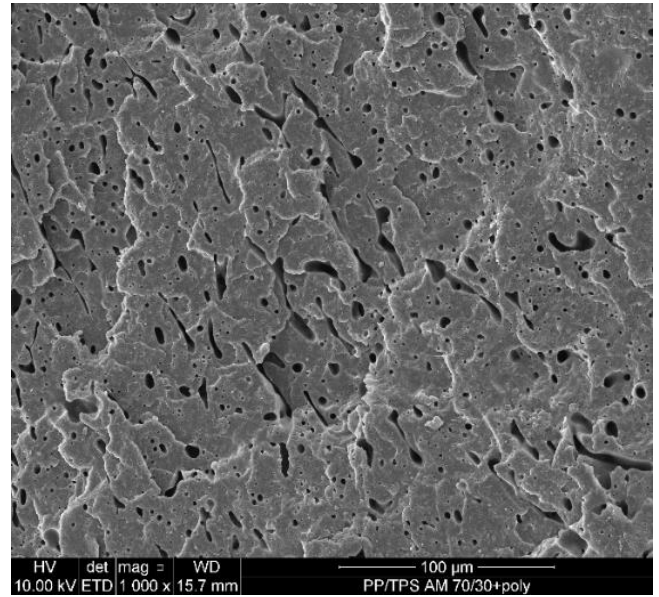

(b) 


\subsubsection{Propriedades Mecânicas: Ensaio de Tração}

A Figura 78 mostra as propriedades mecânicas dos TPS puro. Nota-se que eles possuem o mesmo comportamento dos TPS que foram misturados no mixer, discutido no Capítulo 3.

A Figura 79 mostra as propriedades mecânicas das blendas de PP/TPS 50/50 com e sem a adição de anidrido maleico. Observa-se que há uma queda nos valores de resistência à tração e módulo de elasticidade do PP reciclado, quando comparado ao PP não reciclado. Isso ocorre devido à cisão de cadeias do material.

Ao adicionar anidrido maleico tanto no PP quanto no PP reciclado observa-se a mesma tendência: redução nos valores de resistência à tração, mas os valores de módulo de elasticidade não são alterados.

Nas blendas 70/30:

- Os valores de resistência à tração das blendas com TPS e PP-g-MA, sem ácido e com ácido málico, são próximos aos obtidos para a fase matriz pura, o PP reciclado com PP-g-MA. As blendas com TPS e PP-g-MA e ácido tartárico possuem valores menores do que os obtidos para o PP reciclado + PP-g-MA, e a redução é ainda maior para as blendas com ácido cítrico. As blendas sem adição de PP-g-MA, com ácido possuem valores de resistência à tração menores do que o da fase matriz, PP reciclado.

- Ao comparar as amostras das blendas sem ácido e com ácido málico e tartárico, verifica-se que não há diferenças nos valores de propriedades mecânicas em função da adição de PP-g-MA, considerando o desvio padrão. Apenas a blenda com adição de ácido cítrico e PP-g-MA apresenta um pequeno aumento nos valores de resistência à tração, quando comparada à blenda sem PP-g-MA e ácido cítrico;

- Os valores de módulo de elasticidade das blendas com ácido são superiores ou equivalentes aos valores de módulo da fase matriz, PP reciclado ou PP reciclado + PP-g-MA. 
Nas blendas 60/40:

- Para as blendas 60/40 com adição de ácidos carboxílicos, não há diferença em propriedades mecânicas entre as blendas com e sem adição de PP-g-MA. Para a blenda sem adição de ácido há um pequeno aumento nos valores de resistência à tração em função da adição do PP-g-MA;

- Todas as blendas com adição de ácido carboxílico em PP reciclado apresentam redução nos valores de resistência à tração e valores de módulo de elasticidade equivalentes aos obtidos para o PP reciclado. Apenas a blenda sem adição de ácido apresenta valores de módulo superiores ao do PP reciclado.

- As blendas com adição de ácido carboxílico e PP-g-MA possuem valores de resistência à tração inferiores aos obtidos para o PP reciclado + PP-g-MA. Entretanto, sem adição de ácido, os valores de resistência são equivalentes aos do PP reciclado + PP-g-MA. Em relação ao módulo de elasticidade, blendas com ácido + PP-g-MA em PP reciclado possuem valores semelhantes aos obtidos para a fase matriz e blendas sem ácido possuem valores superiores.

Nas blendas 50/50:

- Para as blendas 50/50 com adição de ácidos carboxílicos, não há diferença nas propriedades mecânicas com a adição de PP-g-MA no PP reciclado. Para a blenda sem adição de ácido, observa-se aumentos nos valores de resistência à tração em função da adição de PP-g-MA.

- Para as blendas com adição de ácidos carboxílicos no PP reciclado, há redução nos valores de módulo e resistência à tração, em relação ao PP reciclado puro. Para a blenda sem ácido há significativo aumento nos valores de módulo, quando comparado aos valores do PP reciclado.

- Para as blendas com adição de ácido e PP-g-MA há, novamente, redução nos valores de resistência à tração, quando comparadas ao PP reciclado + PP-g-MA, mas os valores de módulo não foram alterados. Entretanto para a mistura sem adição de ácidos os valores de resistência são semelhantes aos obtidos para o PP reciclado + PP-g-MA e os valores de módulo são superiores. 
Então, como conclusão da etapa de caracterização mecânica, observa-se que a presença de ácido geralmente reduz as propriedades de blendas de PP e TPS e a adição de PP-g-MA é mais efetiva nas blendas sem adição de ácido.

Figura 78 - Propriedades Mecânicas dos TPS puros: Módulo de Elasticidade (a), Resistência a tração (b) e Alongamento na Ruptura (c).

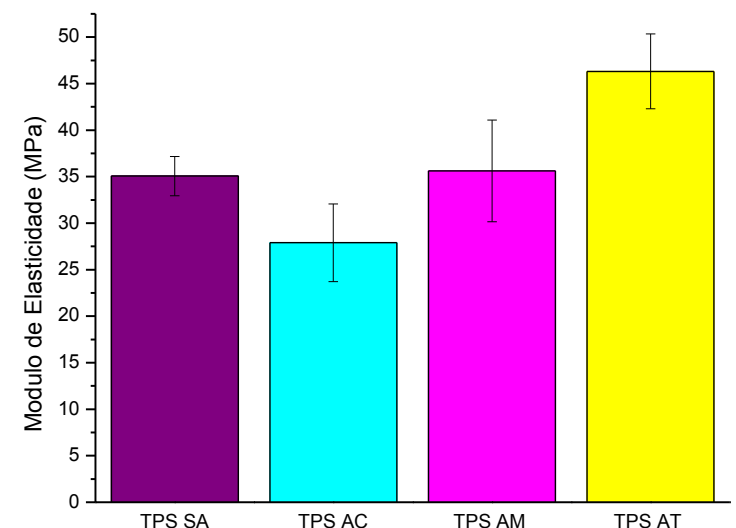

(a)

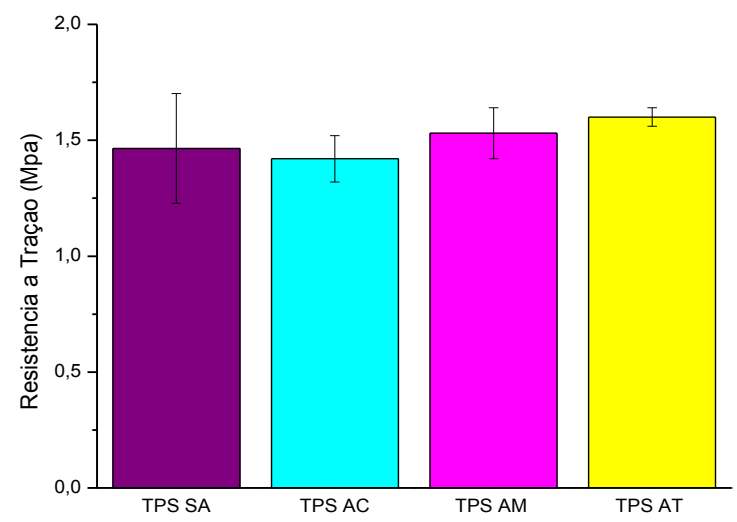

(b)

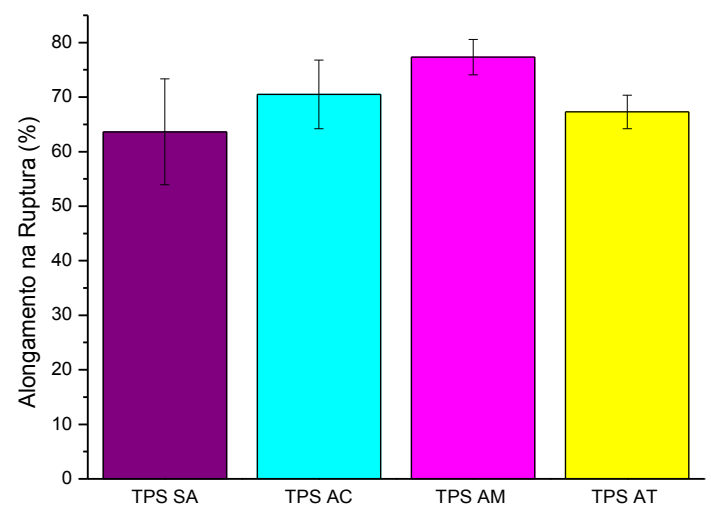

(c) 
Figura 79 - Propriedades Mecânicas das Blendas PP/TPS nas proporções 70/30 (a), 60/40 (b) e 50/50 (c): Resistência a tração e Módulo de Elasticidade.
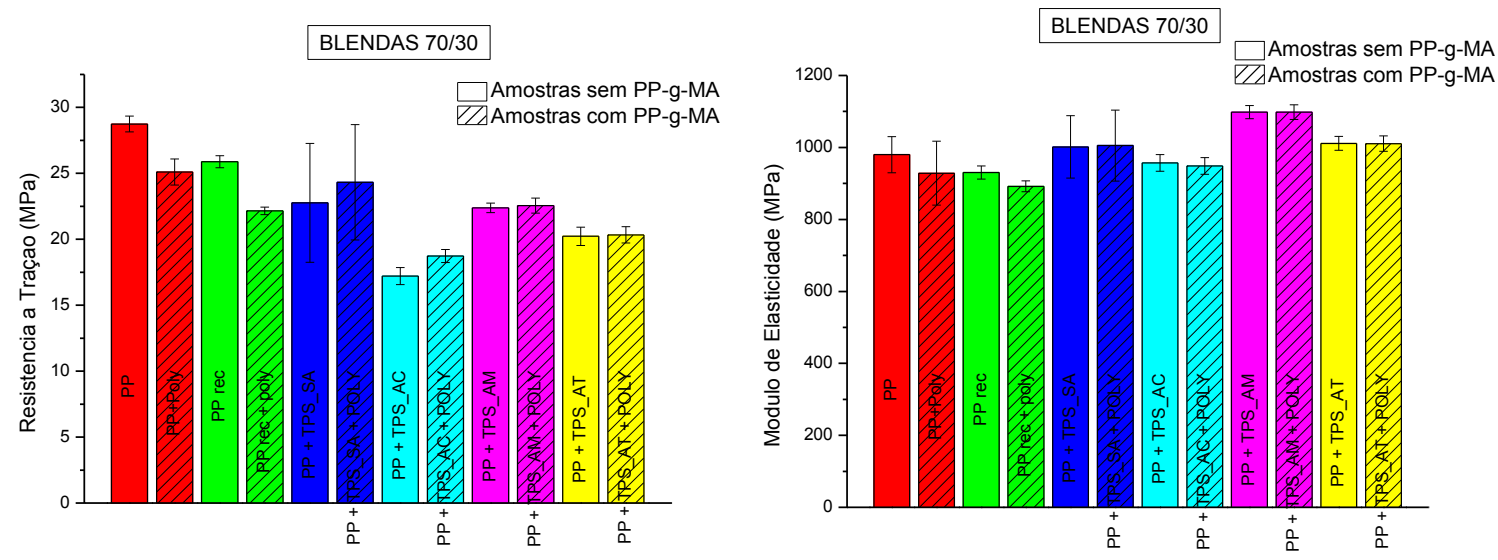

a) Blendas PP/TPS 70/30
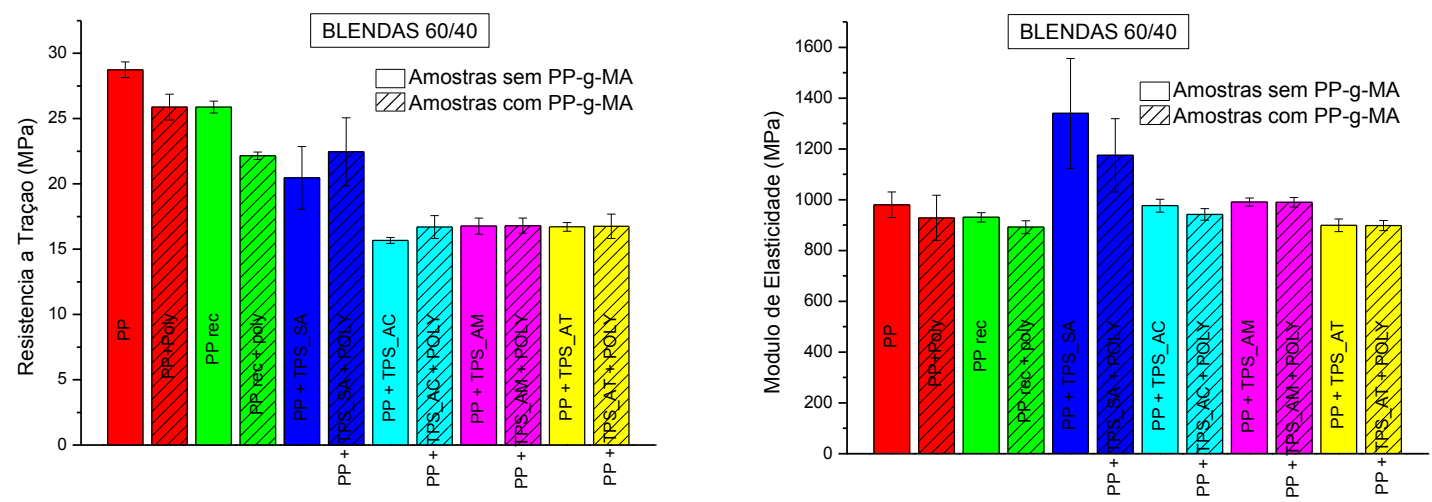

b) Blendas PP/TPS $60 / 40$
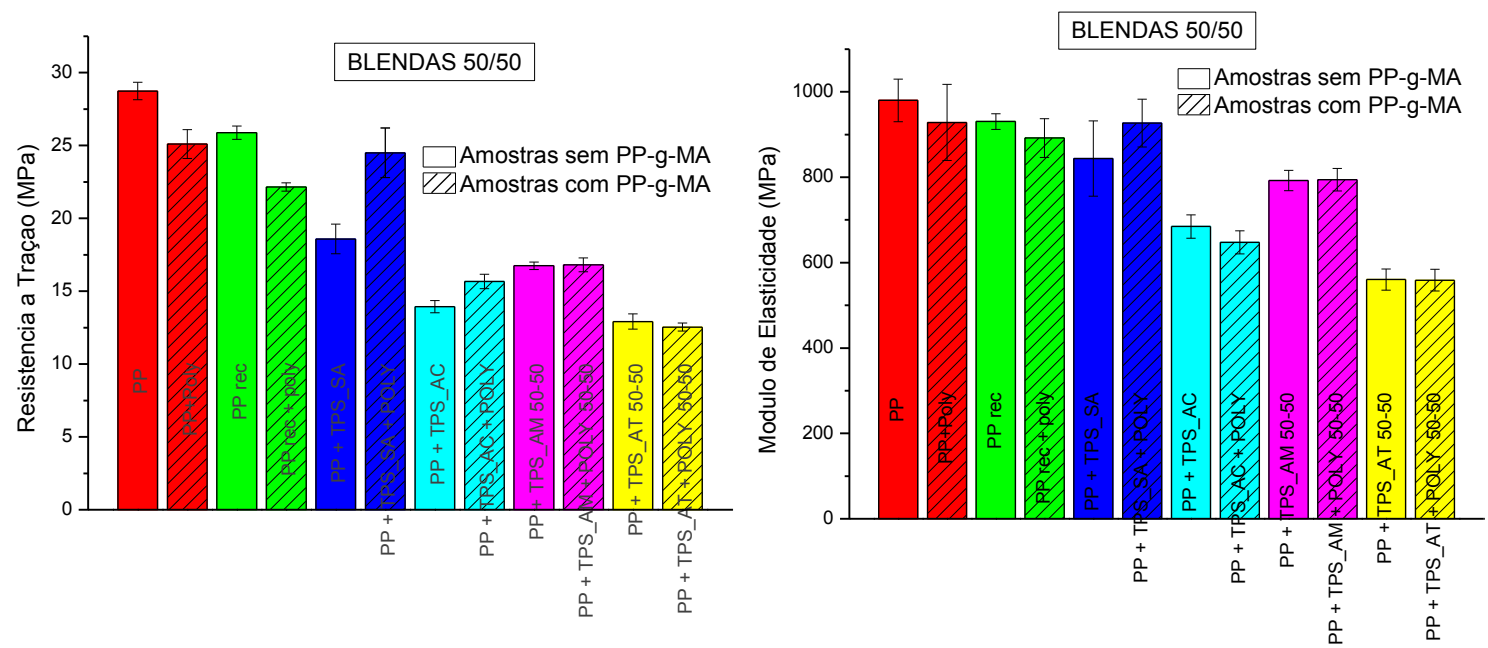

c) Blendas PP/TPS 50/50 
A Tabela 21 mostra os valores do Módulo de Elasticidade calculado e obtido experimentalmente. Nota-se que para todas as amostras o valor obtido é superior ao calculado pela regra das misturas. Mostrando que houve sinergismo das propriedades.

Tabela 21 - Comparação dos valores de módulo de elasticidade, calculados e experimentais, das blendas.

\begin{tabular}{|c|c|c|c|}
\hline & & $\begin{array}{l}\text { Valor Experimental } \\
(\mathrm{MPa})\end{array}$ & Valor Calculado (Mpa) \\
\hline \multirow{3}{*}{$\begin{array}{c}\text { Blenda PP/TPS- } \\
\text { SA }\end{array}$} & $50 / 50$ & 843 & 482 \\
\hline & $60 / 40$ & 1339 & 572 \\
\hline & $70 / 30$ & 1001 & 662 \\
\hline \multirow{3}{*}{$\begin{array}{c}\text { Blenda PP/TPS- } \\
\text { SA + anidrido } \\
\text { maleico }\end{array}$} & $50 / 50$ & 927 & 464 \\
\hline & $60 / 40$ & 1175 & 549 \\
\hline & $70 / 30$ & 1005 & 635 \\
\hline \multirow{3}{*}{$\begin{array}{c}\text { Blenda PP/TPS- } \\
\text { AC }\end{array}$} & $50 / 50$ & 685 & 479 \\
\hline & $60 / 40$ & 976 & 570 \\
\hline & $70 / 30$ & 957 & 660 \\
\hline \multirow{3}{*}{$\begin{array}{c}\text { Blenda PP/TPS- } \\
\text { AC + anidrido } \\
\text { maleico }\end{array}$} & $50 / 50$ & 648 & 460 \\
\hline & $60 / 40$ & 942 & 546 \\
\hline & $70 / 30$ & 948 & 633 \\
\hline \multirow{3}{*}{$\begin{array}{l}\text { Blenda PP/TPS- } \\
\text { AM }\end{array}$} & $50 / 50$ & 792 & 483 \\
\hline & $60 / 40$ & 991 & 573 \\
\hline & $70 / 30$ & 1098 & 662 \\
\hline \multirow{3}{*}{$\begin{array}{l}\text { Blenda PP/TPS- } \\
\text { AM + anidrido } \\
\text { maleico }\end{array}$} & $50 / 50$ & 794 & 464 \\
\hline & $60 / 40$ & 990 & 549 \\
\hline & $70 / 30$ & 1098 & 635 \\
\hline \multirow{3}{*}{$\begin{array}{l}\text { Blenda PP/TPS- } \\
\text { AT }\end{array}$} & $50 / 50$ & 560 & 488 \\
\hline & $60 / 40$ & 899 & 577 \\
\hline & $70 / 30$ & 1011 & 665 \\
\hline \multirow{3}{*}{$\begin{array}{c}\text { Blenda PP/TPS- } \\
\text { AT + anidrido } \\
\text { maleico }\end{array}$} & $50 / 50$ & 559 & 469 \\
\hline & $60 / 40$ & 898 & 554 \\
\hline & $70 / 30$ & 1010 & 638 \\
\hline
\end{tabular}

\subsubsection{ENVELHECIMENTO DA BLENDA}

A Figura 80 mostra as propriedades Mecânicas: Resistência à tração e Módulo de Elasticidade das Blendas do TPS novo e envelhecido. A Figura 81 mostra as propriedades mecânicas: Resistência à tração e Módulo de Elasticidade, das Blendas 
PP/TPS - SA e PP/TPS - AC envelhecidas. Pode-se observar que nas blendas 50/50 e 60/40, sem ácido e com ácido cítrico, o módulo diminui com o tempo. Já nas blendas 70/30 o módulo aumenta. A resistência à tração diminui com o tempo para todas as blendas.

Figura 80 - Propriedades Mecânicas: Módulo de Elasticidade (a), Resistência à tração (b) e Alongamento na Ruptura (c) dos TPS com e sem ácidos, novos e estocadas.

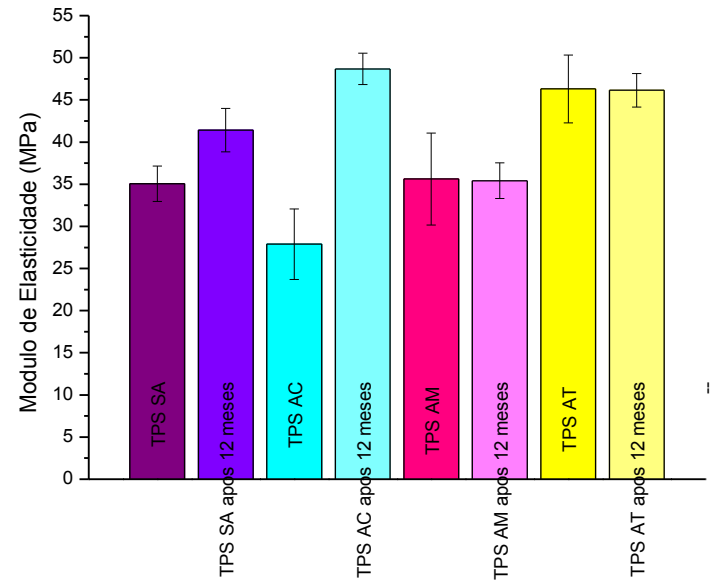

(a)

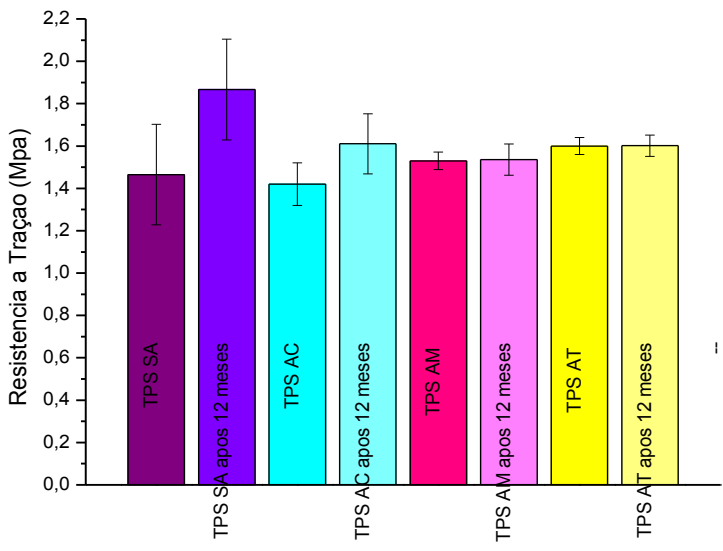

(b)

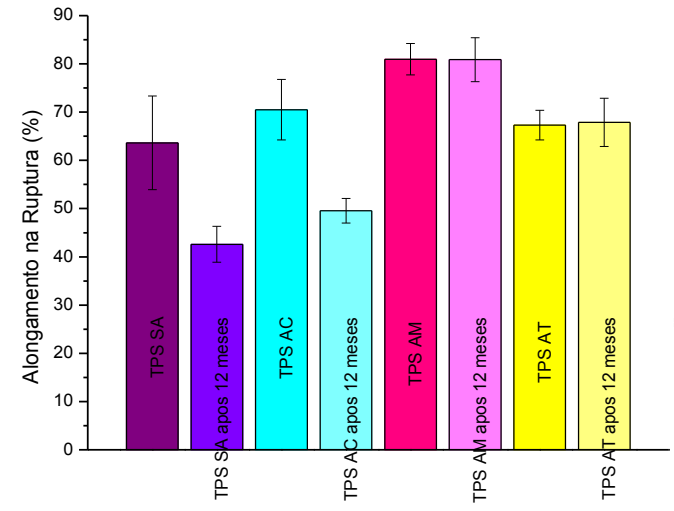

(c) 
Figura 81 - Propriedades Mecânicas: Resistência à tração e Módulo de Elasticidade das Blendas PP/TPS - SA e PP/TPS - AC envelhecidas.
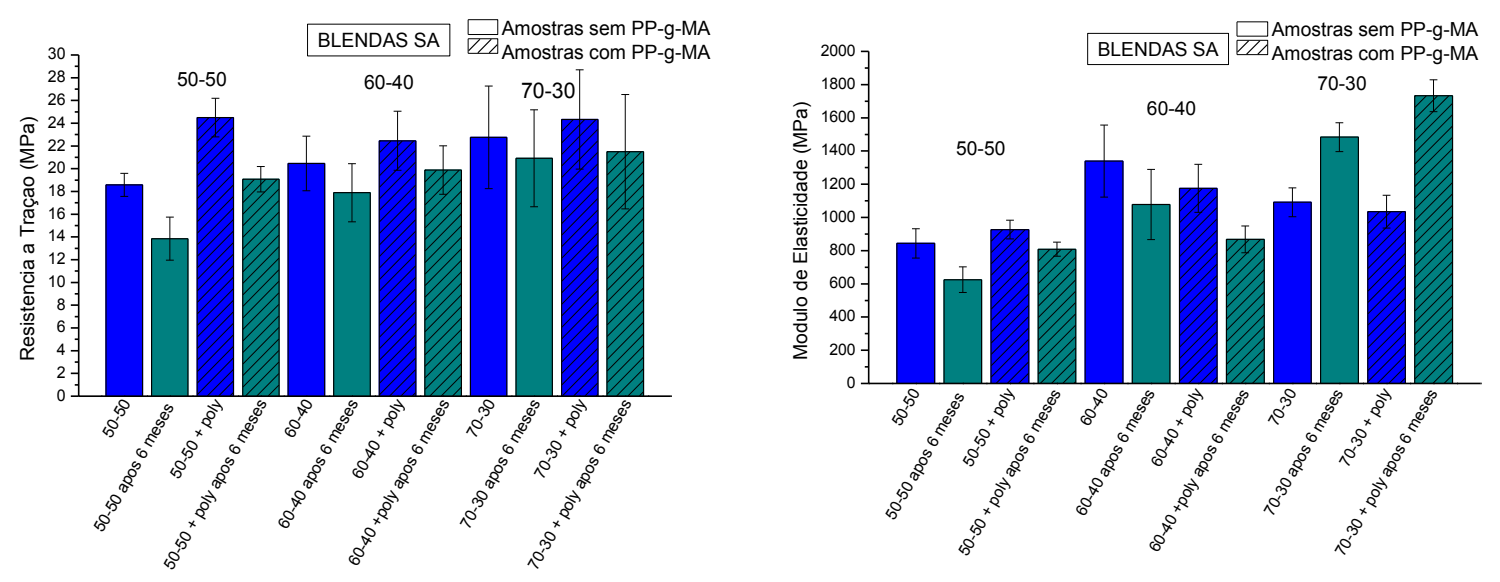

a) Blendas PP/TPS - SA
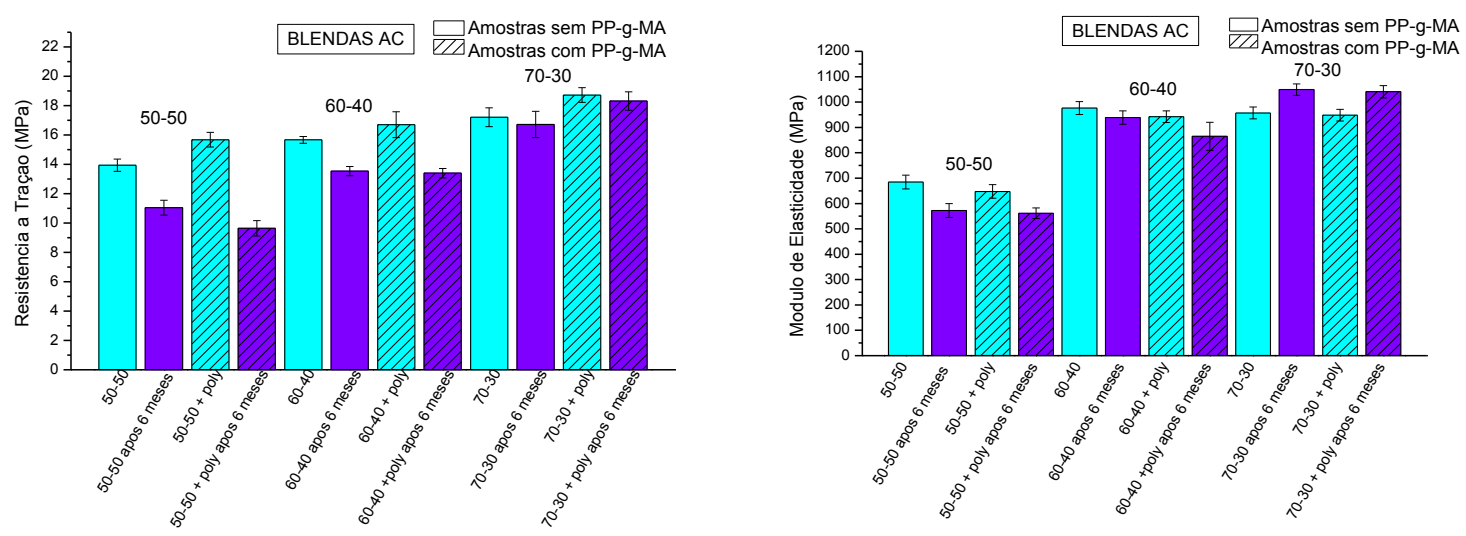

b) Blendas PP/TPS - AC

A Figura 82 mostra as propriedades mecânicas, Resistência à tração e Módulo de Elasticidade, das Blendas PP/TPS - AM e PP/TPS - AT envelhecidas. Pode-se observar que com o tempo não houve alteração das propriedades mecânicas. O que corrobora com os resultados do TPS puro. Indicando que apenas o TPS sofre alteração com o tempo. 
Figura 82 - Propriedades Mecânicas: Resistência à tração e Módulo de Elasticidade das Blendas PP/TPS - AM e PP/TPS - AT envelhecidas.
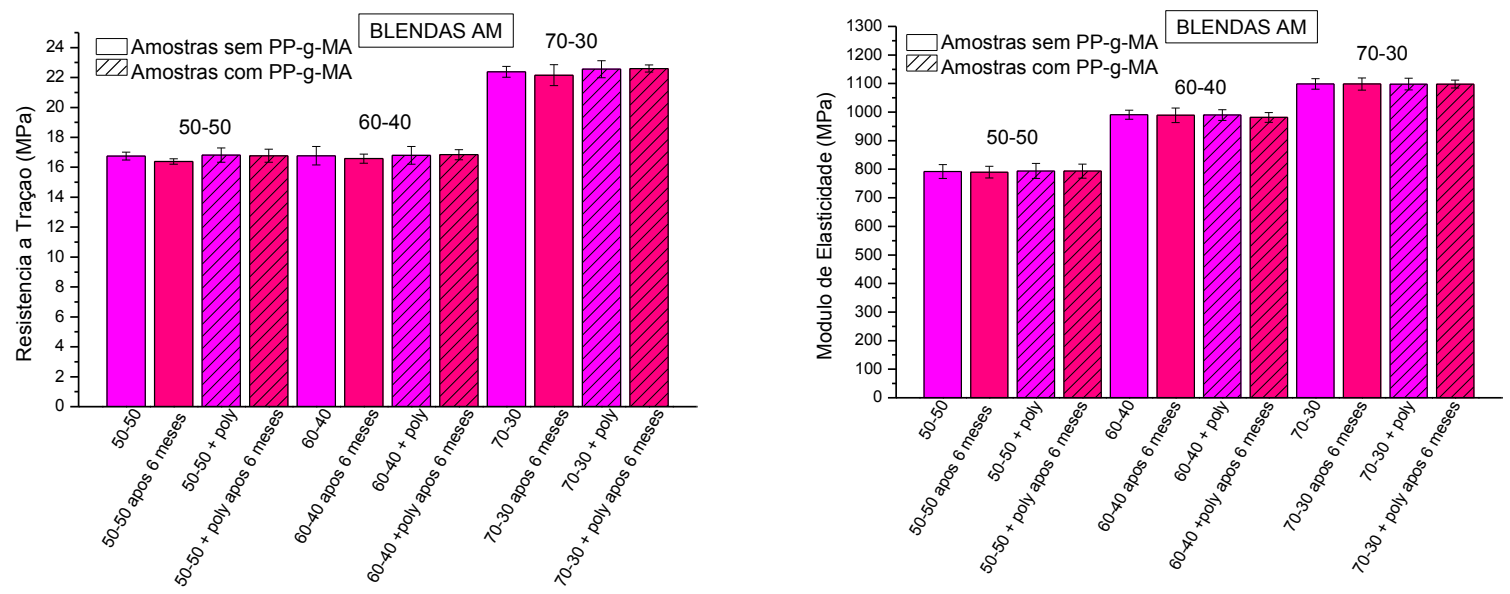

a) Blendas PP/TPS - AM
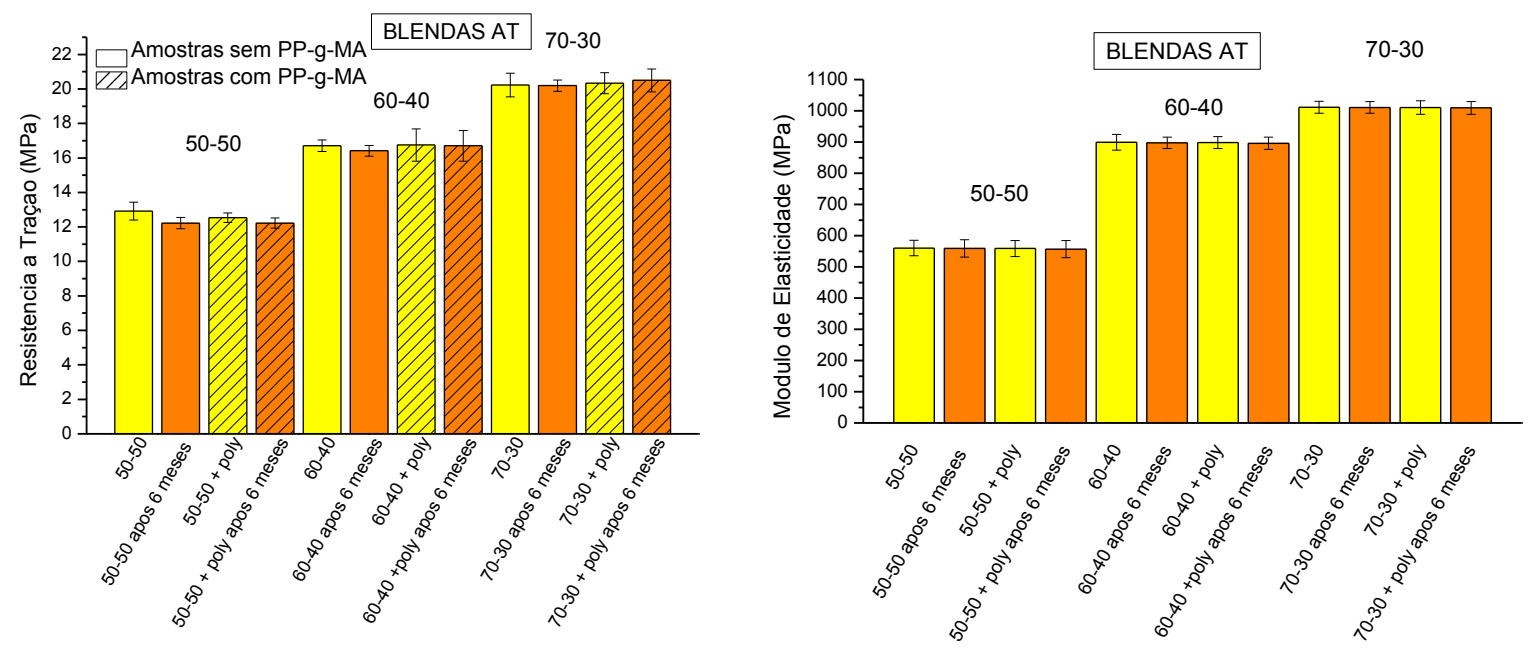

b) Blendas PP/TPS - AT

Ao analisar o DRX das blendas envelhecidas não são observadas alterações na cristalinidade, pois como a cristalinidade do PP é mais intensa que a cristalinidade do TPS, logo, observa-se apenas os picos referentes ao PP. A Figura 83 mostra as curvas de DRX da amostra PP/TPS-AC 50/50, que pelos ensaios mecânicos é uma das amostras mais críticas. 
Figura 83 - Curvas de DRX da amostra PP/TPS-AC 50/50 nova e estocada

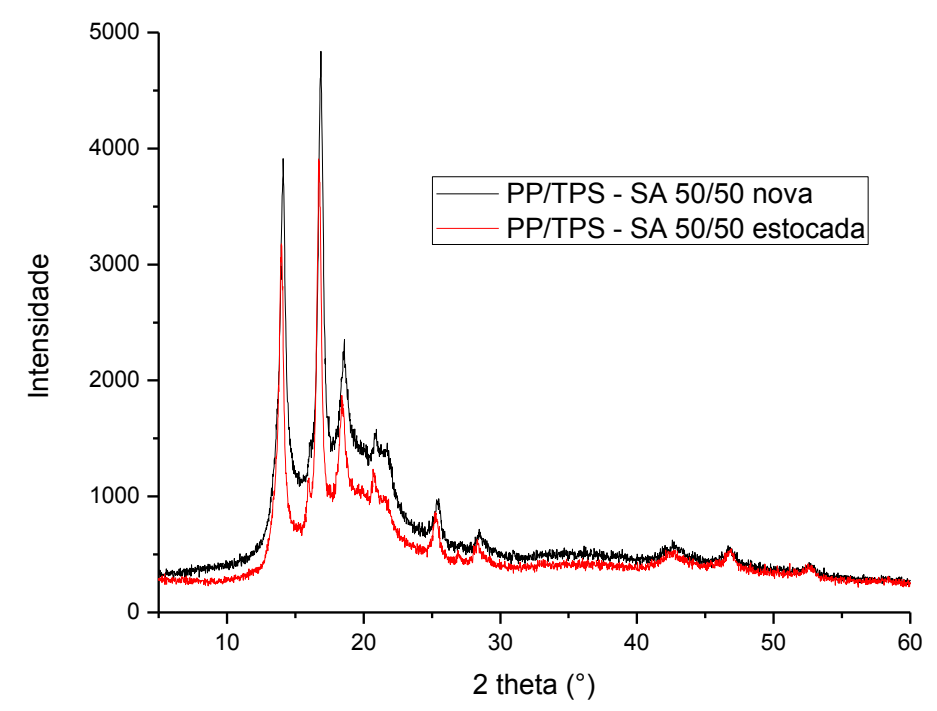

\subsection{CONCLUSÕES DO CAPÍTULO}

Neste capítulo foi realizado o estudo da compatibilização da blenda de PP reciclado e TPS nas proporções: 70/30, 60/40 e 50/50. Na parte experimental o TPS, primeiramente, foi preparado com $30 \%$ em massa de glicerol, $20 \%$ em massa de água e com $2 \%$ em massa dos ácidos carboxílicos: cítrico, málico e tartárico. Algumas amostras não continham ácidos. O TPS foi extrudado e depois misturado com o PP puro ou com o PP com PP-g-MA. A partir dos resultados obtidos, pode-se notar que:

- O PP reciclado não sofreu alteração na estrutura cristalina, quando comparado ao PP não reciclado. Entretanto, ao se adicionar PP-g-MA ao PP, ocorre uma pequena mudança na sua estrutura cristalina;

- Nas blendas, conforme o teor de TPS aumenta há uma queda nos valores de intensidade dos picos de difração do PP;

- Micrografias obtidas por MEV indicaram que todas as composições estudadas possuem morfologia predominantemente co-contínua, e alguns domínios de fase dispersa possuem a formato de gotas;

- Para as blendas sem ácido e com ácido cítrico, observou-se uma melhor compatibilização nas blendas com PP-g-MA; já nas blendas com ácido málico 
e tartárico não há diferença significativa na morfologia das blendas com e sem anidrido maleico;

- Os valores de módulo de elasticidade das blendas 70/30 com ácido são superiores ou equivalentes aos valores de módulo da fase matriz;

- As blendas 60/40 e 50/50 com adição de ácido carboxílico no PP reciclado apresentam redução nos valores de resistência à tração e de módulo de elasticidade equivalentes à obtida para o PP reciclado;

- A adição de PP-g-MA é mais efetiva nas blendas sem adição de ácido;

- Analisando as blendas estocadas notou-se que a fase de TPS envelhece, perde plastificante, e a fase de PP não se altera. 


\section{CAPÍTULO 6 - CONCLUSÕES, CONSIDERAÇÕES FINAIS E SUGESTÕES PARA TRABALHOS FUTUROS}

\subsection{INTRODUÇÃO}

Neste Capítulo serão apresentados um resumo e as principais conclusões de cada um dos estudos conduzidos neste trabalho. Também será feita uma conclusão final a respeito de todo o estudo e dos materiais abrangidos nesta pesquisa. As contribuições para o conhecimento geradas a partir deste trabalho serão expostas e, por fim, serão dadas sugestões para trabalhos futuros.

\subsection{RESUMO E CONCLUSÕES PRINCIPAIS DOS ESTUDOS}

Neste tópico será realizado um resumo dos estudos conduzidos e suas principais conclusões. Maiores detalhes sobre os resultados obtidos em cada capítulo encontram-se ao final de cada um deles.

\subsubsection{Estudo do TPS}

O estudo do TPS foi realizado através de um planejamento estatístico que otimizou a composição e os parâmetros a serem utilizados no processamento do TPS em um mixer. Verificou-se que a melhor composição foi de $30 \% \mathrm{em}$ massa de glicerol e $2 \%$ de ácido cítrico, e as condições de processamento de 8 min a 125ㄷ e 100rpm.

Após esse estudo foram preparados TPS com diferentes ácidos carboxílicos, utilizando os parâmetros acima. Como não se chegou a um consenso em relação ao teor de água, foram utilizadas as composições de 20 e 30\% em massa.

Os TPS com os ácidos málico e tartárico possuem melhores propriedades mecânicas e térmicas, quando comparados aos TPS com os outros ácidos. 


\subsubsection{Estudo sobre o Envelhecimento do TPS}

$O$ envelhecimento do TPS foi investigado armazenando o material em condições de estocagem. A amostra foi fechada e colocada em um local sem luz, a temperatura ambiente. $O$ efeito do envelhecimento foi analisado através da mudança na cristalinidade, na estrutura química, bem como nas suas propriedades térmicas e mecânicas.

O envelhecimento pode gerar mudanças no TPS, tais como: relaxamento das moléculas, que resulta em mudança na $T_{g}$ do material, alteração das propriedades mecânicas e mudança na cristalinidade devido, principalmente, à formação de uma estrutura intermolecular dupla hélice e da re-cristalização de amilopectina ou cristalização de amilose para para novos cristais do tipo V.

O TPS envelhece com o tempo, perdendo plastificante. Então, podem ser observadas mudanças na $T_{g}$, estrutura química, teor de cristalinidade e propriedades mecânicas do TPS. O TPS com os ácidos málico e tartárico não apresentaram alterações após um ano de estocagem. Isso não significa que não irá ocorrer o envelhecimento, o envelhecimento foi apenas retardado.

\subsubsection{Estudo da Blenda PP e TPS}

A compatibilização da blenda de PP reciclado e TPS foi analisada através da utilização de anidrido maleico, ácido cítrico, ácido málico e ácido tartárico. Analisando a caracterização mecânica observa-se que a presença de ácido geralmente reduz as propriedades de blendas de PP e TPS e a adição de PP-g-MA é mais efetiva nas blendas sem adição de ácido. Entretanto, após algum tempo estocado, as propriedades mecânicas do material se alteram devido à perda de plastificante da fase de TPS.

As micrografias indicam que todas as composições estudadas possuem morfologia predominantemente co-contínua, e alguns domínios de fase dispersa possuem formato de gotas. 


\subsection{CONCLUSÕES FINAIS}

O tema de pesquisa principal desta tese foi o TPS e suas misturas com o PP. A motivação deste estudo foi o problema gerado pelo descarte de plástico no meio ambiente.

Foi analisada a melhor composição do TPS utilizando amido de milho, 30\% em massa de glicerol, água e quatro ácidos carboxílicos. As composições com $2 \%$ em massa de ácido málico e ácido tartárico mostraram melhores propriedades térmicas e mecânicas, além de uma melhora na processabilidade e homogeneidade das amostras, quando comparadas com o TPS sem ácido e com os ácidos: cítrico e adípico.

Avaliando as amostras de TPS em relação ao tempo de estocagem, após 12 meses as amostras com ácido málico e ácido tartárico não sofreram envelhecimento. Estes ácidos são mais estáveis e são capazes de formar ligações mais fortes e mais estáveis do que os demais ácidos. Pode ser que com maior tempo de estocagem estas amostras possam sofrer alterações.

Em relação as misturas do TPS, optou-se por utilizar um polímero não biodegradável, o PP, que é muito utilizado na indústria devido suas propriedades mecânicas e ao seu baixo custo. Esta mistura foi pouco explorada em estudos.

Foi realizado um estudo da compatibilização do TPS com o PP, utilizando alguns ácidos carboxílicos e anidrido maleico como compatibilizantes. Para as blendas sem ácido e com ácido cítrico, observou-se uma melhor compatibilização nas blendas com anidrido maleico; já nas blendas com ácido málico e tartárico não há diferença significativa na morfologia das blendas com e sem anidrido maleico; todas as composições estudadas possuem morfologia predominantemente co-contínua, e alguns domínios de fase dispersa possuem a formato de gotas;

\subsection{CONTRIBUIÇÕES PARA O CONHECIMENTO}

As principais contribuições para o conhecimento a partir do trabalho desenvolvido foram: 
- Avaliação do percentual de plastificante, bem como das melhores condições de processamento do TPS;

- Análise do efeito de cada plastificante, bem como das condições de processamento do TPS;

- Estudo do efeito dos ácidos carboxílicos: adípico, cítrico, málico e tartárico nas propriedades do TPS;

- Discussão acerca do envelhecimento do TPS, bem como o efeito de cada ácido carboxílico no armazenamento;

- Análise da compatibilização com os ácidos carboxílicos da blenda PP reciclado e TPS;

\subsection{SUGESTÕES PARA TRABALHOS FUTUROS}

Visando o aprofundamento dos resultados apresentados nesta tese, serão apresentadas algumas sugestões para trabalhos futuros.

\subsubsection{Estudo do TPS}

- Analisar as propriedades de barreira do TPS, visando entender como a umidade afeta as propriedades do material;

- Verificar o peso molecular do TPS para analisar como os ácidos influenciam;

- Estudar as reações envolvidas na biodegradação do TPS;

- Analisar a influência dos ácidos na biodegradação do TPS.

\subsubsection{Estudo sobre o Envelhecimento do TPS}

- Realizar o envelhecimento com diferentes teores de umidade;

- Analisar o envelhecimento em períodos diferentes.

\subsubsection{Estudo da Blenda PP e TPS}

- Analisar como o TPS afetou a massa molar do PP; 
- Estudar a biodegradação das blendas;

- Analisar como cada compatibilizante influencia na biodegradação do material. 


\section{REFERÊNCIAS BIBLIOGRÁFICAS}

[1] História do Plástico. Disponível em:

<<http://www.nossofuturoroubado.com.br/arquivos/julho_09/historia_plastico.html>.

>. Acesso em: 3 nov. 2012.

[2] PageGen. Disponível em: <http://www.cm-

amadora.pt/PageGen.aspx?WMCM_Paginald=42786>. Acesso em: 5 nov. 2012.

[3] Perfil 2013 - Industria Brasileira de Transformação de Material Plástico. [S.I.]: ABIPLAST - Associação Brasileira da Indústria do Plástico, 2014.

[4] Política Nacional de Resíduos Sólidos. . [S.I: s.n.], 2010.

[5] Panorama dos Resíduos Sólidos no Brasil - 2013. [S.I.]: ABRELPE -

Associação Brasileira de Empresas de Limpeza Pública e Resíduos Especiais, 2013.

[6] FECHINE, G. J. M. A Era dos Polímeros Biodegradáveis. Revista Plástico Moderno, 2010.

[7] ABNT NBR 15448-1. ABNT NBR 15448-1 - Embalagens Plásticas degradáveis e/ou de fontes renováveis. Parte I:Terminologia. [S.I: s.n.], 2008.

[8] ROSA, D. S. et al. The Effect of UV-B Irradiation on the Biodegradability of Poly$B$-Hydroxybutyrate ( PHB ) and Poly-E-Caprolactone (PCL). Journal of Polymers and the Environment, v. 9, n. 3, p. 109-113, 2002.

[9] BRITO, G. F. et al. Biopolímeros, Polímeros Biodegradáveis e Polímeros Verdes. Revista Eletrônica de Materiais e Processos, v. 6, n. 2, p. 127-139, 2011.

[10] MC CARTHY, S. P. "Plastics and the environment" Cap.9. Edited by ed. Estados Unidos: [s.n.], 2003.

[11] http://bioplasticnews.blogspot.com/2009/08/desenvolvimento-deplastico.html.

[12] Conferência da Nações Unidas sobre Desenvolvimento Sustentável Rio+20. Disponível em:

<http://www.rio20.gov.br/sobre_a_rio_mais_20/desenvolvimento-sustentavel.html>. Acesso em: 24 jan. 2015.

[13] FECHINE, G. J. . Polímeros Biodegradáveis- Tipos mecanismos, normas e mercado mundial. São Paulo - SP: Editora Mackenzie, 2014.

[14] STEVENS, E. S. Green Plastics: An introduction to the new science of biodegradable plastics. Princeton: Princeton University Press, 2002. 
[15] BEMILLER, J. . W. R. et al. Starch: Chemistry and Technology. $3^{\circ}$. ed. [S.I.]: Elsevier, 2009.

[16] GUINESI, L. S. et al. Kinetics of thermal degradation applied to starches from different botanical origins by non-isothermal procedures. Thermochimica Acta, v. 447, n. 2, p. 190-196, doi:10.1016/j.tca.2006.06.002, 2006.

[17] CORRADINI, E. . et al. Amido Termoplástico. Embrapa publicações. São Carlos: Embrapa Instrumentação Agropecuária, 2007. .

[18] DENARDIN, C. C. INFLUÊNCIA DO TEOR DE AMILOSE E BENEFICIAMENTO DO ARROZ NA RESPOSTA BIOLÓGICA DE RATOS. Universidade Federal de Santa Maria (UFSM, RS) - [S.I.]. 2008.

[19] CHANDRA, R. e RUSTGI, R. Biodegradable Polymers. Progress in Materials Science, v. 23, n. 7, p. 1273-1335, doi:10.1016/S0079-6700(97)00039-7, 1998.

[20] (NIST), N. I. of S. and T. No Title.

[21] AHMED, J. et al. Starch-Based Polymeric Materials and Nanocomposites Chemistry, Processing, and Applications. 1 $^{\text {a }}$ ed. Boca Raton, FL: CRC Press, 2012.

[22] LIU, H. et al. Thermal processing of starch-based polymers. Progress in Polymer Science, v. 34, n. 12, p. 1348-1368, doi:10.1016/j.progpolymsci.2009.07.001, 2009.

[23] RÓZ, A. L. Da e RÓZ, A. L. DA. Preparação e Caracterização de Amidos Termoplásticos. Universidade de São Paulo - Escola de Engenharia de São Carlos da Universidade de São Paulo, São Carlos. 2004.

[24] ISO 472:2013 - International Organization for Standardization - Plastics Vocabulary. . [S.I: s.n.], 2013.

[25] ASTM D20.96 Standard Test Methods - Environmentallly Degradable Plastics and Biobased Products - Committee D20 on Plastics. . West Conshohocken, PA. Estados Unidos.: [s.n.], [S.d.].

[26] SADI, R. K. Estudo da Combatibilização e da Degradação de Blendas Polipropileno/poli(3-hidroxibutirato) (PP/PHB). Escola Politécnica da Universidade de São Paul - [S.I.]. 2010.

[27] RAMIS, X. et al. Thermal degradation of polypropylene/starch-based materials with enhanced biodegradability. Polymer Degradation and Stability, v. 86, n. 3, p. 483-491, doi:10.1016/j.polymdegradstab.2004.05.021, 2004. 
[28] KACZMAREK, $\mathrm{H}$. et al. Effect of short wavelength UV-irradiation on ageing of polypropylene/cellulose compositions. Polymer Degradation and Stability, v. 88, n. 2, p. 189-198, doi:10.1016/j.polymdegradstab.2004.04.017, 2005.

[29] MORANCHO, J. M. M. et al. Calorimetric and thermogravimetric studies of UVirradiated polypropylene/starch-based materials aged in soil. Polymer Degradation and Stability, v. 91, n. 1, p. 44-51, doi:10.1016/j.polymdegradstab.2005.04.029, 2006.

[30] ABD EL-REHIM, H. a. et al. Synergistic effect of combining UV-sunlight-soil burial treatment on the biodegradation rate of LDPE/starch blends. Journal of Photochemistry and Photobiology A: Chemistry, v. 163, p. 547-556, doi:10.1016/j.jphotochem.2004.02.003, 2004.

[31] ERLANDSSON, B.; KARLSSON, S. e ALBERTSSON, A.-C. The mode of action of corn starch and a pro-oxidant system in LDPE: influence of thermo-oxidation and UV-irradiation on the molecular weight changes. Polymer Degradation and Stability, v. 55, p. 237-245, doi:10.1016/S0141-3910(96)00139-5, 1997.

[32] VILPOUX, O. e AVEROUS, L. Starch-based plastics. In: CEREDA, M. P. (Ed.). . Technology, use and potentialities of Latin American starch tubes. São Paulo: NGO Raizes e Cargill Foundation, 2002. p. 521-553.

[33] BOUSMINA, M.; AIT-KADI, A. e FAISANT, J. B. Determination of shear rate and viscosity from batch. Journal of Rheology, v. 43, p. 415-433, 1999.

[34] YU, L. e CHRISTIE, G. Microstructure and mechanical properties of orientated thermoplastic starches. Journal of Materials Science, v. 40, n. 1, p. 111-116, doi:10.1007/s10853-005-5694-1, 2005.

[35] LELIEVRE, J. Starch gelatinization. Journal of Applied Polymer Science, v. 18, n. 1, p. 293-296, doi:10.1002/app.1974.070180124, 1974.

[36] MA, X. F.; YU, J. G. e WAN, J. J. Urea and ethanolamine as a mixed plasticizer for thermoplastic starch. Carbohydrate Polymers, v. 64, n. 2, p. 267-273, doi:10.1016/j.carbpol.2005.11.042, 2006.

[37] HUANG, M.; YU, J. e MA, X. Ethanolamine as a novel plasticiser for thermoplastic starch. Polymer Degradation and Stability, v. 90, n. 3, p. 501-507, doi:10.1016/j.polymdegradstab.2005.04.005, 2005.

[38] TEIXEIRA, E. M. et al. The effect of glycerol/sugar/water and sugar/water mixtures on the plasticization of thermoplastic cassava starch. Carbohydrate Polymers, v. 69, n. 4, p. 619-624, doi:10.1016/j.carbpol.2007.01.022, 2007. 
[39] CÓRDOBA, A. et al. The plasticizing effect of alginate on the thermoplastic starch/glycerin blends. Carbohydrate Polymers, v. 73, n. 3, p. 409-416, doi:10.1016/j.carbpol.2007.12.007, 2008.

[40] MA, X. e YU, J. The plastcizers containing amide groups for thermoplastic starch. Carbohydrate Polymers, v. 57, n. 2, p. 197-203, doi:10.1016/j.carbpol.2004.04.012, 2004.

[41] LOURDIN, D. et al. Influence of equilibrium relative humidity and plasticizer concentration on the water content and glass transition of starch materials. Polymer, v. 38, n. 21, p. 5401-5406, doi:10.1016/S0032-3861(97)00082-7, 1997.

[42] SCHLEMMER, D. et al. Morfologia de Filmes de Amido Termoplástico e Montmorilonita ( TPS / MMT ) usando Óleos Vegetais do Cerrado como Plastificantes. In: $10^{\circ}$ CONGRESSO BRASILEIRO DE POLÍMEROS. Anais... Foz do Iguaçu: [s.n.], 2009.

[43] BENDAOUD, A. e CHALAMET, Y. Effects of relative humidity and ionic liquids on the water content and glass transition of plasticized starch. Carbohydrate Polymers, v. 97, n. 2, p. 665-75, doi:10.1016/j.carbpol.2013.05.060, 2013.

[44] ONTENIENTE, J.; ABBÈS, B. e SAFA, L. H. Fully Biodegradable Lubricated Thermoplastic Wheat Starch: Mechanical and Rheological Properties of an Injection Grade. Starch - Stärke, v. 52, n. 4, p. 112-117, doi:10.1002/1521379X(200006)52:4<112::AID-STAR112>3.0.CO;2-O, 2000.

[45] WALIA, P. S. et al. Effect of moisture level on the morphology and melt flow behavior of thermoplastic starch/poly(hydroxy ester ether) blends. Polymer, v. 41, n. 22, p. 8083-8093, doi:10.1016/S0032-3861(00)00149-X, 2000.

[46] NATIONAL INSTITUTE OF STANDARD AND TECHNOLOGY (NIST). Glycerin.

[47] WILLETT, J. L.; JASBERG, B. K. e SWANSON, C. L. Rheology of thermoplastic starch: Effects of temperature, moisture content, and additives on melt viscosity.

Polymer Engineering and Science, v. 35, n. 2, p. 202-210, doi:10.1002/pen.760350214, 1995.

[48] MAURANO, C. H. F.; GALLAND, G. B. e MAULER, R. S. Influência da estrutura de diferentes copolímeros de etileno e a-olefinas na funcionalização com anidrido maleico. Polímeros, v. 8, n. 3, p. 79-88, doi:10.1590/S0104-14281998000300011, 1998.

[49] STEPTO, R. F. T. Thermoplastic Starch. Macromolecular Symposia, v. 279, n. 1, p. 163-168, doi:10.1002/masy.200950525, 2009.

[50] Aplicações do ácido cítrico na indústria de alimentos. Food Ingredients Brasil, v. 30, p. 96-103, 2014. 
[51] Ácido Cítrico. Aditivos e Ingredientes, p. 30-35, 2014.

[52] NATIONAL INSTITUTE OF STANDARD AND TECHNOLOGY (NIST). Citric acid.

[53] OLIVATO, J. B. et al. Citric acid and maleic anhydride as compatibilizers in starch/poly(butylene adipate-co-terephthalate) blends by one-step reactive extrusion. Carbohydrate Polymers, v. 87, n. 4, p. 2614-2618, doi:10.1016/j.carbpol.2011.11.035, 2012.

[54] GARCIA, P. S. et al. Citric acid as multifunctional agent in blowing films of starch/PBAT. Química Nova, v. 34, n. 9, p. 1507-1510, doi:10.1590/S010040422011000900005, 2011.

[55] REDDY, N. e YANG, Y. Citric acid cross-linking of starch films. Food Chemistry, v. 118, n. 3, p. 702-711, doi:10.1016/j.foodchem.2009.05.050, 2010.

[56] WILPISZEWSKA, K. e CZECH, Z. Citric acid modified potato starch films containing microcrystalline cellulose reinforcement - properties and application. Starch - Stärke, v. 66, n. 7-8, p. 660-667, doi:10.1002/star.201300093, 2014.

[57] WANG, N. et al. Effect of citric acid and processing on the performance of thermoplastic starch/montmorillonite nanocomposites. Carbohydrate Polymers, v. 76, n. 1, p. 68-73, doi:10.1016/j.carbpol.2008.09.021, 2009.

[58] OLSSON, E. et al. Influence of citric acid and curing on moisture sorption, diffusion and permeability of starch films. Carbohydrate polymers, v. 94, n. 2, p. 765-72, doi:10.1016/j.carbpol.2013.02.006, 2013.

[59] XIAOFEI, M. et al. Properties of biodegradable citric acid-modified granular starch/thermoplastic pea starch composites. Carbohydrate Polymers, v. 75, n. 1, p. 1-8, doi:10.1016/j.carbpol.2008.05.020, 2009.

[60] MAJZOOBI, M. et al. Effects of malic acid and citric acid on the functional properties of native and cross-linked wheat starches. Starch - Stärke, v. 66, n. 5-6, p. 491-495, doi:10.1002/star.201300188, 2014.

[61] SHI, R. et al. Characterization of citric acid/glycerol co-plasticized thermoplastic starch prepared by melt blending. Carbohydrate Polymers, v. 69, n. 4, p. 748-755, doi:10.1016/j.carbpol.2007.02.010, 2007.

[62] HOLSER, R. A. Thermal analysis of glycerol citrate/starch blends. Journal of Applied Polymer Science, v. 110, n. 3, p. 1498-1501, doi:10.1002/app.27651, 2008.

[63] SILVA, I. F. E. et al. How reactive extrusion with adipic acid improves the mechanical and barrier properties of starch/poly (butylene adipate-co-terephthalate) 
films. International Journal of Food Science \& Technology, v. 48, n. 8, p. 1762 1769, doi:10.1111/ijfs.12148, 2013.

[64] KIM, W. e SHIN, M. Effects of organic acids and starch water ratios on the properties of retrograded maize starches. Food Science and Biotechnology, v. 20, n. 4, p. 1013-1019, doi:10.1007/s10068-011-0139-x, 2011.

[65] KASEEM, M.; HAMAD, K. e DERI, F. Thermoplastic starch blends: A review of recent works. Polymer Science Series A, v. 54, n. 2, p. 165-176, doi:10.1134/S0965545X1202006X, 2012.

[66] RÓZ, A. L. DA et al. Thermoplastic starch modified during melt processing with organic acids: The effect of molar mass on thermal and mechanical properties.

Industrial Crops and Products, v. 33, n. 1, p. 152-157, doi:10.1016/j.indcrop.2010.09.015, 2011.

[67] LUCAS, N. et al. Polymer biodegradation: mechanisms and estimation techniques. Chemosphere, v. 73, n. 4, p. 429-42, doi:10.1016/j.chemosphere.2008.06.064, 2008.

[68] ZURAIDA, A.; ANUAR, H. e YUSOF, Y. The Study of Biodegradable Thermoplastics Sago Starch. Key Engineering Materials, v. 471-472, n. 2011, p. 397-402, doi:10.4028/www.scientific.net/KEM.471-472.397, 2011.

[69] GARCIA, P. S. Ácido cítrico como compatibilizante entre amido e poliéster em filmes tubulares produzidos por extrusão. Universidade Estadual de Londrina - [S.I.]. 2010.

[70] TAGUET, A.; HUNEAULT, M. A. e FAVIS, B. D. Interface/morphology relationships in polymer blends with thermoplastic starch. Polymer, v. 50, n. 24, p. 5733-5743, doi:10.1016/j.polymer.2009.09.055, 2009.

[71] MOAD, G. Chemical modification of starch by reactive extrusion. Progress in Polymer Science, v. 36, n. 2, p. 218-237, doi:10.1016/j.progpolymsci.2010.11.002, 2011.

[72] COSTA, D. L. M. G. Da. Produção por extrusão de filmes de alto teor de amido termoplástico de mandioca com poli(butileno adipato co-tereftalato) (pbat). Universidade Estadual de Londrina - [S.I.]. 2008.

[73] CHEL-GUERRERO, L. e BETANCUR, A. D. Cross-Linkage of Canavalia ensiformis Starch with Adipic Acid: Chemical and Functional Properties. Journal of Agricultural and Food Chemistry, v. 46, n. 6, p. 2087-2091, doi:10.1021/jf970828d, 1998. 
[74] JIUGAO, Y.; NING, W. e XIAOFEI, M. The Effects of Citric Acid on the Properties of Thermoplastic Starch Plasticized by Glycerol. Starch - Stärke, v. 57, n. 10, p. 494-504, doi:10.1002/star.200500423, 2005.

[75] WANG, N. et al. Influence of Citric Acid on the Properties of Glycerol-plasticized dry Starch (DTPS) and DTPS/Poly(lactic acid) Blends. Starch - Stärke, v. 59, n. 9, p. 409-417, doi:10.1002/star.200700617, 2007.

[76] MIRANDA, V. R. e CARVALHO, A. J. F. Blendas compatíveis de amido termoplástico e polietileno de baixa densidade compatibilizadas com ácido cítrico. Polímeros, v. 21, n. 5, p. 353-360, doi:10.1590/S0104-14282011005000067, 2011.

[77] RAQUEZ, J.-M. et al. Maleated thermoplastic starch by reactive extrusion. Carbohydrate Polymers, v. 74, n. 2, p. 159-169, doi:10.1016/j.carbpol.2008.01.027, 2008.

[78] NING, W. et al. The influence of citric acid on the properties of thermoplastic starch/linear low-density polyethylene blends. Carbohydrate Polymers, v. 67, n. 3, p. 446-453, doi:10.1016/j.carbpol.2006.06.014, 2007.

[79] GAVA, A. J.; SILVA, C. A. B. DA e FRIA, J. R. G. Tecnologia de Alimentos: princípios e aplicações. São Paulo - SP: Nobel, 2009.

[80] SOCIEDADE BRASILEIRA DE QUÍMICA. Química Nova Interativa. Disponível em:

<http://qnint.sbq.org.br/qni/popup_visualizarMolecula.php?id=jxLL1f8pp0dhBRzYuD4 GzLb-

GiWPp7gty5tYYhQkd0JbDpjR6A89yUkEY1190OLj9sWtnuagrR3UpiKGwpqiBQ==>. Acesso em: 27 jan. 2014.

[81] SPIRIDON, I.; TEACA, C.-A. e BODIRLAU, R. Preparation and characterization of adipic acid-modified starch microparticles/plasticized starch composite films reinforced by lignin. Journal of Materials Science, v. 46, n. 10, p. 3241-3251, doi:10.1007/s10853-010-5210-0, 2010.

[82] SOUZA, L. A. DE. Ácido málico, ácido tartárico e ácido fumárico. Disponível em: <http://www.mundoeducacao.com/quimica/acido-malico-acido-tartarico-acidofumarico.htm>. Acesso em: 26 jan. 2014.

[83] VOLLHARDT, P. e SCHORE, N. Química Orgânica - Estrutura e Função. 6.ed. ed. Porto Alegre, RS: Bookman Editora Ltda, [S.d.].

[84] CARDOSO, M. Ácido Tartárico. Disponível em: $<$ http://www.infoescola.com/compostos-quimicos/acido-tartarico/>. Acesso em: 27 jan. 2014. 
[85] OLIVATO, J. B. et al. Mixture design applied for the study of the tartaric acid effect on starch/polyester films. Carbohydrate polymers, v. 92, n. 2, p. 1705-10, doi:10.1016/j.carbpol.2012.11.024, 2013.

[86] OLIVATO, J. B. et al. Physical and structural characterisation of starch/polyester blends with tartaric acid. Materials science \& engineering. C, Materials for biological applications, v. 39, p. 35-9, doi:10.1016/j.msec.2014.02.020, 2014.

[87] NOBREGA, M. M. et al. Biodegradable starch-based films containing saturated fatty acids: thermal, infrared and raman spectroscopic characterization. Polímeros, v. 22, n. 5, p. 467-474, doi:10.1590/S0104-14282012005000068, 2012.

[88] OLIVATO, J. B. et al. Starch/Polyester Films: Simultaneous optimisation of the properties for the production of biodegradable plastic bags. Polímeros, v. 23, n. ahead, p. 32-36, doi:10.1590/S0104-14282013005000017, 2013.

[89] OLIVATO, J. B. et al. Study of the compatibilizer effect in the properties of starch / polyester blends. Polímeros Ciência e Tecnologia, v. 23, n. 3, p. 346-351, doi:10.4322/polimeros.2013.014, 2013.

[90] MUSA, M. B. et al. Characterization and Thermomechanical Properties of Thermoplastic Potato Starch. Journal of Engineering and Technology, v. 2, n. 4, p. 9-16, 2013.

[91] ASTM D638-10 - Standard Test Method for Tensile Properties of Plastics. . West Conshohocken, PA. Estados Unidos.: [s.n.]. Disponível em: $<$ http://www.astm.org/Standards/D638.htm>, 2010.

[92] SANTAYANON, R. e WOOTTHIKANOKKHAN, J. Modification of cassava starch by using propionic anhydride and properties of the starch-blended polyester polyurethane. Carbohydrate Polymers, v. 51, n. 1, p. 17-24, doi:10.1016/S01448617(02)00109-1, 2003.

[93] HUANG, L. Y. et al. Preparation and characterization of the monoester of phthalic acid and starch. Journal of Huaqiao University, v. 25, p. 37-40, 2004.

[94] XING, G.-X. et al. Microwave-assisted Synthesis of Starch Maleate by Dry Method. Starch - Stärke, v. 58, n. 9, p. 464-467, doi:10.1002/star.200600507, 2006.

[95] FICHATALI, J. e VOORT, F. R. VAN DE. Fundamental and practical aspects of twin screw extrusion. Cereal Foods World, v. 34, n. 11, p. 921-929, 1989.

[96] LAI, S.-M.; DON, T.-M. e HUANG, Y.-C. Preparation and properties of biodegradable thermoplastic starch/poly(hydroxy butyrate) blends. Journal of Applied Polymer Science, v. 100, n. 3, p. 2371-2379, doi:10.1002/app.23085, 2006. 
[97] MENDES, F. M. Produção e Caracterização de Bioplásticos a partir deamido de batata. Universidade de São Paulo - [S.I.]. 2009.

[98] THIRÉ, R. M. S. M.; RIBEIRO, T. a. a. e ANDRADE, C. T. Effect of starch addition on compression-molded poly(3-hydroxybutyrate)/starch blends. Journal of Applied Polymer Science, v. 100, n. 6, p. 4338-4347, doi:10.1002/app.23215, 2006.

[99] LOURDIN, D.; BIZOT, H. e COLONNA, P. "Atiplasticization" in starch-glycerol film? Journal of Applied Polymer Science, v. 64, p. 1047-1053, 1997.

[100] FORSSELL, P. M. et al. Phase and glass transition behaviour of concentrated barley starch-glycerol-water mixtures, a model for thermoplastic starch.

Carbohydrate Polymers, v. 34, n. 4, p. 275-282, doi:10.1016/S01448617(97)00133-1, 1997.

[101] AVÉROUS, L.; FRINGANT, C. e MORO, L. Plasticized starch-cellulose interactions in polysaccharide composites. Polymer, v. 42, n. 15, p. 6565-6572, doi:10.1016/S0032-3861(01)00125-2, 2001.

[102] SOEST, J. J. G. VAN et al. The influence of starch molecular mass on the properties of extruded thermoplastic starch. Polymer, v. 37, n. 16, p. 3543-3552, doi:10.1016/0032-3861(96)00165-6, 1996.

[103] YURYEV, V. P.; NEMIROVSKAYA, I. E. e MASLOVA, T. D. Phase state of starch gels at different water contents. Carbohydrate Polymers, v. 26, n. 1, p. 4346, doi:10.1016/0144-8617(95)98833-3, 1995.

[104] YU, L. e CHRISTIE, G. Measurement of starch thermal transitions using differential scanning calorimetry. Carbohydrate Polymers, v. 46, n. 2, p. 179-184, doi:10.1016/S0144-8617(00)00301-5, 2001.

[105] NOEL, T. R.; RING, S. G. e WHITTAM, M. A. Glass transitions in low-moisture foods. Trends in Food Science \& Technology, v. 1, p. 62-67, doi:10.1016/09242244(90)90048-4, 1990.

[106] ORFORD, P. D. et al. Effect of water as a diluent on the glass transition behaviour of malto-oligosaccharides, amylose and amylopectin. International Journal of Biological Macromolecules, v. 11, p. 91-96, 1989.

[107] CEREDA, M. P. Propriedades Gerais do Amido. Fundação C ed. São Paulo: [s.n.], 2001.

[108] ZOBEL, H. F. Starch. Methods in carbohydrates chemistry. Academic P ed. Nova lorque: [s.n.], 1964. . 
[109] SAJIATA, M. G.; SINGHAL, R. A. e KULKARNI, P. R. Resistant Starch - A Review. Comprehensive Reviews in Food Science and Food Safety, v. 5, p. 117, 2006.

[110] BERTOLINI, A. C. et al. Starches: Characterization, Properties and Applications. Boca Raton - Florida - E.U.A.: CRC Press Taylor \& Francis Group, 2010.

[111] PARKER, R. e RING, S. G. Aspects of the Physical Chemistry of Starch. Journal of Cereal Science, v. 34, n. 1, p. 1-17, doi:10.1006/jcrs.2000.0402, 2001.

[112] CORRADINI, E. et al. Estudo comparativo de amidos termoplásticos derivados do milho com diferentes teores de amilose. Polímeros, v. 15, n. 4, p. 268-273, doi:10.1590/S0104-14282005000400011, 2005.

[113] CARMONA, V. B. Desenvolvimento de Compósitos biodegradáveis a partir de amido termoplástico e fibras vegetais. Universidade Federal de São Carlos [S.I.]. 2011.

[114] SOEST, J. J. G. VAN e ESSERS, P. Influence of Amylose-Amylopectin Ratio on Properties of Extruded Starch Plastic Sheets. Journal of Macromolecular Science, Part A, v. 34, n. 9, p. 1665-1689, doi:10.1080/10601329708010034, 1997.

[115] SOEST, J. J. G. VAN e KNOOREN, N. Influence of glycerol and water content on the structure and properties of extruded starch plastic sheets during aging.

Journal of Applied Polymer Science, v. 64, n. 7, p. 1411-1422, doi:10.1002/(SICI)1097-4628(19970516)64:7<1411::AID-APP21>3.0.CO;2-Y, 1997.

[116] KRUISKAMP, P. H. et al. The influence of plasticiser on molecular organisation in dry amylopectin measured by differential scanning calorimetry and solid state nuclear magnetic resonance spectroscopy. Journal of Industrial Microbiology \& Biotechnology, v. 26, p. 90-93, 2001.

[117] SOEST, J. J. VAN e VLIEGENTHART, J. F. Crystallinity in starch plastics: consequences for material properties. Trends in biotechnology, v. 15, n. 6, p. 20813, doi:10.1016/S0167-7799(97)01021-4, 1997.

[118] RINDLAV-WESTLING, A.; STADING, M. e GATENHOLM, P. Crystallinity and morphology in films of starch, amylose and amylopectin blends.

Biomacromolecules, v. 3, n. 1, p. 84-91, 2002.

[119] BAIL, P. LE et al. Monitoring the crystallization of amylose-lipid complexes during maize starch melting by synchrotron x-ray diffraction. Biopolymers, v. 50, n. 1, p. 99-110, doi:10.1002/(SICl)1097-0282(199907)50:1<99::AID-BIP9>3.0.CO;2-A, 1999. 
[120] RAPPENACKER, G. e ZUGENMAIER, P. Detailed refinement of the crystal structure of Vh-amylose. Carbohydrate Research, v. 89, p. 11-19, 1981.

[121] BRISSON, J.; CHANZY, H. e WINTER, W. T. The crystal and molecular structure of $\mathrm{VH}$ amylose by electron diffraction analysis. International Journal of Biological Macromolecules, v. 13, n. 1, p. 31-39, doi:10.1016/01418130(91)90007-H, 1991.

[122] ZOBEL, H. F.; FRENCH, A. D. e HINKLE, M. E. X-Ray diffraction of oriented amylose fibers. II. Structure of V amyloses. Biopolymers, v. 5, n. 9, p. 837-845, doi:10.1002/bip.1967.360050906, 1967.

[123] SOEST, J. J. G. VAN et al. Crystallinity in starch bioplastics. Industrial Crops and Products, v. 5, n. 1, p. 11-22, doi:10.1016/0926-6690(95)00048-8, 1996.

[124] YAMASHIDA, Y. e MONOBE, K. Single crystals of amylose $V$ complexes. III. Crystals with 8-I helical configuration. Journal Polymer Science Part A2, v. 4, p. 1471-1481, 1966.

[125] HULLEMAN, S. H. D. et al. Origins of B-type crystallinity in glycerol-plasticised, compression- moulded potato starches. Carbohydrate Polymers, v. 39, p. 351-360, 1999.

[126] SMITS, a. L. . et al. The influence of various small plasticisers and maltooligosaccharides on the retrogradation of (partly) gelatinised starch. Carbohydrate Polymers, v. 51, n. 4, p. 417-424, doi:10.1016/S0144-8617(02)00206-0, 2003.

[127] THIRÉ, R. M. S. M.; ANDRADE, C. T. e SIMÃO, R. A. Effect of aging on the microstructure of plasticized cornstarch films. Polímeros: Ciência e Tecnologia, $v$. 15, p. 130-133, 2005.

[128] AVÉROUS, L. e AVE, L. Biodegradable Multiphase Systems Based on Plasticized Starch: A Review. Journal of Macromolecular Science, Part C:

Polymer Reviews, v. 44, n. 3, p. 231-274, doi:10.1081/MC-200029326, 2004.

[129] SHANKS, R. e KONG, I. Thermoplastic Starch. In: EL-SONBATI, A. Z. (Ed.). . Thermoplastic Elastomers. [S.I.]: InTech, 2011. p. 95-116.

[130] LOURDIN, D. et al. Structural relaxation and physical ageing of starchy materials. Carbohydrate Research, v. 337, n. 9, p. 827-833, doi:10.1016/S00086215(02)00064-2, 2002.

[131] SHOGREN, R. L. Effect of moisture content on the melting and subsequent physical aging of cornstarch. Carbohydrate Polymers, v. 19, n. 2, p. 83-90, doi:10.1016/0144-8617(92)90117-9, 1992. 
[132] BORDE, B. et al. Calorimetric analysis of the structural relaxation in partially hydrated amorphous polysaccharides. II. Phenomenological study of physical ageing. Carbohydrate Polymers, v. 48, n. 2, p. 111-123, doi:10.1016/S01448617(01)00218-1, 2002.

[133] CHUNG, H.-J. e LIM, S.-T. Physical aging of glassy normal and waxy rice starches: effect of aging time on glass transition and enthalpy relaxation.

Carbohydrate Polymers, v. 17, n. 6, p. 855-861, doi:10.1016/S0268005X(03)00106-1, 2003.

[134] SOEST, J. J. G. J. G. VAN et al. Changes in the mechanical properties of thermoplastic potato starch in relation with changes in B-type crystallinity.

Carbohydrate Polymers, v. 29, n. 1996, p. 225-232, 1994.

[135] FORSSELL, P. Ageing of rubbery thermoplastic barley and oat starches.

Carbohydrate Polymers, v. 39, n. 1, p. 43-51, doi:10.1016/S0144-8617(98)001283, 1999.

[136] SHI, R. et al. Ageing of soft thermoplastic starch with high glycerol content. Journal of Applied Polymer Science, v. 103, n. 1, p. 574-586, doi:10.1002/app.25193, 2007.

[137] SOEST, J. J. G. VAN; WIT, D. DE e VLIEGENTHART, J. F. G. Mechanical properties of thermoplastic waxy maize starch. Journal of Applied Polymer Science, v. 61, n. 11, p. 1927-1937, doi:10.1002/(SICl)10974628(19960912)61:11<1927::AID-APP7>3.0.CO;2-L, 1996.

[138] STRUIK, L. C. E. Physical Aging in Amorphous Polymers and Other Materials. Technische Hogeschool Delft - Universidade Técnica de Delft - [S.I.]. 1978.

[139] STRUIK, L. C. E. Physical Aging in Plastics and Other Glassy Materials. Polymer Engeneering and Science, v. 17, n. 3, p. 165 - 173, 1977.

[140] COLONNA, P. e BULEON, A. Thermal transitions of starches. In: BERTOLINI, A. C. (Ed.). . Starches: Characterization, Properties, and Applications. Nova lorque: CRC Press Taylor \& Francis Group, 2010. p. 71-102.

[141] HOSENEY, R. C.; ZELEZNAK, K. e LAI, C. S. Wheat Gluten: A Glassy Polymer. Cereal Chemistry, v. 63, p. 285-286, 1986.

[142] SAUVAGEOT, F. e BLOND, G. EFFECT OF WATER ACTIVITY ON CRISPNESS OF BREAKFAST CEREALS. Journal of Texture Studies, v. 22, n. 4, p. 423-442, doi:10.1111/j.1745-4603.1991.tb00502.x, 1991. 
[143] KALICHEVSKY, M. T. T. et al. The glass transition of amylopectin measured by DSC, DMTA and NMR. Carbohydrate Polymers, v. 18, n. 2, p. 77-88, doi:10.1016/0144-8617(92)90129-E, 1992.

[144] BAIL, P. LE; BIZOT, H. e BULÉON, A. "B" to "A" type phase transition in short amylose chains. Carbohydrate Polymers, v. 21, n. 2-3, p. 99-104, doi:10.1016/0144-8617(93)90005-O, 1993.

[145] SEOW, C. C. e TEO, C. H. Annealing of Granular Rice Starches Interpretation of the Effect on Phase Transitions Associated with Gelatinization. Starch - Stärke, v. 45, n. 10, p. 345-351, doi:10.1002/star.19930451004, 1993.

[146] CHUNG, H.-J. e LIM, S.-T. Physical aging of glassy normal and waxy rice starches: thermal and mechanical characterization. Carbohydrate Polymers, v. 57, n. 1, p. 15-21, doi:10.1016/j.carbpol.2004.01.010, 2004.

[147] THIRÉ, R. M. S. M. et al. Investigation of humidity-induced microstructural changes in cornstarch films by atomic force microscopy. Acta Microscópica, v. 12, p. 96-99, 2003.

[148] MA, X. e YU, J. The Effects of Plasticizers Containing Amide Groups on the Properties of Thermoplastic Starch. STARCH - STARKE, v. 56, n. 11, p. 545-551, doi:10.1002/star.200300256, 2004.

[149] MONDRAGÓN, M.; ARROYO, K. e ROMERO-GARCÍA, J. Biocomposites of thermoplastic starch with surfactant. Carbohydrate Polymers, v. 74, n. 2, p. 201208, doi:10.1016/j.carbpol.2008.02.004, 2008.

[150] KUUTTI, L. et al. AFM in studies of thermoplastic starches during ageing.

Carbohydrate Polymers, v. 37, n. 1, p. 7-12, doi:10.1016/S0144-8617(98)00042-3, 1998.

[151] ZHANG, Y. e HAN, J. H. Plasticization of Pea Starch Films with Monosaccharides and Polyols. Journal of Food Science, v. 71, n. 6, p. E253-E261, doi:10.1111/j.1750-3841.2006.00075.x, 2006.

[152] GOODFELLOW, B. J. e WILSON, R. H. A fourier transform IR study of the gelation of amylose and amylopectin. Biopolymers, v. 30, n. 13-14, p. 1183-1189, doi:10.1002/bip.360301304, 1990.

[153] WILSON, R. H. et al. A fourier-transform infrared study of the gelation and retrogradation of waxy-maize starch. Carbohydrate Research, v. 166, n. 1, p. 162165, doi:10.1016/0008-6215(87)80053-8, 1987.

[154] SOEST, J. J. G. VAN et al. Short-range structure in (partially) crystalline potato starch determined with attenuated total reflectance Fourier-transform IR 
spectroscopy. Carbohydrate Research, v. 279, p. 201-214, doi:10.1016/00086215(95)00270-7, 1995.

[155] PUSHPADASS, H. a. e HANNA, M. a. Age-Induced Changes in the Microstructure and Selected Properties of Extruded Starch Films Plasticized with Glycerol and Stearic Acid. Industrial \& Engineering Chemistry Research, v. 48, n. 18, p. 8457-8463, doi:10.1021/ie801922z, 2009.

[156] SMITS, A. L. M. et al. Ageing of Starch Based Systems as Observed with FT-IR and Solid State NMR Spectroscopy. Starch/Starke, v. 39, n. 1965, p. 478-483, 1998.

[157] CHUNG, H.-J. e LIM, S.-T. Physical Aging of Amorphous Starches (A Review). Starch - Stärke, v. 58, n. 12, p. 599-610, doi:10.1002/star.200600547, 2006.

[158] VODOVOTZ, Y. e CHINACHOTI, P. Glassy-Rubbery Transition and Recrystallization during Aging of Wheat Starch Gels. Journal of Agricultural and Food Chemistry, v. 46, n. 2, p. 446-453, doi:10.1021/jf970631l, 1998.

[159] SOEST, J. J. G. VAN et al. Retrogradation of Potato Starch as Studied by Fourier Transform Infrared Spectroscopy. Starch - Stärke, v. 46, n. 12, p. 453-457, doi:10.1002/star.19940461202, 1994.

[160] SOEST, J. J. G. VAN et al. The influence of glycerol on structural changes in waxy maize starch as studied by Fourier transform infra-red spectroscopy. Polymer, v. 35, n. 22, p. 4722-4727, doi:10.1016/0032-3861(94)90724-2, 1994.

[161] UTRACKI, L. A. Polymer Blends Handbook. Springer, Netherlands:

Dordrecht, 2003.

[162] ATWELL, W. A. et al. The terminology and methodology associated with basic starch phenomena. Cereal Foods World, v. 33, n. 3, p. 306-311, 1988.

[163] VEENSTRA, $\mathrm{H}$. et al. Co-continuous morphologies in polymer blends with SEBS block copolymers. Polymer, v. 40, n. 24, p. 6661-6672, doi:10.1016/S00323861(98)00875-1, 1999.

[164] BASSANI, A.; PESSAN, L. A. e HAGE, E. Toughening of polypropylene with styrene/ethylene-butylene/styrene tri-block copolymer: Effects of mixing condition and elastomer content. Journal of Applied Polymer Science, v. 82, n. 9, p. 21852193, doi:10.1002/app.2066, 2001.

[165] SUNDARARAJ, U. e MACOSKO, C. W. Drop Breakup and Coalescence in Polymer Blends: The Effects of Concentration and Compatibilization.

Macromolecules, v. 28, n. 8, p. 2647-2657, doi:10.1021/ma00112a009, 1995. 
[166] ABREU, F. O. M. d. S. Blendas de Polipropileno com Elastômeros Termoplásticos tipo SBS e SEBS. Universidade Federal do Rio Grande do Sul UFRGS - [S.I.]. 2004.

[167] WILLEMSE, R. C. et al. Co-continuous morphologies in polymer blends: a new model. Polymer, v. 39, n. 24, p. 5879-5887, doi:10.1016/S0032-3861(97)10200-2, 1998.

[168] LEE, M.-P.; HILTNER, A. e BAER, E. Phase morphology of injection-moulded polycarbonate/acrylonitrile-butadiene-styrene blends. Polymer, v. 33, n. 4, p. 685697, doi:10.1016/0032-3861(92)90323-O, 1992.

[169] DEMARQUETTE, N. R. Tensão Interfacial em Blendas Poliméricas. Universidade de São Paulo - [S.I.]. 1999.

[170] ADAMSON, A. Physical Chemistry of Surfaces. New York: Wiliey Interscience, 1996.

[171] SOUZA, A. M. C. Avaliação da Tensão Interfacial entre Poliolefinas. Universidade de São Paulo - [S.I.]. 2002.

[172] YEE, M. Estudo da Influência da adição do Copolímero estatístico P(S-coMMA) no Comportamento Reológico da mistura Polimérica PMMA/PS. Universidade de São Paulo - [S.I.]. 2003.

[173] WU, S. H. Formation of dispersed phase in incompatible polymer blends: interfacial and rheological effects. Polymer Engineering and Science, v. 27, n. 5, p. 335-343, 1987.

[174] BIZI, C. M. P. Efeito das Condições de Processamento e da Adição de Borracha Trans-Polioctenileno nas Propriedades de Blendas de Borraca Natural/Estireno Butadieno. Universidade de São Paulo - [S.I.]. 2007.

[175] MACAUBAS, P. H. e DEMARQUETTE, N. R. Morphologies and Interfacial Tensions of Immiscible polypropylene/polyestirene blends modified with triblock copolymers. Polymer, v. 42, p. 2453, 2001.

[176] WU, S. Formation of dispersed phase in incompatible polymers blend: interfacial and rheological effects. Polymer Engineering \& Science, v. 7, p. 335, 1987.

[177] WILLEMSE, R. . et al. Co-continuous morphologies in polymer blends: the influence of the interfacial tension. Polymer, v. 40, n. 4, p. 827-834, doi:10.1016/S0032-3861(98)00307-3, 1999.

[178] WILLEMSE, R. C. et al. Tensile moduli of co-continuous polymer blends. v. 40, n. September 1998, p. 6645-6650, 1999. 
[179] PERNOT, H. et al. Design and properties of co-continuous nanostructured polymers by reactive blending. Nature materials, v. 1 , n. 1, p. 54-8, doi:10.1038/nmat711, 2002.

[180] GALLOWAY, J. a. e MACOSKO, C. W. Comparison of methods for the detection of cocontinuity in poly(ethylene oxide)/polystyrene blends. Polymer

Engineering and Science, v. 44, n. 4, p. 714-727, doi:10.1002/pen.20064, 2004.

[181] WILLEMSE, R. C. Co-continuous morphologies in polymer blends: stability. Polymer, v. 40, n. 8, p. 2175-2178, doi:10.1016/S0032-3861(98)00430-3, 1999.

[182] MIRANDA, V. R. e CARVALHO, A. J. F. Blendas Compatíveis de Amido Termoplástico e Polietileno de Baixa Densidade Compatibilizadas com Ácido Cítrico. Polimeros, v. 21, n. 5, p. 352-360, 2011.

[183] SCHWACH, E. e AVÉROUS, L. No Title. Polymer International, v. 53, p. 2115, doi:10.1002/pi.1636, 2004.

[184] YU, L.; DEAN, K. e LI, L. No Title. Progress in Polymer Science, v. 31, p. 576, 2006.

[185] WILLETT, J. L. No Title. Journal of Applied Polymer Science, v. 54, p. 1685, doi:10.1002/app.1994.070541112, 1994.

[186] WANG, X. L.; YANG, K. K. e WANG, Y. Z. No Title. Journal of Macromolecular Science Part C, v. C43, p. 385, 2003.

[187] AMASS, W.; AMASS, A. e TIGHE, B. No Title. Polymer International, v. 47, p. 89, doi:10.1002/(SICl)1097-0126(1998100)47:2\%3C89::AID-PI86\%3E3.0.CO;2-F, 1998.

[188] SARAZIN, P. et al. Binary and ternary blends of polylactide, polycaprolactone and thermoplastic starch. Polymer, v. 49, n. 2, p. 599-609, doi:10.1016/j.polymer.2007.11.029, 2008.

[189] SCOTT, G. e WILES, D. M. Programmed-Life Plastics from Polyolefins: A New Look at Sustainability †. Biomacromolecules, v. 2, n. 3, p. 615-622, doi:10.1021/bm010099h, 2001.

[190] SCOTT, G. Photo-biodegradable plastics: Their role in the protection of the environment. Polymer Degradation and Stability, v. 29, n. 1, p. 135-154, doi:10.1016/0141-3910(90)90026-4, 1990.

[191] GRIFFIN, G. J. L. Gelatinised Starch Products. Chemistry and Technology of Biodegradable Polymers. London: Blackie Academic \& Professional, 1994. . 
[192] BIKIARIS, D. e PANAYIOTOU, C. LDPE/starch blends compatibilized with PEg-MA copolymers. Journal of Applied Polymer Science, v. 70, n. 8, p. 1503-1521, doi:10.1002/(SICI)1097-4628(19981121)70:8<1503::AID-APP9>3.0.CO;2-\#, 1998.

[193] SAILAJA, R. R. N. e CHANDRA, M. No Title. Journal Polymer Material, v. 17, p. $165,2000$.

[194] SAILAJA, R. R. N. e CHANDA, M. Use of poly(ethylene-co-vinyl alcohol) as compatibilizer in LDPE/thermoplastic tapioca starch blends. Journal of Applied Polymer Science, v. 86, n. 12, p. 3126-3134, doi:10.1002/app.11340, 2002.

[195] SAILAJA, R.; REDDY, A. P. e CHANDA, M. Effect of epoxy functionalized compatibilizer on the mechanical properties of low-density polyethylene/plasticized tapioca starch blends. Polymer International, v. 50, n. 12, p. 1352-1359, doi:10.1002/pi.787, 2001.

[196] SAILAJA, R. Mechanical properties of esterified tapioca starch-LDPE blends using LDPE-co-glycidyl methacrylate as compatibilizer. Polymer International, v. 54, n. 2, p. 286-296, doi:10.1002/pi.1669, 2005.

[197] MIRANDA, V. R. e CARVALHO, ANTONIO, J. F. Blendas Compatíveis de Amido Termoplástico e Polietileno de Baixa Densidade Compatibizadas com ácido Cítrico. Polímeros, v. 21, p. 353-360, 2011.

[198] YU, L. et al. Effect of compatibilizer distribution on the blends of starch/biodegradable polyesters. Journal of Applied Polymer Science, v. 103, n. 2, p. 812-818, doi:10.1002/app.25184, 2007.

[199] CARVALHO, G. M. X. De et al. Obtenção de compósitos de resíduos de ardósia e polipropileno. Polímeros, v. 17, n. 2, p. 98-103, doi:10.1590/S0104$14282007000200008,2007$.

[200] SHUJUN, W.; JIUGAO, Y. e JINGLIN, Y. Preparation and characterization of compatible thermoplastic starch/polyethylene blends. Polymer Degradation and Stability, v. 87, n. 3, p. 395-401, doi:10.1016/j.polymdegradstab.2004.08.012, 2005. 